Andrews University

Digital Commons @ Andrews University

2017

\title{
Toward A Model Of The Ontology Of The Divine Indwelling Of Humans: A Comparative Study Of John Wesley And John Cobb
}

Cory Wetterlin

Andrews University, wetterli@andrews.edu

Follow this and additional works at: https://digitalcommons.andrews.edu/dissertations

Part of the Religious Thought, Theology and Philosophy of Religion Commons

\section{Recommended Citation}

Wetterlin, Cory, "Toward A Model Of The Ontology Of The Divine Indwelling Of Humans: A Comparative Study Of John Wesley And John Cobb" (2017). Dissertations. 1647.

https://digitalcommons.andrews.edu/dissertations/1647

https://dx.doi.org/10.32597/dissertations/1647

This Dissertation is brought to you for free and open access by the Graduate Research at Digital Commons @ Andrews University. It has been accepted for inclusion in Dissertations by an authorized administrator of Digital Commons@ Andrews University. For more information, please contact repository@andrews.edu. 


\section{Andrews University}

Digital Commons@Andrews University

2018

Toward a Model of the Ontology of the Divine Indwelling of Humans: A Comparative Study of John Wesley and John Cobb

Cory Wetterlin 



\section{ABSTRACT}

\section{TOWARD A MODEL OF THE ONTOLOGY OF DIVINE-HUMAN INDWELLING: A COMPARATIVE STUDY \\ OF JOHN WESLEY AND JOHN COBB}

Cory Wetterlin

Adviser: Martin Hanna 


\title{
ABSTRACT OF GRADUATE STUDENT RESEARCH
}

Dissertation

\author{
Andrews University \\ Adventist Theological Seminary
}

\section{Title: TOWARD A MODEL OF THE ONTOLOGY OF DIVINE-HUMAN INDWELLING: A COMPARATIVE STUDY OF JOHN WESLEY AND JOHN COBB}

Name of researcher: Cory D. Wetterlin

Name and degree of faculty adviser: Martin Hanna, Ph.D

Date completed: November 2017

\section{Problem and Purpose}

This dissertation addresses the problem of the conflicting views of the ontology of divine-human indwelling that have been manifested in the historical discussion and specifically demonstrated in the models proposed by John Wesley and John Cobb. The purpose of this research is to survey and analyze the writings of Wesley and Cobb, in order to present their models of the ontological nature of the divine-human indwelling. Their models are evaluated on the basis of their interpretations of Romans 6-8 compared with each other and representative current scholarship.

\section{Method}

The method for this research includes the following: Chapter 1 consists of an 
introduction and historical background. Chapters 2 and 3 present a survey and analysis of the writings of Wesley and Cobb respectively, in order to describe their models of divinehuman indwelling. This is done using the following three categories: ontology of God, ontology of humanity, and ontology of divine-human indwelling. In order to evaluate whether these models of divine-human indwelling are biblically adequate, chapter 4 compares and contrasts Wesley's and Cobb's interpretations of Romans 6-8 in light of current representative scholarship. In Chapter 5, following the summary and conclusions regarding Wesley's and Cobb's models, implications are identified for moving towards a more biblical model for the nature of divine-human indwelling.

\section{Conclusions}

The specific definition of ontological indwelling for this dissertation is the interpenetration/intermingling of the divine and human beings/realities. John Wesley taught an ontological indwelling of the Holy Spirit following the classical theological tradition, in which the timeless eternal divine being/reality is united with the timeless being/reality of the human soul. The Holy Spirit is then the formal and efficient cause of transforming the human being/reality. John Cobb teaches a panentheistic ontological indwelling based on non-substantive process philosophy, which inclusively intermingles the human being/reality within the being/reality of the divine. Each human individual has the opportunity to respond to the primordial creative will of God, thus being transformed by that response and become part of the consequential will of God.

An evaluation of Wesley's and Cobb's understandings of the ontological nature of divine-human indwelling by representative scholars using the exegetical lens of Romans 6-8 reveals some affirmations and some challenges for these two systems. The primary 
challenge for Wesley and Cobb is a rejection by representative scholars of ontological indwelling defined as the interpenetration/intermingling of divine and human beings/realities. This study then calls for further research to be done on other conceptions of divine-human indwelling in relation to biblical teaching on the subject. 


\title{
Andrews University \\ Seventh-day Adventist Theological Seminary
}

\section{TOWARD A MODEL OF THE ONTOLOGY OF DIVINE-HUMAN INDWELLING: A COMPARATIVE STUDY OF JOHN WESLEY AND JOHN COBB}

\author{
A Dissertation \\ Presented in Partial Fulfillment \\ of the Requirements for the Degree \\ Doctor of Philosophy
}

by

Cory Wetterlin

November 2017 
(OCopyright by Cory D. Wetterlin 2017 All Rights Reserved 


\title{
TOWARD A MODEL OF THE ONTOLOGY OF DIVINE-HUMAN INDWELLING: A COMPARATIVE STUDY \\ OF JOHN WESLEY AND JOHN COBB
}

\author{
A dissertation \\ presented in partial fulfillment \\ of the requirements for the degree \\ Doctor of Philosophy
}

by

Cory Wetterlin

APPROVAL BY THE COMMITTEE:

Faculty Adviser, Martin Hanna

Associate Professor of Theology and Christian Philosophy

John C. Peckham

Associate Professor of Theology and Christian Philosophy

Ranko Stefanovic Professor of New Testament
Director of $\mathrm{PhD} / \mathrm{ThD}$ Religion Program Thomas Shepherd

Dean, SDA Theological Seminary

Jiři Moskala

Date approved 


\section{Dedication:}

This work is dedicated to my loving wife Laura, my daughter Lorelai, and the rest of my family for their loving support throughout this Ph.D. process. I could not have done this without all of you. 


\section{TABLE OF CONTENTS}

LIST OF ABBREVIATIONS ................................................................ vii

Chapter

1. INTRODUCTION AND HISTORICAL BACKGROUND ........................... 1

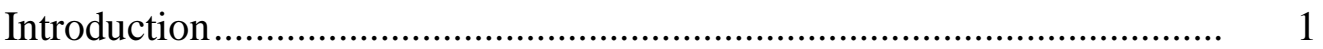

Historical Background ....................................................................... 2

From Greek Philosophy to John Wesley .......................................... 2

From John Wesley to John Cobb ........................................................ 16

Statement of the Problem..................................................................... 25

Purpose of the Research................................................................. 26

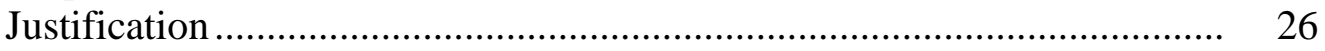

Method ............................................................................................... 27

Theoretical Framework ....................................................................... 28

Scope and Deliminations ............................................................. 32

2. JOHN WESLEY'S UNDERSTANDING OF THE ONTOLOGICAL NATURE OF DIVINE-HUMAN INDWELLING .................................... 34

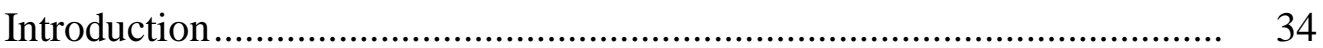

John Wesley's Biographical Sketch and Theological Method............ 34

Wesley's Spriritual Experience .................................................. 35

Wesley's Respect for Tradition ................................................ 36

Wesley's Use of Reason ............................................................ 42

Summary: Scripture Through Wesley's Filter ........................... 43

The Ontology of God ......................................................................... 44

God's Eternity and Omnipresence................................................... 45

Distinct from Creation .................................................................. 49

God as Trinity ........................................................................ 50

Wesley's Christology ......................................................... 52

Wesley's Pneumatology ......................................................... 53

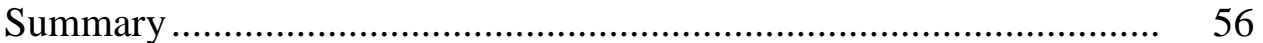

The Ontology of Humanity .................................................................. 57

Wesley's Dualistic Ontology of Humanity ...................................... 57

Wesley's View of the Immortal Soul ............................................... 60

Wesley's Conception of the Image of God ..................................... 63

Wesley's View of Spiritual Senses................................................... 67

Summary and Conclusion ................................................................. 67 
Ontological Nature of Divine-Human Indwelling .................................... 69

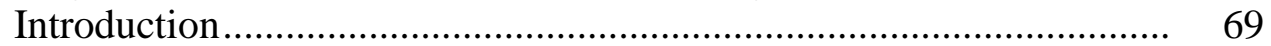

Wesley's Indwelling Trinity ........................................................... $\quad 70$

Unique Presence in the Justified ......................................................... 71

Possession and Filling .................................................................... 73

Mutual Indwelling ..................................................................... 74

Inspiration/Breathing ……............................................................ 76

Eschatological End........................................................................ 77

Knowledge and Love ..................................................................... 79

Happiness .................................................................................. 81

Renewal of the Image of God ........................................................ 82

Holy Spirit and The Kingdom.......................................................... 84

Witness of the Spirit...................................................................... 85

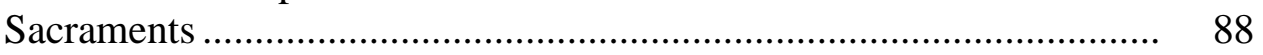

Summary and Conclusion ................................................................... $\quad 89$

3. JOHN B. COBB JR'S UNDERSTANDING OF THE ONTOLOGICAL NATURE OF DIVIVE-HUMAN INDWELLING........................................ 92

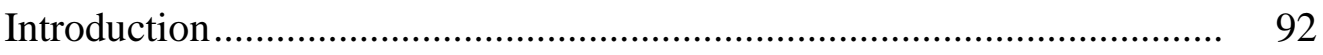

John B. Cobb Jr.'s Biographical Sketc and Theological Method.......... 92

Ontology of God ................................................................................ 99

Experience-based Reality ............................................................... 99

Panentheism ............................................................................ 104

Trinity of Natures.......................................................................... 106

God as Lure - Primordial Nature (Logos) ..................................... 112

Consequent Nature - Peace (Spirit)................................................ 117

God's Liberating Power ................................................................ 121

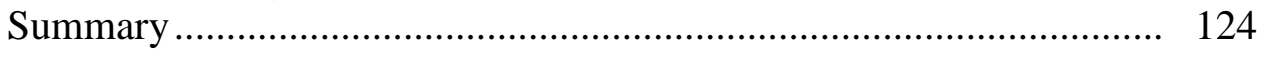

Ontology of Humanity ………………………………………….... 126

Occasions of Experience............................................................. 126

Dominant Occasion.................................................................... 128

The Human Spirit.......................................................................... 132

Spirit-Centered Wholeness ............................................................... 134

Corporate Personhood ..................................................................... 137

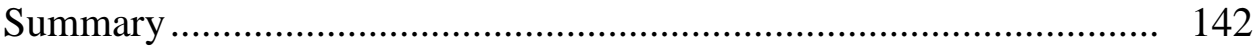

Ontological Nature of Divine-Human Indwelling .................................... 142

Transcendence and Immanence ......................................................... 145

Participation in Being .................................................................. 146

In Christ - Incarnation of the Logos.................................................. 149

Peace and Kingdom - Consequent Nature of God ............................... 153

Possession ............................................................................... 155

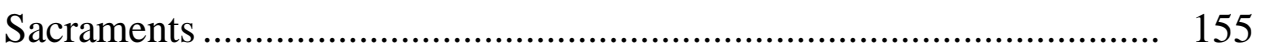

Spirit-Centered Wholeness …………………………………........ 157

Summary and Conclusion ................................................................. 158 
4. COMPARISON AND CONTRAST OF JOHN WESLEY AND JOHN B. COBB JR. AND THEIR UNDERSTANDINGS OF THE ONTOLOGICAL NATURE OF DIVINE-HUMAN INDWELLING

Introduction .............................................................................. 161

Romans Chapter Six: Baptism and Participation in Christ ..................... 163

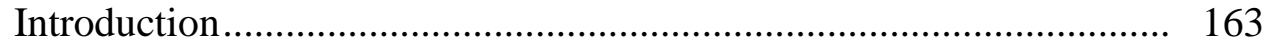

John Wesley: Ingrafted into Christ ................................................ 164

John B. Cobb Jr.: Baptism as Participation..................................... 170

Comparison of Wesley and Cobb ............................................... 175

Evaluation of Wesley and Cobb ................................................ 178

Romans Chapter 8:1-17-Life in the Spirit.......................................... 188

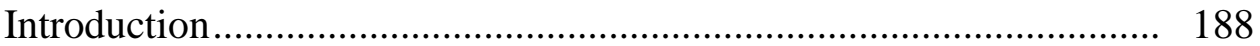

Wesley: A Life Directed by the Holy Spirit .................................. 188

Cobb: Mutual Participation in Being .............................................. 190

Comparison of Wesley and Cobb ................................................ 193

Evaluation of Wesley and Cobb ................................................... 195

Romans 8:18-22: Cosmic Deliverance ................................................ 205

Introduction....................................................................... 205

Wesley: On The General Deliverance .......................................... 206

Cobb: Universal Participation in the Glory of God's Presence............ 209

Wesley and Cobb Compared .......................................................... 212

Evaluation of Wesley and Cobb .................................................. 213

Summary and Conclusion .......................................................... 217

5. SUMMARY, CONCLUSIONS, AND IMPLICATIONS FOR FURTHER

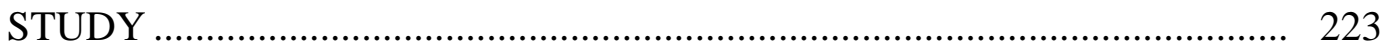

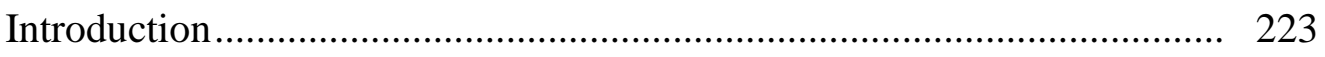

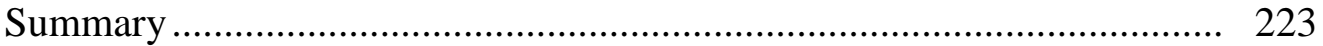

Chapter 1: Historical Background ............................................... 223

Chapter 2: John Wesley ........................................................... 225

Chapter 3: John B. Cobb Jr........................................................ 227

Chapter 4: Comparison and Evaluation of Wesley and Cobb ............. 231

Conclusions ................................................................................... 236

Similarities Between Wesley and Cobb......................................... 236

Differences Between Wesley and Cobb ........................................ 237

Evaluation of Wesley and Cobb ............................................... 239

Implications for Further Study ..................................................... 242

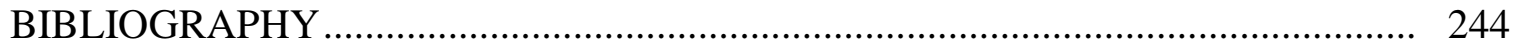




\section{LIST OF ABBREVIATIONS}

NT

OT

TDNT

TWOT
New Testament

Old Testament

Theological Dictionary of the New Testament. Edited by G. Kittel and G. Friedrich. Translated by G. W. Bromily. 10 vols. Grand Rapids, 19641976

Theological Wordbook of the Old Testament. Harris, R. Laird, Gleason L. Archer, and Bruce K. Waltke. Chicago: Moody Press, 1980. 


\section{CHAPTER 1}

\section{INTRODUCTION AND HISTORICAL BACKGROUND}

\section{Introduction}

This dissertation investigates the theological models of the ontological nature of divine-human indwelling developed by John Wesley and John B. Cobb Jr. ${ }^{1}$ The reason for the comparison of these two theologians is two-fold. First, Wesley presents a theistic model while Cobb presents a panentheistic model. Wesley represents a form of the classical substantial-union understanding of the ontological nature of the divine-human indwelling, while Cobb represents a more experiential all-inclusive understanding of the ontological nature of the divine-human indwelling. Second, Cobb's theological background includes Wesley. This presents the opportunity for exploring a progressive theological development as well as some direct usage of Wesley by a more contemporary voice. The historical background will therefore be presented in two parts: first, the historical background leading up to Wesley; second, the historical background between the times of Wesley and Cobb.

\section{Historical Background}

The first section of the historical background will briefly trace the streams of thought, which emphasize the more transcendent interpretation versus the more

\footnotetext{
${ }^{1}$ The reason for the using the terminology "divine-human indwelling" rather than the traditional indwelling of the Holy Spirit, for example, is needed in this dissertation because of the panentheistic way in which John Cobb approaches the subject. The panentheistic view is one of mutual indwelling and the personhood of the Holy Spirit is also in question in process theology, therefore, the need to use divine in general rather than personal. Thus, the use of divine-human indwelling.
} 
immanent interpretation regarding the ontological nature of the divine-human indwelling. Beginning with Greek Philosophy, it will move on to the church fathers, the scholastics through Thomas Aquinas, and the lead up to Wesley himself (whose primary influence in his understanding of spirituality was Macarius). ${ }^{2}$ The second section will deal with the development of the theological thinking concerning the ontological nature of the divinehuman indwelling from John Wesley, through modern theology, and finishing with John Cobb.

\section{From Greek Philosophy to John Wesley}

In the classical transcendent system of thought, the Greek philosophers are interpreted to have proposed a God-world relationship, which was done in such a way that the divine was separated from creation. The dualism of Plato points to an ultimate good contained in the timeless world of ideas, which is incapable of interaction with the

\footnotetext{
${ }^{2}$ Hoo-Jung Lee, "The Doctrine of New Creation in the Theology of John Wesley" (Ph.D., Emory University, 1991).
} 
material world. ${ }^{3}$ Some have interpreted the ultimate good as Plato's equivalent of God. ${ }^{4}$

Through his substance ontology, Aristotle removes the dualistic levels of reality and

places the dualism within a single level of reality. ${ }^{5}$ Instead of the idea of ultimate good,

Aristotle proposes an unmoved mover who is the final cause. All beings seek to be like

\begin{abstract}
${ }^{3}$ Both classical theism and some forms of panentheistic theism have their roots in Greek Philosophy: "Broadly speaking, the difference between classical theism and panentheism is what each appropriated from Plato and Neoplatonism. To articulate the biblical doctrine of creation, the Christian church fathers adapted Plato's eternal transcendent God, the Father, Mind, and Craftsman, who is wholly other than the world he makes. They modified it to fit the doctrine of the Trinity: the Father, the Son as the Word including the Ideas, and the Holy Spirit as Creator but not as World-Soul. The panentheist tradition found two options in Plato. Most panentheists followed Plotinus, the Neoplatonist who reframed Plato $\mathrm{s}$ theological cosmology as a divine hierarchy, a Great Chain of Being: The One God generates the Mind, which generates the World-Soul, which generates the world, which exists in the World-Soul, which exists in the Mind, which exists in the One. Neoplatonism is panentheistic because everything exists within God in a series of concentric emanations. In Neoplatonism God is both the wholly transcendent One, the Mind, and the World-Soul immanent in the world. Thus the Divine is both transcendent and immanent, eternal and temporal, changeless and changing, and so forth. This notion of Deity becomes the panentheist tradition that is still expressed by the process theologians Whitehead and Hartshorne in their concept of dipolarity that God has two natures. This tradition has an unbroken history from Plato to Whitehead, who once observed that the history of Western philosophy is a series of footnotes to Plato. He could have made the same comment about theology. Much panentheism carries on the transcendent-immanent theology of Neoplatonism." John W. Cooper, Panentheism, The Other God of the Philosophers: From Plato to the Present (Grand Rapids, MI: Baker Academic, 2006), 18-19. See Plato's allegory of the cave: Plato, "Plato's Republic," (http://www.gutenberg.org/files/1497/1497-h/1497-h.htm: Gutenberb EBook, 2008) (accessed March 24, 2015). See also John C. Peckham, "The Concept of Divine Love in the Context of the GodWorld Relationship" (Dissertation, Andrews University Seventh-day Adventist Theological Seminary, 2012), 48.
\end{abstract}

4 'In Timaeus Plato identifies 'the God' as the Maker of the world, even designating him 'Father.' This Demiurge makes the world according to the Ideal as an artisan makes an object according to a model. Republic (597b) affirms the same view, that God is like a Craftsman, and it adds that he is the source of the Forms, a role that also belongs to the Good. This shared role implies the identity of the Creator God and the Good. Additionally, in Philebus (30c) God is the Mind or divine Reason [Nous] that orders the universe. This association takes us back to Timaeus, where ordering the universe is the job of the Demiurge, whose artifacts are likewise said to be 'the works of Mind/Reason'." Cooper, Panentheism, 37. Cf: Plato, "Timaeus," in The Dialogues of Plato, ed. Robert Maynard Hutchins, Great Books of the Western World (Chicago: Encyclopaedia Britanica, 1952); Plato, "Philebus." Plotinus, who is considered the father of NeoPlatonism, describes the ultimate good as the one, which is the cause of all form and the basis of being intellectually. The intellect is the instrument of the one externally represented in the desire of the soul, which is then externally expressed in the body. As long as the intellect and returning to the one remains the focus of the soul, rather than attachment to the body, the individual refrains from evil. Lloyd Gerson, "Plotinus", The Stanford Encyclopedia of Philosophy <http://plato.stanford.edu/archives/sum2014/entries/plotinus/> (accessed March 31 2015).

${ }^{5}$ Aristotle requires the composite nature of ontological reality of matter or sensual substance with form in order for actual being. Aristotle, "Metaphysics", Harvard University Press http://www.perseus.tufts.edu/hopper/text?doc=Perseus\%3Atext\%3A1999.01.0052\%3Abook\%3D7\%3Asect ion\%3D1028a (accessed March 30 2015), 7.1028a. See also: Peckham, "Concept of Divine Love", 60. 
the final cause. It is their teleological goal. The potential in each individual moves him or her towards the uncreated act, which can be interpreted as God. The ontological participation for the human person to unite with God in this system of thought is only the potential within each individual, which strives to be like the ultimate perfect being. Although Aristotle brings Plato's two realities into one, he still maintains a transcendent distance between the divine and the rest of the cosmos. ${ }^{6}$

In order to find complete immanence of divine presence in the cosmos, within Greek philosophy, one must turn to the Stoics, who may offer the clearest picture of the union of each individual part with the substance of the cosmos. The universe is seen as a living being and God is the soul. The two are understood as one substance. ${ }^{7}$ The Stoics view the Pneuma as the force or energy, which both pervades the world as well as surrounds the world in such a way that it holds the world together. While the Stoics seem to accept Plato's creation account, there is a particular difference in that the divine creator is a part of the world-soul for the Stoics, while the divine creator remains two degrees separated from the world-soul in Plato. ${ }^{8}$ The stoics have been categorized by some as

\footnotetext{
${ }^{6}$ Peckham, "Concept of Divine Love", 70.

7 "Divine immanence is more obvious in the teachings of the Stoics who transcend even the dualism of both Plato and Aristotle. For them, as for all Greek thinkers, the universe is a living being

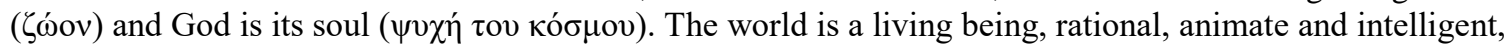
not only because the divine indwells in the world, but also because God and the world are one in substance." Eusebius A. Stephanou, "Divine Indwelling in the World," Greek Orthodox Theological Review 4, no. 2 (1959): 139.

${ }^{8}$ For Plato the cosmos is a world-soul as well, but the world was created by a Demiurge which was created by God, as Cooper demonstrates from the Timeaus. "The particular Form used by the Demiurge to make the cosmos as a whole is Living Being,... Thus this world came to be, by the gods' providence, in very truth a living creature with soul and reason.' The cosmos is a living being, 'a single visible living creature, containing within itself all living things,' 'a body whole and complete, with complete bodies for its parts." Cooper goes further to differentiate between God and the world soul, showing that Plato is most likely not a panentheist; "Timaeus does locate the world in the World-Soul. So, if the World-Soul is part of God, Plato is a panentheist. There are hints in this direction. Timaeus (34ab) refers to the World-Soul as 'a god.' Furthermore, in Philebus (30c) Plato asserts that the divine Mind who wisely orders the universe has a Soul: 'There could be no reason and wisdom without a soul.' If the Soul of
} 
pantheists because of the union of the divine with the world-soul, rather than

panentheists. ${ }^{9}$ For some panentheists, the divine soul includes the body of the world

within it but transcends that body. There is a great deal of diversity in the understanding

of what panentheism actually is and the embodiment of God in the world is only one of

the elements included in the debate over defining panentheism. ${ }^{10}$

eternal divine Reason can be identified with the World-Soul of Timaeus then the World-Soul is an aspect of God, and Plato is a panentheist. But caution is warranted. An essential difference remains between 'the god who is divine Reason and other beings Plato calls gods.' As already mentioned, Timaeus $34 \mathrm{ab}$ refers to the World-Soul as a god, 'the god who was sometime to be. But this god was planned and generated by the Demiurge, who is 'the god who is forever.' The World-Soul is more likely a quasi-divine creation of the Demiurge because Timaeus also explains the creation of the traditional Greek gods' and even alludes to the physical universe as 'a perceptible god.' Plato readily calls created things 'gods.' And he retains an absolute distinction between the god who is eternal and uncreated and the other 'gods' who are generated and participate in time. The World-Soul is clearly in the latter category. The worlds being 'in the WorldSoul' do not place the world in the eternal God who made the world. Thus Plato is not a straightforward panentheist." Cooper, Panentheism, 35-36, 38.

9 "The Stoics identify divine Reason with the Soul of the world, but they turn out to be naturalistic pantheists rather than panentheists. We consider them in order to highlight the difference between pantheism and panentheism and as forerunners of thinkers such as Spinoza. Stoicism flourished periodically from Zeno (d. 264/263 B.C.E.) to the Roman emperor Marcus Aurelius (d. 180 C.E.). It teaches that the physical universe is ordered and animated by an immanent Logos or divine Reason. The diversity of nature exists within a single unity. According to Aurelius, all things are mutually intertwined, and the tie is sacred.... For there is both one Universe made up of all things and one God immanent in all things, and one Substance, and one Law, one Reason common to all intelligent creatures, and one Truth. A 'seed' of the divine Reason [logos spermatikos or semen rationalis] is in every individual being. It manifests itself as the life force in plants, desire in animals, and reason in humans. By using these capacities, creatures participate in God. Humans exercise all three-life, desire, and reason - and thus participate in God most fully. 'You are a fragment of God; you within you a part of Him.... Whenever you mix in society, whenever you take physical exercise, whenever you converse, do you not know that you are nourishing God, exercising God? You are bearing God about with you.' The emphasis on participation in God is very strong. Could this be panentheism? After all, God and the universe are distinguishable, and the universe exists in God as a body in its soul. The famous lines Paul quoted on Mars Hill (Acts 17:28) are by a Stoic poet, Epimenicles the Cretan: 'in him we live and move and have our being.' Perhaps the Stoics are the original proto-Christian panentheists. This conclusion is, however, unwarranted. Stoicism rejects the dualism between the Ideal and the material realms that ensures the metaphysical God-world distinction for Plato. The primary reality for the Stoics is the living, rational universe itself. 'The substance of God, Zeno says, is the entire cosmos and the heaven.' Again, Aurelius 'one Universe' and 'one God' are not ontologically distinct beings but different aspects or dimensions of the 'one Substance.' Thus Stoicism is not panentheism but naturalistic pantheism. It anticipates Bruno Spinoza, John Toland's Pantheism in (1720), and Einstein, not Schleiermacher, Schelling, and Hegel." Cooper, Panentheism, 38-39.

${ }^{10}$ Brierley talks about eight different common themes of discussion over the definition of panentheism: "the cosmos as God's body; language of 'in and through'; the cosmos as sacrament; language of 'inextricable intertwining'; the dependence of God on the cosmos; the intrinsic, positive value of the cosmos; possibility; and degree Christology. These features can be applied as a test to theologians to see whether or not they can be described as panentheist." Michael W. Brierley, "Naming a Quiet Revolution: The Panentheistic Turn in Modern Theology," in In Whom We Live and Move and Have Our Being: 
Recognized by some theologians as the father of panentheism, Plotinus seems to combine the separate divine creator with the world of the stoics while keeping the divine beyond the world through the process of emanation. The divine one is the source from which all other things emanate through the progression of thought from the soul to the body. Everything, which exists, emanates from the one, is in the one, and is to return to the one. ${ }^{11}$

Turning attention from Greek philosophers to the early church fathers, there is some argument between historians about whether there is a split between the teachings of the Western and Eastern fathers regarding the ontological nature of divine-human indwelling ${ }^{12}$ Both the Eastern and Western fathers still claim that there is an ontological

Panentheistic Reflections on God' Presence in a Scientific World, ed. Philip Clayton and Arthur Peacocke, Ed.(Grand Rapids, MI: William B. Eerdmans Publishing Co., 2004), 6. This dissertation makes significant use of the work of Cooper to talk about panentheism. The purpose for this is demonstrating the historical thread of an immanent view of God. The different understandings of panentheism however call for a brief section of definition of panentheism, which can be found in the "theological framework" section later in this chapter.

11 "But Plotinus's panentheism goes even deeper. The World-Soul and all that it contains are part of a higher unity grounded in the One. On the one hand, Plotinus makes clear ontological distinctions between finite physical beings, the universe as a whole the World-Soul, the Intellect, and the ultimate One. On the other hand, all things emanate from the One, return to it, and are contained within it. Thus all things are within the divine One, which infinitely transcends all things. Reale succinctly summarizes Plotinus's inclusive hierarchy: 'In a certain sense the world itself is in God, since the world is in the Soul, the Soul is in Mind (Nous), Mind is in the One, and the One is not in something else but encloses everything entirely within itself.' All things are not divine, but all participate in God, who infinitely transcends all. This is classical panenthelsm." Cooper, Panentheism, 43.

${ }^{12}$ Stephanou clearly draws the distinction between the Eastern tradition in Greek Theology and the Western Latin Tradition. "While the Christian Greek tradition of the early Church held to the belief in an immanent God, Latin theology eventually put the stress on the transcendence of God. Reformation theology subsequently gave added emphasis to divine transcendence and marked a further step in the West's departure from the spirit of the ancient Church.... Whereas 'the fundamental principle of Greek theology, underlying every position which it assumed, was the doctrine of the divine immanence- the presence of God in nature, in humanity, in the process of human history, in Latin thought it may be everywhere discerned as the working of another principle, sometimes known as Deism, according to which God is conceived as apart from the world, localized at a vast distance in the infinitude of space."

Stephanou, "Divine Indwelling," 135-136. Gleason, on the other hand, sees a possibility of Eastern and Western systems of thought complementing each other, rather than conflicting. "There are certain texts of St. Paul which could be reasonably construed to suggest formal causality. These are the texts in which the Holy Spirit is spoken of as sealing and anointing the grace-informed soul. The comments of the Greek Fathers on these texts are what have given rise to the question of the possibility of seeking in formal 
indwelling. ${ }^{13}$ The Western Fathers focus more on the substantial/essential union of God with the righteous soul while the Eastern fathers promote the immanent presence of God in the world, within all of life, sustaining and containing all created things. ${ }^{14}$

Following the transcendent school of thought, some of the Western church fathers supported a possession of the Spirit and the shaping of the soul. The possession of the spirit is a gift only for the just and is administered at baptism. It is this possession of the spirit that enables the just believer to live a righteous life. ${ }^{15}$ Cyril of Alexandria describes

causality an explanation of the mode of the divine indwelling. There has been a tendency in modern theology to contrast the so-called oriental theology on this matter with Latin theology. These two views are seen as complementary rather than contradictory." Robert W. Gleason, The indwelling Spirit (Staten Island, NY: Alba House, 1966), 24. Fancis L. G. Cunningham repeatedly develops the case that the Western father's accepted and built upon the Eastern fathers. The Eastern fathers were the first to speak on indwelling, and the silence of the Western fathers until the $4^{\text {th }}$ Century suggests no disagreement on the subject (36). Subsequently the Western fathers, such as Hilary, Jerome, and Ambrose used ideas from, and quoted Origen, Didymus, and the Cappadocian Fathers. Francis L. B. Cunningham, The Indwelling of the Trinity; A Historico-Doctrinal Study of the Theory of St. Thomas Aquinas (Dubuque: Priory Press, 1955), $36,40,47-48$.

${ }^{13}$ According to Cunningham there are four significant points, which can be drawn from both Scripture and the Eastern fathers that some Western fathers agree with. "From this teaching the following points can be abstracted: 1) The three divine Persons really, personally and substantially dwell in humanity. 2) This special presence of the Trinity is entirely distinct from the common presence of God in all things. 3) It is realized only in the just, and therefore in some way by means of grace. 4) It is not exclusive to the Holy Ghost, but because of His personal property it is appropriated to Him." Cunningham, The Indwelling of the Trinity, 36 .

${ }^{14}$ In his interpretation of the church fathers, Gleason demonstrates the strength of the union with the spirit and soul in the thought of Irenaeus. "St. Irenaeus did not depart from this traditional doctrine of the sealing and the anointing. His expressions of our union with the Holy Spirit are in fact quite as strong as those used of the Hypostatic Union. The Holy Spirit is the object of a participation and a communion. The Spirit is united to the body and soul of man. St. Irenaeus spoke of a mixture and union of the Spirit and man, of an insertion of the Spirit into man, of an inpouring of the Spirit." Gleason, Indwelling Spirit, 35. In his analysis of Galtier, Gleason demonstrates the eastern fathers' pervasive sense of the Holy Spirit applied to all of creation in a state of grace. "P. Galtier states that the Fathers conceive the special presence of the inhabitation, not as a presence that results from our acts, but as an ontological presence that comes with the state of grace. 'They describe this presence under the image of an application, to the substance of the just soul, of the very substance of the divine Persons and by no means as an intellectual apprehension by man of their action upon him." Gleason, Indwelling Spirit, 33-34.

15 "The Fathers of the Church also have set forth this privilege of possession that God grants to the just soul. St. Cyril of Alexandria says that without this possession of the Holy Spirit there is no question of our being truly children of God. Novatian describes the Spirit as given to us as the architect of our spiritual life. We have received him in baptism and he regenerates us in that sacrament, says Aphraates. Athanasius says that He is granted to all who confess Christ. It is because we possess the Spirit that we also possess the entire Trinity, Chrysostom tells us. St. Cyril of Alexandria goes on to say that we merit to be called gods 
the union of God with the soul as the process of deification, by which he means to sculpt and form the soul into the image and likeness of the divine substance and nature. ${ }^{16}$ Continuing along the lines of a formal cause, Cyril states that the Holy Spirit works like a seal in wax, as the Spirit is pressed into the wax, thus the soul takes on the form of the divine nature. ${ }^{17}$ Whether the Holy Spirit is the efficient cause of the life of the soul, empowering the believer to think live and act in certain ways, or the formal cause, like a seal around which the soul is being shaped, the church fathers present a union of the Spirit of God with the soul of the believer. ${ }^{18}$

for we possess God dwelling within us permanently. And because we have received the Spirit, we share in the life of God. St. Gregory expresses the intimate union that results from grace with beauty: He then tells us that God is united to gods and is intimately known by them. In the Homily of the Gospel of Pentecost, St. Augustine reminds his Christians that although the world cannot know the Holy Spirit, the just man can, for he dwells within the just." Gleason, Indwelling Spirit, 16-17. Cf.: Athanasius, "Four Discources Against the Arians," in Nicene and Post-Nicene Fathers, ed. Philip Schaff and Henry Wace (Buffalo, NY: Christian Literature Publishing Co., 1892), 3, 24; Novation, "Treatise Concerning the Trinity," in Ante-Nicene Fathers, ed. James Donaldson Alexander Roberts, and A. Cleveland Coxe(Buffalo, NY: Christian Literature Publishing Co., 1886), 29; Aphraates, "Demonstrations," in Nicene and Post-Nicene Fathers, ed. Philip Schaff and Henry Wace(Buffalo, NY: Christian Literature Publishing Co., 1890), 6, 14.

${ }^{16}$ While Cyril of Alexandria is an Eastern Father, his work to bridge the East with the West is reflected in his statements concerning the understanding of indwelling. "St. Cyril of Alexandria says: "The Holy Spirit works directly in us uniting us to himself, joining our souls to his Being, so that we become sharers in the divine nature." "The activity of the Holy Spirit is to transform the soul somehow into himself, divinizing it. He sculpts there the divine features, imprints the divine likeness. 'Transforming the souls of men as it were into himself, he sculpts there the image and likeness of the Supreme Substance."' Gleason, Indwelling Spirit, 26. Gleason takes these quotes from Cyril's Dialogue on the Trinity.

17 "'For the Holy Spirit does not paint as an ordinary painter, producing in us the image of something other than himself and so conferring upon us a likeness to God. Rather, since he is God, he impresses himself invisibly in the hearts of the just, as a seal in wax, and he restores to men the divine image and produces a likeness to himself, through the communication of himself." Gleason, Indwelling Spirit, 30. This quote is derived from Cyril's Thesaurus Assertion 34.

18 The church fathers clearly differentiate between the efficient/formal causal indwelling of the human soul by God and the hypostatic union, which is represented in Christ alone. Barthelemy Froget, while building towards Thomas Aquinas' explicit three ways of understanding the union of the believer and the Holy Spirit, also demonstrates this in the church fathers. Barthelemy Froget, The Indwelling of the Holy Spirit in the Souls of the Just: According to the Teaching of St. Thomas Aquinas, trans., M.A. Rev. Sydney A. Raemers, Translated from the 3rd French ed., Forgotten Books (Westminster, MD: The Newman Press, 1952), 48-49, 54, 63-64. The historical significance of the Christological debates in the fourth and fifth centuries clarified Jesus as unique in this regard. 
In contrast to the transcendent-soul union, some of the church fathers emphasized the immanence of the union of the Spirit of God with the world over the transcendence of God's presence beyond the world. This emphasis does not necessarily exclude a unique union with the believer. Both Athenagoras and Justin Martyr taught that the Spirit or the Logos pervades the world. Gregory of Nyssa spoke of the Divine being in all things and all things in him. ${ }^{19}$ Athanasius spoke of the Logos in the world as a body descending into all places and Basil used the Spirit to describe the phenomena that all things are filled by the Spirit. ${ }^{20}$ For the immanent side of the discussion, Maximus the Confessor and Photius might summarize the fathers for future generations: "the spirit is in all sustaining and preserving all."21

According to Outler and Lee, the Eastern Church Fathers were the strongest influences for Wesley's understanding of the divine indwelling of humans, particularly Macarius the Egyptian. ${ }^{22}$ The nature of the union with the Godhead, through the

19 "Athenagoras witnessed to the mind of the Church, saying that 'all things are sustained by His

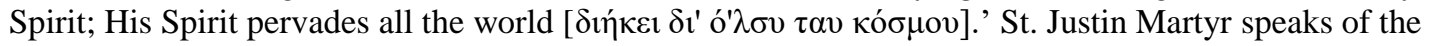
immanence of the Eternal Logos of God. 'The Logos was and is, being in everything [ó \&v $\pi \alpha v \tau i$ ' $\omega v$ ]."” Stephanou, "Divine Indwelling," 142. Justin Martyr, "The Second Apology" https://www.ccel.org/ccel/schaff/anf01.viii.iii.x.html (accessed Oct. 27. 2016), 10; Athenegoras, "A Plea for the Christians" https://www.ccel.org/ccel/schaff/anf02.v.ii.vi.html (accessed Oct. 27, 2016), 6.

20 "Like the other Greek Fathers, St. Athanasius argues for the reasonableness of the incarnation on the grounds of the immanent presence of God in the world. In the light of the reality of God's cosmic indwelling, the incarnation becomes more of a rational, and less of a paradoxical, event. 'If the Logos of God is in the world being a body, He has descended into all places and into all things in particular'...While St. Athanasius dwells on immanence, in terms of the Logos, as a true Alexandrian would, St. Basil speaks

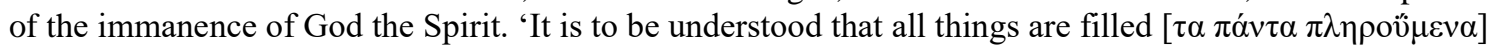
by the Spirit." Stephanou, "Divine Indwelling," 142-143. Athanasius, "The Incarnation of the Word" https://www.ccel.org/ccel/schaff/npnf204.vii.ii.xli.html (accessed Oct. 27 2016), 41.

21 "St. Maximus the Confessor, continuing the tradition as set forth by his predecessors, teaches us that the Spirit resides in the world and in all beings within the world, particularly in man whose rational structure is accounted for by the Spirit's indwelling in him." Stephanou, "Divine Indwelling," 143-144.

${ }^{22}$ Albert Cook Outler has suggested the following line of Werner Jaeger's conclusion that Gregory of Nyssa was the primary source for Wesley's spirituality. Lee, "New Creation", 158. Outler clearly declares Macarius, Gregory of Nyssa, and Ephrem Syrus as the source for Wesley's understanding of the 
indwelling of the Holy Spirit, was for Macarius a substantial abiding through which the soul is able to be face-to-face with God. ${ }^{23}$ The Spirit becomes mystically united to the soul by grace. ${ }^{24}$ The eschatological effect of this union is the glory of the Holy Spirit

Holy Spirit and spirituality. "His central theme (the divine indwelling of human participation) was learned in large part from Macarius, Gregory of Nyssa, and Ephrem Syrus. His concept of Christian koinonia was more Greek than Latin, and this explains his freedom to correct what he regarded as the excessive sacerdotalism within the Anglican ecclesiology that he had inherited. At the center of all these ideas was his understanding of the person and work of the Holy Spirit as God's personal presence in the believer's heart and will and in the Spirit-filled community and its sacraments. This enabled him to think of the Christian believer as indwelt and led by the Spirit within rather than being possessed by the Spirit as if by some irresistible force." This is taken from Outler's Introduction to John Wesley, The Works of John Wesley, ed. Frank Baker and Albert Cook Outler, Bicentennial ed., vol. 1 (Nashville: Arbingdon Press, 1984), 74-76. Hoo-Jun Lee, however, disagrees with Outler: Lee, in describing the work of Reinhar Staat, shows that Macarius the Egyptian is the more likely source for both Gregory of Nyssa and Wesley. "While Jaeger's interpretation is that Macarius was using the material of Gregory to develop his homilies, Staat points out and Lee agrees that Gregory was actually the one making use of Macarius. One of the points made for this argument is that Macarius was a Scripture theologian, which requires him to be solely based on Scripture and therefore would not allow him to use another's work. A second point in the argument shows likely grammatical errors in Gregory's use of Macarius. Finally, Robert S. Brightman, who is a supporter of Gregory of Nyssa, recognizes against his hope, that Wesley does not rejoice in Gregory the way he should if Gregory had been Wesley's primary source (rather than Macarius). "In the light of Wesley's great admiration for the Spiritual Homilies of Macarius, and the affinity of Wesley's thought with Macarius, it becomes clear that the conclusion...that Wesley did not have any extensive knowledge of Gregory of Nyssa is reinforced. For the present study has shown that there is a significant affinity between Wesley and Gregory, and if Wesley responded to Macarius as he did, it seems to be inevitable that he would have responded with at least as much enthusiasm to Gregory. ... .If Wesley sang while reading Macarius, after reading Gregory, he would have shouted!" Lee, "New Creation", 174-176, 177.

${ }^{23}$ Lee demonstrates from Macarius' own writing his understanding of a mystical union of the believer's soul with the bridegroom: “"And being wounded by the heavenly Spirit, continually excited an inflamed desire after the heavenly bridegroom, and longing to be completely admitted to the mystical and inexpressible communion with him in the sanctification of the Spirit; having the face of the soul unveiled and looking with a steady eye upon the heavenly bridegroom, face-to-face in the light which is spiritual, and not to be expressed; it mixes with him in all the fullness of assurance; ... And this is the soul filled with the heavenly life, and becomes the pure habitation of the Spirit." Lee, "New Creation", 192-193.

${ }^{24}$ Grace as the substantive means by which the Holy Spirit indwells the soul, is one still used in the current discussions today. Robert W. Gleason, for example, agrees with De la Taille that the soul is substantially united with the created accident of Grace so that the uncreated act, who is God, can then indwell the soul. Grace as the created act is the substantial union, but it cannot be done without the presence of the Uncreated Act; therefore God is truly present in the soul of the believer through Grace. "Grace is an accidental form which is newly actuated in the soul by the divine indwelling. It is a created actualization of an obediential potency of the soul. But its entire nature as a created accidental form consists in its being a modification of the soul by which the soul actually receives in a created, accidental way the substance of God thus present and communicating himself. God's presence therefore can be understood in terms of a quasi-formal causality. God, the Uncreated Act, by his presence, actuates the obediential potency of the soul to receive him. The actuation of this potency and grace are identical. Grace is the created actuation according to which the actuating Uncreated Act is received in created form. Between God, the Uncreated Act, and grace, his created reception, there is no intermediary. Grace is a 
within the soul, and it will eventually shine from the soul through the body, transforming it into a Spiritual body. ${ }^{25}$

Augustine of Hippo has great influence over many doctrines in the church and divine presence is not to be excluded from that list. Augustine continues the thoughts of other church fathers before him suggesting that divine presence is in all creation as sustainer but the inhabitation of the divine is restricted to the soul of the just. Those who are able to know and thus possess God are those who are truly inhabited by the divine. The inhabitation is also not restricted to the Holy Spirit, the entire Trinity is said to be the inhabitant of those who are in the state of grace. ${ }^{26}$ While Augustine does not explain the "how" of the indwelling, nor explicitly state that the image of God is directly related to the indwelling, his assertions concerning indwelling are influential in the exploration of the writings of the scholastics and Thomas Aquinas. ${ }^{27}$

The majority of the debate concerning divine indwelling in the Roman Catholic

formal modification of the soul." Gleason, Indwelling Spirit, 82.

25 "The goal of perfection presupposes the foretaste of the world to come in the present spiritual life. Glory of the coming age is not separable from the present experience of the Spirit since the Spirit can be properly called the Consummator of the whole divine dispensation. . .'there shooteth out from within the glory of the Holy Spirit, covering the bodies of the saints, which glory they had before, within hidden in their souls. For whatever (the soul) hath at present, the same cometh forth at that time outwardly in the body.' Thus for Macarius' spiritual vision the interior glory will burst forth exteriorly in the resurrection body." Lee, "New Creation", 201.

26 "The two principal sources of St. Augustine's doctrine for the Scholastics are his De Trinitate and his 187th letter, ad Dardanum, De Praesentia Dei, the work from which their doctrine on the presence of God is drawn. From this last a passage admirably sums up Augustine's restatement of the common notions on the inhabitation: It is much more marvelous that, while God is everywhere entire, He nevertheless does not dwell in all things. But who dares to think - unless someone is completely ignorant of the inseparability of the Trinity - that the Father or Son can dwell in someone in whom the Holy Ghost does not dwell, or the Holy Ghost in someone in whom the Father and Son [do not dwell]? Hence it must be acknowledged that God is everywhere by the presence of divinity, but He is not everywhere by the grace of inhabitation." Cunningham, The Indwelling of the Trinity, 48-52.

${ }^{27}$ Cunningham, The Indwelling of the Trinity, 54-55. 
tradition currently seems to be centered on the apparent discrepancies between Thomas Aquinas' commentary on the Sentences and his later Summa Theologica. ${ }^{28}$ The historical development leading to this debate includes the writings of the scholastics. There are several principles of indwelling, which the scholastics and Aquinas alike were trying to explain and held in common. ${ }^{29}$ One of the most relevant of these principles for the ontology of indwelling was that: "The indwelling of God in the soul is a real presence, i.e., physical and substantial, not merely moral." The debate between the scholastics is based on the different interpretations of how the substantial indwelling is to be explained. Is an efficient cause enough to explain the union or must it be a more formal explanation? Some of the scholastics claim that if a believer has the signs of effective change in their lives (efficient cause) this is enough to prove that the divine must be present in the just soul, because these effects are impossible without a true substantial presence possessed and enjoyed by the soul. ${ }^{30}$ Peter Lombard suggests that Holy Spirit should be identified with charity, thus the indwelling is through love, which actually is the Holy Spirit. ${ }^{31}$ Other scholastics argue that the effects/love (the efficient cause) are not enough to require

\footnotetext{
${ }^{28}$ Cunningham, The Indwelling of the Trinity, 11.

${ }^{29}$ Cunningham outlines 7 different common teachings of the schoolmen and many of them are at least hinted at by Augustine. "1) The indwelling of God in the soul is a real presence, i.e., physical and substantial, not 'merely moral...2)This presence is a new presence, completely different from God's common presence in all things...3) This divine inhabitation is realized only by grace...4) This divine inhabitation, realized by grace, is common to the three Persons, father and Son and Holy Ghost...5) This inhabitation of the triune God, realized by grace, is, for the Son and Holy Spirit, the result of Their invisible missions...6) The notion of manifestation...7) The notion of image." Cunningham, The Indwelling of the Trinity, 80-87.

${ }^{30}$ Characterized as the Franciscan interpretation by Cunningham and is exemplified in the Summa Alexandri. Cunningham, The Indwelling of the Trinity, 108, 128.

${ }^{31}$ Cunningham rejects this solution to the explanation of indwelling, calling it a moral union only. Cunningham, The Indwelling of the Trinity, 106-107.
} 
a substantial indwelling, but simply suggest a moral union between the just soul and the divine. ${ }^{32}$ In order for the just soul to truly have a substantial presence within the soul, there must be a true formal union between the divine and the soul, where the soul is literally being shaped in the likeness of the form of the Holy Spirit. ${ }^{33}$

A second principle which is held in common among the scholastics was: "this presence is a new presence, completely different from God's common presence in all things." "While the schoolmen cannot seem to agree on the "how" of the indwelling, it is clear that the schoolmen accept the transcendent position requiring the divine indwelling to be a union reserved for the righteous soul and distinct from the common immanent presence of the divine in general creation. The answer to the lack of an adequate explanation, it is argued, is to leave the solution up to Thomas Aquinas. ${ }^{35}$

Aquinas describes three different levels of divine presence within creation. First is

32 This is Cunningham's position and he demonstrates it as Thomas Aquinas' position as well, in response to the Summa Alexandri. "The inadequacies of this theory - proposing the faculty of enjoying the Trinity as a formal reason for the real presence of the divine Persons - are immediately apparent. Against such an explanation, the criticism John of St. Thomas will later level against the proposals of Suarez, is equally valid. As St. Thomas himself points out, 'real, physical union is an efficient effect of love, but love itself can never be the formal reason for this real presence, nor even a disposition by means of which the loved one becomes present.' No matter how perfect love may be, neither on the natural nor on the supernatural plane can it do more than seek and tend toward real and physical union. It must remain in the moral and intentional order, as opposed to the order of substantial presence." Cunningham, The Indwelling of the Trinity, 128-129.

${ }^{33}$ Even within the formal solutions to the problem of how indwelling works, there are disagreements. For example, Albert proposes an exemplar solution in which the divine is the external exemplar producing formal effects upon the just soul. But an exemplar must be external by nature, according to Cunningham, and therefore cannot be a true indwelling. Cunningham, The Indwelling of the Trinity, 148-150.

${ }^{34}$ Cunningham, The Indwelling of the Trinity, 80-87.

${ }^{35}$ Cunningham presents the case that because these two options cannot agree and are inadequate to truly find a real physical/substantial union in regards to the divine indwelling of the just soul, suggests that the solution is left for Thomas Aquinas to discover and adequately explain. Cunningham, The Indwelling of the Trinity, 164. 
the general presence of providence within all of creation. ${ }^{36}$ The second is the union of indwelling through the knowledge and love of the just soul of the divine. The third level of divine presence was reserved only for the incarnation and that is the hypostatic union of the divine nature with human nature in the person of Jesus Christ. ${ }^{37}$ Aquinas affirms that the indwelling union of the divine in humanity is a real substantial union with the soul, as a part of the transcendental model of indwelling.

The reformers don't seem to make much change in the understanding of the ontological nature of the divine-human indwelling. The method of receiving the indwelling is directed more towards the receiving the word of God through faith. ${ }^{38}$ But it

${ }^{36}$ This general presence is neither a substantial one nor an accidental one but seems to be described as an efficient cause, the agent who causes existence, by which God has given life and continues to sustain life in the creation in general. Niels Henrik Gregersen, "Three Varieties of Panentheism," in In Whom We Live and Move and Have Our Being: Panentheistic Reflections on God' Presence in a Scientific World, ed. Philip Clayton and Arthur Peacocke(Grand Rapids, MI: William B. Eerdmans Publishing Co., 2004), 23.

${ }^{37}$ Froget, Indwelling - Thomas Aquinas, 48-49, 54, 63-64. Thomas Aquinas, "Sentences" http://www.corpusthomisticum.org/snp1035.html\#2760 (accessed Sept 14 2017), Lib. 1., d. 37 q. 1. , a. 2 ; Thomas Aquinas, "Summa Theologica" http://www.corpusthomisticum.org/sth4002.html\#46864 (accessed Sept 14 2017), III., q. 2., a. 10.

38 The sacraments are still given significant weight as the means by which the believer is united with Christ. Jonathan Linman demonstrates how Luther emphasizes both baptism and the Eucharist, although both sacraments require the faith of the believer to actually be effective. "It is much more: through the sacramental act of baptism God binds himself ontologically to a sinner and is one with him through his whole earthly life, if he adheres to Christ in faith. Such union is reliant on divine presence in the sacrament. Or as Luther suggests in a sermon on Matthew 3:13-17, 'We should not doubt at all that wherever one is being baptized the heavens are assuredly open and the entire Trinity is present and through its own presence sanctifies and blesses the person being baptized.' ... If the faith of believers unites them to Christ in such a way that there is an ontological participation in the divine life, this process must be understood in the context of mediation through the proclamation of the Word ('for faith comes through the Spirit in the hearing of the Word') and the administration of the sacraments of baptism and the Eucharist (which awaken and strengthen faith). In short, it is by means of sharing in the mission and ministry of the whole Church that the believer is deified." Jonathan Linman, "Martin Luther: 'Little Christs for the World'; Faith and Sacraments as Means to Theosis," in Partakers of the divine nature: the history and development of deification in the Christian traditions(Grand Rapids, MI: Baker Academic, 2008), 193-194, 196. J. Todd Billings explains that John Calvin looks to the Spirit as the means by which the believer is indwelt by the divine and is empowered to be able to enact Christian love as well as the agent which gives the Eucharist the power to vivify the life of the believer. "For Calvin, the fundamental unity of divinity and humanity is not only apparent in the Spirit's prevenient work, but in God's 'gift' of faith to believers. Although the reception of faith involves the voluntary assent of believers, and the assent 'is properly called ours,' it does not 'derive from us' in exclusion from God, but is a work of the Spirit. Moreover, when believers act in 
continues to be a substantial union of the just soul with a transcendent God, both for the empowerment and vivification of the current life. ${ }^{39}$ The divine union will be fully realized in the beatific vision. ${ }^{40}$

Wesley continues to support the dualistic nature of humans, being divided into body and soul. He also suggests that the divine indwelling of humans is what it meant for humanity to be created in the image of God. When humanity fell, the Holy Spirit no longer dwelt within the human soul. Redemption is the process of restoring the divine image, thus reclaiming the divine indwelling of humans. ${ }^{41}$

love, it is not 'as if constrained by a necessity of the law;' but voluntarily. So, how can Calvin speak positively of the human acts of 'assent' and 'voluntary' actions of love? For Calvin, the free action of a human being is not in competition with the action of the Spirit. The Spirit empowers these actions - and deserves the praise for these actions - but these actions are still 'properly called ours.' As a part of this account, Calvin denies the popular medieval doctrine of 'infused habits,' along with the distinction between 'natural' and 'supernatural' virtues. Instead, Christian acts of love emerge directly from the indwelling activity of the Holy Spirit. Yet, in Calvin's account, the human faculties are not bypassed in this process, but activated by the Spirit. Moreover, the divine will is not coercive toward the human person. Rather, God 'renews a right spirit in their inner nature' so that the will voluntarily obeys God, consenting to faith through the work of the Spirit." J. Todd Billings, "John Calvin: United to God through Christ," in Partakers of the divine nature: the history and development of deification in the Christian traditions(Grand Rapids, MI: Baker Academic, 2008), 203-204, 210. For further reference on Calvin's views on the divine-human relationship and the importance of the word, baptism, and the Eucharist see: Philip Walker Butin, "Calvin, the Trinity, and the Divine-Human Relationship" (Dissertation, Duke University, 1991).

${ }^{39}$ Billings shows that Calvin clearly taught a substantial union with Christ so much so that believers are said to become one substance with Christ without disappearing into the divine nature through full absorption. Billings, "John Calvin," 210-211.

${ }^{40}$ In Calvin's debate with Osiander, Billings points out, that Calvin is careful to state that the divine indwelling is not through the infusion of the divine essence but is instead through the Spirit and is careful to draw a clear distinction between the creator and his creation. Billings also shows how Calvin follows church fathers like Ireneaus and Augustine to emphasize the future union of the believer with God in the beatific vision. While being careful not to make the believers consubstantial with the divine, they are invited into participation in the being of God. Billings, "John Calvin," 207, 205.

${ }^{41}$ John Wesley, "The Sermons of John Wesley-Sermon 141: On the Holy Spirit", Wesley Center for Applied Theology http://wesley.nnu.edu/john-wesley/the-sermons-of-john-wesley-1872edition/sermon-8-on-the-holy-spirit/ (accessed November 20 2013), I. Through this focus on the restoration of the image of God we can see the influence of previous church fathers and theologians, such as Augustine, Aquinas, and Calvin, as mentioned previously in this historical background. 


\section{From John Wesley to John Cobb}

The second section of this historical background will present the development of thought concerning the divine indwelling of humans from the theology of Wesley to the theology of Cobb. The first stage of this development is the rise of Modern Theology, with Wesley standing at the very beginning of modernity's timeline. ${ }^{42}$ The emphasis of the Modern era on empirical evidence was apparent in Wesley through his interest in the natural world and intellectual critique and agreement with proponents of different viewpoints. ${ }^{43}$ Wesley is on the transcendent, classical theistic side of Modern Theology, ${ }^{44}$ and if one is to arrive at Cobb's panentheistic understanding of the divine indwelling of humans, a second stage of development is required. One must then follow the progress of modern theology to process theology.

Wesley interpreted the ontological nature of divine-human indwelling following classical theism. He wrote about God as distinct from his creation and yet omnipresent throughout all of the universal cosmos. ${ }^{45}$ Humanity was created in the image of God,

\footnotetext{
${ }^{42}$ Wesley is at the beginning of the era of Modern Theology and is consistently included in the modern theological section of Gregg Allison's Historical Theology. Gregg R. Allison and Wayne A. Grudem, Historical theology : an introduction to Christian doctrine : a companion to Wayne Grudem's Systematic theology (Grand Rapids, Mich.: Zondervan, 2011).

${ }^{43}$ Wesley, Works, 72-73.

${ }^{44}$ Wesley's thought will be more fully developed in Chapter 2 of this dissertation. It is enough to say at this point that Wesley affirmed a general providential immanent presence similar to that of Aquinas but reserves the substantial indwelling presence for that of the righteous soul. Cf. the next footnote in this chapter. Outler's introduction is helpful in demonstrating the value that Wesley put on the classical-modern interpretation for his theology: "In Wesley's own case this classical orientation was very much more that ostentation; it was an integral element in his theological perspective. He knew how deeply classical culture had shaped patristic Christianity. He also knew how decisively even in his own time, its rediscovery was reshaping the emergent Enlightenment in Europe.” Wesley, Works, 72-73.

45 "The general character, therefore, of man's present state is death, -- a death from God, whereby we no longer enjoy any intercourse with him, or happiness in him; we no longer shine with his glory, or act with his powers. It is true, while we have a being, 'in him we must live, and move, and have our being;' but this we do now, not in a filial way, but only in a servile one, as all, even the meanest creatures, exist in him. It is one thing to receive from God an ability to walk and speak, eat and digest, -- to be supported by his
} 
which Wesley directly states is the indwelling Spirit. ${ }^{46}$ When humanity fell into sin

however the Spirit withdrew from the soul as the soul separates from the body at death

and may be eternally separated from God. ${ }^{47}$ Salvation, for Wesley, is the process of

restoring the image of God beginning with God's providential preventing grace followed

by justifying and sanctifying grace. At the moment that the believer accepts the atoning

sacrifice of Jesus Christ the believer is both justified and receives the Holy Spirit. ${ }^{48}$

Wesley is clear that to be a Christian is to have the Holy Spirit. ${ }^{49}$ Without the Holy Spirit

hand as a part of this earthly creation, and upon the same terms with it, for farther trial or vengeance; and another, to receive from him a life which is his own likeness, -- to have within us something which is not of this creation, and which is nourished by his own immediate word and power." John Wesley, On the Holy Spirit, Third ed., The Works of John Wesley, vol. 7 (London: Wesleyan Methodist Bookroom, 1872), 511. See also Wesley, Omnipresence, 242-243. Kenneth J. Collins corroborates that Wesley holds together the immanence and transcendence of God. "Wesley aptly holds together both the immanence and the transcendence of God, never one affirmation without the other. That is, to stress immanence to the neglect of transcendence would result in pantheism; to stress transcendence to the neglect of immanence would result in separation in which God would be and would remain unknown." Kenneth J. Collins, The Theology of John Wesley: Holy Love and the Shape of Grace (Nashville, TN: Abingdon Press, 2007), 23-24.

46 "Our first parents did enjoy the presence of the Holy Spirit; for they were created in the image and likeness of God, which was no other than his Spirit." Wesley, Holy Spirit, 509.

47 "In the beginning, the heavenly Word, -- being a Spirit that issued from the Father, and the Word of his power, -- made man an image of immortality, according to the likeness of the Father; but he who had been made in the image of God, afterwards became mortal, when the more powerful Spirit was separated from him." Wesley, Holy Spirit, 512-513. 47 "Man did disobey God. He 'ate of the tree, of which God commanded him, saying, Thou shalt not eat of it.' And in that day he was condemned by the righteous judgment of God. Then also the sentence whereof he was warned before, began to take place upon him. For the moment he tasted that fruit, he died. His soul died, was separated from God; separate from whom the soul has no more life than the body has when separate from the soul." John Wesley, Justification by Faith, Third ed., The Works of John Wesley, vol. 5 (London: Wesleyan Methodist Bookroom, 1872), 54-55. This possibility of separation of the divine presence from the soul shows the markers of classical theism in Wesley. Panentheism does not allow for any part of any created thing to be separated from God ontologically as all is in God. Wesley however clearly stated that God did withdraw from the soul at the fall and will stay withdrawn eternally if the person does not accept Christ and surrender to his will in their lives. Wesley, Righteousness of Faith, 69.

48 "'Believe in the Lord Jesus Christ, whom God hath given to be the propitiation for thy sins, and thou shalt be saved;' first, from the guilt of sin, having redemption through his blood; then from the power, which shall have no more dominion over thee; and then from the root of it, into the whole image of God. And being restored both to the favour and image of God, thou shalt know, love, and serve him to all eternity." Wesley, Sermon CIX, 227-230.

49 '"'Hast thou received the Holy Ghost?' If thou hast not, thou art not yet a Christian. For a Christian is a man that is 'anointed with the Holy Ghost and with power.' Thou art not yet made a partaker of pure religion and undefiled. Dost thou know what religion is? that it is a participation of the divine 
as a stamp upon the soul (formal cause), the justified believer will not even be aware of the presence of the Spirit nor will he or she be able to display the fruits of the Spirit in a righteous life (efficient cause). ${ }^{50}$ The Holy Spirit awakens the spiritual senses of the believer which have been unavailable until justification. Through the spiritual senses one is able to come to the knowledge and love of God, much like how one comes to knowledge of the physical world through the physical senses. ${ }^{51}$ Without the spiritual senses the person would be unable to be aware of the more real "unseen" reality. ${ }^{52}$ Modern theology represents a turn to empirical evidence. Modern science and theology, however, relegated God to a different sphere of understanding, to be

nature; the life of God in the soul of man; Christ formed in the heart; 'Christ in thee, the hope of glory?' happiness and holiness; heaven begun upon earth? 'a kingdom of God within thee; not meat and drink,' no outward thing; 'but righteousness, and peace, and joy in the Holy Ghost?' an everlasting kingdom brought into thy soul; a 'peace of God, that passeth all understanding;' a 'joy unspeakable, and full of glory?" Wesley, Awake, 30-31.

${ }^{50}$ Wesley does not use the terms formal and efficient cause to describe the presence of the Holy Spirit with in the soul, but he does describe both the formal and efficient causes in effect. The Holy Spirit is the stamp or impression upon to the soul which harkens back to the early church fathers as previously discussed in this chapter. Wesley, Semon on the Mount I, 256-257. For Wesley, the Holy Spirit must also be present in order for there to be any external evidence of salvation including the love and knowledge of God not to mention the ability to live a righteous life. Wesley, Witness of the Spirit, 124, 125-126.

51 "So it is with him that is born of God. Before that great change is wrought, although he subsists by Him, in whom all that have life 'live, and move, and have their being,' yet he is not sensible of God; he does not feel, he has no inward consciousness of His presence. He does not perceive that divine breath of life, without which he cannot subsist a moment: Nor is he sensible of any of the things of God; they make no impression upon his soul.” Wesley, Privilege, 225-226. Wesley, Privilege, 150-151. Wesley, Living without God, 354; Kenneth Loyer, God's Love Through the Spirit: the Holy Spirit in Thomas Aquinas \& John Wesley (Washington, D.C.: The Catholic University of America Press, 2014), 36-37.

${ }^{52}$ Wesley continues to hold to a cosmological reality influenced by platonic ideas. "Accordingly, a believer, in the scriptural sense, lives in eternity, and walks in eternity. His prospect is enlarged: His view is not any longer bounded by present things: No, nor by an earthly hemisphere; though it were, as Milton speaks, 'ten-fold the length of this terrene.' Faith places the unseen, the eternal world continually before his face. Consequently, he looks not at 'the things that are seen;'- 'Wealth, honour, pleasure, or what else This short-enduring world can give;' these are not his aim, the object of his pursuit, his desire or happiness; but at 'the things that are not seen;' at the favour, the image, and the glory of God; as well knowing that 'the things which are seen are temporal,' - a vapour, a shadow, a dream that vanishes away; whereas 'the things that are not seen are eternal;' real, solid, unchangeable.” John Wesley, On Eternity, Third ed., The Works of John Wesley, vol. 6 (London: Wesleyan Methodist Bookroom, 1872), 196. 
distinguished from the physical world. ${ }^{53}$ God, therefore, became more and more distant. The supernatural was removed from the natural world since it was deemed to be impossible for the supernatural to be objectively observed and studied. ${ }^{54}$ The atomistic epistemology of modernity proposed that every object of study could be broken down to its smallest static part and thereby understood. ${ }^{55}$ Then as the relationships between the smallest particles, the atoms, were understood, then the entire natural world could be understood. Some modern theologians took the same approach by believing that once theology was broken down into its most basic parts - God could be fully understood. ${ }^{56}$ This would purportedly lead to a utopia of knowledge for the human race and the natural world. ${ }^{57}$ With the increase of knowledge, the human beings would also progress in their treatment of each other. Thus theologically, the kingdom of God could be established on earth. Human reason and experience had won the day and would be the solution for all

53 "The solution to the problem was simple enough: divide the world into two realities, one a material world over which science had to final say, and the other, a spiritual world over which the Church had final say. This could be done by making a radical distinction between matter and mind." (29) "Thus culture became separated finally into two different spheres: the scientific sphere investigated the world as machine which was no longer seen as the product of God but simply existed in itself, while religion and philosophy (and the whole of humanities) were concerned with an inner world in which it was permissible to deal with the mental and spiritual." (61) Edge Hoyt, A Constructive Postmodern Perspective on Self and Community: From Atomism to Holism (Lewiston: E. Mellen Press, 1994), 29, 61.

${ }^{54}$ David Ray Griffin explains the modernistic removal of the supernatural from the natural world because of the inability for the divine to be observed through the senses, thus modernism proposed a material-mechanistic worldview devoid of God. David Ray Griffin, "Panentheism: A Postmodern Revelation," in In Whom We Live and Move and Have Our Being: Panentheistic Reflections on God' Presence in a Scientific World, ed. Philip Clayton and Arthur Peacocke(Grand Rapids, MI: William B. Eerdmans Publishing Co., 2004), 40-41.

${ }^{55}$ Hoyt, Atomism to Holism.

${ }^{56}$ Lancelot Law Whyte, Essay on Atomism, from Democritus to 1960, [1st ] ed. (Middletown, CT: Wesleyan University Press, 1961), 15-17.

${ }^{57}$ Paul G. Hiebert and ebrary Inc., The Missiological Implications of Epistemological Shifts Affirming Truth in a Modern/Postmodern World (Harrisburg, PA: Trinity Press International, 1999). 
scientific and theological problems. ${ }^{58}$

Two primary options for the divine-human indwelling developed in modernism.

The first is a more transcendent view of God, seen through the perspective of a marked separation of the natural from the supernatural, in either skepticism of the existence of God or an increased dualism. From this perspective, the only connection for God and the human being was through the encounter or experience of God with the soul. ${ }^{59}$ The second option for the divine-human indwelling was to merge God's being/reality with the being/reality of the natural world, while trying to preserve the personhood of God, resulting in the all-inclusive immanence of panentheism. ${ }^{60}$

In order to fully demonstrate the development of theology concerning the divinehuman indwelling from Wesley to Cobb, one must understand process theology. There are at least two identifiable reasons for the birth of process theology and the emergence of the post-modern panentheist doctrine. The first is the emphasis of the idealists of the

${ }^{58}$ Hiebert and ebrary Inc., Missiological Implications, 11-12.

${ }^{59}$ David Hume removed the supernatural by skepticism, Immanuel Kant allowed for the knowledge of the supernatural only in an ethical sense. The morality and ethics, which God has placed in the soul of a human, is the only knowable involvement of God in the world. Kant dualistically separated the pure reason of the natural world and the practical reason of ethics. Taken to its logical conclusions, science and religion are still separated and the only importance of Jesus was as a good moral example by which the religious ethics were modeled. For fuller development on these ideas, see Olson's chapter entitled "Modernity Challenges Traditional Theology." Roger E. Olson, The Journey of Modern Theology: From Reconstruction to Deconstruction (Downers Grove, IL: IVP Academic, 2013).

60 The immanent option for divine-human indwelling was initially based on the more pantheistic philosophy of Hegel. Hegel described God as absolute Spirit, and as such he was a part of the natural order and the natural order was a part of his being. Olson, The journey of modern theology, 93. Cf. Quentin Lauer, Hegel's Concept of God (Albany: State University of New York Press, 1982), 79, 272. There is a variety within the panentheistic solutions for this problem. Gregersen presents three basic varieties including: soteriological, expressivist, and dipolar or Whideheadian panentheism. Gregersen, "Three Varieties." For an even broader sample of the different forms of panentheism in scholarship reference Brierley's work. Brierley, "Naming a Quiet Revolution." Griffin suggests that the dipolar panentheism of process theology is the most effective in allowing for the transcendence and immanence of God at the same time within the context of the natural cosmos. Griffin, "Panentheism," 42-46. 
nineteenth century, which included an "assimilation of evolutionary values." The second came out of the passibilist revolution as it sought to reinterpret the love of God due to the humanistic atrocities of human suffering in the twentieth century, including both World Wars. ${ }^{61}$

Hegel had already suggested the immanent view of panentheism on the basis of absolute being. Process theology, through the philosophy of Whitehead, continued the exploration of essentially uniting God with the world.$^{62}$ Process theology's panentheism applies the scientific model of evolution and process to the being of God, as well as drawing God into the suffering of the world. The premise of indwelling in the panentheistic system is: all of reality is included in God and God is luring each occasion of experience through loving persuasion but never coercion. As the individuals respond to the primordial will of God, they participate in the being of God in mutual immanence and all occasions whether responsive or not become a part of the consequential nature of God. The consequent nature of God could become a type of the utopia, which modernism dreamed of, but it just might not come about. This is because God is limited to the knowledge of past and present, thus excluding a nonexistent future and his power is limited to persuasion; thus, there is no guarantee that his goal will come to pass. ${ }^{63}$

${ }^{61}$ Brierley, "Naming a Quiet Revolution," 13.

${ }^{62}$ Brierley, "Naming a Quiet Revolution," 13. Cooper has written a complete history of Panentheism, from Plato to Whitehead and Cobb. I will not attempt to duplicate his work here. Spinoza, Hegel, and Shelling are just a few along the way in the development of pantheism and panentheism, and Cooper shows the progression of the dipolar understanding of the panentheistic God/world relationship. Because this dissertation focuses on John Cobb, whose major source was Whitehead, I will not spend much time on the previous minds in the development of panentheism. Instead, I will turn my attention to Whitehead. See Cooper, Panentheism. For other brief accounts on the history of panentheism Cf. Brierley, "Naming a Quiet Revolution."; Gregersen, "Three Varieties."; Griffin, "Panentheism."

${ }^{63}$ This is also a solution to the question of theodicy. God is limited in his power; therefore he is not responsible for the evil done by creatures that resist his persuasive will. For a fuller discussion of the historical development of process theology, see Olson's Chapter 6b. Olson, The Journey of Modern 
Cobb regularly admits that Whitehead is his main influential source for his system of theology. Whitehead views all of reality as a series of experiential occasions or occurrences which are prehended and organized by dominant occasions to become a society of occasions. Democratic societies of occasions have no ruling or monarchical occasion to drive them towards any aim, but individuals who have a mind or soul are those who have these dominant occasions at the center of their society. Each occasion prehends the previous actual occasion and will then be a part of the potential future occasion. This means that the fabric of all reality is connected as a part of the society of occasions. ${ }^{64}$

God is dipolar, one pole is a collection of all of these actual occasions in his consequential nature and within the other pole God has all potential occurrences in mind for each society of occasions in his primordial nature. ${ }^{65}$ God, through his primordial will, lures through persuasion all other societies of occasions or beings toward what he sees as

Theology.

64 "Whitehead's system explains the entire universe in terms of actual occasions. The things that we humans ordinarily experience are not actual occasions but 'societies of occasions.' Even atoms and molecules are societies. An entity is a group of occasions that occur in an organized structure or 'society' that endures through time, exhibits distinguishing properties, and stands in relation to other entities. Thus a hydrogen atom is a society of a particular structure with distinctive characteristics and capacities. A living cell is a complex of structures and substructures of molecules that is distinct from other entities. All the natural objects, living things, and human artifacts among which we live are different types of societies. In 'democratic' societies such as stones and trees, all members cooperate but no one takes a leading role. But in some societies a guiding or determining function is taken by one part called a 'dominant' or 'monarchial occasion.' In higher animals this center is consciousness, and in humans it is the ego, mind, spirit, or personality." Cooper, Panentheism, 171. Cf. Alfred North Whitehead, Process and Reality, An Essay in Cosmology; Gifford Lectures Delivered in the University of Edinburgh Euring the Session 1927-28 (New York, Cambridge, Eng.,: The Macmillan Company; University Press, 1929), 127-167.

65 “Thus 'the nature of God is dipolar. He has a primordial nature and a consequent nature.' But unlike other entities, God is all-comprehensive. His primordial nature includes all ideal possibilities and is therefore free, complete, primordial, eternal, actually deficient, and unconscious.' His consequent nature prehends the entire universe of actual occasions and their entire past. Thus it is 'determined, incomplete, consequent, everlasting, fully actual, and conscious.'" Cooper, Panentheism, 174; Whitehead, Process and Reality, 524. 
their best actualization. The consequential nature of God would be the realization of other potential entities into actualization, whether they accept the initial aim God originally had in mind for them or not.

In a sense the Platonic dualism of actualized forms still plays a role in this dipolar God, yet the God of Whitehead is much more the world-soul, including all occasions within himself; and yet, in an abstract sense, he is transcending all the other societies of occasions, pulling them towards his cumulative will. ${ }^{66}$

Salvation is found by the different entities following the lure of God to reach their actualized potential. ${ }^{67}$ The problem of evil is addressed in this process philosophy as simply part of the process, when an entity chooses not to follow the primordial will of God and becomes part of the consequential or concrete nature of God. The evil that this entity has chosen is only part of God's experiential consequential nature and not a part of his intentional or primordial nature. There is no moral evil within God's transcendent intentional essence — only within his sympathetic responsive nature.$^{68} \mathrm{God}$ is therefore not responsible for evil but simply adapts to what has occurred to once again attempt to

66 "Indeed, Whitehead's whole ontology is a footnote to Plato. Like Plato, Whitehead posits two realms or dimensions of reality: the actual (the universe of "actual occasions") and the possible ("the realm of eternal objects"). Like Plato's, Whitehead's God holds them together. But Whitehead's God is not Plato's Mind or Craftsman, generating a Soul to exemplify the ideal Forms in the material world. For Whitehead, there is no actual eternal realm. His God is much more a World-Soul whose mind continually thinks of universal possibilities for the actual world." Cooper, Panentheism, 172. Cooper also points out that the students of Whitehead, like Hartshorne, more fully developed the difference between pantheism and panentheism, showing that there is a freedom within the choices that individuals can make, by not moving towards the lure of God's primordial will. This for Cooper is a clear demonstration of the modern panentheism of personal individual freedom of the beings within God. Cooper, Panentheism, 185.

${ }^{67}$ Cooper, Panentheism, 175. Whitehead, Process and Reality, 525-526.

${ }^{68}$ David Ray Griffin, "John B. Cobb, Jr.: A Theological Biography," in Theology and the University: Essays in Honor of John B. Cobb, Jr, ed. David Ray Griffin (Albany, NY: State University of New York Press, 1991), 45-46. 
persuade the person toward his vision of their better actualization. ${ }^{69}$ Divine indwelling then is mutual as occurrences participate in the past, present, and future of other occurrences that then continue to actualize their potential, hopefully moving towards God's ultimate will for them.

Cobb directly ties Whitehead's philosophy in with his views on the divine-human indwelling in his commentary on Romans. This is especially evident when Cobb considers the theme of mutual immanence, listed in the introduction as well as in his chapter discussing Romans 6:1-8:39. ${ }^{70}$ Cobb develops the mutual immanence ideas of Whitehead to explain the Christological understanding of Jesus. Cobb compares the primordial will, as described by Whitehead, to the Greek logos used in Scripture. When an individual is open to the logos of God, such a one becomes incarnated by the logos and is considered to be Christ to a certain degree. ${ }^{71}$ In the history of humanity, Jesus was

69 "Because God's ideals are good, any deficiency or evil actualized in the world is not his doing. Yet God always aims to improve things by continually comprehending the world in terms of his ideal values. 'This transmutation of evil into good enters into the actual world by reason of the inclusion of the nature of God, which includes the ideal vision of each actual evil so met with a novel consequent as to issue in the restoration of goodness.' God does not cause or prevent instances of evil, but he tries to make the best of them by viewing them in his own vision of the greater good. Thus 'evil becomes a stepping stone in the all-embracing ideals of God." Cooper, Panentheism, 174.

70 John B. Cobb and David John Lull, Romans, Chalice commentaries for today. (St. Louis, MO: Chalice Press, 2005).

${ }^{71}$ Wheeler shows the lack of differentiation between Christ and the Spirit in Process thought. "The immanence of God in Jesus as the Christ (= Logos in Cobb's Christ in a Pluralistic Age) and the immanence of the Holy Spirit in believers as the basis of sanctification and Christian unity are systematically differentiated in accordance with Trinitarian theology in traditional Christianity. In process thought there is no systemic reason for making this differentiation. 'Logos' and 'Spirit' would simply be two historically attested metaphors for describing divine immanence.” David Ray Griffin, John B. Cobb, and Clark H. Pinnock, eds., Searching for an Adequate God: a Dialogue Between Process and Free Will Theists (Grand Rapids, MI: W.B. Eerdmans, 2000), 123-124. Marjorie Suchocki explores the possibilities that the Holy Spirit may be the transformation of the Logos realized in the world. "Insofar as we instantiate that aim, the Spirit is born in us, becoming one with us in the creation of community. In other words, Christ offers creative transformation; the Spirit is creative transformation realized in the world. In this case, of course, the Spirit is not manifest as Spirit per se, but only in 'works of mercy,' or the unitive work of God with us in history." Marjorie Suchocki, "John Cobb's Trinity: Implications for the University," in Theology and The University: Essays in Honor of John B. Cobb, Jr, ed. David Ray Griffin(Albany, NY: State University of New York Press, 1991), 159. Cobb himself makes the connection of the Spirit with the 
the most open to the will of God in his life; therefore, he is called the Christ. But Jesus is only different from us in degree rather than kind; other humans can also be the incarnation of the logos by accepting this creative will in their lives. ${ }^{72}$ Divine indwelling of humans for Cobb seems to be related to the submission of humans to the primordial will or the divine.

In summary, this historical background demonstrates the scope of the different understandings concerning the ontological nature of the divine indwelling of humans from the early church fathers to John Wesley and then from John Wesley (at the beginning of Modern theology) to the process theology of John Cobb. This provides the context for Wesley's choice of a classical theistic understanding of the ontological nature of the divine-human indwelling, through a body/soul dualism, and Cobb's choice of a process-dipolar panentheistic understanding of the nature of the divine indwelling of humans.

\section{Statement of the Problem}

This dissertation addresses the problem of the conflicting views of the ontology of divine-human indwelling that have been manifested in the contributions and limitations of the models proposed by John Wesley and John Cobb.

Kingdom of Heaven. “. . . One step toward a solution would be to identify Spirit in its transcendent character as the resurrection of the dead or the Kingdom of Heaven. The justification is that the Spirit is regarded in Christianity as an eschatological phenomenon; it points to the End to which we move That End is God as the resurrection or Kingdom. The immanent presence of the Spirit now is anticipatory of that End, assuring us of it and uniting us with it. The Trinity can then be God, his Logos, and his Kingdom. The Logos is present with us as Christ; the Kingdom, as Spirit.” John B. Cobb, Christ in a Pluralistic Age (Philadelphia: Westminster Press, 1975), 261-262. Cooper discusses the possible interpretations of the Trinity for John Cobb and David Griffin in a similar fashion. Cooper, Panentheism, 189.

${ }^{72}$ Cobb believes that the difference in degree is substantial enough that it constitutes Jesus as a different kind of Christ. This will be more developed in Chapter 3 of this dissertation. Cobb, Pluralistic Age, 140-142. 


\section{Purpose of the Research}

The purpose of this research is to survey and analyze the writings of Wesley and Cobb, in order to present their models of the ontological nature of the divine-human indwelling. In addition, an effort will be made to evaluate their models, based on their interpretations of Romans 6-8, to determine whether their ontological models of divinehuman indwelling are supported by the interpretations of representative scholarship.

\section{Justification}

The justification for this study is two-fold. First, as presented in the historical background, there are two overarching models concerning the ontological nature of the divine-human indwelling; either essential-substantial union of the divine with the human soul or the dipolar-process panentheistic encompassing of the cosmos within the being of the consequential nature of the divine. Second, a belief system, which affirms a holistic understanding of theological anthropology, as well as an independent personal ontology of God, would appear to be at odds with either of the previously mentioned models of the divine indwelling of humans. ${ }^{73}$ The hope for this study is that the evaluation of Wesley

${ }^{73}$ The Adventist system of theology is one example, which affirms both holistic theological anthropology and an independent personal ontology for God. Adventism rejects any dualistic nature of humanity. The body and breath make up the living soul according to Genesis Chapter 2. The soul is not separate from the body; therefore the classical transcendent union of God with the soul is not possible. In his soon to be published article, Richard Davidson points out (drawing on insights from F. LeRon Shults) that, "'in the last two centuries, biblical scholars have increasingly moved toward a consensus that both the Hebrew Bible and the New Testament provide a holistic model of the human person." Davidson then continues to explain the holistic relationship of the body and soul. Humans do not have a soul, rather they are a soul and humans do not have a body they are a body. This article will be published as a part of book published by the Biblical Research Institute. Richard Davison, "The Nature of the Human Being from the Beginning: Genesis 1-11," in "What Are Humans Beings That You Remember Them?" Proceedings of the Third International Bible Conference, Nof Ginosar and Jerusalem, June 11-21, 2012, ed. Clinton Wahlen(Silver Spring, MD: Review and Herald, 2015), 13. There is further evidence for this position in both the Theological Wordbook of the Old Testament (TWOT) and the Theological Dictionary of the New Testament (TDNT), as both describe the soul from a holistic point of view, including physical, mental, emotional, and moral concerns. "It must not be concluded from this study of nepeš that the [Old Testament] (OT) presents man as physical only. There are other OT ideas to be considered in this connection: (1) the OT teaching concerning the "spirit" of man; (2) the OT teaching concerning the heart (lēb) of man; (3) the 
and Cobb's models may provide a first step forward in the canonical work that may need

to be done to construct a biblical model that would answer some of these objections.

Therefore, there may be a need for a third model of the ontological nature of divine-

human indwelling.

\section{Method}

The method for this research will include the following: Chapter 1 consists of an

introduction and historical background. Chapters 2 and 3 will present a survey and

analysis of the writings of both Wesley and Cobb, in order to describe their models of

divine-human indwelling. ${ }^{74}$ This will be done using the following three categories:

subject of the image of God (see șelem) in man; and (4) the picture as given of man's relation to God."

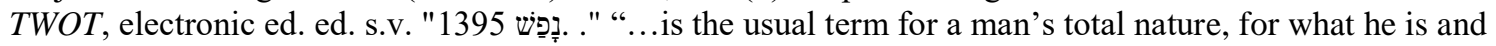
not just what he has. This gives the term priority in the anthropological vocabulary, for the same cannot be said of either spirit, heart, or flesh. The classical text in Gn. 2:7 clearly expresses this truth when it calls

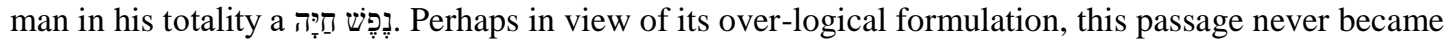
normative for the OT as a whole." TDNT, electronic ed. ed. Ellen White, in her response to John H. Kellogg, also rejects the pantheistic/panentheistic perspective. She wrote some very distinct definitions of the personhood of God and humans in the eighth volume of her Testimonies. She clearly states that John 17 is an example of the unity of the Godhead, being united in will and purpose but not in person. "The unity that exists between Christ and His disciples does not destroy the personality of either. They are one in purpose, in mind, in character, but not in person. It is thus that God and Christ are one." She emphasizes a personal God, distinct from his creation. Ellen G. White, Testimonies for the Church, 1-9 vols., vol. 8 (Battle Creek, MI: Steam Press of the Review \& Herald Office, 1904), 269. Norman Gully expresses the same necessity for the personhood of all three divine persons in the Trinity and provides multiple examples from theologians like Jürgen Moltmann, Douglas Kelly, Gordon Lewis, and Bruce Demarest. For Gulley the three persons of the Trinity are united in an eternal interpersonal relationship of reciprocal love. This kind of Trinitarian theology does not allow for the panentheistic Trinity of wills presented by John Cobb and others in process theology. Norman R. Gulley Systematic Theology: God as Trinity. (Berrien Springs, MI: Andrews University Press, 2011), 3-6, 134.

${ }^{74}$ Wesley's entire body of works will be studied. Some of the specific sermons already engaged are: John Wesley, "The Sermons of John Wesley-Sermon 8: The First Fruits of the Sprit", Wesley Center for Applied Theology http://wesley.nnu.edu/john-wesley/the-sermons-of-john-wesley-1872-

edition/sermon-8-the-first-fruits-of-the-spirit/ (accessed November 20 2013); Wesley, "On the Holy Spirit."; John Wesley, "The Sermons of John Wesley-Sermon 138: On Grieving the Holy Spirit", Wesley Center for Applied Theology http://wesley.nnu.edu/john-wesley/the-sermons-of-john-wesley-1872edition/sermon-8-on-the-grieving-of-the-holy-spirit/ (accessed November 20 2013). Works of other authors on Wesley's theology will include Kenneth J. Collins, Randy L. Maddox, and Hoo-Jung Lee. Some of the works of Cobb that will be used in this research include: John B. Cobb, The Structure of Christian Existence (Philadelphia: Westminster Press, 1967); John B. Cobb, God and the World (Philadelphia: Westminster Press, 1969); Cobb, Pluralistic Age; John B. Cobb, Jr., "Strengthening the Spirit," Union Seminary Quarterly Review 30, no. 2-4 (1975); John B. Cobb, Jr., "Wholeness Centered in Spirit," in Spirit 
ontology of God, ontology of humanity, and ontology of the divine-human indwelling (these categories will be further discussed in the next section of this chapter), in order to evaluate whether these models of divine-human indwelling are biblically adequate.

Chapter 4 will compare and contrast Wesley's and Cobb's interpretations of Romans 6-8 as a focused scriptural lens, focusing on the final category of comparison, the ontology of divine-human indwelling. In Chapter 5, following the summary and conclusions regarding Wesley's and Cobb's models, the results of the discussion on Romans may then be used to suggest possible implications for moving towards a more biblical model for the nature of divine-human indwelling.

\section{Theoretical Framework}

There are three categories needed for the full development of a model concerning the ontological nature of divine-human indwelling. First, Wesley's theistic model presents a divine ontology, consisting of three ontological persons in one; while Cobb's panentheistic model presents dipolar all-inclusive divine-cosmic mutual indwelling. ${ }^{75}$ Second, the ontology of humanity within Wesley's theistic model is dualistic; having both a body and soul, while Cobb's panentheistic model for a human being is holistic. $\mathrm{He}$

Centered Wholeness Beyond the Psychology of Self(Lewiston, NY: Edwin Mellen, 1988); John B. Cobb, Grace and Responsibility: a Wesleyan Theology for Today (Nashville: Abingdon Press, 1995); John B. Cobb, A Christian Natural Theology: Based on the Thought of Alfred North Whitehead, 2nd ed. (Louisville: Westminster John Knox Press, 2007); John B. Cobb and David Ray Griffin, Process Theology: An Introductory Exposition (Philadelphia: Westminister Press, 1976); Cobb and Lull, Romans; John B. Cobb and Jeanyne B. Slettom, The Process Perspective: Frequently Asked Questions about Process Theology (St. Louis, MO: Chalice Press, 2003); John B. Cobb and Jeanyne B. Slettom, The Process Perspective II (St Louis, MO: Chalice Press, 2011). Others who engage Cobb's theology and understanding of ontological union and who also discuss his Trinitarian views, are: Griffin et al., eds., Searching for an Adequate God: a Dialogue Between Process and Free Will Theists; Gordon R. Lewis and Bruce A. Demarest, Integrative Theology, vol. 2 (Grand Rapids, MI: Zondervan, 1996); Suchocki, "Cobb's Trinity."

${ }^{75}$ George Pattison, God and Being: An Enquiry (Oxford, New York: Oxford University Press, 2011). Peckham, "Concept of Divine Love". 
or she is only one substance, body and soul combined. ${ }^{76}$ Finally, the ontology of divinehuman indwelling, for Wesley's theistic model, requires the combination of the knowledge (presented in the previous two categories) into an understanding of God who is distinct from the world, outside of time and space, yet who through the Holy Spirit indwells the soul of the human being through substantial union. ${ }^{77}$ In contrast, when the understanding from the first two categories are combined for Cobb's panentheistic model, divine-human indwelling is a co-constitutional participation of mutual immanence, through the openness of individuals within the being of God to be incarnated by his transcendent creative will. ${ }^{78}$ Both of these options fall within the definition of ontological indwelling used for this dissertation. Wesley's more classical system is the interpenetration of the divine being/reality within the being/reality of the human soul. Cobb's panentheistic system is the experiential intermingling of the divine/human realities. $^{79}$

It is important to define the how ontological nature of divine-human indwelling will be used for this dissertation. When ontology is referred to in this dissertation it is the being/reality of the thing itself, or the is-ness of that thing. Therefore, when the ontology of God is referred to the discussion will be about the reality/being of what God is. Is God

76 There are Christian systems of theology that do not accept a panentheistic view of cosmology which also support a monistic view of the ontology of humanity. Warren S. Brown, Nancey C. Murphy, and H. Newton Malony, Whatever Happened to the Soul?: Scientific and Theological Portraits of Human Nature, Theology and the sciences. (Minneapolis: Fortress Press, 1998). Davison, "Nature of the Human Being."

${ }^{77}$ Gleason, Indwelling Spirit.

${ }^{78}$ Cobb and Lull, Romans.

${ }^{79}$ One of the common characteristics of panentheism noted by Brierley is "the language of "inextricable intertwining," which affirms at least some level of the intermingling of being in most panentheistic systems. Brierley, "Naming a Quiet Revolution," 12-13. 
more transcendent or immanent, timeless or temporal, and a Trinity of persons or natures?

In the same way, the ontology of humanity will be asking about the reality/being or is-ness of what it means to be human. Is the being of a human a dualistic union of body and soul or a holistic, non-substantial, organization of occasions? Once the ontology or realities of the divine and human have been determined in a particular system of theology, (specifically, John Wesley's and John Cobb’s systems for this dissertation.) Then the ontological nature of the divine-human indwelling of those two realities can be expressed.

The nature of indwelling will be considered ontological if the two realities/beings of the divine and human are united in some way through the intermingling or interpenetration of being. It may be possible to define ontological indwelling in other ways. This dissertation will be using the term ontological in specific relation to the definition above, which has been the historical way of understanding the ontological discussion of divine-human indwelling.

For the purpose of clarity it is also helpful to offer a working definition of panentheism for this dissertation. There are many different ways to understand what theologians mean by panentheism. In general the definition of the word itself offers a common ground to start from. Pan, meaning all, en, meaning in, and theism, meaning God. Therefore, in some way panentheism is defined as all of reality being within God and perhaps God being within all of reality. The discussion around this terminology however is greatly varied.

These varieties are addressed in several different ways in the book In Whom We 
Live Move and Have Our Being: Panentheistic Reflections on God's Presence in a Scientific World. Brierley offers eight different common themes that are accepted to different degrees in panentheistic thought: "the cosmos as God's body; language of 'in and through'; the cosmos as sacrament; language of 'inextricable intertwining'; the dependence of God on the cosmos; the intrinsic, positive value of the cosmos; possibility; and degree Christology. These features can be applied as a test to theologians to see whether or not they can be described as panentheist." There is much discussion amongst theologians claiming panentheism concerning these different categories and many are in direct contradiction with the others. Brierley, however, finishes with this conclusion: “...panentheism can be defined as the doctrine of the cosmos being the good (against Clayton) ‘body' (against Peacocke), or 'sacrament,' needed by God (against Clayton), with which God is inextricable intertwined, and 'in and through' which God works and suffers. The doctrine involves a degree Christology." ${ }^{" 80}$

It might be safe to say that it is difficult to find a clear definition of panentheism. Gergersen offers three general categories of panentheism, the first is soteriological panentheism expressed in relationship to the eastern orthodox Trinitarian theology. The second is, expressivist panentheism in the context of German Idealism. The third, is dipolar or Whiteheadian panentheism. ${ }^{81}$ For this dissertation I will simply choose the variety of panentheism that is directly related to the panentheistic theologian within the study. John B. Cobb Jr. is a process theologian holding to the Whiteheadian expression of a dipolar panentheism.

\footnotetext{
${ }^{80}$ Brierley, "Naming a Quiet Revolution," 6, 12-13.

${ }^{81}$ Gregersen, "Three Varieties."
} 
This will be further discussed in Chapter 3 of this dissertation, but for now the basic characteristics include a dipolar God with a transcendent essential primordial nature that is distinct from the cosmos and an immanent consequential or concrete nature which is all inclusive of the experientially based reality of the entire cosmos. I, therefore, return to the basic definition of panentheism, all is within God experientially in the consequential nature of God and yet God is beyond all in an essential nature. Through this essential nature, God lures all of the cosmos to incarnate his primordial will into their reality/being thus becoming Christ by degree and participating in the co-constitution of the divine being. ${ }^{82}$

\section{Scope and Delimitations}

The scope of this study includes the comparison of Wesley's and Cobb's models of the divine indwelling of humans, for the purpose of engaging the wider scholarly conversation and an evaluation of their models, based on representative scholarship of the singular scriptural passage of the Romans 6-8. ${ }^{83}$ The "representative" scholars referred to in this dissertation are critical-exegetical representatives of various faith traditions. The selection process was done through an organic survey of commentaries on the book of Romans for those who most relevantly addressed the ontological concerns of this

\footnotetext{
${ }^{82}$ For a fuller account of process panentheism Cf. Griffin, "Panentheism."

${ }^{83}$ Using Scripture to deconstruct the previous models is the hermeneutical method, which allows theologians to construct a system of theology based on biblical presuppositions, rather than those of philosophical thought. Canale gives the demonstration of the macro hermeneutical level of biblical interpretation, which shows the presupposition of the timelessness of God, developed from Greek philosophy, rather than an eternal-temporal biblical understanding of God. Through this example he calls for the deconstruction of all theological systems based on Scripture so that biblical interpretation on the macro level can actually be derived from Scripture as the phenomenal thing itself to be studied. Fernando Luis Canale, "Deconstructing Evangelical Theology?," Andrews University Seminary Studies 44, no. 1 (2006).
} 
dissertation. For these reasons the following scholars have been engaged in this study:

James D.G. Dunn (Church of Scotland; Methodist); Joseph A. Fitzmyer (American

Catholic Priest/Society of Jesus); Earnest Kasemaan (Lutheran); Richard N. Longenecker

(Evangelical); Douglas J. Moo (Evangelical); and Thomas R. Schreiner

(Evangelical/Baptist). ${ }^{84}$ The delimitations of this study require a focused study of

Romans 6-8, even though a full canonical study is required in order to do a full

deconstructive evaluation and/or construction for any biblical model, this would be too much to attempt in a single dissertation. ${ }^{85}$ Because of the lack of a full canonical study, only suggested implications toward a model of the divine indwelling of humans can be made. This dissertation will also only deal with the ontological nature of divine-human indwelling. It will not discuss the ontological nature of the union between the members of the Trinity nor will it discuss the ontological nature of the incarnation except in general reference to divine-human indwelling.

\footnotetext{
${ }^{84}$ For more on the rationale and choice of these scholars reference the discussion in the footnotes and evidence presented in Chapter 4 of this dissertation.

85 See: John C. Peckham, "The Analogy of Scripture Revisited: A Final Form Canonical Approach to Systematic Theology," Mid-America Journal of Theology 22, (2011).
} 


\section{CHAPTER 2}

\section{JOHN WESLEY'S UNDERSTANDING OF THE ONTOLOGICAL NATURE OF DIVINE-HUMAN INDWELLING}

\section{Introduction}

In this chapter, John Wesley's interpretation of the ontological nature of divinehuman indwelling will be described and analyzed, based on the categories of comparison outlined in the method section of Chapter 1. Preceding the development of these categories, there will be an introductory section concerning the historical-theological background to Wesley's theology of indwelling, which may lend a better understanding of Wesley's relationship to his classical sources. Following this background, Wesley's views on the categories of the ontology of God, the ontology of humanity, and the ontology of divine-human indwelling will be explored, with identification of the markers of classical theism in each section. Finally, in the summary and conclusion of this chapter, a concise presentation of the findings from the chapter will help to pinpoint Wesley's interpretation of the ontological nature of divine-human indwelling, as representative of the classical theistic understanding, in contrast to John B. Cobb Jr.'s panentheistic model, which will be presented and evaluated in Chapter 3.

\section{John Wesley's Biographical Sketch and Theological Method}

This historical-theological background will cover the elements of Wesley's life 
and study which shaped his interpretation of the ontological nature of divine-human indwelling. The largest factor influencing his interpretation is that, while he held to the primacy of Scripture as the source and rule of faith and practice for the Christian:

Wesley insisted that no one reads the Bible alone. That is everyone reads more than the Bible (whether they know it or not), and everyone interprets the Bible (whether they are aware of it or not)... .Proper biblical interpretation and theological method combine absolute submission to the Bible as God's inspired Work with respect for the Great Tradition of Christian teaching, a reasonable mind that uses logic and a warm heart and mind illumined by the Holy Spirit. ${ }^{1}$

Wesley's acceptance of a quadrilateral of theological sources-including

Scripture, tradition, experience, and reason—provides a helpful framework for presenting his historical-theological background. Wesley's theology developed in conjunction with his personal spiritual experiences, which drove him to find understanding in the vast resources he accessed as an Oxford trained scholar of the Anglican Tradition. The presentation of Wesley's background in subsequent sections of this chapter will start with his spiritual experience, move to his value for tradition, followed by his use of reason, and, finally, the impact of these on his scriptural interpretation.

\section{Wesley's Spiritual Experience}

Wesley grew up in an Anglican home and was educated at Oxford. After receiving orders from the Anglican Church, he accepted the challenge of going as a missionary to Georgia in North America. His time there was short and some have said a failure. ${ }^{2}$ The real significance of this part of his life was the journey to Georgia on the

\footnotetext{
${ }^{1}$ Roger E. Olson, The Story of Christian Theology: Twenty Centuries of Tradition \& Reform (Downers Grove, IL: InterVarsity Press, 1999), 513.

${ }^{2}$ Olson, Story of Christian Theology, 510.
} 
ship with Moravian Christians during a storm. Wesley was so fearful for his salvation that he had no peace on that voyage, while all around him he witnessed the Moravian believers experiencing a calm assurance. Wesley's theological education had been one of cold intellectualism, which some have called an "Arminianism of the head." 3 There was little or no heart connection to the orthodox acceptance of doctrine. Following his return voyage from Georgia, Wesley had a life changing experience at a religious meeting on Aldersgate Street in London, when he felt his heart "strangely warmed." Wesley longed for the assurance which the Moravians had, and yet he sensed that their experience-based theology was too strongly based on enthusiasm, which he distanced himself from. ${ }^{5}$ These experiences drove him back to his studies to find a better understanding of the growing process of sanctification in the life of the believer. It was through this study that he discovered the importance of the Holy Spirit. ${ }^{6}$

\section{Wesley's Respect for Tradition}

Wesley had great respect for the Tradition of the church. This included the writers of Christian antiquity such as Clement of Rome, Ignatius, Polycarp, Tertullian, Origen, Clement of Alexandria, Cyprian, Chrysostom, Basil, Ephrem Syrus, and Macarius. ${ }^{7}$

${ }^{3}$ Olson is quoting Alan P. F. Sell. Olson, Story of Christian Theology, 510.

${ }^{4}$ Olson, Story of Christian Theology, 511.

${ }^{5}$ Kenneth J. Collins, John Wesley: A Theological Journey (Nashville, TN: Abingdon Press, 2003), $56-58,86-89,100$.

${ }^{6}$ Randy L. Maddox, Responsible Grace: John Wesley's Practical Theology (Nashville, TN: Kingswood Books, 1994), 125-126.

${ }^{7}$ Thomas C. Oden, John Wesley's Teachings, vol. 1 (Grand Rapids, MI: Zondervan, 2012), 83. Outler also identifies the various sources of Wesley theology in his introduction to The Works of John Wesley. In the section headings of this article alone, Outler follows Wesley beginning with Scripture and moving through The Classics, Christian Antiquity, Anglican Scholars, the Church Fathers through the English Reformation, his own Anglican and Puritan Tradition, and Contemporary Culture. Wesley, Works, 
Wesley defined the earliest of these writers as the purest sources of Christian tradition. ${ }^{8}$

His sources of tradition also extended from the church fathers to the creeds of the

Westminster confession and many founders of the Anglican tradition. He also studied the early Christian writers as scriptural exegetes. ${ }^{9}$

For the focus on Wesley's understanding of indwelling, however, the strongest

sources were the Eastern Church Fathers. Albert C. Outler has suggested, following the line of Werner Jaeger's conclusion, that Gregory of Nyssa was the primary source for Wesley's spirituality. ${ }^{10}$ But Hoo-Jung Lee, citing the work of Reinhart Staat, shows that Macarius the Egyptian is the most prominent source for both Gregory of Nyssa and Wesley. ${ }^{11}$ I accept Lee's line of reasoning and will, therefore, spend the greatest amount

$66-96$.

${ }^{8}$ Oden, Wesley's Teachings, 88-89.

${ }^{9}$ Oden, Wesley's Teachings, 84-85.

${ }^{10}$ Lee, "New Creation", 158. Outler clearly declares, concerning Wesley, that "His central theme (divine-human participation) was learned in large part from Macarius, Gregory of Nyssa, and Ephrem Syrus. His concept of Christian koinonia was more Greek than Latin, and this explains his freedom to correct what he regarded as the excessive sacerdotalism within the Anglican ecclesiology that he had inherited. At the center of all these ideas was his understanding of the person and work of the Holy Spirit as God's personal presence in the believer's heart and will and in the Spirit-filled community and its sacraments. This enabled him to think of the Christian believer as indwelt and led by the Spirit within, rather than being possessed by the Spirit as if by some irresistible force." This is taken from Outler's Introduction to Wesley, Works, 74-76.

${ }^{11}$ While Jaeger's interpretation is that Macarius was using the material of Gregory to develop his homilies, Staat points out and Lee agrees that Gregory was actually the one making use of Macarius. One of the points made for this argument is that Macarius' was a scriptural theologian, which requires him to be solely based on Scripture and therefore would not allow him to use another's work. A second point in the argument shows likely grammatical errors in Gregory's use of Macarius. Finally, Robert S. Brightman, who is a supporter of Gregory of Nyssa, recognizes against his hope that Wesley does not rejoice in Gregory the way he should if Gregory had been Wesley's primary source, rather than Macarius. "'In the light of Wesley's great admiration for the Spiritual Homilies of Macarius, and the affinity of Wesley's thought with Macarius, it becomes clear that the conclusion...that Wesley did not have any extensive knowledge of Gregory of Nyssa is reinforced. For the present study has shown that there is a significant affinity between Wesley and Gregory, and if Wesley responded to Macarius as he did it seems to be inevitable that he would have responded with at least as much enthusiasm to Gregory. . . If Wesley sang while reading Macarius, after reading Gregory he would have shouted!'” Lee, "New Creation", 174-176, 
of time in this part of the historical background on Macarius' understanding of

indwelling.

Marcarius the Egyptian, also known as Marcarius the Great, was an ascetic monk

and is now recognized as an eastern father. He was born c. 300 and lived to the age of 90;

60 of those years he spent in the desert. ${ }^{12}$ He wrote a collection of 50 spiritual homilies

which were included in Wesley's library. The center of Macarius' spirituality was the

personal experience of the Holy Spirit in the innermost place of the soul - the heart. ${ }^{13}$

The basis of this inner spirituality is tied in with Macarius' view of anthropology. Human

beings have an immortal soul, which is born as neutral towards good and evil. The soul

then has a free moral choice whether it will mix with light or darkness, good or evil.

Once the soul was mixed with the darkness of sin it inherits condemnation. ${ }^{14}$ Left

177.

12 D.D. A. J. Mason, Fifty Spiritual Homilies of Marcarius the Egyptian, ed. D.D. W. J. SparrowSimpson, W. K. Lowther Clarke, B.D., Translations of Christian Literature (London; NY: Society for Promoting Christian Knowledge, 1921), i-vi.

13 "Macarius' spirituality has been regarded as one of the most important aspects of Eastern spirituality in its monastic form. It represents the spirituality of the heart in contrast to the spirituality of the intellect (nous) inculcated by Evangrius Pontious. For Macarius, the center of our spiritual life is the inner depths of the soul (heart), and the spiritual sensible experience of prayer only matters in this innermost life. Only by constant prayer can the human being be in tune with God as Spirit through the operation of his grace. And only through this personal awareness of Spirit, the contrary experience of Evil can be overcome. In this regard, the theology of the Macarian Homilies offers the most impressive pneumatology that seems to be grounded in his personal experience of the Holy Sprit." Lee, "New Creation", 181.

14 “" Do not slightly regard the intellectual nature of the soul. The immortal soul is a vessel of great price. . . Behold they own worth and high descent that the Lord should come on an embassy, and that not by angels, but in his own person, on purpose to recall thee that hast been lost, and to restore to thee the original formation of Adam in his purity. For man was Lord of all, from heaven above to the depths beneath, and pure from sin, (the image) and likeness of God.' However, Macarius also insists that the human soul was created neutral or in its nakedness, in the sense that it can now choose — or mix withgood or evil, light or darkness, according to free will, having fellowship with Satan or the Spirit of God: 'It remains then that whatsoever the soul mixes with, the same is united to in every motion of the will. If therefore, it was the light of God within itself and liveth therein, it belongeth to the light of rest; or if it has the darkness of sin, it inherits condemnation.' Thus original freedome in human nature also presupposes the possibility of the Fall." Lee, "New Creation", 182. Notice the emphasis of free choice in this as well. Wesley's Arminianism also fits well with this part of Macarius' theology. 
"without Christ, the Master, dwelling in it, the soul becomes a wilderness"15 and is under the dominion of Satan. Only through the surrender of the soul to the light and power of the Holy Ghost can the soul return to the light. ${ }^{16}$ God comes from without only through grace, which works its effect on the innermost heart of the individual. Macarius emphasized the new birth by the spirit in order for the soul to be free from sin. Although Macarius called the soul immortal, he spoke of the soul as able to die without the Divine nature from the Spirit. Without the Divine Spirit the soul is not worthy of "the eternal life of the Godhead. ${ }^{17}$

It is also significant that Macarius held to the "Holy Trinity" as involved in divine-human indwelling. ${ }^{18}$ Macarius used many metaphors to express this Trinitarian indwelling of the soul. He clearly saw the human soul as separate from the creator, as the creature and the workmanship from the workman and yet "it has pleased him (God) to dwell in this work of his hands" as his own "mansion-house," his own bride. ${ }^{19}$ In addition, it is through the Spirit that Christ's "luminous glory" can penetrate the soul and

\footnotetext{
${ }^{15}$ Lee, "New Creation", 183-184.

${ }^{16}$ Lee, "New Creation", 182-183.

${ }^{17}$ Lee, "New Creation", 184.

${ }^{18}$ Lee, "New Creation", 186.
}

${ }^{19}$ For Macarius grace and the indwelling of the Spirit are inseparably tied together. "Thus we arrive at the core of Macarius' theology of grace, centered in the indwelling and communion of the Holy Spirit that is impossible without the boundless, inexpressive compassion of God, which alone can overcome the infinite gap between Creator and creature: 'This is the Lord; she (human soul) is servant. This is the Creator; she a creature. This is the Workman; she the workmanship. There is nothing in common to both natures. But through his boundless, ununtterable, and inconceivable love and tender compassion, hath it pleased him to dwell in this work of his hands, his precious and choice work, 'that we might be a kind of first-fruits of his creatures.' For his wisdom and fellowship, for his own mansion-house for his own precious pure Bride."” Lee 186. Lee also mentions Ephraem as an eastern influence on Wesley, as do several other scholars. Ephraem, according to Lee, seeks to "fully preserve the ontological gap between Creator and created.” Lee, "New Creation", 217. 
become the "true Charioteer who rides upon the throne of the transformed soul

'governing it with the reins of the Spirit, and directing her in the way as he sees best." 20

The Christology of Macarius "is empowered by and oriented towards his strong

pneumatology." 21 Therefore, the Spirit of Christ is the "real subject of salvation" rather

than a simple will or force of God working in the souls of individuals. ${ }^{22}$

For Macarius, the nature of the human union with the Godhead through the

indwelling of the Holy Spirit was a substantial abiding through which the soul is able to

be face-to-face with God. ${ }^{23}$ The Spirit becomes thoroughly united to the soul by grace. ${ }^{24}$

The eschatological effect of this union is the glory of the Holy Spirit within the soul,

which will eventually shine from the soul through the body, transforming it into a

Spiritual body. ${ }^{25}$

\footnotetext{
${ }^{20}$ Lee, "New Creation", 186.

${ }^{21}$ Lee, "New Creation", 186.

${ }^{22}$ Lee, "New Creation", 186.
}

${ }^{23}$ Lee, Quoting Macarius: "“Christians therefore are lights that have the oil in themselves that is, 'the fruit of righteousness.' But if they are not lighted up from the light of the Godhead in themselves, they are nothing; the Lord was a burning light through the Spirit of the Godhead abiding substantially in him, and inflaming his heart according to his human heart."” Lee, "New Creation", 192-193.

${ }^{24}$ This understanding of grace as the substantive means by which the Holy Spirit indwells the soul is one still used in the current discussions. Robert W. Gleason, for example, agrees with his assessment of De la Taille that the soul is substantially united with the created accident of Grace so that the uncreated act, who is God, can then indwell the soul. Grace as the created act is the substantial union, but it cannot be done without the presence of the uncreated act, therefore God is truly present in the soul of the believer through Grace. "Grace is an accidental form which is newly actuated in the soul by the divine indwelling. It is a created actualization of an obediential potency of the soul. But its entire nature as a created accidental form consists in its being a modification of the soul by which the soul actually receives in a created, accidental way the substance of God thus present and communicating himself. God's presence therefore can be understood in terms of a quasi-formal causality. God, the Uncreated Act, by his presence, actuates the obediential potency of the soul to receive him. The actuation of this potency and grace are identical. Grace is the created actuation according to which the actuating Uncreated Act is received in created form.

Between God, the Uncreated Act, and grace, his created reception, there is no intermediary. Grace is a formal modification of the soul." Gleason, Indwelling Spirit, 82.

25 "The goal of perfection presupposes the foretaste of the world to come in the present spiritual life. Glory of the coming age is not separable from the present experience of the Spirit since the Spirit can 
Macarius is recognized as the eastern writer with the most influence on Wesley, which is demonstrated in several (possible) ways. Macarius claims to solely depend on Scripture and Wesley also has a great dependence on Scripture. ${ }^{26}$ Wesley's understanding of the soul as immortal (excluding Marcarius' neutrality of the soul), and the work of grace through the Spirit towards an ultimate telos of perfection, is similar to that of Macarius. The emphasis on the new birth in Macarius is also evident in Wesley. ${ }^{27}$ Macarius and Wesley both see an awakening of the spiritual senses through the indwelling of the Spirit and a participation in the fullness of divine nature through the Holy Spirit. ${ }^{28}$ This will be more fully developed as this chapter continues.

The primary differences which Lee points to between Macarius and Wesley have to do with Wesley's logical English mind. Wesley does not accept the "symbolic way" of theological interpretation used by Macarius. ${ }^{29}$ Lee also suggests that Wesley's mind may have been logically married to his substantial view of evil, which would be removed in an instant when contrasted to the extended process of theosis in Macarius. The individual focus of Macarius does not seem to include the cosmic idea of New Creation that Wesley has, although Lee offers the possibility that this is because of the understanding of person

\footnotetext{
be properly called the Consummator of the whole divine dispensation. . 'there shooteth out from within the glory of the Holy Spirit, covering the bodies of the saints, which glory they had before, within hidden in their souls. For whatever (the soul) hath at present, the same cometh forth at that time outwardly in the body.' Thus for Macarius' spiritual vision the interior glory will burst forth exteriorly in the resurrection body." Lee, "New Creation", 201.

${ }^{26}$ Lee, "New Creation", 203.

${ }^{27}$ Lee, "New Creation", 204.

${ }^{28}$ Lee, "New Creation", 205-206.

${ }^{29}$ Lee, "New Creation", 208.
} 
and soul, which may be different in the historical settings of these two men. ${ }^{30}$

In summary, Wesley cedes a strong value to tradition. His work to translate many of the ancient works of Christianity, as well as his building of the Christian library, showed this clearly. On the focus of indwelling in Wesley, the Eastern Church Fathers have the most prominent place and Macarius most of all. There are many parallels between the two but according to some scholars Wesley's western logic might be part of what gets in his way from fully following the spirituality of Macarius. It is the historicaltheological influences on Wesley's use of logic that I shall turn to next.

\section{Wesley's Use of Reason}

Wesley saw reason as a gift from God and part of the make-up of human beings as they are made in the image of God. Wesley had a strong interest in the natural world, the sciences, and philosophy. ${ }^{31}$ In addition, he was thoroughly conversant with the classic Greek philosophers. Outler explains that Wesley saw the ongoing, tremendous effect of the Greco-Roman thought, even on his current culture and it was an "integral element in this theological perspective." ${ }^{\prime 2}$ Outler also demonstrates the effect of classic thought on Wesley's exegesis of some of his most "distinctive ideas (e.g., his participation theme, [and] his mind-body dualism...)." ${ }^{, 33}$ Once more, from Outler's introduction: "In Wesley’s own case this classical orientation was very much more that ostentation; it was an integral

\footnotetext{
${ }^{30}$ Lee, "New Creation", 208.

${ }^{31}$ Laura Felleman has written her dissertation demonstrating Wesley's use of natural philosophical phrases within his writing. Laura Bartels Felleman, "The Evidence of Things Not Seen: John Wesley's Use of Natural Philosophy" (Dissertation/Thesis, Drew University, 2004).

${ }^{32}$ Wesley, Works, 72-73.

${ }^{33}$ Wesley, Works, 72-73.
} 
element in his theological perspective. He knew how deeply classical culture had shaped patristic Christianity. He also knew how decisively even in his own time, its rediscovery was reshaping the emergent Enlightenment in Europe." ${ }^{34}$ It seems that Greek philosophy played a considerable role in shaping Wesley's presuppositions concerning the ontology of God and humans, which are necessarily a part of the ontological nature of indwelling. ${ }^{35}$

\section{Summary: Scripture Through Wesley's Filter}

Given the influences which have shaped Wesley's theology regarding the indwelling of the Holy Spirit, it is clear, as he admitted, that He did not read Scripture alone - that is, in isolation from other theological resources. His personal experience (in his historical context/culture) was the motivation for him to study other sources which also addressed his concerns for the assurance of his salvation and for bringing the life of the Spirit back into the cold intellectualism which Protestant orthodoxy had become. Macarius was the greatest influence on his pneumatology, including the indwelling of the Holy Spirit. In addition, Macarius shows evidences of presuppositions based on Greek philosophy, concerning the immortality of the soul, and therefore, the dualistic nature of human beings. These are also present in Wesley. Given his location as a Westerner, Wesley's reason operates along the patterns of Western logic. Further, Wesley's reason

${ }^{34}$ Wesley, Works, 72-73.

${ }^{35}$ Thomas C. Oden has written on the views of Wesley concerning the timeless view of God, largely referencing Wesley's sermon "On Eternity." While God does enter into time and space at particular moments he is outside of time and space, and past, present, and future are a perpetual now. In relation to the timeless God, Oden also expresses the dualistic understanding of Wesley's theological anthropology. The soul of a man is not eternal from the past as God is, but once the soul has been created it remains eternal even after the body dies. Oden, Wesley's Teachings, 35-40. 
operates in a way compatible with Greek philosophical presuppositions, such as the timelessness of God and the duality of humanity, which will be more fully explored in the rest of this chapter. ${ }^{36}$ Part of the task to be accomplished later in this research in Chapter 4, is to demonstrate how these presuppositions affected Wesley's definition of the ontological nature of indwelling, specifically with regard to his interpretation of Romans $6-8 .^{37}$

Now that Wesley's theological background has been explored, subsequent sections of this chapter turn to examining Wesley's writings in order to understand how he interprets the ontological nature of divine-human indwelling. This examination will engage the categories outlined in the method proposed in the first chapter of this dissertation. As such, this chapter presents Wesley's understanding of the ontology of God, the ontology of humanity, and finally, his interpretation of the ontology of divinehuman indwelling.

\section{The Ontology of God}

Wesley's description of the ontology of God provides a necessary foundation for understanding his view of the ontological nature of divine-human indwelling. In this section, Wesley's understanding of the attributes of God pertinent to this research will be

${ }^{36}$ Oden, Wesley's Teachings, 35-40.

${ }^{37}$ John D. Godsey, while tracing the use of Romans through Christian history, demonstrates the emphasis of John Wesley on the book of Romans. From his Aldersgate experience, following a reading of the book of Romans, to his sermons and notes being infused with ideas from Romans, it is not surprising that five of his first ten sermons were based on Romans. Three of these first five directly concern his theology of the Holy Spirit. "That Paul's thought in Romans was of central importance for Wesley's theology cannot be denied. Whether his interpretation is correct on all points may be disputed. Certainly in his context Wesley had to accent the great doctrine of the Spirit in Romans 8 and the holy life of the children of God that resounds in Romans 12-15." John D. Godsey, "The Interpretation of Romans in the History of the Christian Faith," Interpretation 34, no. 1 (1980): 12-14. 
discussed. These attributes include God as eternal and omnipresent, as a creator who is distinct from his creation, and as a Trinity of persons.

\section{God's Eternity and Omnipresence}

Wesley recognized the connection between time and space in relation to the ontology of God as demonstrated in God's eternity and omnipresence. For Wesley, God is infinite in duration as well as in space. ${ }^{38}$ Wesley understands God as an eternal being without beginning or end. It is God's lack of beginning that distinguishes him as divine. ${ }^{39}$ Other creatures, which God has made, may have never ending duration once they have been created, but God alone exists with eternal duration, without beginning. Eternal duration, at first glance, may look as though Wesley taught that God was temporal, but Wesley's definition of time does not allow for a complete temporality of God. Wesley describes time as a duration which has a beginning and an end. The beginning of time was at the creation of the world and its end will be when that creation comes to an end. Describing time Wesley says:

But is it not, in some sense, a fragment of eternity, broken off at both ends? - that portion of duration which commenced when the world began, which will continue as long as this world endures, and then expire forever? - that portion of it, which is at

38 "Nearly allied to the eternity of God, is his omnipresence. As he exists through infinite duration, so he cannot but exist through infinite space; according to his own question, equivalent to the strongest assertion,-- "Do not I fill heaven and earth? saith the Lord;" (heaven and earth, in the Hebrew idiom, implying the whole universe; ) which, therefore, according to his own declaration, is filled with his presence." Wesley, Unity of Divine Being, 265.

39 "To illustrate, Wesley appeals to and uses the distinction between "duration without beginning" and "duration without end" and maintains that while the former does indeed pertain to God alone, the latter characterizes creatures as well. He reasons: "This (duration without end] is not an incommunicable attribute of the great Creator; but he has been graciously pleased to make innumerable multitudes of his creatures partakers of it. He has imparted this not only to angels, and archangels, and all the companies of heaven, . . . but also to the inhabitants of the earth who dwell in houses of clay." In light of Wesley's reflections, it appears that eternity, conceived as duration without beginning" is especially descriptive of God, a divinemaking attribute if you will." Collins, Theology of Wesley, 23. 
present measured by the revolution of the sun and planets; lying (so to speak) between two eternities, that which is past, and that which is to come. But as soon as the heavens and the earth flee away from the face of Him that sitteth on the great white throne, time will be no more; but sink forever into the ocean of eternity! ${ }^{40}$

For Wesley, as demonstrated in the quote above, the duration of eternity is not an unending series of sequential events from eternity to eternity in the same way that current time is measured. Eternity is differentiated from the current understanding of time and could, therefore, be called timelessness or the Platonic antithesis of time. Wesley says that for God eternity could be called "the perfect entire possession of never-ending life." ${ }^{41}$ God fully knows the past, present, and future, because he dwells in them all as an eternal now.

"For, if we speak properly, there is no such thing as either foreknowledge or after knowledge in God. All time, or rather all eternity, (for time is only that small fragment of eternity which is allotted to the children of men,) being present to him at once, he does not know one thing before another, or one thing after another; but sees all things in one point of view from everlasting to everlasting. As all time, with everything that exists therein, is present with him at once, so he sees at once, whatever was, is, or will be, to the end of time. But observe: We must not think they are because he knows them. No; he knows them because they are." ${ }^{42}$

${ }^{40}$ Wesley, On Eternity, 190.

${ }^{41}$ Wesley is demonstrating the lack of understanding that humanity can have concerning God's omnipresence and his eternity. "A second essential attribute of God is eternity. He existed before all time. Perhaps we might more properly say, He does exist from everlasting to everlasting. But what is eternity? A celebrated author says, that the Divine eternity is vitce interminabilis tota simul et perfecta possessio: "The at once entire and perfect possession of never-ending life." But how much wiser are we for this definition? We know just as much of it as we did before. "The at once entire and perfect possession!" Who can conceive what this means?" Wesley, Imperfection of Human knowledge, 339.

${ }^{42}$ Wesley, Predestination, 226-227.

Oden describes Wesley's view of the eternal now as an expression of Platonic timelessness: "What we call 'now' keeps on vanishing, eluding our grasp, changing its face. Yet the present is the only position from which anyone can ever know or see the world, through the tiny keyhole of this constantly disappearing moment we can 'now.' This fleeting present lies 'between two eternities.' The moment we say 'now,' we have already lost the now in which we just said 'now.' We have this little splinter of ongoing time, which itself is a continuing refraction of the eternal." In his footnote Oden then connects the eternal now concept in Wesley's theology specifically with a Platonic ideas: "The Platonic idea that time is the unfolding expression of eternity is taken captive by Christ in the incarnation. It is a powerful idea, in 
This understanding of eternity is the classical theological understanding based on Greek philosophy. ${ }^{43}$

Wesley's understanding of God inhabiting eternity is tied together with his inhabiting all of space. ${ }^{44}$ God is truly omnipresent and this distinguishes God from his creation. While an individual human being has a spirit, which has God as its source and goal, God is nothing but spirit. ${ }^{45}$ This spiritual ontology of God is the reality by which he fills "all heaven and earth," a phrase which Wesley interprets as universal. ${ }^{46}$ Wesley explains God's omnipresence as a complete filling of all space, there is no empty space because God is filling it all. ${ }^{47}$

Wesley's view, that what we are experiencing right now is precisely eternity entering time, as seen by biblical revelation in the nativity of the Son." Thomas C. Oden, John Wesley's Teachings: God and Providence, 3 vols., vol. 1 (Grand Rapids, MI: Zondervan, 2012), 37-38.

${ }^{43}$ Cooper, Panentheism, 14-15.

${ }^{44}$ Wesley, Unity of Divine Being, 265-267.

45 "This God is a Spirit; not having such a body, such parts or passions, as men have. It was the opinion both of the ancient Jews and the ancient Christians, that He alone is a pure Spirit, totally separate from all matter; whereas they supposed all other spirits, even the highest angels, even cherubim and seraphim, to dwell in material vehicles, though of an exceeding light and subtle substance. At that point of duration which the infinite wisdom of God saw to be most proper, for reasons which lie hid in the abyss of his own understanding, not to be fathomed by any finite mind, God 'called into being all that is;' created the heavens and the earth, together with all that they contain. 'All things were created by him, and without him was not anything made that was made.' He created man, in particular, after his own image, to be 'a picture of his own eternity.' When he had raised man from the dust of the earth, he breathed into him an immortal spirit. Hence he is peculiarly called. 'The Father of our spirits;' yea, 'The Father of the spirits of all flesh." Wesley, Unity of Divine Being, 266-267.

${ }^{46}$ Wesley, Omnipresence, 242.

47 "And where no creature is, still God is there. The presence or absence of any or all creatures makes no difference with regard to him. He is equally in all, or without all. Many have been the disputes among philosophers, whether there be any such thing as empty space in the universe; and it is now generally supposed that all space is full. Perhaps it cannot be proved that all space is filled with matter. But the Heathen himself will bear us witness, Jovis omnia plena: 'All things are full of God.' Yea, and whatever space exists beyond the bounds of creation, (for creation must have bounds, seeing nothing is boundless, nothing can be, but the great Creator,) even that space cannot exclude Him who fills the heaven and the earth." Wesley, Omnipresence, 240-242. 
Wesley understands God's omnipresence as related with his eternity, omnipotence, and omniscience. ${ }^{48} \mathrm{He}$ asserts that no being can act in a place in which that being is not. God acts everywhere and in every time, therefore God must be present in all times and in all space. Wesley then reasons that if God is everywhere at all times, he also knows all things and is therefore omniscient. God as spirit is unlimited by time, space, power, and knowledge. ${ }^{49}$

For some forms of classical theism, the omnipresence of God in both time and space would appear to be in contradiction with the idea that God is timeless and unaffected by what is happening within time and space. It is possible that Wesley explains this contradiction by suggesting that time is a piece of eternity, therefore, God is present in time only while time lasts or perhaps God is present in eternity, which happens to include time. Once again, Wesley describes God as a being who is present in all times as an eternal now. His knowledge of the future includes the possible choices of freewill agents and is known because he holds that timeless status beyond the sequence of temporal events. ${ }^{50}$ Either way, with God present in all of space and time, Wesley, like all

48 " And he is omnipotent, as well as omnipresent; there can be no more bounds to his power, than to his presence. He 'hath a mighty arm; strong is his hand, and high is his right hand.' He doeth whatsoever pleaseth him, in the heavens, the earth, the sea, and in all deep places. With men we know many things are impossible, but not with God: With him 'all things are possible.' Whensoever he willeth, to do is present with him. The omniscience of God is a clear and necessary consequence of his omnipresence. If he is present in every part of the universe, he cannot but know whatever is, or is done there; according to the word of St. James, 'Known unto God are all his works,' and the works of every creature, 'from the beginning' of the world; or rather, as the phrase literally implies, 'from eternity."' Wesley, Unity of Divine Being, 266.

${ }^{49}$ Wesley, Omnipresence, 240.

${ }^{50}$ Wesley, Predestination, 226-227. Oden, Wesley's Teachings, 38. 
theologians, is struggling with the balance of the immanence and the transcendence of

God. ${ }^{51}$

\section{Distinct from Creation}

While God's immanence is clear from the above discussion, Wesley also holds to

God's transcendence and makes some careful distinctions between the creator and his

creation. All of creation is sustained by God and is given life from God, but Wesley is

careful to distinguish this providential presence from some sort of presence within

humanity which is beyond providence and establishes the likeness of God. ${ }^{52}$ Even in

Wesley's moment of emphasizing God's omnipresence, for the purpose of ethical living,

he uses the language of God being "about," "with," or "around" the believer, rather than

${ }^{51}$ Oden, Wesley's Teachings, 38.

52 In the classic quote from Wesley's third discourse on the sermon of the mount, he uses language that hints towards a panentheistic view of the God-World relationship. When compared with the following quote however it can be seen that Wesley did not believe in the same level of divine presence for general creation as for the indwelling presence of the just soul. "But the great lesson which our blessed Lord inculcates here, and which he illustrates by this example, is, that God is in all things, and that we are to see the Creator in the glass of every creature; that we should use and look upon nothing as separate from God, which indeed is a kind of practical Atheism; but, with a true magnificence of thought, survey heaven and earth, and all that is therein, as contained by God in the hollow of his hand, who by his intimate presence holds them all in being, who pervades and actuates the whole created frame, and is, in a true sense, the soul of the universe. John Wesley, The Works of John Wesley, Volume 5, Third Edition (London: Wesleyan Methodist Book Room, 1872), 283. Compare this to the following quote where Wesley makes the distinction: "The general character, therefore, of man's present state is death, -- a death from God, whereby we no longer enjoy any intercourse with him, or happiness in him; we no longer shine with his glory, or act with his powers. It is true, while we have a being, 'in him we must live, and move, and have our being;' but this we do now, not in a filial way, but only in a servile one, as all, even the meanest creatures, exist in him. It is one thing to receive from God an ability to walk and speak, eat and digest, -- to be supported by his hand as a part of this earthly creation, and upon the same terms with it, for farther trial or vengeance; and another, to receive from him a life which is his own likeness, -- to have within us something which is not of this creation, and which is nourished by his own immediate word and power." Wesley, Holy Spirit, 511. Wesley clarifies his understanding of the God-World relationship. Even the meanest creatures exist in God, but this is in a providential sense not an intermingling ontological being, as we can see in the following sentence where he clarifies that this is to "receive from God an ability to walk and speak, eat and digest...to be supported by his hand as a part of this early creation." God provides life and the power by which we live, this does not equal is being within us or our being with in his being, but rather his sustenance of our ability to live. For further discussion of a Wesleyan way of exploring the God-World relationship Cf. Michael E. Lodahl, God of Nature and of Grace: Reading the World in a Wesleyan Way (Nashville: Kingswood, 2004). 
some sort of an all-inclusive panentheistic understanding of God's omnipresence. ${ }^{53}$ God is present in every empty space and therefore surrounds his creation, but for Wesley he is still essentially distinct from his creation.

Wesley also suggests a dualistic cosmology of that which is seen and that which is unseen. Wesley wrote that these unseen things are all the more "eternal, solid, real, and unchangeable." 54 So not only is God distinct from creation, there is also a dual reality in Wesley's thinking. Once again, the apparent logical contradiction of a timeless God present in time and space demonstrated within classical theology can be seen in Wesley's hybrid understanding concerning the timeless nature of God who is also omnipresent in time and space. He tries to answer this with the providential sense of God's presence (as described above), but even an ongoing providential act of sustenance within time and space is a contradiction to a dualistic cosmology. God cannot reside in the world of ideas and penetrate the line into corporeal reality at the same time.

\section{God as Trinity}

Wesley's view of the importance of the doctrine of the Trinity cannot be overestimated. Wesley considered the Trinitarian doctrine to be fundamental for Christianity and at the very heart of Christianity. ${ }^{55}$ While Wesley, claims to not give an

${ }^{53}$ Wesley, Omnipresence, 242-243. Kenneth J. Collins corroborates the position that Wesley holds together the immanence and transcendence of God. "Wesley aptly holds together both the immanence and the transcendence of God, never one affirmation without the other. That is, to stress immanence to the neglect of transcendence would result in pantheism; to stress transcendence to the neglect of immanence would result in separation in which God would be and would remain unknown." Collins, Theology of Wesley, 23-24.

54 Wesley, On Eternity, 196.

55 "Hence, we cannot but infer, that there are ten thousand mistakes which may consist with real religion; with regard to which every candid, considerate man will think and let think. But there are some truths more important than others. It seems there are some which are of deep importance. I do not term them fundamental truths; because that is an ambiguous word: And hence there have been so many warm 
explanation of the how three can be one, he strongly defends that it is true, insisting that what cannot be understood should not preclude the believer from accepting the truth of what is revealed. ${ }^{56}$ His emphasis on the Trinity is found both in the economic roles that each person plays in the plan of salvation, as well as the differentiation of the persons in the Trinity, thus rejecting a Unitarian view based on any one of the members of the

disputes about the number of fundamentals. But surely there are some which it nearly concerns us to know, as having a close connexion with vital religion. And doubtless we may rank among these that contained in the words above cited: 'There are three that bear record in heaven, the Father, the Word, and the Holy Ghost: And these three are one." Wesley, Trinity, 200. Multiple Wesleyan scholars highlight the Trinitarian aspect of Wesley's theology. Maddox is one, "Since Wesley neglected many of the finer distinctions of Trinitarian doctrine and rarely engaged in protracted debates over the topic, one might think that he would join Schleiermacher in confining it to an appendix of Christian doctrine. Quite the contrary! He actually argued that the truth of the Trinity "enters into the very heart of Christianity; it lies at the root of all vital religion." Maddox, Responsible Grace, 139. Loyer is another, "God is Father, Son, and Holy Spirit. While Wesley rarely engaged in prolonged debates over this doctrine (although he clearly distanced himself from the anti-trinitarianism of his day, as shown below), it was nevertheless essential to his understanding of the faith. As he writes in his sermon On the Trinity, the truth of the Trinity 'enters into the very heart of Christianity; it lies at the root of all vital religion.'" Loyer, God's Love through the Spirit, 31. In the first chapter of his Dissertation on the Holy Spirit within Wesley, Sarkey also emphasizes the Trinitarian nature of Wesley's theology. Lycurgus Monroe Starkey, Jr., "The Work of the Holy Spirit in the Theology of John Wesley" (Dissertation, Columbia University, 1953).

56 "To apply this to the case before us: 'There are three that bear record in heaven: And these three are one.' I believe this fact also, (if I may use the expression,) that God is Three and One. But the manner how I do not comprehend; and I do not believe it now in this, in the manner, lies the mystery; and so it may; I have no concern with it: It is no object of my faith: I believe just so much as God has revealed, and no more." Wesley, Trinity, 204. Wesley even defends the Trinity on the grounds of textual criticism by claiming the originality of 1 John 5:7. Wesley gave three points to his argument for why 1 John 5:7 should be considered as part of the canonical manuscripts, the political nature of it's removal, and the witness of the early church fathers, "(1.) That though it is wanting in many copies, yet it is found in more; and those copies of the greatest authority:- (2.) That it is cited by a whole gain of ancient writers, from the time of St. John to that of Constantine. This argument is conclusive: For they could not have cited it, had it not then been in the sacred canon:- (3.) That we can easily account for its being, after that time, wanting in many copies, when we remember that Constantine's successor was a zealous Arian, who used every means to promote his bad cause, to spread Arianism throughout the empire; in particular the erasing this text out of as many copies as fell into his hands. And he so far prevailed, that the age in which he lived is commonly styled, Seculum Arianum, - 'the Arian age;' there being then only one eminent man who opposed him at the peril of his life. So that it was a proverb, Athanasius contra mundum: "Athanasius against the world." Wesley, Trinity, 201. 
Godhead. ${ }^{57}$ This is demonstrated in his Christology and Pneumatology, which will be explored next. ${ }^{58}$

\section{Wesley's Christology}

Wesley emphasizes both the divinity and the humanity of Christ. He uses the traditional formulas to express Christ's divinity, "'God of God, Light of Light, very God of very God,' in glory equal with the Father, in majesty co-eternal..." ${ }^{, 59}$ For Wesley Jesus is equal with the father in his union with God in character and as a divine person of the Godhead, but he was also inferior because of his humanity. ${ }^{60}$ Jesus also has human righteousness within his human nature, this is an internal righteousness based in the stamp of the image of God upon every part of his soul and this makes him the perfect

${ }^{57}$ Maddox describes the deficiencies of Unitarian emphasis on any one of the members of the God head, to the detriment of the other two. Maddox, Responsible Grace, 140. Maddox once again points to the influence which Eastern Orthodoxy had on Wesley in this matter, comparing Wesley's emphasis on the personhood of the members of the Trinity with the Eastern doctrine of perichoresis: "I hasten to add, however, that distinctness does not imply separation or opposition! To protect against such connotations of distinguishing the 'Persons of the Trinity, Eastern Orthodox theology eventually developed a doctrine of the thorough co-inherence (perichoresis) of Father, Son, and Spirit. Similarly, Wesley would affirm that the three Divine 'Persons' are 'one in essence, in knowledge, in will, and in their testimony.' The reference to unity of essence here may seem to override any distinction between the 'Persons.' However, Wesley was likely referring to equal possession of full Divine power, not undifferentiated identity of being.' As such, one might say that Wesley adopted the notion of perichoresis, even though he never explicitly referred to it (and likely did not know it in any exact terms)." Maddox, Responsible Grace, 138-139.

${ }^{58}$ Christology is an important part of this paper in the comparison between Wesley and John B. Cobb Jr. Showing that Wesley clearly identifies Jesus Christ as divine and also divine is a distinction from Cobb who considers the man Jesus to be the Christ only in degree rather than in kind when compared with other persons of the human race. This will be more fully developed in Chapter 3 of this dissertation.

Pneumatology is also essential in the discussion of divine-human indwelling, as the Holy Spirit is generally regarded as the means of the divine indwelling of humans within Christianity in general and for Wesley in particular.

${ }^{59}$ Wesley, What is Man?, 171-172.

60 "His divine righteousness belongs to his divine nature, as he is $\mathrm{O} \omega \mathrm{v}$, He that existeth; 'over all, God blessed forever;' the Supreme; the Eternal; 'equal with the Father, as touching his Godhead, though inferior to the Father as touching his manhood.' Now this is his eternal, essential, immutable holiness; his infinite justice, mercy, and truth; in all which, He and the Father are One." Wesley, Lord our

Righteousness, 236. 
mediator between God and man. ${ }^{61}$ Christ is clearly part of the Trinity and yet distinct as a

person, emphasized by his role as the human mediator of the Trinity.

\section{Wesley's Pneumatology}

For Wesley, the first reality concerning the Holy Spirit in relation to the Trinity that must be considered is that God is Spirit. ${ }^{62}$ God breathes his spirit onto all of creation as the principle of motion giving the providence and sustenance of life to all of creation. ${ }^{63}$ There is, however, also a particular person of the Spirit, who is a member of the Godhead. This Holy Spirit is given to bring a new life to those who have been lost in sin. The giving of this Holy Spirit is purchased for the sanctification of believers through Christ's incarnation, preaching, and death. ${ }^{64}$

For Wesley, the Holy Spirit's role as a member of the Godhead is seen as the

61 "The human righteousness of Christ belongs to him in his human nature; as he is the 'Mediator between God and man, the Man Christ Jesus.' This is either internal or external. His internal righteousness is the image of God, stamped on every power and faculty of his soul. It is a copy of his divine righteousness, so far as it can be imparted to a human spirit. It is a transcript of the divine purity, the divine justice, mercy, and truth. It includes love, reverence, resignation to his Father; humility, meekness, gentleness; love to lost mankind, and every other holy and heavenly temper; and all these in the highest degree, without any defect, or mixture of unholiness." Wesley, Lord our Righteousness, 236. The language of the image of God being stamped on the soul of Christ is a hint to how the divine-human indwelling might work for Wesley. This language is similar to the language which is found in the church fathers regarding the spirit as the formal cause of righteousness in the believer.

${ }^{62}$ Wesley, Means of Grace, 186. Wesley ties the omnipresence of God to his nature as Spirit, a spirit which pervades and fills the whole universe. Wesley, New Creation, 289-290.

63 "He first created the four elements, out of which the whole universe was composed; earth, water, air, and fire, all mingled together in one common mass. The grossest parts of this, the earth and water, were utterly without form; till God infused a principle of motion, commanding the air to move "upon the face of the waters." Wesley, Approbation, 207.

64 'But the ministration of the New Testament was that of a 'Spirit which giveth life;' -- a Spirit, not only promised, but actually conferred; which should both enable Christians now to live unto God, and fulfil precepts even more spiritual than the former; and restore them hereafter to perfect life, after the ruins of sin and death. The incarnation, preaching, and death of Jesus Christ were designed to represent, proclaim, and purchase for us this gift of the Spirit; and therefore says the Apostle, 'The Lord is that Spirit,' or the Spirit." Wesley, Holy Spirit, 508. 
primary agent of sanctification. In fact for Wesley there is no power to save but by the

Holy Spirit, for there is no other means by which grace is conveyed. ${ }^{65}$ Humanity is not sufficient in itself to stop sinning, the power of the Spirit is required. ${ }^{66}$ It is by the Spirit that the image of God is restored within fallen humanity. ${ }^{67}$ It is the spirit who leads humanity to the understanding of Scripture and thus to salvation. ${ }^{68}$ Wesley did not believe that the Spirit was given to the Methodists in some sort of special measure but to all Christians in general. He, therefore, stayed at a distance from the idea of the Spirit giving revelation or visions. He preferred to speak of the Spirit functioning as a guide to truth, a comforter who purifies and supports the will, and the one who hears prayers. ${ }^{69}$ In explaining the texts regarding the grieving of the Holy Spirit, Wesley highlights the intimate role of the Spirit with the believer. God as Trinity is grieved at the sin of the believers and this grief is particular to the Holy Spirit, because he is the

${ }^{65}$ Wesley, Means of Grace, 201.

${ }^{66}$ Wesley, Circumcision of the Heart, 203-204.

${ }^{67}$ Wesley, Fall of Man, 223. Wesley, Grieving the HS, 485.

68 "While there were many positive aspects of the holy living tradition (despite its imbalance), Wesley's immersion in its writers almost seemed to shield him from the aforementioned proper understanding of justification by grace through faith alone. So where did Wesley go from there, and what can we learn from his frenetic search for the perceptible evidence of his own assurance of salvation? At the very foundation of any experience of genuine Christian assurance lies an important aspect of calling and convicting grace ('prevenient grace'). And this special facet of grace is the 'illuminating' work of the Holy Spirit that leads and guides believers into a solid understanding of Bible truth, especially those truths regarding the basics of salvation. Therefore, the Spirit of God not only convinces believers that the Bible is a truly inspired source of truth but also leads to a personal saving knowledge of the great principles of salvation." Woodrow W. Whidden, The Judgment and Assurance: The Dynamics of Personal Salvation (Hagerstown, MD: Review and Herald Pub. Association, 2012), 98.

${ }^{69}$ Collins demonstrates this in Wesley's reply to Warburton who described the Methodists as fanatics when it came to the Holy Spirit. Pointing to Wesley's reply, Collins says: "Wesley pointed out that he and the Methodists did not 'pretend to any extraordinary measure of the Spirit,' but only to what could be claimed by every Christian minister. Putting aside dreams, visions, and revelations as being of a doubtful or disputable nature, Wesley instead focused on the operations of the Spirit as the 'Guide of truth' who enlightens the understanding as 'the comforter who purifies and supports the will,' and as the One who now 'hears and answers prayer..."Collins, Theology of Wesley, 180. 
member of the Godhead who is the closest to the believers and most directly and intimately related in the salvation process of the believer. ${ }^{70}$ Wesley is careful to hold to the classical understanding of the ontology of God by defining the grief of the Holy Spirit being related to the will rather than passions. God cannot have passions, therefore the grieving of the Spirit is the believer's turning against the will of the Spirit. ${ }^{71}$ The Spirit having a will that can be opposed, offers evidence of the personhood of the Holy Spirit, which is significant for Wesley. The personhood of the Spirit is also demonstrated in Wesley's definition of God's grace as love. This love is given to humanity by the Holy Spirit and love by nature must be shared between two persons, thus making the Spirit a person. $^{72}$

${ }^{70}$ Wesley highlights three reasons why the Holy Spirit is grieved and his use of personal pronouns in this statement help to emphasize Wesley's acceptance of the personhood of the Holy Spirit, "And the reasons for which it is peculiarly applied to him are: First, because he is more immediately present with us; Second, because our sins are so many contempts of this highest expression of his love, and disappoint the Holy Spirit in his last remedy; and, Third, because, by this ungrateful dealing, we provoke him to withdraw from us." It is also significant for the later comparison with Cobb that the Holy Spirit can withdraw from us; this supports a classical theism rather than a panentheistic understanding of God's ontology. Wesley, Grieving the HS, 485-486.

71 "I am, First, to inquire, in what sense the Spirit of God may be said to be grieved with the sins of men. There is not anything of what we properly call passion in God. But there is something of an infinitely higher kind: Some motions of his will, which are more strong and vigorous than can be conceived by men; and although they have not the nature of human passions, yet will answer the ends of them. By grief, therefore, we are to understand, a disposition in God's will, flowing at once from his boundless love to the persons of men, and his infinite abhorrence of their sins. And in this restrained sense it is here applied to the Spirit of God in the words of the Apostle." Wesley, Grieving the HS, 486.

72 "Wesley's equation of the Holy Spirit with God's power should not be construed as suggesting that the Holy Spirit was only an attribute of God, or even a created agent of God. He was quite clear that the Holy Spirit was fully divine, 'equal with the Father and the Son. If he seldom tried to prove this, it was because he took it for granted. He was equally clear that the Holy Spirit should be seen as fully personal, not merely a force or energy in our lives. This point was central to his understanding of grace. It was argued in Chapter 3 that Wesley's conception of God's restoring grace resonated with the Eastern notion of uncreated grace. Grace, for him, was not simply a Divinely-originated product bestowed upon humanity, it was the activity of God's very Self in human life. As Daniel Luby has so aptly defined it, 'Grace for Wesley [was] the pardoning, transforming love of God, present to us in the indwelling Person of the Holy Spirit.' The centrality of love to the Spirit s work will be developed later. At this point I want simply to note that if our experience of grace is epitomized in love, then the Holy Spirit must be fully personal, because love is something that exists in its sense only between persons." Maddox, Responsible Grace, 120. Starkey also emphasizes the personal nature of the Holy Spirit in Wesley's writing. Starkey, "Word of the Holy Spirit", 


\section{Summary}

For Wesley, God's ontology can be explained in a multifaceted way. First, Wesley held to a hybrid of tension between the timelessness of God as eternal now and God's omnipresence in all of space. Second, while God is omnipresent within all of space, he is also distinct from his creation. He is generally present with all of creation through providence and specifically present with humanity in some way which makes them in his likeness. Third, God is a Trinity of three co-eternal, divine persons. Each person plays a significant role in the economy of salvation. Jesus is fully divine and coeternal with the Father and yet is human as well. The Holy Spirit has a distinct personhood from God's general spirit-based ontology. The Spirit's personhood can be seen in both the opposition to the Spirit's will, grieving the Spirit, and as the source of divine love given to humanity.

Many elements of Wesley's ontology of God are in accord with classical theism. His emphasis on the immanence of God may show some of the Eastern influences on his theology, but he continues to hold it in tension with the transcendence of God with his Western logic. This transcendent ontology of God must also be related to Wesley's dualistic cosmology, including an unseen realm in which the more real things exist. As demonstrated by Collins, Wesley stays away from a pantheistic and panentheistic understanding of the ontology of God. ${ }^{73}$ The implications of Wesley's classical theism for his view of divine-human indwelling will be explored in a later section of this chapter.

$4-7$.

${ }^{73}$ Collins, Theology of Wesley, 23-24. 


\section{The Ontology of Humanity}

In order to understand Wesley's model of the ontological nature of divine-human indwelling, it is also necessary to grasp his understanding of the ontology of humanity. In this section of this research it will be demonstrated that Wesley teaches a dualistic union of the human body with an immortal soul and that humanity was made in the image and likeness of God. For Wesley, humanity's fall from the divine image has caused the necessity of a temporary separation of the body and soul at death, but through the process of salvation the image and likeness of God can be restored.

\section{Wesley's Dualistic Ontology of Humanity}

Wesley is very strong in his assertions regarding the dualistic nature of humanity. It cannot be mistaken that he considers humanity to be made up of two separable parts, the body and the soul. ${ }^{74}$ For Wesley, the body is a machine made up of the four basic elements; water, earth, air, and an ethereal fire which brings the warmth of life. ${ }^{75}$ This body made of these basic elements consists of its various parts and sinews, but even the ethereal fire is not enough to animate the body. ${ }^{76}$ Something of a different nature than the body is needed to give governance to this earthly vessel. For Wesley that something else

${ }^{74}$ What follows is a collection of the references regarding Wesley's demonstration of his belief in the dualistic nature of humanity into body and soul. Wesley, Witness of Our Own Spirit, 137-138; Wesley, On Eternity, 190-191; Wesley, Trinity, 203-204; Wesley, Hell, 383-386, 390; Wesley, Perfection, 412-413; Wesley, Temptation, 477; Wesley, Sermon CIII, 171, 174; Wesley, Sermon CIX, 225-227; Wesley, Heavenly Treasures, 346-347.

${ }^{75}$ Wesley, Sermon CIX, 225.

${ }^{76}$ Wesley, Sermon CIX, 225. 
is the soul. ${ }^{77}$ The soul is what governs every action of the body. ${ }^{78}$ This governing entity of the body (the soul indwelt by the Holy Spirit) is also what Wesley considers to be the image of God within each individual. ${ }^{79}$

Wesley is not sure where the soul may be located within the body. He rules out appendages, blood, bones, and the like and eventually settles on the brain. He is not sure whether it resides within the brain in general or perhaps more specifically the pineal gland. ${ }^{80}$ The mystery of the union of body and soul, for Wesley, is akin to the mystery of the threeness and oneness of the Trinity ${ }^{81}$ But the union is clearly there in a reciprocal fashion. The soul gives the body its "inward principle of motion." ${ }^{\text {" }}$ The soul motivates the body by will, as well as a self-determination. Wesley believes that there are involuntary movements which the soul gives to the body, such as vital functions like the pumping of the heart or breathing, but everything else is controlled by the will of the soul ${ }^{83}$ The will is combined with self-determination so that a person can decide to change the actions the body is doing at any moment of time. This ability to self-govern is a key to what it means to exist as a human being. ${ }^{84}$

\footnotetext{
${ }^{77}$ Wesley, Sermon CIX, 226.

${ }^{78}$ Wesley, Sermon CIX, 227.

${ }^{79}$ Wesley, Sermon CIII, 171. Wesley also suggests that the image of God is the indwelling of the Holy Spirit within the soul and that this image is lost at the fall of humanity. This will be further explored in the section of this chapter on the image of God.

${ }^{80}$ Wesley, Sermon CIX, 226.

${ }^{81}$ Wesley, Sermon CIX, 227.

${ }^{82}$ Wesley, Sermon CIX, 227.

${ }^{83}$ Wesley, Sermon CIX, 227-228.

${ }^{84}$ Wesley speaks of the will being essential to human nature: "A will every man must inevitably have, as long as he has an understanding. This is an essential part of human nature, indeed of the nature of
} 
The soul, however, is also affected by the body. Wesley mentions multiple times that the fallen nature of the body hampers the soul from its true capacity to function. $\mathrm{He}$ likened the relationship to a musician playing a poor instrument. The artist can only do so much with an inferior instrument. ${ }^{85}$ For Wesley it is the same for the soul trying to govern the body. The sickness, deterioration, and pain of the body cannot help but keep the soul repressed. ${ }^{86}$ This reciprocal relationship between body and soul, Wesley suggested, almost led him to believe that who a person is, is related to both the body and the soul. ${ }^{87}$ This however is not completely true, for the self of the person will continue to exist beyond the body. The soul is part of the unseen world, the world which is more real and unchanging and therefore will outlive the body. ${ }^{88}$

According to Wesley, death is the separation of the body from the soul. He is not sure at what time this separation actually occurs. If a person stops breathing they can be revived, as they can if their heart stops or even if their body goes completely cold and stiff. The moment of separation is a mystery known only to God. ${ }^{89}$ The body is a significant enough part of the person that Wesley believes there will be a time when the two will be reunited after the resurrection. ${ }^{90}$ In order to better understand Wesley's views

every intelligent being. Our blessed Lord himself had a will as a man; otherwise he had not been a man." Wesley, Repentance of Believers, 158.

${ }^{85}$ Wesley, Heavenly Treasures, 346-347.

${ }^{86}$ Wesley, Perfection, 412-413.

${ }^{87}$ Wesley, Sermon CIX, 228.

${ }^{88}$ Wesley, Sermon CIII, 171.

${ }^{89}$ Wesley, Sermon CIX, 229.

${ }^{90}$ Wesley, Sermon CIX, 228. 
on this, the next section will go more in depth into Wesley's view of the immortal soul.

\section{Wesley's View of the Immortal Soul}

Wesley's understanding of the immortality of the soul is complex, and yet clear, once everything is taken into consideration. ${ }^{91}$ Wesley asserts that that the soul of humanity is already dead, at the moment that Adam turned away from God there was a death of the soul that took place. ${ }^{92}$ Wesley seems to suggest that the soul can be destroyed, following Jesus' references in the gospels to fear the one who can destroy the soul. ${ }^{93}$ There are several passages that might cause one to wonder if Wesley does believe in some sort of soul death. But Wesley then goes on to clarify what soul death is - the separation of the soul from God as the soul is separated from the body at death. ${ }^{94}$

The time of death is the natural time when the body separates from the soul. For Wesley the separation of the soul from God happens at the moment of sin. The human spirit, for Wesley, is dead in its sins without knowing it. ${ }^{95}$ This is the condition of the fallen human ontology, separated from God in the death of the soul. Wesley calls for every soul to awake from this death and accept by faith the love and knowledge of God,

${ }^{91}$ Collins mentions the apparent contradiction between Wesley's view of the immortality of the soul, combined with the death of the soul within a single sentence in his sermon Image of God. But Collins then sees the clarification to mean the separation from God as the death of the soul, rather than it ceasing to exist. Collins, Theology of Wesley, 60-61.

${ }^{92}$ Wesley, Justification 54-55.

${ }^{93}$ Wesley, Way of the Kingdom, 83-84.

94 "Man did disobey God. He 'ate of the tree, of which God commanded him, saying, Thou shalt not eat of it.' And in that day he was condemned by the righteous judgment of God. Then also the sentence whereof he was warned before, began to take place upon him. For the moment he tasted that fruit, he died. His soul died, was separated from God; separate from whom the soul has no more life than the body has when separate from the soul." Wesley, Justification 54-55.

${ }^{95}$ Wesley, Awake, 25-26. 
which is the beginning of eternal life. ${ }^{96}$ The soul can be reunited with God through the knowledge and love of God; and the restoration process of the image of God in that person will begin immediately at the moment of justification and throughout the process of sanctification, until it is entirely restored in entire sanctification. ${ }^{97}$

Wesley brought even further clarification to the immortality of the soul and its state of union or separation from God, when he considers the eschatological fate of the souls which have accepted or rejected God. For those who accept God and are awakened to life and union with God, they are fully united with God once death has come to separate their soul from their bodies. ${ }^{98}$ God is both the source and the end of the righteous soul for Wesley. ${ }^{99}$ The soul not only returns to God but also returns to timeless existence, where a thousand, even a million years, pass as if in a moment, united with the bliss of God. ${ }^{100}$ The soul who does not choose God, however, is separated from God forever. This

96 You can see some of the confusion on the position of Wesley concerning whether there might be a condition to immortality in this passage; but you can also see the possibility of regaining immortal life though the love and knowledge of God. "The essential, unchangeable difference is this: The one supposes him to whom it is given to be already holy and happy, created in the image and enjoying the favour of God; and prescribes the condition whereon he may continue therein, in love and joy, life and immortality: The other supposes him to whom it is given to be now unholy and unhappy, fallen short of the glorious image of God, having the wrath of God abiding on him, and hastening, through sin, whereby his soul is dead, to bodily death, and death everlasting; and to man in this state it prescribes the condition whereon he may regain the pearl he has lost, may recover the favour and image of God, may retrieve the life of God in his soul, and be restored to the knowledge and the love of God, which is the beginning of life eternal." Wesley, Righteousness of Faith, 69-70.

${ }^{97}$ Wesley, Righteousness of Faith, 69.

${ }^{98}$ Wesley suggests that at this time of the union of the soul with God after death, God will truly be the all in all for that soul. Wesley, Repentance of Believers, 170.

${ }^{99}$ Wesley, Circumcision of the Heart, 208.

100 "Accordingly, a believer, in the scriptural sense, lives in eternity, and walks in eternity. His prospect is enlarged: His view is not any longer bounded by present things: No, nor by an earthly hemisphere; though it were, as Milton speaks, 'ten-fold the length of this terrene.' Faith places the unseen, the eternal world continually before his face. Consequently, he looks not at 'the things that are seen;''Wealth, honour, pleasure, or what else This short-enduring world can give;' these are not his aim, the object of his pursuit, his desire or happiness;- - but at 'the things that are not seen;' at the favour, the image, and the glory of God; as well knowing that 'the things which are seen are temporal, - - a vapour, a shadow, 
soul death is the second death, a complete separation from God which is spent in an eternity of torment. ${ }^{101}$ Wesley used these views of eternity in his sermons as motivation for choosing to trust in God. He urged people to consider eternity and whether they would rather be in bliss forever with God or in eternal torment as a worm that never dies in a fire that is unquenchable. ${ }^{102}$

Wesley clearly believed in the immortality of the soul and its being created for eternity from the beginning. ${ }^{103}$ Matter, for Wesley, also has a certain kind of immortality in that it will change forms and continue to exist. Matter will be broken down into its various atoms and continue to exist, unless God would choose by his power to annihilate matter. Wesley believed however that even when God melts the elements of the cosmos, matter will still exist, simply in a different form. ${ }^{104}$ So to a certain extent the material of the body lives on after death. The soul however does not seem to change form, but rather exists consciously, either united in the bliss of God or separated from God in eternal torment. ${ }^{105}$

a dream that vanishes away; whereas 'the things that are not seen are eternal;' real, solid, unchangeable." Wesley, On Eternity, 194,196.

$$
\begin{aligned}
& { }^{101} \text { Wesley, Righteousness of Faith, } 69 . \\
& { }^{102} \text { Wesley, On Eternity, 195-196. }
\end{aligned}
$$

103 "But leaving one of these unbounded seas to the Father of eternity, to whom alone duration without beginning belongs, let us turn our thoughts on duration without end. This is not an incommunicable attribute of the great Creator; but he has been graciously pleased to make innumerable multitudes of his creatures partakers of it. He has imparted this not only to angels, and archangels, and all the companies of heaven, who are not intended to die, but to glorify him, and live in his presence for ever; but also to the inhabitants of the earth, who dwell in houses of clay. Their bodies, indeed, are 'crushed before the moth;' but their souls will never die. God made them, as an ancient writer speaks, to be 'pictures of his own eternity.' Indeed all spirits, we have reason to believe, are clothed with immortality; having no inward principle of corruption, and being liable to no external violence." Wesley, On Eternity, 190-191.

$$
\begin{aligned}
& { }^{104} \text { Wesley, On Eternity, 191-192. } \\
& { }^{105} \text { Wesley, On Eternity, 194-196. }
\end{aligned}
$$


Wesley's understanding of the immortal soul plays into the question of the ontological nature of divine-human indwelling in significant ways. The soul was originally created as the image of God, united with God somehow. At the moment of sin, the soul was separated from God as the soul is separated from the body at death. Ontologically then, there was as much of a union between God and the soul as the body with the soul. This is a union which can be restored, but it also may not be. Once again we can see Wesley's view matching with that some significant streams of classical theism. For Wesley, the image of God is clearly tied into this process of union with God. This will be further explored in the next section.

\section{Wesley's Conception of the Image of God}

Humanity being made in the image of God is very significant for Wesley's understanding of human ontology. There are several ways in which Wesley believes the image of God can be seen in humans, and they are the very aspects that make humans different from the animals. First, God is immortal spirit and he placed an immortal spirit within the bodies of human beings. ${ }^{106}$ Animals and the other parts of creation do not have this immortal spirit within them. Second, Wesley stresses the moral image of God, which was given to humankind. Adam was created with the ability to choose right from wrong. ${ }^{107}$ As has been previously seen in this chapter, Wesley believes the will is an essential part of the soul and it is also essential for humanity to be made in the image of

\footnotetext{
106 "Because man was created in the image of God: Because he is not mere matter, a clod of earth, a lump of clay, without sense or understanding; but a spirit like his Creator, a being endued not only with sense and understanding, but also with a will exerting itself in various affections." Wesley, Fall of Man, 215.

${ }^{107}$ Wesley, Fall of Man, 222-223.
} 
God. If free will was not a part of the ontology of humanity, then humans would be no different than the brute beasts around them. ${ }^{108}$ God, however, placed this will within the human spirit and this makes it possible for humans to reflect the image of God politically as well as morally. Third, Wesley understood the image of God to be evident in humanity's sovereignty over the rest of creation. ${ }^{109}$

Wesley's fourth and final way to define the image of God, and the most important for this dissertation, is the indwelling of the Holy Spirit. "Our first parents did enjoy the presence of the Holy Spirit; for they were created in the image and likeness of God, which was no other than his Spirit." ${ }^{, 10}$ Wesley asserted that the greater Spirit, the Holy Spirit, was originally united with the lesser spirit, the human spirit, when humanity was created. ${ }^{111}$ This union with the Holy Spirit is what it means to be made in the image of God. This union was lost at the moment of sin. ${ }^{112}$ The Holy Spirit removed himself - his

108 "But what all the wisdom of man was unable to do, was in due time done by the wisdom of God. When it pleased God to give an account of the origin of things, and of man in particular, all the darkness vanished away, and the clear light shone. 'God said, Let us make man in our own image.' It was done. In the image of God man was made. Hence we are enabled to give a clear, satisfactory account of the greatness, the excellency, the dignity of man. But 'man, being in honour,' did not continue therein; but rebelled against his sovereign Lord. Hereby he totally lost, not only the favour, but likewise the image, of God. And 'in Adam all died:' For fallen 'Adam begat a son in his own likeness.' And hence we are taught to give a clear, intelligible account of the littleness and baseness of man. He is sunk even below the beasts that perish. Human nature now is not only sensual, but devilish. There is in every man born into the world, (what is not in any part of the brute creation; no beast is fallen so low, a 'carnal mind, which is enmity,' direct enmity, 'against God."' Wesley, Heavenly Treasures, 344.

${ }^{109}$ Collins recognizes the political image of God and places the moral image as the priority for Wesley, primarily because it is the fall of the moral image which results in the fall of the political image. Collins, Theology of Wesley, 54-55, 62-63.

${ }^{110}$ Wesley, Holy Spirit, 509.

111 "In the beginning, the heavenly Word, -- being a Spirit that issued from the Father, and the Word of his power, -- made man an image of immortality, according to the likeness of the Father; but he who had been made in the image of God, afterwards became mortal, when the more powerful Spirit was separated from him.” Wesley, Holy Spirit, 512-513.

112 "Adam, in whom all mankind were then contained, freely preferred evil to good. He chose to do his own will, rather than the will of his Creator. He 'was not deceived,' but knowingly and deliberately rebelled against his Father and his King. In that moment he lost the moral image of God, and, in part, the 
presence from the soul of the fallen sinner. Therefore, humanity in a fallen state no longer bears the image of God. ${ }^{113}$

The fallen state affects all aspects of Wesley's understanding of the image of God. Humanity has become morally corrupt. Once Adam chose evil over good, his ability to choose good was greatly diminished, as was the ability of all humanity who followed him. ${ }^{114}$ The political image of God was lost when Adam sinned. Through a moral fall the difference between humans and brute beasts was removed. ${ }^{115}$ Humanity had once been the mediators between God and brute creation, but as they were no longer able to know and love God in a more significant way than the rest of brute creation they lost this political position. ${ }^{116}$ The human spirit, now pressed down by the mortal and sinful body, has desires for earthly things more than heavenly things. ${ }^{117}$ Thus, they were no longer different from the beasts who desire the same things, and could no longer be considered as rulers over them.

Wesley taught that this lost image of God can be restored. ${ }^{118}$ Restoration comes

natural: He commenced unholy, foolish, and unhappy. And 'in Adam all died:' He entitled all his posterity to error, guilt, sorrow, fear, pain, diseases, and death.” Wesley, Fall of Man, 222-223. Wesley, Holy Spirit, 509-510.

\footnotetext{
${ }^{113}$ Wesley, Heavenly Treasures, 344.

${ }^{114}$ Wesley, Heavenly Treasures, 344-345.

${ }^{115}$ Wesley, Holy Spirit, 510.

${ }^{116}$ Wesley, The General Deliverance, 245.

${ }^{117}$ Wesley, Fall of Man, 219.
}

118 "This, then, is the treasure which they have received; - a faith of the operation of God; a peace which sets them above the fear of death, and enables them in everything to be content; an hope full of immortality, whereby they already 'taste of the powers of the world to come;' the love of God shed abroad in their hearts, with love to every child of man, and a renewal in the whole image of God, in all righteousness and true holiness." Wesley, Heavenly Treasures, 345-346. 
first through the substitutionary propitiation of the death of Christ. It was necessary for Jesus Christ, as the second Adam, to bear the full image of God and make restitution for the fallen human race. ${ }^{119}$ Once the grace of the death of Jesus is accepted by the believer, the Holy Spirit begins the restoration process by the pouring of divine love into the believer. ${ }^{120}$ Since the image of God includes union with the Holy Spirit, it is apparent that the indwelling of the Spirit, re-established at the moment of justification, is the basis for restoring the image of God in fallen humanity. It was the original grace at creation which stamped the image of God upon the human soul, and now the image of God is renewed by the restorative grace purchased by the death of Christ. ${ }^{121}$ Just as Adam was the first birth of humanity, and brought the fallen nature of sin, Jesus was the new birth of humanity, restoring the image of God in humanity. ${ }^{122}$

The understanding of the image of God as part of human ontology builds the bridge that is needed to understand Wesley's interpretation of the ontological divinehuman indwelling in harmony with the elements of his theology that are in accord with

119 “'Believe in the Lord Jesus Christ, whom God hath given to be the propitiation for thy sins, and thou shalt be saved;' first, from the guilt of sin, having redemption through his blood; then from the power, which shall have no more dominion over thee; and then from the root of it, into the whole image of God. And being restored both to the favour and image of God, thou shalt know, love, and serve him to all eternity." Wesley, Sermon CIX, 227-230.

${ }^{120}$ Wesley, Heavenly Treasures, 345-346.

${ }^{121}$ Wesley, Salvation by Faith, 7-8.

122 "To remedy this, the Word became Man, that man by receiving the adoption might become a son of God once more; that the light of the Father might rest upon the flesh of our Lord, and come bright from thence unto us; and so man, being encompassed with the light of the Godhead, might be carried into immortality. When he was incarnate and became man, he recapitulated in himself all generations of mankind, making himself the centre of our salvation, that what we lost in Adam, even the image and likeness of God, we might receive in Christ Jesus. By the Holy Ghost coming upon Mary, and the power of the highest overshadowing her, the incarnation of Christ was wrought, and a new birth, whereby man should be born of God, was shown; that as by our first birth we did inherit death, so by this birth we might inherit life." Wesley, Holy Spirit, 512-513. 
classical theism. Humanity was created in union with the presence of God, through the indwelling of the Holy Spirit upon the soul, but when the fall happened that presence was removed. Since the image of God is "stamped on the soul," this suggests that the union with the Holy Spirit is the formal cause for the soul, which is the traditional view of classical theism. ${ }^{123}$

\section{Wesley's View of Spiritual Senses}

According to Wesley, with the new birth, the immortal soul is restored to spiritual life and the spiritual senses. Wesley believed that all of the knowledge of life is gained through the physical senses which bring understanding of the physical world and through the spiritual senses which bring understanding of the spiritual world. These senses were lost with the image of God, and are also restored when the image of God is restored. ${ }^{124}$

\section{Summary and Conclusion}

For Wesley, the ontology of humanity is a combination of the body, made from the basic elements of creation, along with an immortal soul, which gives animation, will, and self-determination to human beings. This immortal soul will outlast the body and at the time of death be separated from the body to spend eternal bliss united with God or eternal torment separated from God. It is the union of the Holy Spirit with the immortal soul which establishes humanity in the image of God. The image of God is a moral image - allowing humanity to choose its own course of action, and a political image possessing self-determination and a will that differentiates humanity from the beasts of

\footnotetext{
${ }^{123}$ For a further explanation of this position as part of classical theism, please see the historical background section of this dissertation found in Chapter 1.

${ }^{124}$ Loyer, God's Love through the Spirit, 36-37.
} 
creation, thus allowing humanity to rule over them. At the moment of sin the ontology of humanity changed from a mysterious union of body, soul, and the Holy Spirit in the image of God, to the degradation of humanity to the level of beasts separated from God, thus losing the divine image. For Wesley, it was only through the propitiation of Christ's life and death for humanity, as the second Adam, which allows for the image of God to be restored once again.

Wesley's ontology of humanity suggests several things that apply to the question of divine-human indwelling. Wesley holds to elements of classical theism in which God, through his spirit, was ontologically united with the souls of humanity at the beginning. This union seems to be one of formal causality, as the image of God is stamped upon the soul. The separation of the Spirit from the soul at the time of the fall also follows classical theism. Finally, the ontology of humanity calls for the restoration of the image of God through a renewed union of the Holy Spirit with the soul in some way. This restoration begins with the awakening of the spiritual senses of the soul. This is significant for the understanding of divine-human indwelling, because of the link that Wesley makes between the knowledge and love of God with the indwelling of the Spirit. These concepts will be more fully developed in the next section of this dissertation regarding Wesley's understanding of ontological divine-human indwelling.

Now that both Wesley's understanding of the ontology of God and the ontology of humanity has been discussed, it is time to move on to his multifaceted understanding of divine-human indwelling. 


\title{
Ontological Nature of Divine-Human Indwelling
}

\author{
Introduction
}

For Wesley, the indwelling of the Holy Spirit is not some peripheral aspect of the

Christian life, it is at the very center. In fact, Wesley clearly states that without the indwelling of the Spirit the individual cannot be considered as a Christian at all. ${ }^{125}$ Without the Spirit of Christ there is no Christian. This is built right alongside Wesley's emphasis that the image of God has been lost and must be restored and, as presented earlier in this chapter, the image of God is none other than the union of the Holy Spirit with the soul/spirit of the believer. According to Wesley, this union is accomplished by faith, is accomplished with the soul, and without the union the soul/spirit of the individual remains spiritually dead, unable to have spiritual life or discern spiritual things. ${ }^{126}$ Given the central nature of the divine-human indwelling for Wesley, it would only make sense that he himself hungered for this indwelling in a personal experiential way as well as teaching about it. ${ }^{127}$

125 “'Hast thou received the Holy Ghost?' If thou hast not, thou art not yet a Christian. For a Christian is a man that is 'anointed with the Holy Ghost and with power.' Thou art not yet made a partaker of pure religion and undefiled. Dost thou know what religion is? That it is a participation of the divine nature; the life of God in the soul of man; Christ formed in the heart; 'Christ in thee, the hope of glory?' happiness and holiness; heaven begun upon earth? 'a kingdom of God within thee; not meat and drink,' no outward thing; 'but righteousness, and peace, and joy in the Holy Ghost?' an everlasting kingdom brought into thy soul; a 'peace of God, that passeth all understanding;' a 'joy unspeakable, and full of glory?"' Wesley, Awake, 30-31.

${ }^{126}$ Wesley, Awake, 27-28, 32-33; Wesley, Circumcision of the Heart, 202.

127 “At present, I find my soul continually hungering and thirsting after the Spirit's indwelling in me. I often find a solid peace, a serious watchfulness, a presence of mind, never confused or hurried; a sweet communion with God, good-will toward all men, with much grief at their misery, but no fear. I can, with unaccountable boldness, yet with meekness and love, reprove the most daring sinner. And the more I obey this spirit, the more of it I feel; the more sensible I am of my own weakness, and at the same time filled with praise and amazement, to feel my strength in the Lord." John Wesley, Journal from Oct 27, 1743 to Nov 17, 1746, Third ed., The Works of John Wesley, vol. 1 (London: Wesleyan Methodist Bookroom, 1872), 481. 
Wesley describes the divine-human indwelling in many ways, such as: possession and filling, mutual indwelling, spiritual inspiration/breathing, renewal of the image of God, and the witness of the Spirit. In this section of the dissertation all of these expressions will be explored, as well as some other important aspects of Wesley's writings that clarify the nature of divine-human indwelling. These aspects include: the indwelling as Trinitarian in nature, and as unique to the righteous; God as the eschatological end for the human soul; the relationship between love and knowledge as the means for divine-human indwelling; and the role of the sacraments. Once these multiple facets of divine-human indwelling have been explored, a summary and conclusion will present a cohesive explanation of Wesley's understanding of the ontological nature of divine-human indwelling.

\section{Wesley's Indwelling Trinity}

Wesley remained an Anglican all of his life. The separation of Methodism from the Anglican Church was not something that he saw in his lifetime. He may have seen it coming, but it was not something that he pursued, even if his theology and teaching eventually led to it happening. Wesley continued his ties with the Anglican Church, both in his organizational commitment, as well as in much of the traditional theology of that church. It is no surprise, therefore, that Wesley would quote traditional Anglican doctrinal statements in his sermons. For example, in a statement on the forgiveness that is extended to every believer, Wesley included a Trinitarian quote regarding divine-human indwelling by the Father, Son, and Holy Spirit. ${ }^{128}$ This quote reflects a traditional stance

${ }^{128}$ John Wesley, A Farther Appeal to Men of Reason and Religion: Part I, Third ed., The Works of John Wesley, vol. 8 (London: Wesleyan Methodist Bookroom, 1872), 74-75. 
of classical theism, and while it is not a statement made directly in Wesley's own words, it is a passage that he is quoting with agreement.

Wesley's multiple statements regarding the Holy Spirit being represented as the Spirit of the God (Father) and the Spirit of Christ in reference to union with Christ support Wesley's Trinitarian emphasis within his theology. This same Trinitarian emphasis would also extend to divine-human indwelling. ${ }^{129}$ The Holy Spirit still takes the particular role of indwelling for Wesley, as was previously shown in his exposition of the reasons why it is the Holy Spirit who is specifically grieved when the believer turns away from the divine will.

\section{Unique Presence in the Justified}

Wesley affirmed and contended with other theologians of his day that those who were justified had received the Holy Spirit. ${ }^{130}$ He went so far as to ask, if a Christian had not received the Holy Spirit, why would they ever be called a Christian? ${ }^{131}$ The justified, believing Christian enjoys the Holy Spirit as the stamp of the image of God upon their souls. ${ }^{132}$ Both the believer's heart and life is to be shaped by the presence of the Holy

${ }^{129}$ Wesley, First Fruits, 88. Loyer often points to the specifically Trinitarian nature of Wesley's theology. "The foundation of Christian perfection is the one, true God who has opened his life to us in Christ and renews his own loving image in human hearts by the indwelling Spirit such that we are to become 'Transcripts of the Trinity'" Loyer, God's Love through the Spirit, 52.

${ }^{130}$ Wesley, Awake, 33-34.

${ }^{131}$ Collins describes a debate between Wesley and Warburton. Warburton had claimed that there were those who had accepted Christ but because they were not demonstrating their complete transformation to the life of the Spirit they had obviously not actually received the Holy Spirit. Wesley is quick to correct him; "'If men are not Christians till they are renewed after the image of Christ, and if the people of England in general are not thus renewed, why do we term them so?"' Collins, Theology of Wesley, 181. Wesley also discussed this same topic within his Journals. Wesley, Journal from Feb 1, 1738 to August 12, 1738, 117.

${ }^{132}$ Once again, Wesley possibly points towards the formal cause of the Holy Spirit upon the soul showing his classical theism. The integration of the Spirit in the life of the believer also shows evidence of the Holy Spirit as the efficient cause of the development of the soul and transformation of the character. 
Spirit in their souls, which are the temple of that Spirit. ${ }^{133}$

Wesley once again shows his roots in classical theology concerning the unique presence of the Spirit within the justified. Not only had the image of God (the indwelling Holy Spirit) been lost at the time of the fall, as was discussed previously in the ontology of humanity, this image is restored to humanity when they accept by faith the propitiatory sacrifice of Jesus Christ. ${ }^{134}$ For Wesley, only by the Holy Spirit can the transformation of the mind, heart, life, and character be accomplished. ${ }^{135}$ It is by the Spirit that the believer is sealed for salvation and becomes a partaker of the divine nature. ${ }^{136}$

Not only do the just receive the Holy Spirit when they believe, they also can lose the presence of the Holy Spirit if they were to continually resist the will of the Holy Spirit and thus grieve the Holy Spirit. The believer may temporarily cause the Holy Spirit to withdraw his presence from the believer, but if he or she returns to the will of the Spirit in their lives they will remain in Christ and be free from condemnation. ${ }^{137}$ Wesley also stated that it is possible by the continual rejection of the will of the Spirit for the believer to cause the permanent withdrawal of the entire presence of the Holy Spirit from their

\footnotetext{
Wesley, Grieving the HS, 491.

${ }^{133}$ Wesley, Grieving the HS, 486.

134 "'Believe in the Lord Jesus Christ, whom God hath given to be the propitiation for thy sins, and thou shalt be saved;' first, from the guilt of sin, having redemption through his blood; then from the power, which shall have no more dominion over thee; and then from the root of it, into the whole image of God. And being restored both to the favour and image of God, thou shalt know, love, and serve him to all eternity." Wesley, Sermon CIX, 227-230.

${ }^{135}$ Wesley, First Fruits, 89; Wesley, Grieving the HS, 492.

${ }^{136}$ Wesley, Grieving the HS, 490.

${ }^{137}$ Wesley spoke of the possibility of the believer resisting the will of God in such a way that they may for a time find themselves back under condemnation. But as long as they return to Christ they will once again walk after the Spirit and no longer be condemned. Wesley, First Fruits, 90.
} 
lives. ${ }^{138}$ The divine-human indwelling of the Spirit is therefore uniquely for the just, from the moment they accept and believe in Jesus as their savior. The Spirit can carry the believer through to complete salvation as the person continues to believe and remain in Christ or can be caused to leave once again if the believer rejects the will of Christ in their lives.

Classical theism represented by many of the church fathers, presents a similar view of the divine-human indwelling. There is a general presence with all of creation via the providence of God. But there is a unique presence given only to the just. ${ }^{139}$ Wesley remained in agreement with classical theism in this area. ${ }^{140}$

\section{Possession and Filling}

Wesley taught that each Christian, in order to be a Christian, must be filled with the Holy Spirit and spoke against those who suggested that this teaching had no place in sound religion. ${ }^{141}$ For Wesley, to reject that people are moved by the Spirit, feel the

138 "Presumptuous sins are, indeed, in the highest manner offensive to the Holy Spirit of God. They are instances of open enmity against him, and have all the guilt of open rebellion. The willful sinner is not ignorant or surprised, but knowingly fights against God's express commandment, and the lively, full, and present conviction of his own mind and conscience; so that this is the very standard of iniquity. And all other kinds of sins are more or less heinous, as they are nearer or farther off from sins of this dreadful nature; inasmuch as these imply the greatest opposition to God's will, contempt of his mercy, and defiance of his justice. This, if anything can, doubtless, must so grieve him as to make him wholly withdraw his gracious presence." Wesley, Grieving the HS, 490.

${ }^{139}$ Gleason laid out the evidence from the church fathers that there is a special presence for the soul of the just. Gleason, Indwelling Spirit, 16-17. Froget outlines the three levels of presence in the church fathers and Thomas Aquinas; a general presence with all of creation, a special presence within the just soul, and a unique hypostatic union reserved for Jesus Christ. Froget, Indwelling - Thomas Aquinas, 48-49, 54, 63-64.

${ }^{140}$ Wesley himself outlines the difference between the rest of creation and humanity. All of creation lives, moves, and has being within a servile relationship with the creator, but it is only man that can have something other than this world within him. Wesley, Holy Spirit, 511.

${ }^{141}$ Wesley, Awake, 34, 47. 
Spirit, or inspired by the Spirit is to reject all of revelation. For Wesley those who walk with the Spirit are "filled with faith and with the Holy Ghost." 142

There is some discussion about whether this filling is ontological for Wesley. The filling of the Christian with the love of God is not ontological in the sense that the creature would no longer be distinct from the creator. ${ }^{143}$ To be filled with the Spirit for Wesley is to be perfected in love or entirely sanctified. ${ }^{144}$

The filling of the believer with the Holy Spirit may therefore not reflect the ontological union with the soul of the believer as an interpenetration of being. This may be a place of differentiation for Wesley (although he does not explicitly say so) between the filling of the believer with the Holy Spirit and the divine-human indwelling of the Holy Spirit as the image of God stamped upon the soul of justified individuals.

\section{Mutual Indwelling}

Wesley commonly uses phrases associated with mutual indwelling; the believer dwells in God and God dwells in them, they are in Christ and Christ is in them. There are two different levels in Wesley's teaching concerning this mutual indwelling. ${ }^{145}$ The first

\footnotetext{
${ }^{142}$ Wesley, First Fruits, 89.
}

143 "Moreover, by love man is not only made like God, but in some sense [is] one with him. This union of love was not, of course, ontological in the sense that a distinction no longer existed between God and humanity with respect to being; rather it highlighted the goodness, truthfulness, and integrity of the relationship without detracting from the distinctiveness of the persons, so related, in the least. 'As God is love,' Wesley notes, 'so man dwelling in love dwelt in God, and God in him.'" Collins, Theology of Wesley, 52.

${ }^{144}$ Collins, Theology of Wesley, 138. Loyer ties together the language of participation in the discussion of love and the indwelling of the Holy Spirit. The process of sanctification and restoration of the image of God is accomplished through the believer's participation in the love of God through faith by the means of the "indwelling and operations of the Holy Spirit." Loyer, God's Love through the Spirit, 25-26, 44,61 . Wesley wrote concerning the partaking of the Holy Spirit, connected with the obedience to God's commandments and loving God. Wesley, Witness of the Spirit, 120-121.

145 "It required that man should fulfil all righteousness, inward and outward, negative and positive: That he should not only abstain from every idle word, and avoid every evil work, but should keep every 
is the outward signs of this mutual indwelling. Believers living in the righteousness of Christ will demonstrate in their outward life that Christ is in them. They do this by the abstinence from the works of the flesh and disobedience to God as well as the obedience to God and walking according to the Spirit. ${ }^{146}$ Therefore, mutual indwelling has an external behavioral level for Wesley.

The external level, however, is not deep enough for Wesley; it is the motivation behind the external acts where one must look to truly understand what mutual indwelling is. The motivation for the external must be based in the internal knowledge and love of God. ${ }^{147}$ The love for God is lived out in love for one's neighbor, which then requires the external acts of love. ${ }^{148}$ There is an internal hunger and thirst for the righteousness of God, which nothing but the mutual indwelling with God can satisfy. ${ }^{149}$ To be complete in Christ is to be filled with Christ. Mutual indwelling is truly the full possession of the heart of the believer by God. "God is love; and whosoever dwelleth in love, dwelleth in God, and God in him."150

affection, every desire, every thought, in obedience to the will of God: That he should continue holy, as he which had created him was holy, both in heart, and in all manner of conversation: That he should be pure in heart, even as God is pure; perfect as his Father in heaven was perfect: That he should love the Lord his God with all his heart, with all his soul, with all his mind, and with all his strength; that he should love every soul which God had made, even as God had loved him: That by this universal benevolence, he should dwell in God, (who is love,) and God in him: That he should serve the Lord his God with all his strength, and in all things singly aim at his glory." Wesley, Righteousness of Faith, 66.

${ }^{146}$ Wesley, First Fruits, 88-89.

${ }^{147}$ Wesley, Marks of New Birth, 219-220.

${ }^{148}$ Wesley, Marks of New Birth, 219-220.

${ }^{149}$ For Wesley, The satisfaction of the thirsty soul will be met eschatologically when the just soul is completely in union with God. Wesley, Sermon on the Mount II, 267-268.

150 “And when we are $\varepsilon v \alpha v \tau \omega \omega \varepsilon \pi \lambda \eta \rho \omega \mu \varepsilon v o 1$, complete in him, as our translators render it; but more properly when we are filled with him; when 'Christ in us, the hope of glory,' is our God and our All; when he has taken the full possession of our heart; when he reigns therein without a rival, the Lord of every motion there; when we dwell in Christ, and Christ in us, we are one with Christ, and Christ with us; then 
Mutual indwelling is a key idea in the discussion of the ontological nature of divine-human indwelling. For classical theism, mutual indwelling is also important and Wesley once again demonstrated his agreement with classical theism by using the key terms of knowledge and love, which will be discussed more a little later. ${ }^{151}$ All of creation enjoys the general presence of God, but the just soul enjoys the special presence of the Holy Spirit within the soul by the love and knowledge of God. Through his language regarding mutual indwelling, Wesley once again agreed with classical theism.

\section{Inspiration/Breathing}

Related to mutual indwelling is what Wesley calls spiritual respiration. When a person has accepted Christ, and is spiritually reborn, the breath or Spirit of God enters the soul of the believer, as it has been breathed into the soul. The spiritual senses are awakened and the soul is now responsive to the Spirit in their life. ${ }^{152}$ Wesley does not mean inspiration in the sense of the inspiration of the biblical writers, but rather in a communal sense of mutual respiration between God and the soul. ${ }^{153}$ Wesley spoke of the Spirit being breathed into the soul from God and the believer breathing this same spirit

we are completely happy; then we live 'all the life that is hid with Christ in God;' then, and not till then, we properly experience what that word meaneth, 'God is love; and whosoever dwelleth in love, dwelleth in God, and God in him." Wesley, Spiritual Worship, 430-431. Loyer suggests that happiness for the believer is based on the mutual indwelling with the entire Trinity for Wesley. Loyer, God's Love through the Spirit, 54 .

${ }^{151}$ Divine-human indwelling, for the scholars debating the understanding of Aquinas, is based upon these terms. See Chapter 1 of this dissertation.

${ }^{152}$ Wesley, Privilege, 269.

153 'It is important to clarify what Wesley intended by 'inspiration' in this context. The word often functions in Western theology as a technical term designating a cognitive influence of the Holy Spirit, particularly upon the writers of Scripture. Wesley is not using the term in this sense here. He is intending something more like the basic meaning of the Latin original, inspirate: to breathe into, animate, excite, or inflame.' In fact, he defined 'inspiration' in his Dictionary simply as the (restored) influence of the Holy Spirit that enables persons to love and serve God." Maddox, Responsible Grace, 121-122. 
back to God through love, praise, and prayer. Wesley clarified the love, praise, and prayer as the thoughts, words, and actions of the believer returned in service to God as living sacrifices, especially with reference to Romans $12: 1 .^{154}$

This divine respiration, for Wesley, is a constant action of "God upon the soul and the soul upon God."155 This deepens the explanation of the unique experience of the presence of God for the just. The action of the presence of God upon the soul once again is a reminder of the stamp of the image of God upon the soul. The indwelling Spirit is the cause which shapes the soul so that the respiration returned to God is one of a transformed life in thought, word, and deed. ${ }^{156}$ The constant communion of spiritual respiration would incrementally form the believer towards the goal of entire sanctification, or the full restoration of the image of God. ${ }^{157}$

\section{Eschatological End}

For Wesley, the presence of the Holy Spirit in the soul and life of the believer is

\footnotetext{
154 "It immediately and necessarily implies the continual inspiration of God's Holy Spirit; God's breathing into the soul, and the soul's breathing back what it first receives from God; a continual action of God upon the soul, and a re-action of the soul upon God; an unceasing presence of God, the loving, pardoning God, manifested to the heart, and perceived by faith; and an unceasing return of love, praise, and prayer, offering up all the thoughts of our hearts, all the words of our tongues, all the works of our hands, all our body, soul, and spirit, to be a holy sacrifice, acceptable unto God in Christ Jesus." Wesley, Privilege, 232-233.

155 Wesley, Privilege, 232-233.

${ }^{156}$ Collins uses this phrase of Wesley to speak of the empowering presence of God upon the hearts of the believers so that they might engage in "divine/human cooperation." He goes on to show Wesley's insistence that if this reciprocal influence or respiration is not given, the believer may lose the gifts or talents that God has already given them. Collins, Theology of Wesley, 203.

157 "God is continually breathing, as it were, upon his soul, and his soul is breathing unto God. Grace is descending into his heart, and prayer and praise ascending to heaven. And by this intercourse between God and man, this fellowship with the Father and the Son [1 Jn 1:3], as by a kind of spiritual respiration, the life of God in the soul is sustained: and the child of God grows up, till he comes to 'the full measure of the stature of Christ' [Eph 4:13]." Loyer, God's Love through the Spirit.
} 
an ever-deepening process. This is demonstrated in the continual communion of spiritual respiration, as well as the eschatological end of the soul. Wesley describes God as the teleological end for the soul. The desire of the soul in worship should only be for God as he is "the end of all souls he has made." The believer is to set aside any other thing that might become an idol for the believer. ${ }^{158}$

Wesley understood the spiritual immortality of the soul to be a complete transformation of the person from physical to spiritual. There will come a time for Wesley when the physical animal body, when reborn with the soul, will become completely spiritual. ${ }^{159}$ There will come a time with the flesh of the believer when it will accept the "divine guest" within and therefore be completely transformed into a "house from heaven."160

The divine-human indwelling at this point in time for the believer is only a deposit of the future divine indwelling. Humans are being prepared by degrees to "be accustomed to receive and carry God within us." Wesley spoke of a time when the mortal will be "swallowed up" by immortality, when the believer will be made "like unto God." 161 It seems clear that Wesley does intend an ontological union of the divine-human indwelling in a progressive nature which will eventually transform the believer into a completely spiritual state of being as the eschatological end.

\footnotetext{
${ }^{158}$ Wesley, Spiritual Idolatry, 436.

${ }^{159}$ Wesley, Holy Spirit, 515.

${ }^{160}$ Wesley, Holy Spirit, 516.

${ }^{161}$ Wesley, Holy Spirit, 517.
} 


\section{Knowledge and Love}

For Wesley, the new birth of the believer is one that is accomplished by the Holy Spirit awakening the spiritual senses of the soul so that it is capable of the knowledge and love of God. ${ }^{162}$ But in order for the soul to remain alive the mutual exchange of divine respiration must occur. The knowledge and love of God, initially enabled by the presence of the Holy Spirit in the heart of the believer, must be reciprocated by the believer choosing to return this love to God. ${ }^{163}$ One of the primary ways that Wesley speaks about the divine-human indwelling relationship is with regards to the love of God being poured by the Holy Spirit into the heart of the believer. ${ }^{164}$

Yet Wesley also holds up the paradox of the holy-yet-not-holy person as the temple of the Holy Spirit. ${ }^{165}$ It would seem that the Holy Spirit could not dwell where there is sin in the life of the believer. It would seem that entire sanctification would be necessary for a holy God to be able to dwell within a human heart or soul. And yet

162 "His ears are now opened, and the voice of God no longer calls in vain. He hears and obeys the heavenly calling: He knows the voice of his Shepherd. All his spiritual senses being now awakened, he has a clear intercourse with the invisible world; and hence he knows more and more of the things which before it could not 'enter into his heart to conceive.' He now knows what the peace of God is; what is joy in the Holy Ghost; what the love of God which is shed abroad in the hearts of them that believe in him through Christ Jesus. Thus the veil being removed which before intercepted the light and voice, the knowledge and love of God, he who is born of the Spirit, dwelleth in love, 'dwelleth in God, and God in him." Wesley, Privilege, 150-151. Wesley, Living without God, 354. Loyer confirms this as well: "Wesleys account of the spiritual senses affirms the basic principle that human knowledge of God is ultimately a matter of divine revelation. Knowledge of God is possible for human beings only through a disclosure of saving truths by God and about God, truths that are accessible through actual human experience of God under grace. For Wesley, Gods definitive revelation is given in Christ to whom Scripture bears witness, and it is confirmed by Gods direct address to Christian believers through their spiritual senses, which are awakened and sustained by the influences of the Holy Spirit." Loyer, God's Love through the Spirit, 40.

${ }^{163}$ Wesley, Privilege, 152.

${ }^{164}$ Wesley, Living without God, 352; Wesley, Privilege, 233; Collins, Theology of Wesley, 124.

${ }^{165}$ Wesley, Sin in the Believer, 146-152. 
Wesley is clear that the believer still struggles with the being of $\sin .{ }^{166} \mathrm{He}$ or she may

have been delivered from the guilt and power of sin, but the being of sin is still something

that the believer struggles against. The knowledge and love of God is not fully perfected

in the believer. Wesley, however, insists that it is only by the indwelling Spirit that the

believer has begun the process of becoming holy. ${ }^{167}$ Therefore, the Holy Spirit must be

dwelling within the believer, even though there is still sin to be removed.

Wesley's use of language once again reflects his ties to classical theism in relation

to the ontological nature of divine-human indwelling. The Holy Spirit must be present in

order to cause any sort of holiness, love, or knowledge of God. Those who debate the

ontological nature of divine-human indwelling within the writings of Thomas Aquinas do

so with the language of the knowledge and love of God. ${ }^{168}$ It is by the knowledge and the

166 Wesley, Sin in the Believer, 152.

167 'For the text affirms this, and no more,- - that every man who is 'born of the Spirit,' is a spiritual man. He is so: But so he may be, and yet not be altogether spiritual. The Christians at Corinth were spiritual men; else they had been no Christians at all; and yet they were not altogether spiritual: They were still, in part, carnal._- 'But they were fallen from grace.' St. Paul says, No. They were even then babes in Christ. 2. 'But a man cannot be clean, sanctified, holy, and at the same time unclean, unsanctified, unholy.' Indeed he may. So the Corinthians were. 'Ye are washed,' says the Apostle, 'ye are sanctified;' namely, cleansed from 'fornication, idolatry, drunkenness,' and all other outward sin; (1 Cor 6:9, 10, 11;) and yet at the same time, in another sense of the word, they were unsanctified; they were not washed, not inwardly cleansed from envy, evil surmising, partiality.- 'But sure, they had not a new heart and an old heart together.' It is most sure they had, for, at that very time, their hearts were truly, yet not entirely, renewed. Their carnal mind was nailed to the cross; yet it was not wholly destroyed.- 'But could they be unholy while they were 'temples of the Holy Ghost?' Yes; that they were temples of the Holy Ghost, is certain; (1 Cor 6:19;) and it is equally certain, they were, in some degree, carnal, that is, unholy." Wesley, Sin in the Believer, 150-151. Collins speaks of this process of the transforming work of the Holy Spirit in Wesley as a qualitative change by which the believer is thus named holy, "To be sure, the presence of the Holy Spirit in the heart at the new birth in an array of efficacious graces results not in an incremental change, that is, one of degree, but a qualitative change, that of a transformed nature such that believers become what they have never been before properly speaking, namely, holy." This "qualitative" changes points towards the classical theism understanding of divine-human indwelling being some sort of substantive union and change.

Collins, Theology of Wesley, 124-125.

${ }^{168}$ Loyer uses the love and knowledge language in Wesley, in connection with the language of Aquinas, as describing Wesley's understanding that through knowledge and love the love of God is in full possession of the heart of the believer. Loyer, God's Love through the Spirit, 53-54. 
love of God that the just have a special presence of the indwelling Spirit of God united with their souls, which the rest of general creation does not have. Wesley seems to be reflecting the same kind of sentiment. The knowledge and love of God shows that the Holy Spirit is present as the efficient cause of the awakening of the soul. Without the presence of the Spirit, knowledge and love would not be possible, therefore knowledge and love of God in the believer is clear evidence that the divine Holy Spirit is indeed indwelling the human heart/soul.

\section{Happiness}

Related to the knowledge and love of God mentioned above, Wesley gives substance to happiness. ${ }^{169}$ It is only through the indwelling of the Holy Spirit that the believer can be enlivened to the knowledge and love of God, as mentioned previously, in the same way only through the presence of the Holy Spirit can a person be happy. Once the indwelling is established, then a true substantial happiness is found in the soul. Wesley held that God is the only source of true happiness and because all Christians have the Holy Spirit, as mentioned previously, therefore all Christians are also happy. Wesley, in fact, identifies religion with happiness. For a person is happy if they are indeed a Christian. ${ }^{170}$ The loss of happiness is part of the fallen condition, for Wesley, and the only

169 "This eternal life then commences when it pleases the Father to reveal his Son in our hearts; when we first know Christ, being enabled to 'call him Lord by the Holy Ghost;' when we can testify, our conscience bearing us witness in the Holy Ghost, 'The life which I now live, I live by faith in the Son of God, who loved me, and gave himself for me.' And then it is that happiness begins; happiness real, solid, substantial. Then it is that heaven is opened in the soul, that the proper heavenly state commences, while the love of God, as loving us, is shed abroad in the heart, instantly producing love to all mankind; general, pure benevolence, together with its genuine fruits, lowliness, meekness, patience, contentedness in every state; an entire, clear, full acquiescence in the whole will of God; enabling us to 'rejoice evermore, and in everything to give thanks." (emphasis added) Wesley, Spiritual Worship, 431.

${ }^{170}$ Wesley does leave room for exceptions to the happiness of Christians if there are mental illnesses involved, which the devil may add to by the use of his "fiery darts." Wesley, Spiritual Worship, 
source of happiness to be found is in the return of the soul to God. ${ }^{171}$ When this happiness has been established, then heaven is open to the soul. ${ }^{172}$

It seems that Wesley ties a substantial reality within the soul of the believer with happiness. This is accomplished through divine-human indwelling and is only substantially possible with divine-human indwelling; otherwise the happiness that may be found by an individual is only temporary and will fade away, it is not actually substantive. ${ }^{173}$ This once again points to a unique presence for the just, the substantive happiness produced by the divine-human indwelling is only found in the Christian and, in fact, is significantly related to what it means to be a Christian. Classical theism is demonstrated once more in Wesley because divine-human indwelling is not panentheistically constant for all creatures, nor is the substantive happiness which it produces.

\section{Renewal of the Image of God}

Much of Wesley's understanding regarding man being made in the image of God was already covered in the section of this chapter regarding the ontology of humanity. It is significantly tied in with the divine-human indwelling of the Holy Spirit, however, and

433-434.

\footnotetext{
${ }^{171}$ Wesley, Spiritual Worship, 434. Wesley, Single Eye, 300-301.

${ }^{172}$ Wesley, Spiritual Worship, 431.
}

173 "And we may learn from hence, First, that as there is but one God in heaven above and in the earth beneath; so there is only one happiness for created spirits, either in heaven or earth. This one God made our heart for himself; and it cannot rest till it resteth in him. It is true, that while we are in the vigour of youth and health; while our blood dances in our veins; while the world smiles upon us, and we have all the conveniences, yea, and superfluities of life, we frequently have pleasing dreams, and enjoy a kind of happiness. But it cannot continue; it flies away like a shadow; and even while it does, it is not solid or substantial; it does not satisfy the soul.” Wesley, Spiritual Worship, 431. 
will, therefore, be developed further in this section. Humanity was created in the image of God originally and Wesley identifies that image of God with God's Spirit. ${ }^{174}$

Wesley also makes other statements about what the image of God "is," namely righteousness. ${ }^{175}$ The image of God is righteousness which is seen both in the internal transformation of the soul as well as the external actions of the individual. ${ }^{176}$ The lack of righteousness, both internally and externally, is the loss of the image of God. This image of God is only restored by the Holy Spirit. The Holy Spirit is the seal or stamp upon the heart/soul of the believer. ${ }^{177}$ The Spirit is the formal cause of restoring the righteous image of God in the believer. The Holy Spirit is, for Wesley, also the efficient cause for the restoration of the image of God in the believer. Only by the work of the Holy Spirit is the believer able to perceive the knowledge of the love of God when his or her spiritual senses are awakened. ${ }^{178}$ Without the divine-human indwelling work of the Holy Spirit

${ }^{174}$ Wesley, Holy Spirit, 509.

${ }^{175}$ Wesley, Semon on the Mount I, 256-257.

${ }^{176}$ Wesley pointed to the internal nature of the restoration of the image of God as the writing of the commandments of God upon the heart of the believer, "The righteousness, then, which is of the law, speaketh on this wise: 'Thou, O man of God, stand fast in love, in the image of God wherein thou art made. If thou wilt remain in life, keep the commandments, which are now written in thy heart." Wesley,

Righteousness of Faith, 67-68. Wesley also stated that the change of the soul is so significant that it is as if the soul were of another world, "The former changes our outward relation to God, so that of enemies we become children; by the latter our inmost souls are changed, so that of sinners we become saints. The one restores us to the favour, the other to the image, of God...; but a vast inward change, a change wrought in the soul, by the operation of the Holy Ghost; a change in the whole manner of our existence; for, from the moment we are born of God, we live in quite another manner than we did before; we are, as it were, in another world. Wesley, Privilege, 223-224. While the writing of the laws upon the heart of the believer might be considered simply a moral union of the believer with God, the language of changing the whole manner of existence indicates an ontological union and change.

177 Wesley, Semon on the Mount I, 256-257.

178 "So it is with him that is born of God. Before that great change is wrought, although he subsists by Him, in whom all that have life 'live, and move, and have their being,' yet he is not sensible of God; he does not feel, he has no inward consciousness of His presence. He does not perceive that divine breath of life, without which he cannot subsist a moment: Nor is he sensible of any of the things of God; they make no impression upon his soul." Wesley, Privilege, 225-226. 
there is no restoration of the image of God. This restoration is the work of sanctification in the life of the believer, which is the primary responsibility of the Holy Spirit as the Spirit is the most directly present by indwelling the believer. ${ }^{179}$

It is also important to state once again that, for Wesley, the presence of the divinehuman indwelling of the Holy Spirit (which constitutes the image of God) is a presence which can be and was lost at the fall. ${ }^{180}$ The soul is not even able to respond to or recognize the general sustaining divine presence in the life of the individual without the work of the Holy Spirit to re-awaken the spiritual senses. ${ }^{181}$ As mentioned in the previous discussion regarding the image of God, the possibility of separation from the presence of God, both concerning the divine-human indwelling of the present time and the eternal eschatological separation of hell, demonstrate Wesley's non-essentially inclusive version of classical theism.

\section{Holy Spirit and the Kingdom}

For Wesley, the kingdom of heaven, the peace of God, and the joy of the Lord are all produced in the life of the believer by the divine-human indwelling of the Holy Spirit

179 "Justification, or pardon through the blood and righteousness of Christ, denotes (as Wesley elsewhere describes) 'what God does for us through his Son,' while sanctification, the inward renewal produced by the Holy Spirit, signifies 'what [God] works in us through his Spirit' Justification restores us 'to the favour, [sanctification] to the image of God.'" Loyer, God's Love through the Spirit, 49.

180 "In the beginning, the heavenly Word, -- being a Spirit that issued from the Father, and the Word of his power, -- made man an image of immortality, according to the likeness of the Father; but he who had been made in the image of God, afterwards became mortal, when the more powerful Spirit was separated from him." Wesley, Holy Spirit, 512-513. This separation can become permanent and eternal, "They will then know and feel, that God alone is the centre of all created spirits; and, consequently, that a spirit made for God can have no rest out of him. It seems that the Apostle had this in his view when he spoke of those 'who shall be punished with everlasting destruction from the presence of the Lord.' Banishment from the presence of the Lord is the very essence of destruction to a spirit that was made for God. And if that banishment last for ever, it is "everlasting destruction."' Wesley, Hell, 384.

181 Wesley, Privilege, 225-226. 
in the soul. ${ }^{182}$ This is an internal kingdom through which heaven has been, to a degree, opened to the soul of the believer. ${ }^{183}$ The kingdom of God within the soul is, however, a consequence of the indwelling of the Holy Spirit, rather than identified with the indwelling of the Holy Spirit. ${ }^{184}$

\section{Witness of the Spirit}

One of Wesley's most frequently used expressions to speak of divine-human indwelling was the witness of the Spirit, taken from Romans Chapter $8 .{ }^{185}$ One of Wesley's two points, in his sermon The Witness of the Spirit, was to define what the witness might be. ${ }^{186}$ He was careful to express that these deep things of God cannot truly be understood or explained with any sort of philosophical prowess. ${ }^{187} \mathrm{He}$ did however give some suggestions as to what the witness might be. Wesley's repeated phrase of

182 "This holiness and happiness, joined in one, are sometimes styled, in the inspired writings, 'the kingdom of God,' (as by our Lord in the text,) and sometimes, 'the kingdom of heaven.' It is termed 'the kingdom of God,' because it is the immediate fruit of God's reigning in the soul. So soon as ever he takes unto himself his mighty power, and sets up his throne in our hearts, they are instantly filled with this 'righteousness, and peace, and joy in the Holy Ghost.' It is called 'the kingdom of heaven,' because it is (in a degree) heaven opened in the soul." Wesley, Way of the Kingdom, 80-81.

${ }^{183}$ Collins discusses Wesley's view on the internal nature of the kingdom, as well as coming to similar conclusions, suggesting that the kingdom is implanted in the soul of the believer. Collins, Theology of Wesley, 126-127.

184 “'And 'except a man be' thus 'born again, he cannot see the kingdom of God.' But all who are thus 'born of the Spirit' have 'the kingdom of God within them." Wesley, Death of George Whitefield, 179. Wesley, Journal from Nov 1, 1739 to September 3, 1741, 250.

${ }^{185}$ Wesley, Salvation by Faith, 14; Wesley, Way of the Kingdom, 39-40; Wesley, First Fruits, 90; Wesley, Spirit of Bondage, 110; Wesley, Witness of the Spirit, 112-132; Wesley, Witness of Our Own Spirit, 138-139, 141-142; Wesley, Spiritual Worship, 430; Wesley, Single Eye, 298.

${ }^{186}$ Wesley, Witness of the Spirit, 112.

187 "To require a more minute and philosophical account of the manner whereby we distinguish these, and of the criteria, or intrinsic marks, whereby we know the voice of God, is to make a demand which can never be answered; no, not by one who has the deepest knowledge of God." Wesley, Witness of the Spirit, 121. 
definition of the witness of the Spirit is: an "inward impression upon the soul."188 This impression upon the soul of the just is one which softens the soul of believers so they are enabled to accept the love of God from the testimony of the Spirit that they are indeed the children of God. ${ }^{189}$

There are two ontological suggestions made in the phrase "inward impression upon the soul." The first is the testimony of the Spirit as a formal cause upon the soul, which softens the soul enough that it might have heaven opened to it and that it might be reformed into the image of God. ${ }^{190}$ The second ontological suggestion of this phrase found in Wesley is one of an efficient cause. Wesley is clear that the gifts of the spirit come to each person who accepts the purchase of Christ's blood for their lives. ${ }^{191}$ The

${ }^{188}$ Wesley, Witness of the Spirit, 119, 124-125, 132; Wesley, Witness of Our Own Spirit, 138.

189 "I observed many years ago, 'It is hard to find words in the language of men, to explain the deep things of God. Indeed there are none that will adequately express what the Spirit of God works in his children. But perhaps one might say, (desiring any who are taught of God, to correct, soften, or strengthen the expression, ) By the testimony of the Spirit, I mean, an inward impression on the soul, whereby the Spirit of God immediately and directly witnesses to my spirit, that I am a child of God; that Jesus Christ hath loved me, and given himself for me; that all my sins are blotted out, and I, even I, am reconciled to God." Wesley, Witness of the Spirit, 124-125.

${ }^{190}$ Wesley, Witness of Our Own Spirit, 141-142. A formal cause is compared to a seal pressing into wax by the church fathers when describing the indwelling of the Holy Spirit. A formal cause is the cause that is the form which the impressed soul is being formed into. The efficient cause could also be called the instrumental cause. In the case of a sculpture the efficient cause is artisan or instruments that he or she is using shape the stone. In the case of indwelling the Holy Spirit is the agent who brings about the effects of character change and development within the believer.

${ }^{191}$ Wesley also connects the witness of the Spirit to the witness of the Spirit through Scripture. That Scripture is a part of the testimony of the Spirit so that believers can know they are children of God. The efficient cause of the Holy Spirit is demonstrated by the necessity of the fruits of the Spirit which validate the testimony as true. "But what is the witness of the Spirit? The original word $\mu \alpha \rho \tau \rho \rho \alpha$, may be rendered either (as it is in several places) the witness, or less ambiguously, the testimony, or the record: So it is rendered in our translation, (1 John 5:11,) 'This is the record,' the testimony, the sum of what God testifies in all the inspired writings, 'that God hath given unto us eternal life, and this life is in his Son.' The testimony now under consideration is given by the Spirit of God to and with our spirit: He is the Person testifying. What he testifies to us is, "that we are the children of God." The immediate result of this testimony is, 'the fruit of the Spirit;' namely, 'love, joy, peace, long-suffering, gentleness, goodness:' And without these, the testimony itself cannot continue. For it is inevitably destroyed, not only by the commission of any outward sin, or the omission of known duty, but by giving way to any inward sin; in a 
presence or witness of the Spirit upon the soul of the believer produces the inward transformation of the believer and the outward signs of the fruit of the Spirit.

The witness of the Spirit is also related to the knowledge and love of God, which was discussed in the previous section. Wesley stated that the only way that a believer could know of their love of God and recognize that they were a child of God was because God had loved them first and it is the witness of the Spirit that allows them to be open to that knowledge and to love God in return. ${ }^{192}$ This relationship brings in another part of Wesley's discourse on the witness of the Spirit and that is the insistence that there is a witness both of the Spirit of God and of the human spirit. Wesley wrote that he was tempted to see this statement in Romans as solely the witness of the Holy Spirit and not of the human spirit as well. But the evidence from other places in Scripture clarified for Wesley that the human spirit is also able to attest to the validity that a believer is a child of God. ${ }^{193}$ This is seen as an assurance of salvation and demonstrated by the fruit of the Spirit and obedience in the life of the believer. ${ }^{194}$

word, by whatever grieves the Holy Spirit of God.” Wesley, Witness of the Spirit, 124, 125-126.

Wesley tied the witness of the spirit with the purchase of the blood of the Lamb, thus giving the witness of the Spirit only to the just believer. "This is properly the ground of a Christian's joy. We may now therefore readily conceive, how he that hath this testimony in himself rejoiceth evermore. 'My soul,' may he say, 'doth magnify the Lord, and my spirit rejoiceth in God my Saviour.' I rejoice in him, who, of his own unmerited love, of his own free and tender mercy, 'hath called me into this state of salvation,' wherein, through his power, I now stand. I rejoice, because his Spirit beareth witness to my spirit, that I am bought with the blood of the Lamb; and that, believing in him, 'I am a member of Christ, a child of God, and an inheritor of the kingdom of heaven." Wesley, Witness of Our Own Spirit, 141-142.

${ }^{192}$ Wesley, Witness of the Spirit, 127.

${ }^{193}$ Wesley, Witness of the Spirit, 113-114.

${ }^{194}$ Wesley once again highlighted the law being written upon the heart of the believer, in connection with the witness of the Spirit and the fruits which are produced through this witness. Wesley, Witness of the Spirit, 113-114. Wesley, Witness of Our Own Spirit, 138-139. 
The witness or testimony of the Spirit with the human spirit is a clear demonstration of Wesley's view of the ontological nature of divine-human indwelling. While he is not willing to say he truly understands what the witness of the spirit is in philosophical terms, his descriptions of what the witness is points both to a formal and efficient causal relationship between the Spirit of God and the human spirit. Wesley also demonstrated classical theism's understanding of divine-human indwelling by once again calling attention to the witness of the Spirit being something unique to the just believer and lacking from the person who rejects God. For the believer, the witness of the Spirit is an assurance of salvation, while this attempt of God's love to enter the soul glances off of the unwilling person. ${ }^{195}$

\section{Sacraments}

Wesley demonstrated his classical theism in his statements on the sacraments as the outward means of the grace of God being "conveyed" "into the souls of men." ${ }^{196} \mathrm{He}$ described the primary, or the outward means, as being prayer and the study of Scripture, but then he also included the Eucharist as well. ${ }^{197} \mathrm{He}$ is clear that these outward means

195 "But suppose there were added to all this a deep conviction of sin, with much fear of the wrath of God; vehement desires to cast off every sin, and to fulfil all righteousness; frequent rejoicing in hope, and touches of love often glancing upon the soul; yet neither do these prove a man to be under grace; to have true, living, Christian faith, unless the Spirit of adoption abide in his heart, unless he can continually cry, 'Abba, Father!'” Wesley, Spirit of Bondage, 110. Woodrow W. Whidden II speaks of Wesley's use of the witness of the Spirit as God speaking directly to the soul as an assurance of the grace that has been given for the election of those who have chosen it, leading to an understanding of the deeper things of salvation. This assurance of personal election, Whidden points out, is also demonstrated in the outward signs of the believer's life through the fruit of the Spirit. Whidden, Judgement and Assurance, 99-100. Maddox also writes of Wesley's use of the witness of the spirit to communicate the assurance of salvation in a clear, conscious evidence by the fruits of the Spirit in the life of the believer. Maddox points to the prevenient grace, which the witness of the Spirit conveys to the believer, thus saving Wesley both from a works-based salvation and spiritual enthusiasm. Maddox, Responsible Grace, 124, 129-130.

196 Wesley, Means of Grace, 185-188.

197 "The chief of these means are prayer, whether in secret or with the great congregation; searching the Scriptures; (which implies reading, hearing, and meditating thereon;) and receiving the 
have no value without the Holy Spirit. It is only by the Spirit that there is power to save and without the Holy Spirit no grace is conveyed to the soul. There must be faith in Christ for the Holy Spirit to convey the grace to the soul and even if a person is cut off from the outward means of the bread and the cup, they may still receive grace by the Holy Spirit. ${ }^{198}$

Although Wesley is not specific in his philosophical terms here and refuses to be so, as was demonstrated in relation to the witness of the Spirit, a connection to the system of classical theism can be seen in his words on the sacraments. The conveyance of grace into the soul is similar to the idea of the soul gaining an accidental union with the grace of God which then allows for the presence of the Holy Spirit to enter into and indwell the soul. Wesley does not claim this relationship in explicit terms, as some of the church fathers did, as demonstrated in Chapter 1 of this dissertation; but there are hints of this kind of thinking.

\section{Summary and Conclusion}

This second chapter of the dissertation has analyzed and described Wesley's understanding of the ontology of God, the ontology of humanity, and the suggested understanding of the ontological nature of divine-human indwelling in Wesley's multifaceted description of divine-human indwelling. From these categories of

Lord's supper, eating bread and drinking wine in remembrance of Him: And these we believe to be ordained of God, as the ordinary channels of conveying his grace to the souls of men." Wesley, Means of Grace.

198 "Settle this in your heart, that the opus operatum, the mere work done, profiteth nothing; that there is no power to save, but in the Spirit of God, no merit, but in the blood of Christ; that, consequently, even what God ordains, conveys no grace to the soul, if you trust not in Him alone. On the other hand, he that does truly trust in Him, cannot fall short of the grace of God, even though he were cut off from every outward ordinance, though he were shut up in the centre of the earth." Wesley, Means of Grace, 201. 
comparison, it has been demonstrated that he viewed God as an omnipresent Trinitarian spirit who is distinct and yet present with and around all of his creation in a providential manner. Also, humanity has a dualistic ontology in the combination of a temporal body with an immortal soul. Humanity was made in the image of God, which is the indwelling of the Holy Spirit and has moral, physical (both having immortal spirits), and political effects within the individual person. This image has been lost, however, meaning that the union with God through the indwelling Holy Spirit has been severed and must be restored through the process of salvation. Wesley's multifaceted expression of divine-human indwelling can be summarized as the indwelling of the Holy Spirit in the soul of the just believer, both as a formal and efficient cause. This indwelling brings about the assurance of salvation through the witness of the Spirit that the believer is a child of God and the evidence of that efficient cause seen in the knowledge and love of God demonstrated by the fruit of the spirit in the life of the believer.

The classical language of the formal and efficient causes for the ontological nature of divine-human indwelling are used in the scholarly debates, described in chapter 1 of this dissertation, to argue for a substantial union of the divine and human beings/realities. Wesley's use of this language suggests that he believed in a substantial interpenetration of the divine being within the being of the human soul.

This view of the ontological nature of divine-human indwelling is in line with the model of classical theism in several ways: first, the indwelling of the Holy Spirit is only available to the just; second, the indwelling of the Holy Spirit is the formal and/or efficient cause of the soul being transformed into the image of God; thirdly the indwelling divine presence of the Holy Spirit can be and was removed from the souls of 
humanity at the fall; and finally, the indwelling is Trinitarian based on the Trinitarian ontology of God.

Throughout the chapter I have pointed out the connections which Wesley's theology has with classical theism, starting with Wesley's theological background and then throughout each section. This is for the purpose of a strong comparison between the classical theistic system of understanding the ontological nature of divine-human indwelling represented by Wesley and Cobb's panenetheistic system of understanding the ontological nature of divine-human indwelling represented by Cobb. ${ }^{199}$ It is also significant because of the attempt of Cobb to interpret Wesley according to his own panentheistic views. ${ }^{200}$

In order to better understand the differences between Wesley's classical theistic understanding of divine-human indwelling and Cobb's panentheistic view, it is necessary to more fully analyze Cobb's understanding, which will be done in the next chapter of this dissertation.

${ }^{199}$ Discussed in Chapter 3 of this dissertation.

${ }^{200}$ Discussed in Chapter 4 of this dissertation. 


\section{CHAPTER 3}

\section{JOHN B. COBB JR.'S UNDERSTANDING OF THE ONTOLOGICAL NATURE OF DIVINE-HUMAN INDWELLING}

\section{Introduction}

This chapter presents John Cobb's interpretation of the ontological nature of divine-human indwelling according to the same pattern found in Chapter 2 on Wesley's interpretation. This chapter includes an introduction to John Cobb through a biographical sketch and a description of his methodology. The next section contains the comparison of the research categories set out in the method for this dissertation; the ontology of God, the ontology of humanity, and the ontology of divine-human indwelling. ${ }^{1}$ Finally, a summary and conclusion regarding Cobb's interpretation of divine-human indwelling is presented as the representative panentheistic model for this dissertation.

\section{John B. Cobb Jr.’s Biographical Sketch and Theological Method}

John B. Cobb Jr. was born February 9, 1925 in Japan to Methodist missionaries John and Theodora. After spending his early years back and forth between Georgia and Japan, Cobb found himself at Emory for junior college and then in the United States Army for World War II. He was selected for the Japanese language program and spent time with Jews and Irish Catholics. The time spent with these fellows in the army made

\footnotetext{
${ }^{1}$ For further reference, Chul Ho Youn also works through the first two categories of comparison in his dissertation specifically in reference to God's relationship to the world in part II of his dissertation and God's relation to human existence in part III of his dissertation. His work is done by comparing Cobb with Paul Tillich. This dissertation will focus on Cobb's own writing rather than Youn's work for the sake of primary source veracity. Chul Ho Youn, "God's Relation to the World and Human Existence in the Theologies of Paul Tillich and John B. Cobb, Jr.” (Dissertation, Northwestern University, 1990).
} 
Cobb aware of the various religious positions that challenged his pietism. His faith remained strong, however, so he decided he wanted a greater challenge. He enrolled in an integrated program at the University of Chicago so that he could face the modernist challenges to the Christian faith head on. The modernist challenges regarding the view of reality shattered his Christian faith. A once close experiential based relationship with a God whose presence he had experienced was lost.

Cobb turned his disillusioned faith, shattered by modernity, to modern religion to find some answers. Engaging study at University of Chicago Divinity School, he was introduced to the Process philosophy of Alfred N. Whitehead via Charles Hartshorne. Whitehead's process philosophy became the foundation for Cobb's theological construction throughout his life time. The stages of construction included the metaphysics of reality and systematic theology, application of process theology to ecological and sociopolitical concerns, and engaging dialogue with feminist theology and Buddhism alike.

Professionally, after a short stop at Emory, Cobb followed Ernest Colwell to Claremont school of Theology where he started both a journal, Process Studies, and the Center for Process Studies with David Griffin. He is still teaching and writing now in his nineties. $^{2}$

This biographical sketch demonstrates the motivation for Cobb's theological method. An understanding of his methodology will assist the reader to better grasp the reasons for the differences between the theological understandings of indwelling

\footnotetext{
${ }^{2}$ All of the information for this biographical sketch can be found in David Griffin's article on Cobb's theological biography. Griffin, "Cobb: A Theological Biography," 225-240.
} 
expressed by two "Methodist" theologians. Just as much of Wesley's background

influenced his methodological use of the Quadrilateral, so Cobb's method is influenced

by his own process of experience and thought.

One of the most direct statements of Cobb's method comes from his commentary

on Romans. In this study, he and David Lull define the "we" they refer to, as they write,

to include themselves as Methodists, who are both influenced by the process philosopher

Alfred North Whitehead, and the community they ascribe to. The community includes an acceptance of all current scientific study to shape their theology and interpret Scripture. ${ }^{3}$

Cobb also accommodates what historical-critical scholars have determined concerning

Scripture. $^{4}$

Cobb's methodology begins with Christian experience. Christian experience must

be based in who God is and how God is demonstrated in Christ. From this perspective,

the New Testament (NT) particularly the life and teachings of Jesus, the writings of Paul,

${ }^{3}$ Cobb and Lull, Romans, 14. Others outside of Cobb's direct process community also recognize the scientific shift in new physics concerning the immanence of God, "Recent developments in physics have opened man's mind to the invisible aspect of matter and lead us into believing that what appears to the eye as physical and material is really non-material. Perhaps energy is the only ground of reality in the universe and not what is material. If energy is activity and the Holy Spirit is the activity of God, there may be an essential relationship between energy and the Spirit." Stephanou, "Divine Indwelling," 146.

${ }^{4}$ In his newest book relating to Jesus' Abba, Cobb explains in the preface the way in which he intends to interpret Scripture, which clearly matches that of the historical critical method. "To grasp Jesus' understanding requires that we make use of critical methods to distinguish Jesus's thought from the thought of others, especially those others who wrote about him. To do this we have to make judgments about the relative reliability for this strictly historical purpose of various writings. Biblical scholars have achieved considerable consensus on these questions. My intention is to build on that consensus. Our earliest written sources are the letters of Paul. In them we learn quite reliably of Paul's own experience and about what was happening in some of the early, predominantly gentile, churches. But Paul does not give us much direct information about Jesus' teaching — he did not know Jesus before his crucifixion. To learn more about Jesus' teaching, scholars turn to 'Q,' which stands for Quelle, the German word for "source," precisely because it is our best source for Jesus' sayings." John B. Cobb, Jesus' Abba: The God Who Has Not Failed (2016), xiv. 
and the fourth gospel have "recognized relevance" for all Christians. ${ }^{5}$ For Cobb, the problem with the NT is that it has all of the obstacles of the $1^{\text {st }}$ Century culture and history to sort through in order to get to pure Christian experience. Therefore, Cobb seeks out a method to get to the ideal Christian experience using the limited tools of theological scholarship and seeking a philosophical system which can help to provide the best consistency to hold the experience within a theological system. ${ }^{6}$

Cobb speaks of the primacy of experience in terms of the function of the Spirit. He suggests that the Spirit enlightens and frees us and therefore it is best to be responsive to that Spirit. For Cobb, Scripture must serve the Spirit while believers are still dependent upon the Scripture. ${ }^{7}$ While Cobb does not advocate for the entirety of either the biblical or Whiteheadian worldview, he believes the Whiteheadian hermeneutic is helpful for extracting current biblical interpretation out of the enlightenment paradigm and perhaps provides a less fragmented interpretation. Cobb looks to the NT for the data of Christian experience and relies on the system and language of process philosophy for the expression of theology, specifically the metaphysics of Whitehead. ${ }^{8}$ It could be said that

${ }^{5}$ John Cobb, "Theological Data and Method," The Journal of Religion 33, no. 3 (1953).219-220

${ }^{6}$ Cobb, "Theological Data and Method."

7 "The Holy Spirit enlightens, guides, directs, and lures. It makes thinking possible, but it embodies a wisdom and a truth that always exceed our rational powers. This is one reason that the separation of ends and means is so inappropriate. We cannot by reason, or by submitting to the authority of scripture or Holy Spirit, establish a purpose that then remains fixed while we go about implementing it without further reference to scripture or Holy Spirit. That would be to return to the letter and the law. On the contrary, the working of the Spirit is pervasive and never to be captured in a final statement. Our task is to learn, individually and collectively, to be open to the Spirit, responsive to it, freed and enlivened by it, and thus constantly led in appropriate ways beyond our understanding. The role of leaders in the church is to facilitate the working of the Holy Spirit... We must learn to use the scripture in the service of the Holy Spirit whose liberating work we can understand only in continual dependence upon scripture." John B. Cobb, Can Christ Become Good News Again? (St. Louis, MO: Chalice Press, 1991), 126-127.

${ }^{8}$ Bryan suggests that for Cobb, the normative authority for a Christian theologian is a "univocal" relationship between the Bible and philosophy offering them equal value. As a Christian, one needs the Bible, and as a theologian one needs philosophy. While the univocal equation of the Bible and philosophy 
Cobb's method is an experiential theology. It depends on empirical evidences gathered by the person's experience with the natural world and God, expressed through the process philosophy of Whitehead. ${ }^{9}$

The historical background in the first chapter of this dissertation expresses the comparison and contrast between the methods of Cobb and Wesley. Wesley's quadrilateral approach claims Scripture as the norming authority and includes the church's tradition, reason, and experience in a supporting role. Cobb's constructive speculative philosophy includes experience, reason, and Scripture, and Cobb has sought a way to express pure Christian experience from Scripture through Whiteheadian philosophy. Cobb, thereby places much significant emphasis on current interpretations of the community, but perhaps no more than substantialist usage of enlightenment philosophy or Wesley's use of classical philosophy. Historical context is used as a tool to pry out the pure experiential meaning of Scripture and re-apply it to current scientific and philosophical understandings. Cobb does not deny the Whiteheadian filter through which he looks at Scripture. He, instead, points out that the modern thinkers are doing the same

may be too strong for Cobb, he does seek to look for the data of Christian experience in the NT and use philosophy as the consistency to hold it together. Lawrence Dow Bryan, "The Understanding of Jesus Christ in the Theology of John B. Cobb, Jr.: A Study of the Position of Christology within a Christian Adaptation of Whiteheadian Organismic Philosophy" (Dissertation, Northwestern University, 1973), 12-15.

${ }^{9}$ Bryan is writing specifically on the doctrine of Christology in the theology of Cobb. Christology is directly tied to Cobb's understanding of indwelling. Bryan quoting Cobb: “'Constructive Christology is, in a broad sense, empirical. That is, it will assert nothing for which it cannot find grounds in experience. But it need not construe experience narrowly. Thoughts and feelings, hopes and fears, and mystical intuitions constitute experience as well as data of sense experience. Nothing is excluded except assertions made simply on authoritarian grounds. Constructive Christology cannot begin with the church's Christological dogma. Instead, it must look again, critically, at the evidence on the basis of which the church arrived at its conclusions." Bryan, "Jesus Christ in John Cobb", 16. For additional analysis of Cobb's theological method reference part I of Chul Ho Youn's dissertation. Youn, "God's Relation to the World". 
thing regarding their own enlightenment presuppositions. ${ }^{10}$

Cobb regularly admits that Whitehead is his main influential source for his system of theology. ${ }^{11}$ He directly ties this in with his views on indwelling in his commentary on Romans concerning the theme of mutual immanence listed in the introduction as well as in his chapter discussing Romans 6:1-8:39. ${ }^{12}$ Cobb develops the mutual immanence ideas of Whitehead to explain the Christological understanding of Jesus. He compares the primordial will described by Whitehead to the Greek Logos used in Scripture. According to Cobb, when an individual is open to the Logos of God they become the incarnation of the Logos, which is considered to be Christ. ${ }^{13}$ The man Jesus was the most open to the

${ }^{10}$ Cobb believes that the enlightenment scientific worldview which has proven to be incorrect and therefore the ecological option which Whitehead offers is better for the interpretation of Scripture than the dualistic modern option. "Some object that by giving so large a role in my thought to a model learned from a modem thinker I have subordinated the Bible to something alien. I do not agree. I know no one who does not think and interpret the Bible in terms of some notion about reality, consciously or not. Most, today, are deeply influenced by the Enlightenment model, even if - indeed, especially if - they have never thought much about it. This model is deeply antithetical to the biblical worldview and has seriously weakened our living relation to the Bible, whereas Whitehead's model is far more continuous and congenial...Of course, that vision is prescientific, and Whitehead's is not. I have no interest in defending all aspects of the biblical worldview — nor Whitehead's either, for that matter, But whereas the hermeneutic of the scholar of an Enlightenment discipline has required radical excision of the 'valid' biblical from the biblical worldview, a Whiteheadian hermeneutic allows for a less fragmented appropriation." Cobb, Good News, 46.

${ }^{11}$ Cobb, Structure, 149.

${ }^{12}$ Cobb and Lull, Romans. This will be further developed in Chapter 4 of this dissertation.

${ }^{13}$ Wheeler demonstrates the lack of differentiation between Christ and the Spirit in Process thought. "The immanence of God in Jesus as the Christ (= Logos in Cobb's Christ in a Pluralistic Age) and the immanence of the Holy Spirit in believers as the basis of sanctification and Christian unity are systematically differentiated in accordance with Trinitarian theology in traditional Christianity. In process thought there is no systemic reason for making this differentiation. 'Logos' and 'Spirit' would simply be two historically attested metaphors for describing divine immanence.” Griffin et al., eds., Searching for an Adequate God: a Dialogue Between Process and Free Will Theists, 123-124. Marjorie Suchocki explores the possibilities that the Holy Spirit may be the transformation of the Logos realized in the world. "Insofar as we instantiate that aim, the Spirit is born in us, becoming one with us in the creation of community. In other words, Christ offers creative transformation; the Spirit is creative transformation realized in the world. In this case, of course, the Spirit is not manifest as Spirit per se, but only in 'works of mercy,' or the unitive work of God with us in history." Suchocki, "Cobb's Trinity," 159. Cobb himself makes the connection of the Spirit with the Kingdom of Heaven. ". . .One step toward a solution would be to identify Spirit in its transcendent character as the resurrection of the dead or the Kingdom of Heaven. The justification is that the Spirit is regarded in Christianity as an eschatological phenomenon; it points to the End to which we move. That End is God as the resurrection or Kingdom. The immanent presence of the 
will of God in his life of any human; therefore he is called the Christ. For Cobb, Jesus is different from us in degree and kind in the sense that Jesus so closely identified with the Logos that Cobb says the Logos was a part of the personhood of Jesus. However, Cobb does not use Christ and Jesus synonymously. Other humans can also be the incarnation of the Logos by accepting this creative will in their lives and therefore be considered a form of Christ. $^{14}$

Cobb's methodology includes the use of Whitehead's hermeneutic regarding his interpretation of Scripture. ${ }^{15}$ Cobb places value on both philosophy and the NT. His theology of indwelling would be interpreted through current scientific ideas, as well as the philosophical system of Whitehead. Cobb's theological model for understanding the ontological nature of divine-human indwelling would, therefore, be derived from his theological method. His interpretation of Scripture, including Romans Chapters 6-8 addressed in Chapter 4 of this dissertation, will also be affected by his method.

With this brief discussion regarding Cobb's methodology it is now time to turn to the second step of this chapter. Through the comparison of the methodological categories of this dissertation, Cobb's understanding of the ontological nature of divine-human indwelling will be explored and proposed in the rest of this chapter.

Spirit now is anticipatory of that End, assuring us of it and uniting us with it. The Trinity can then be God, his Logos, and his Kingdom. The Logos is present with us as Christ; the Kingdom, as Spirit." Cobb, Pluralistic Age, 261-262.

${ }^{14}$ Cobb, Pluralistic Age, 140-142. Cobb, Good News, 102-103. Cobb continues to articulate a distinction between Jesus and the rest of creation because Jesus' incarnation of the Logos was unique in the connection with Jesus' personhood, but he does not see Christ and Jesus as identified with one another. Christ is much more inclusive than only the historical man Jesus. This will be explored more later in this chapter.

${ }^{15}$ Cobb, Good News, 46. 


\section{Ontology of God}

In this section of Chapter 3, Cobb's non-substantialist redefining of God will be presented and explored. Cobb's understanding of the ontology of God is largely related to his view of reality in general, which is compatible with the "new" understanding of physics. Cobb's attempt to integrate theology with energy based quantum physics leads to a reinterpretation of theology, largely dependent upon the philosophy of Alfred North Whitehead. Cobb rejects a substantialist reality and way of thinking. This leads him to redefine God based on this view of reality. First, a basic understanding of an experiential based view of reality and where God fits into that reality will be presented. Second, Cobb's doctrine of panentheism will be demonstrated. This includes the understanding of a di-polar God, the balance between transcendence and immanence, and God as an allinclusive standpoint. Third, Cobb presents the Trinity as a Trinity of natures rather than as Wesley's Trinity of persons. This will be examined in general and then in relation to the Logos as God's primordial nature and the Spirit as the possible consequent nature of God. Finally, three other concepts regarding the ontology of God include Cobb's engagement with the limited omniscience and non-omnipotence of God, and the temporal/historical nature of God.

\section{Experience-based Reality}

At a rudimentary level, Cobb's description of reality is a non-substantial process of occasions of experience. Cobb is hoping to help theologians move beyond the atomistic ideas of the modern enlightenment physics presented by Newton and Hume. There was a time when all of reality was understood as the combination of the smallest particles (atoms). Atoms were not only thought of as the smallest unit of reality, they 
were also understood to be static, without change. Therefore, as both the smallest particles themselves and the natural laws which determined their activity and connection to other atoms could be understood, then all of reality could be understood. This led to the compartmentalization of fields of study, as well as the methods of study. The isolation of an animal, for example, from its environment for the purpose of study was the best way to understand that species. Objective observation could be given to the study in the laboratory setting and dissection process, breaking it down into its smaller and smaller pieces. $^{16}$

Cobb, on the other hand, is moving away from this modern atomistic understanding of reality to a physical reality which is based on relational experience rather than substance. As modern scientists continued to break things down into their smaller and smaller pieces they came to understand that the atom was not the smallest particle after all. The nucleus of the atom was made up of protons and neutrons and those were made up of electrons. What was discovered regarding the nature of the smallest unit was two-fold: one, it was made up of energy and two, that it was constantly changing. There was no substantial static unit of reality of which all the rest of reality was built. Reality, therefore, must be reinterpreted as temporal in essence rather than substantial. If

16 "But the occurrence of one event grows out of the other events that make up its environment of its world. These other events are internal to it. Hence, the real things that make up the world are not separable from the environments. In a different environment, there would be a different event. The eventmodel is a relational model or an ecological one. Enlightenment science, shaped by the atomic model, makes the opposite assumption. To investigate scientifically is to remove a thing from its ordinary environment and examine it in an artificial one. Animals are put in laboratories in order to examine behavior under controlled conditions. There they are cut into pieces so that their behavior can be explained by the functioning of their organs and glands. No doubt, much has been learned by this reductionist method. But the Whiteheadian model would lead one to expect that an animal's behavior in a laboratory is quite different from its behavior in the world, and the organ's functioning when removed from the animal is quite different from its functioning $m$ the living body." Cobb, Good News, 45. 
there is a basic building block it would be one of energy rather than matter. ${ }^{17}$ Cobb calls these building blocks energy-events, yet he realizes the limits of this terminology. Substantialist thinking would still attempt to transform energy events into the basic spatial building blocks of reality. Energy-events are better thought of as relationaloccasions of experience. ${ }^{18}$

Modernists thought of the world as a collection of objects to be observed by human subjects. Cobb is unsatisfied with the subject and object terminology because it suggests a substantial object to be observed by a subject. ${ }^{19}$ If he has to choose, however,

17 "The electron can only be understood as a succession of events or happenings. These events can be viewed as transmissions of energy from past events to future ones. If we ask what they are in themselves, the only answer possible to the physicist is energy. The building blocks of the universe, the things of which everything else is composed, are energy-events." Cobb, God-World, 70.

${ }^{18}$ In my correspondence with Cobb he indicated that the use of energy events is too generalized and that he preferred the use of occasions of experience. He said that using the term energy event is like calling one's mother a bi-ped, while it may be true it is two basic of a description. "I suggest that you drop the term 'energy event' from the interpretation of my views. I do not reject the term, but its primary use is not in this place. A moment of human experience is in fact an energy event, but that is not what is most important about it for purposes of the topics you are discussing... With respect to 'energy events' every moment of experience embodies energy and is an event. So like the quanta and electrons, humans are made up of energy events. But the sort of energy event that constitutes my experience as I write you has so many characteristics lacking in electronic events, that calling is an energy event is a much more extreme reductionism than calling your mother a biped. She is that, but the occasions when that is an appropriate label are few and far between. It is only when thinkers threaten to end up in metaphysical dualism that we are likely to emphasize that everything that is an energy event or a collection of energy events." John B. Cobb, "Email Correspondance," ed. Cory Wetterlin (2014). In order to describe the basis of reality which Cobb describes in his work, it can still be valuable to use the energy-event terminology to describe the basic components. However, it is clear that Cobb sees this term as too basic for discussion human experience and I will therefore defer to occasions of experience rather than energy-events even when Cobb himself used energy-events in some of his older writings, such as "God-World".

19 "The quantum world is not much like the Cartesian one. It is more like a world of living subjects than a world of inanimate objects, but it is different from both. Scientists have largely given up understanding the quanta on the basis of their views of objects. There is talk of trying to understand the world of objects in terms of what has been learned of the quantum world, but progress is very slow. If scientists could recognize that the world of objects has never existed except as an abstraction, the prospects would be much better. One step in the right direction would be to give up the lingering substantialism that shapes the thinking of so many scientists. There is no evidence of any substance, subjective or objective. The only world that exists is a world of events. Events happen and then play a role in subsequent events. Are they "subjects" or "objects"? They are neither or both, since both terms point to aspects of reality but carry confused connotations derived from substantialist metaphysics." Cobb, Jesus' Abba, 87. 
he would describe reality as a vast community of subjects rather than a collection of objects. ${ }^{20}$ Each moment or occasion of experience has a subjective operation in the sense that it chooses to fuse with the previous occasion, thus creating a new subject/object which can then be fused with the upcoming occasion. ${ }^{21}$ Reality is then relational in essence, each subject relating to the next. This means that all things in the world are related to all other things in the world, although more particularly related to the more immediate occasions of experience within a particular process. Thus, removing an animal from its environment for observation is essentially changing that animal because the relating of occasions, which make up that animal and its environment has now changed. ${ }^{22}$ Cobb extends this relational understanding of reality to engage the question; How does God relate to all of these different occasions of experience? Cobb proposes that God perhaps is a unique type of occasion of experience which is a part of the vast reality and variety of experiential occasions. ${ }^{23}$ This however may be too limited for understanding

${ }^{20}$ Cobb, Jesus' Abba, 88.

${ }^{21}$ Cobb uses the illustration of one syllable in a word connecting to the next syllable in the word as an example of this experiential fusion. "In the case of two substances, they must be conceived as having their essential being first and then coming into relation subsequently. The relation is external to their being. But in the case of the two experiences, the second cannot come into being except as a process of reactualizing and completing the first. The syllable begun in the first moment demands completion in the second. The second momentary experience has no essential being that does not include the effective presence within it of the first. The presence of the first is constitutive of the second. The second embodies the first. In this very general sense every experience incarnates all the entities that it includes." Cobb, Pluralistic Age, 74. Cobb also uses the language of synthesis to express the fusion of one subject with another. Cobb, Jesus' Abba, 88.

${ }^{22}$ Cobb, Good News, 45.

${ }^{23}$ Cobb suggests in this quote that each variety of energy-event is a subjective nature from the electron energy event as well as the human and thus God as well. "The individual event is active, rather than simply passive; it is a subject rather than just an object. Just as there are specific differences between those energy-events [occasions of experience] we call electronic and those we call human, so there must be vast differences between human energy-events [occasions of experience] and the divine. But the problem posed by such differences is quite other than that which is generated when one supposes he has a more or less adequate notion of the physical and that whatever does not conform to that notion must be to that extent abstract. We now see that the physical in that sense is a secondary product of more fundamental 
God. Cobb therefore turns to Whitehead's di-polar view of God. ${ }^{24}$ God has both a physical pole and a mental pole. Some have suggested that the world is the physical pole of God. Cobb accepts this to a certain extent, but also recognizes its limitations. It tends once more towards a substantial understanding of reality, but in reality and in accordance with the Cobb's view of the biblical text, God is non-substantial spirit. ${ }^{25}$ Cobb uses the idea of different standpoints to try and explain the non-substantial view of God. God is an all-inclusive standpoint. This may seem difficult when one thinks of the physical pole as a standpoint, but when thinking of the mental pole there is no longer a need to think of part of God being everywhere. As Spirit, where ever any part of God is present, all of God is present. ${ }^{26}$ Cobb explains God's relation to the world in a panentheistic model. God is in all and all is in God and yet God is beyond all.

processes, and that when we identify these processes, we have arrived at the kind of reality which can include also what we usually call mental and spiritual phenomena. If what is most real are energy-events [occasions of experience], and if these are highly diverse in character, then God can be conceived as a very special kind of energy-event [occasion of experience]." Cobb, God-World, 71.

24 'In Whitehead's analysis this is because in every momentary occasion there is a 'mental pole' as well as a 'physical pole.' The physical pole is constituted by the inflowing of the many events of the past. The mental pole is constituted by an aim to build upon that past and to become what it is possible to be, given that past. This means that there are alternatives among which the occasion can choose and a call to realize the richest alternative. This requires of the occasion a decision. This supplementation of the past world that introduces transcendence or freedom into each new occasion involves the inflowing of another 'one.' Although it is one of the many, it is not simply that; for its contribution differs from the others. It contributes novelty, alternatives, freedom, and in human occasions, the dimension of morality and responsibility. Whitehead calls this 'God,' and I call the incarnation of God in each occasion, as one of the many that become one, 'Christ.'" John B. Cobb and Paul F. Knitter, Transforming Christianity and the World: A Way Beyond Absolutism and Relativism (Maryknoll, NY: Orbis Books, 1999), 157.

${ }^{25}$ Cobb brings in his interpretation of the biblical record as well in support of this: "The biblical vision is quite different. All creation is good in itself and for God. The image of the world as God's body vivifies the immediacy of the contribution each creature makes to God as well as suggesting how intimately all are bound up with one another. Still, God's body is not, as such, God. God is Spirit." Cobb, Good News, 183-184.

${ }^{26}$ Cobb, Natural Theology, 158. 


\section{Panentheism}

According to Cobb, the world is made up of relational occasions of experience.

God co-constitutionally relates to all of these experiential occasions. Therefore, God is in all of these occasions. Cobb compares Wesley's understanding of omnipresence, connected with omniscience, to the ontology in an experiential based cosmos. God relates to or participates in every subject. God is therefore present in every subject and every subject is present in him. ${ }^{27}$ The relational model of God and the world allows for, what Cobb calls, God's participation with every other type of occasion of experience in the cosmos. ${ }^{28}$ And yet God is beyond all, and this is where the mental pole comes in. Rather than divinization of the world, and thus eliminating God as a unique subject in the way that pantheism does, Cobb demonstrates God's personhood in that God has a will which is beyond the rest of the world. ${ }^{29}$ The mental pole of God is the creative lure, will, or aim for the world (this will be more fully developed later in relation to Cobb's Trinity of natures).

Cobb seeks to find a perspective between classical theism and pantheism. ${ }^{30}$

${ }^{27}$ Cobb, Grace and Responsibility, 54. This reasoning also provides the means for God's cosuffering with the world. As God knows and experiences everything and person in the cosmos, God knows and participates in that suffering. "A God who is affected by all that happens, suffering in all suffering and rejoicing in all rejoicing is very different from the impassive deity of an orthodoxy." John B. Cobb, Is It Too Late?: A Theology of Ecology (Beverly Hills, CA: Bruce, 1972), 133-134.

${ }^{28}$ Cobb, Good News, 45-46.

29 "I believe it offers us our best analogy for thinking of the spatial relation of God and the world. God's standpoint is all-inclusive, and so, in a sense, we are parts of God. But we are not parts of God in the sense that God is simply the sum total of the parts or that the parts are lacking in independence and selfdetermination. God and the creatures interact as separate entities, while God includes the standpoints of all of them in his omnispatial standpoint. In this sense God is everywhere, but he is not everything. The world does not exist outside God or apart from God, but the world is not God or simply part of God. The character of the world is influenced by God, but it is not determined by him, and the world in its turn contributes novelty and richness to the divine experience. The doctrine that I am developing here is a form of 'pan-en-theism.'" Cobb, God-World, 79-80.

30 "It is, in my understanding, a type of theism. But it differs from much traditional theism insofar 
Classical theism presents a substantial view of reality in which God is separate from and over against the rest of the cosmos. Pantheism however eliminates the personhood of God and simply makes all of reality divine. Cobb's panentheism moves away from substantial reality, thereby allowing God to be involved with all of reality in process. Yet God is not fully absorbed into the cosmos because God also has a mental pole or divine will which transcends the physical. ${ }^{31}$

God, through his persuasive will, enables every part of the cosmos to enter into the creative process with God. ${ }^{32}$ Each subject in reality can choose to follow the persuasive will of God and continue to emerge more and more incarnated by the will of God. Cobb calls this incarnation of the will of God, or the Logos, within each subject of reality, Christ. ${ }^{33}$ All of reality is therefore in Christ and Christ is in all. This "radical" incarnation is Cobb's balance between the transcendence and the immanence of God. God's will is transcendent of the cosmos and yet, as it is accepted by the things and people of the world, it becomes fully incarnate within the world. ${ }^{34}$ For Cobb, the

as the latter stressed the mutual externality of God and the world, with God conceived as occupying another supernatural, sphere. It differs from pantheism when pantheism is understood to be the identification of God and the world. The doctrine that I am developing here is a form of 'en-theism.' Yet, in reality, panentheism is the synthesis of the central concerns of traditional theism and pantheism, and it distinguishes itself from both only in ways that are secondary." Cobb, God-World, 79-80.

${ }^{31}$ Cobb, God-World, 77, 79-80. Also see previous footnote on the di-polar nature of God.

32 "Rightly understood, our participation in creative activity does not place us in competition with God. God does not create as one being alongside other beings. The image of a huge person outside the universe and creating it as a human being makes a toy simply cannot work. God is creatively present everywhere, acting in and through all things. Human freedom, human imagination, human creativity, are all aspects of God's creative working. God creates in and through all the other creatures of the earth as well." Cobb, Good News, 183.

${ }^{33}$ Cobb, Good News, 85 .

34 "This means that when we think of God as directivity we think of incarnation. God transcends the world as the giver of all new possibility. It is because of God that what-is-not yet can come into being. It is by becoming present or incarnate as their directivity that God renders the appropriate what is-not-yet effective as an aim or lure, energizing and directing the activity of each thing and person. In this way God, 
acceptance of the persuasive will of God is what it means to believe in God. The results

of the creative will of God, transforming reality, is the evidence for God's existence. ${ }^{35}$

Cobb has intentionally developed a pan-en-theistic theology of God to bridge

classical theology's more distant view of God and pantheism's cosmic absorption of the divine. How might Cobb express the Trinity within this kind of panentheistic divine ontology?

\section{Trinity of Natures}

The will of God has already been mentioned as the mental pole of God. It is time to go more deeply into this subject of God's will or nature. In Cobb the nature of God can be described in two different ways: the primordial will of God and the consequent nature of God. If there is an understanding of the Trinity in Cobb's theology it may be found in this trinity of natures. As a point of comparison, the Trinity is significant because Wesley has a very strong Trinitarian understanding of God. First, this will be taken up by a look at Cobb's descriptions of the Trinity as he describes it. Secondly, this will be addressed through analysis and reinterpretation of Cobb's Trinity by Marjorie Suchocki, whom Cobb has affirmed and is in agreement with.

Cobb interprets his theology of the Trinity through the lens of Whitehead's

as the source of unrealized possibility, inexhaustibly transcends the world, but it is precisely as transcendent that God is immanent in the directivity that moves in and through all living things. Thus God as Creator is not only transcendent but also fully and radically incarnate." John B. Cobb, Theology and Pastoral Care (Philadelphia: Fortress Press, 1977), 49.

35 "The creative action of God which concerns us is the creation that takes place now, moment by moment, in our environment and in ourselves. In each moment God confronts the totality of the past with new possibilities. How the world responds, whether in acceptance or rejection of these possibilities, God does not determine. He creates by persuasion in and through the free decisions of his creatures. To believe in God is to trust his creative work amongst and within us, to adapt ourselves to it--to attend to it as it operates in all creatures, to sensitize ourselves to it as it works in us, and to respond to its call to new risks." Cobb, Is it too late?, 136. 
process philosophy. Whitehead suggests that there is both a primordial nature of God and a consequent nature of God. ${ }^{36}$ This is the basis of how the Trinity might be defined in Cobb's theology: God in general, the primordial will as the logos, and the consequential nature (potentially as spirit), specifically in relation to the fourth phase of Whitehead's cosmic process. Cobb admits he may be stretching the ideas of Whitehead in some respects. The fourth phase is the possible passing of the consequential nature of God back into the temporal world for the "immediate fact of relevant experience." 37

Cobb is clear that the doctrine of the Trinity needs to be redefined. He does not accept the Eastern view of three persons, the Agustinian view of emanation, the nonmetaphysical trinity, nor the economic trinity for various articulated reasons. ${ }^{38} \mathrm{Cobb}$ considered that the Trinity may be an artificial game which must ultimately be united in the understanding of divine love. Christ/Logos as the creative side of love and the Spirit as the responsive side of love. ${ }^{39}$

Cobb is not definitive in his conclusions regarding the Trinity. He suggests that his doctrine of the Trinity is still very much in a process of development regarding both Christ and the Spirit in Christ and the Pluraistic Age. He was willing to reimagine the Trinity in a collective project entitled Trinity in Process, where Cobb starts the

${ }^{36}$ Cobb, God-World, 84.

${ }^{37}$ Cobb, Pluralistic Age, 14.

${ }^{38}$ John B. Cobb, Jr., "The Revitalization of the Trinity," in Trinity in Process: A Relational Theology of God, ed. Joseph A. Bracken, and Marjorie Suchocki(Continuum International Publishing Group, 1997), 20-22.

${ }^{39}$ Cobb and Slettom, Process Perspective FAQ. 
conversation. ${ }^{40}$ Cobb believes, the threeness of the Trinity is not a biblical absolutization. The basic binity of God's transcendence and immanence could be enough for understanding God in this way, but the distinctives within God could also be expressed as a quadrinity according the Cobb's reading of the Bible by including wisdom as a potential fourth element. Cobb's primary concern for the doctrine of the Trinity is for "the possible organizing of our thoughts about God corresponding to real distinctives within God." ${ }^{41}$

Cobb makes the following statement regarding the Trinity in Christ in a Pluralistic Age as follows: "the Trinity can then be God, his Logos, and his Kingdom. The Logos is present with us as Christ; the Kingdom, as Spirit." ${ }^{42}$ Cobb then points back to both Whitehead and Pannenberg proclaiming God as kingdom. For Cobb, the Logos is Christ, which is Jesus only in the sense of incarnation. He believes that identifying the Spirit as the transcendent resurrection/kingdom would be a good step forward by considering the Spirit as eschatological. ${ }^{43}$

Cobb understands the Spirit as the immanence of God in terms of the way in which the primordial will is both transcendent and immanent. He suggests that the distinction could be possible as the physical feelings of God from the physical pole through the consequential nature of God flooding back into the world. ${ }^{44}$ Just as a person

${ }^{40}$ Cobb, Pluralistic Age, 263. Cobb, "The Revitalization of the Trinity," 22.

${ }^{41}$ Cobb, "The Revitalization of the Trinity," 20-22.

${ }^{42}$ Cobb, Pluralistic Age, 261-262.

${ }^{43}$ Cobb, Pluralistic Age, 261-262.

${ }^{44}$ Cobb, "The Revitalization of the Trinity," 18. Wheeler, in his analysis of Cobb and process thought regarding the Trinity, is suspicious of the distinction between Logos and Spirit in process thought: "In process thought there is no systemic reason for making this differentiation. 'Logos' and 'Spirit' would 
is able to prehend the primordial lure of God presenting them with the creative

possibilities, so a person might have the possibility of prehending the consequential will.

Cobb uses the example of paranormal events like someone getting a premonition of a

landslide about to take place and thus slowing their car or being concerned for a person at a distance before actually know what is wrong as possible examples of a person getting a glimpse of the consequential will. ${ }^{45}$

Cobb sees this distinct element of God demonstrated in the Bible and the experience of the Christian community in the phenomena of spiritual gifts. These gifts seem to be paranormal or "somewhat discontinuous with the universal, transformative working of God in the world... ${ }^{46}$ Cobb suggests that Whitehead's previously described fourth phase in the cosmic process might be able to help account for this actual phenomena.

In Cobb's more recent books, he points to the lack of personal distinction between Christ and the Spirit. Cobb even claims that Paul never actually distinguishes Christ from the Spirit. ${ }^{47}$ The Trinity in Cobb's latest book is still based on Christ and the Spirit both flowing from Jesus' Abba to be incarnated in Jesus. ${ }^{48}$ Cobb sees the proclamation of both

simply be two historically attested metaphors for describing divine immanence." Griffin et al., eds., Searching for an Adequate God: a Dialogue Between Process and Free Will Theists, 123-124.

${ }^{45}$ Cobb, "The Revitalization of the Trinity," 17.

${ }^{46}$ Cobb, "The Revitalization of the Trinity," 13.

47 "And clearest testimony to this is in Paul. A fundamental characteristic of his congregations was the experience of the Spirit. This could be thought of as the Spirit of God, but Paul never separated it from Jesus. The God of whom he speaks is emphatically the Abba of Jesus. When he speaks of the Spirit of God, Jesus is already implied. Sometimes he speaks of the Spirit of the Son. Elsewhere he explicitly identifies the Spirit with the Lord, who is certainly the resurrected Jesus." Cobb, Jesus' Abba, 32.

48 “According to official teaching, only one person was incarnate in Jesus. To me, now, perhaps in too impatient a reaction to my earlier too slavish adoption of this restriction, the restriction itself seems ad hoc and undesirable. Is not God's Spirit incarnate in Jesus as much as God's Word? What is gained by 
the NT and the OT of the Spirit as the Lord, identifying the Spirit with Christ. Placing one's hope in the Spirit is the same as placing one's hope in the Lord because the Holy Spirit is God. ${ }^{49}$ Cobb interprets the traditional western understanding of the Spirit flowing from both the Father and the Son as the Spirit being no less incarnate in Jesus than was the Logos.

A reframing of Cobb's understanding of the Trinity can be found in the thought of Marjorie Suchocki. There are several reasons for including Suchocki's development of this doctrine and why it is significant in understanding the Trinity for Cobb. First, Suchocki wrote an article on Cobb's understanding of the Trinity. Second, the process community is very much a community of thought and Cobb regularly engages with those other writers who are Whiteheadians, believing in the importance of the process of discussion. ${ }^{50}$ Third, at a recent conference Cobb himself acknowledged Suchocki's work as significant concerning his understanding of the Trinity. ${ }^{51}$

Marjorie Suchocki follows along the same lines as described by Cobb himself. The initial aim and the consequential nature, or kingdom/peace of God, are what make up the Trinity. ${ }^{52}$ Process theology itself has moved toward the modes of being within God.

denying this? In the context of the early church's debates, some justification - at least some explanationcan be found, but today such distinctions complicate, and too easily distort (as in my own case), Christological thinking. In Jesus we find incarnate not only the creative, directive, and redemptive activity of God, but God's suffering love as well." Cobb, Good News, 48-49.

${ }^{49}$ Cobb, Jesus' Abba, 32; John B. Cobb, Sustainability: Economics, Ecology, and Justice. (Maryknoll, NY: Orbis, 1992), 130.

${ }^{50} \mathrm{Cobb}$ also at times will join his views with other process thinkers as a collective we, as demonstrated in his commentary on Romans. Cobb and Lull, Romans, 14; Cobb, "The Revitalization of the Trinity."

${ }^{51}$ Cobb spoke at the San Diego American Academy of Religion Meetings in 2015 regarding this.

${ }^{52}$ Suchocki, "Cobb's Trinity," 159. 
She confirms the language of modalism and an economic Trinity within the discussion. ${ }^{53}$ Suchocki, however, offers what she calls a revision of Cobb's understanding. She develops a dialectic between the expressions of Christ and the Spirit within the economic Trinity. Through this dialectic she identifies Christ with the primordial aim and the Spirit as the "incarnation of God's manifold peace in the world." 54 The world which has responded to the creative aim and is, therefore, incarnated actually becomes the Spirit of God. The world completes the being of God when it has been transformed by God's creative will. ${ }^{55}$ One might say it is the panentheistic nature of process theology itself that facilitates the community within God.

Cobb's understanding of the Trinity then, both by his own description and his acceptance of Suchocki's work, is such as he proposed many years ago: God is primordial/creative nature, and his consequent nature is the kingdom realized in the redemptive transformation of the cosmos. Cobb, as the panentheistic representative of this dissertation, has presented a non-personal version of the Trinity, in contrast to the three persons of the classical theist, like Wesley. Cobb and Suchocki have presented a Trinity of divine purpose and natures. The very nature of Cobb's Trinity begins to show the ontological nature of divine-human indwelling. If the Spirit is the consequent nature realized within the transformed world, which makes perfect the being of God, then this is the realized indwelling of the divine within all creation, let alone humanity. Now that

${ }^{53}$ Suchocki, "Cobb's Trinity," 161.

${ }^{54}$ Suchocki, "Cobb's Trinity," 161.

55 "God generates purposes for the world which are themselves the potentiality of Spirit. Insofar as the world incarnates these purposes. Spirit is born in the world, and therefore received into the divine character, everlastingly completing the divine being through the redemption of the world." Suchocki, "Cobb's Trinity," 162-163. 
Cobb's general understanding of the Trinity has been presented, a more in depth look at the primordial will (Logos) and the consequent nature (Spirit) can be developed.

\section{God as Lure - Primordial Nature (Logos)}

In Cobb's panentheistic model, he recognizes what traditional Christianity called the logos or the organizing principle as Whitehead's transcendent source of the aim. Cobb himself adapts this concept of the transcendent logos which expresses itself through the immanent incarnation of the creature ${ }^{56}$ In the discussion of Cobb's Trinity, this creative lure, the Logos, has been possibly identified as the son or Christ part of the Trinity. Cobb however differentiates between the Logos and Christ. The Logos is the transcendent unrealized creative lure of God, while Christ is the accepted incarnate Logos co-constituting the panentheistic cosmos of creation. ${ }^{57}$ This is particularly true for human beings as they have particular freedom to accept the creative aim and thus creative transformation of the Logos in their lives, thus becoming incarnated with the immanent Christ. ${ }^{58}$

For Cobb, this creative transformation is literally the life of the world. If the world

56 "In Christian tradition, the transcendent reality that in its incarnate form is named Christ is called the Logos. Christ is the Logos as incarnate. The Logos is the cosmic principle of order, the ground of meaning, and the source of purpose. Whitehead called this transcendent source of the aim at the new the principle of concretion, the principle of limitation, the organ of novelty, the lure for feeling, the eternal urge of desire, the divine, and God in his Primordial Nature.... It is this inclusive meaning of Logos, pointing to that which transcends humanity but expresses itself through creatures, which is adopted in this book. The Logos in its transcendence is timeless and infinite, but in its incarnation or immanence it is always a specific force for just that creative transformation which is possible and optimal in each situation." Cobb, Pluralistic Age, 71 .

${ }^{57}$ Cobb, Pluralistic Age, 71. This idea is briefly discussed by Lewis and Demarest, "In the Whiteheadian scheme, broadly speaking, the incarnation represents the immanence of the Logos in the man Jesus. John B. Cobb. Jr. argues that the substantialist model of the incarnation must give way to an experiential relation in which societies of past experiences or events merge in creative synthesis. The incarnation." Lewis and Demarest, Integrative Theology, 257.

${ }^{58}$ Cobb, Pastoral Care, 49-51; Cobb, Pluralistic Age, 76. 
is not growing, then it is dying. The only way for it to truly grow is by accepting the creative transformation that the Logos is offering as the future reality of the world. ${ }^{59}$ God is the lure to the new occasion, the one who calls creation forward from what it is to what it might become. ${ }^{60}$ This primordial nature of God is the novelty which is needed to bring the world out of its repetitive pattern. ${ }^{61}$ Cobb is careful to clarify, however, that this is not just a random novelty but an organized principle by which God seeks to persuade all of creation to become something different, better, or higher. However, the Logos is forever a principle of changing transformation rather than natural law imposed as static order. ${ }^{62}$ Cobb calls Logos the "fundamental impulse towards actualization." This impulse may be resisted and fought against by the inertia of past experience seeking to stay the

59 "Indeed, life itself is the continuing expression of the Logos as creative transformation. When creative transformation ceases, the organism dies and its body decays. There can only be advance into novelty or else erosion of what has been attained. In concluding this section, we must restate succinctly the identity and difference of Christ and Logos. The Logos is an eternal aspect of deity transcending every actual world as the Principle of possibility and of the relevance of that possibility. But the Logos is at the same time immanent or incarnate in the world. Only as incarnate does it exercise any effect. As incarnate, its effect is decisive. In Whitehead's words, 'The world lives by its incarnation of God.' God or the Logos as incarnate is Christ." (Emphasis added) Cobb, Pluralistic Age, 77.

60 "The total reality out of which each human occasion arises includes not only the adjacent events in the brain and the past human experiences but also God. Like other events, God influences the becoming occasion by being what he is. He entertains a purpose for the new occasion, differing from that entertained by the previous human experience. He seeks to lure the new occasion beyond the mere repetition of past purposes and past feelings or new combinations among them. God is thus at once the source of novelty and the lure to finer and richer actualizations embodying that novelty. Thus God is the One Who Calls us beyond all that we have become to what we might be." Cobb, God-World, 82.

${ }^{61}$ Cobb, Pluralistic Age, 76.

62 "The Logos is, therefore, not simply the sum of random purposes, anticipations, and novelties of experience. It is the ordered givenness of relevant potentiality. Ultimately it is the transcendent ordering from which derive the novel order and the ordered novelty in the world. Whereas this shows that the Logos is a transcendent ground of order, it leaves open the question of a second principle of order, a competing Logos. The Logos as described is the order of unrealized potentiality making possible by its immanence the realization of novel order. But there is also an order in the past, given world. What is the status or principle of this order, the order that science investigates? Against the view of natural law as imposed, static order, we can see today that the order in the given world is statistically descriptive of its dominant patterns and tendencies." (Emphasis added). Cobb, Pluralistic Age, 75. 
same. The Logos is threatening to any world, because it calls for the transformation of that world. The Logos introduces the tension between the now and the not yet. ${ }^{63}$

Once again referencing Whitehead, Cobb wrote, "Whitehead called this transcendent source of the aim...the principle of concretion, the principle of limitation, the organ of novelty, the lure for feeling, the eternal urge of desire, the divine, and God in his Primordial Nature." 64 God is the call forward for creative transformation. Once this transcendent creative call is accepted by responsive love it then becomes the immanence of God co-constituting that part of the world which has accepted it. ${ }^{65}$ This acceptance Cobb calls incarnation and thus Christ.

The Logos is always present within all of creation to a different degree and even a different kind, depending on the acceptance of that part of creation. ${ }^{66}$ For Cobb then, Jesus is a unique event or occasion of a person accepting the Logos so openly that Christ can be identified with the self of the historic Jesus. ${ }^{67}$ This is what it means for Jesus to be called the word or Logos made flesh. ${ }^{68}$ Cobb points out the temptations of Jesus as the

\footnotetext{
${ }^{63}$ Cobb, Pluralistic Age, 76.
}

${ }^{64}$ Cobb, Pluralistic Age, 71.

65 "To love in this sense is to constitute ourselves in each moment in relation to the future of the other as well as to our own future. Christians know, in naming the Logos "Christ," that the divine has constituted itself toward the world once and for all as love." Cobb, Pluralistic Age, 142.

${ }^{66}$ Cobb, Pluralistic Age, 142.

${ }^{67}$ Cobb and Knitter, Transforming Christianity, 158. Cobb believes that Christ has been too removed from the historic Jesus. While he does not agree with what he sees as the later writings of the NT (specifically the Gospel of John) encouraging the bodily resurrection of Jesus and encouraging the divinity of Christ, he does want to recognize that is was in Jesus that the transformative work of incarnate Christ is most "vividly manifest." Cobb, Good News, 102-103.

${ }^{68}$ Cobb, Pluralistic Age, 72. 
struggle of the "I" of Jesus with the Logos. ${ }^{69}$ But for Cobb, the historical self of Jesus

was so identified with the Logos that he was co-constituted and incarnated by the Logos, so much so to be a different kind of Christ than the rest of creation, not simply an incarnation of greater degree. Cobb states that Jesus was the paradigm of the incarnation of the Logos, therefore, Jesus was Christ. ${ }^{70}$

Cobb, however, does not use Jesus and Christ synonymously. ${ }^{71}$ While Jesus was Christ, Christ is broader than Jesus. The creative aim of God can be accepted by any person, occasion, or event in creation. The incarnation of Christ can therefore be present in all things. All of Christian history is a recognition of the transformative Logos incarnated in that history therefore calling it Christian. ${ }^{72}$ For Cobb, Logos is love itself but it is not Christian unless it is co-constitutive of existence. ${ }^{73}$ For this reason, Jesus is

69 "The stories of his temptation in the wilderness, his struggle in Gethsemane, and his forsakenness on the cross are not historically reliable, but they witness to the belief on the part of his disciples that he was not continuously free from the tension between his 'I' and the Logos. To affirm today that he was fully human entails this same assumption. But our attention is directed also and primarily to the new thing that occurred in him. That new thing was the full incarnation of the Logos." Cobb, Pluralistic Age, 142 .

70 "The distinctiveness of Jesus can be spoken of in terms of Christ. Christ is the incarnate Logos. As such Christ is present in all things. The degree and the kind of Christ's presence varies. The fullest form of that presence is that in which he co-constitutes with the personal past the very selfhood of a person. That would be the paradigm of incarnation. In that case Christ would not simply be present in a person but would be that person. The distinctive structure of Jesus' existence was characterized by personal identity with the immanent Logos. Hence it is a matter of literal truth to affirm the identity of Jesus with Christ. In all things Christ is present. Jesus was Christ." Cobb, Pluralistic Age, 142.

${ }^{71}$ Cobb, Good News, 102-103.

${ }^{72}$ Cobb suggests that seeing history as Christian history is a matter of perception of awareness of the incarnate Logos within the history of the world, once again reminding the reader of a process reality constituted of energy-events. "Yet 'Christ' is not a figment of imagination. 'Christ' points to a reality that exists whether we recognize it or not, but it points to this reality as experienced and known in Christian history. The reality known in Christian history is recognized as present, if unacknowledged, everywhere. For the Christian, Christ is visible also where he is denied. Creative transformation is discoverable in nature, in history, and in personal experience. In this sense Christ is fully immanent." Cobb, Pluralistic Age, 80-81.

73 "Not only is the Logos itself love but the creative transformation which is its work in us is human love. That also is not immediately apparent; for love as creative transformation is not emotion, or 
the determinant of the meaning of love for Christians. ${ }^{74}$ Both in word and deed Jesus lived as the incarnated Logos. For Cobb, "The understanding of Jesus that emerges from these arguments is of a man so empowered and indwelt by the Logos that his words and deeds give unqualified expression to God's purposes." ${ }^{, 75}$

Jesus' teaching brings the tension of the Logos to each person who hears it with the potential to accept the creative transformation within their own lives. The hearer thus becoming Christ, or as Cobb recognizes Paul's favored expression, in Christ. ${ }^{76}$ Christ can be present within the church both through Logos and Jesus. Jesus draws people to be open to the Logos by his teaching. ${ }^{77}$ For Cobb, the Eucharist can also play a role in this. This chapter will return to the Eucharist later in the section on Cobb's understanding of the ontological nature of divine-human indwelling.

Once again, as in the discussion of the Trinity in general, Suchocki acknowledges that Cobb identifies Christ with God's incarnate initial aim. She then proposes that the process community would "speak of God's creatively transforming word" sufficiently to “name Cobb's 'Christ' or principle of creative transformation."78

The panentheistic nature of Cobb's interpretation of the ontology of God shines through once again in his reinterpretation of the role of Christ in the Trinity. All of the

sentiment, or moral virtue. It is a way in which the process of becoming is formed or structured. But this ontological character of love is not strange to the Christian; for Christian love has never been an expendable addition to an already formed being." Cobb, Pluralistic Age, 142.

${ }^{74}$ Cobb, Pluralistic Age, 85 .

${ }^{75}$ Cobb, Pluralistic Age, 129.

${ }^{76}$ Cobb, Good News, 118.

${ }^{77}$ Cobb, Good News, 117.

${ }^{78}$ Suchocki, "Cobb's Trinity," 158. 
cosmos is included as potential for the incarnated Christ. In the face of the claim that all of creation is incarnated in Christ, at least to a certain degree, and as each person or thing accepts God's transformative purpose for it, it will become a clearer representative of that incarnated Christ. While Cobb does acknowledge the uniqueness of Jesus both in degree and kind as the Christ, this uniqueness is not pre-existent or divine in the same way traditional theism would claim. To be Christ in classical theology simply means to be an anointed one. Jesus was unique, not so much because he was an anointed one, but because he was divine. Cobb is not so concerned with the divinity of Jesus, he in fact downplays the "proofs" of divinity presented in the NT, especially within the Gospel of John. $^{79}$

This study will now turn to the remaining aspects of the nature of Cobb's Trinity, the consequent nature of God also referred to as the Spirit, the kingdom, and the peace of God.

\section{Consequent Nature - Peace (Spirit)}

There seems to be two ways in which Cobb refers to the Holy Spirit in his writings. The first could be confused with the way that he speaks of Logos as the aim, lure, or enlivening will of God. The second is in a more differentiated way or manner from the Logos. The Logos is the primordial nature or the initial aim and the Spirit or Kingdom is the consequent nature or the fulfillment of the Logos. This of course can get confused with Cobb's understanding of Christ as the immanent incarnation of the Logos.

Here, the latter meaning of the Spirit, as the consequent nature flooding back into

\footnotetext{
${ }^{79}$ Cobb, Jesus' Abba, 24-27.
} 
the world, will be dealt with first. The Spirit as consequent nature seems to be the more defined interpretation of the Spirit, especially in relation to Cobb's understanding of Trinity. Cobb closely follows Whitehead in this understanding of the Spirit as the peace or Kingdom. Cobb describes Whitehead's view of peace as a "positive feeling that crowns the life and motion of the soul." 80 For Whitehead this peace has very little to do with hope for the future or interest in the present. It is rather a "broadening feeling due to emergence of some deep metaphysical insight." ${ }^{81}$ It surpasses personality, it is a grasp of infinitude, and an appeal beyond boundaries. ${ }^{82}$ Cobb suggests that Whitehead's consequent nature could very well be understood as the Spirit. ${ }^{83}$

Cobb suggests that the Spirit is analogous to Christ, it is both transcendent and immanent. He suggests that a possible step forward in understanding the Spirit would be "the transcendent character as the resurrection of the dead or the Kingdom of Heaven." 84 The Spirit is looked at as an eschatological something that is realized at the end, thus possibly identified with the Kingdom. Cobb, however gives a careful definition to the Kingdom. He prefers to understand the kingdom as a realm or a commonwealth. ${ }^{85}$ There are several reasons for this. The first is to remove the connotation of force from God towards the world, rather than a persuasive love for the participants to respond to.

${ }^{80}$ Cobb, God-World, 85-86.

${ }^{81}$ Cobb, God-World, 85-86.

${ }^{82}$ Cobb, God-World, 85-86.

${ }^{83}$ Cobb, Pluralistic Age, 261-262.

${ }^{84}$ Cobb, Pluralistic Age, 261-262.

${ }^{85}$ Cobb, Jesus' Abba, 2; John B. Cobb, Reclaiming the Church, 1st ed. (Louisville, KY: Westminster J. Knox Press, 1997), 68-70. 
Second, Cobb for a long while wanted to be particularly sensitive and sympathetic to the feminist theology and the word kingdom is patriarchal. ${ }^{86}$ More recently, in his latest book, where Cobb recognizes the value of God as Jesus' Abba, despite the possible offense to feminism, he wants to convey the commonwealth or household of the heavenly father. ${ }^{87}$ Once again Cobb removes the forceful character of God as law-maker or judge and emphasizes instead the compassionate Abba.

The first meaning of Spirit for Cobb is a more general reference to God in interaction with the world. As one might say that a person has a human spirit so God has a Holy Spirit. So when Cobb references the Holy Spirit he is often referring to God in general. Cobb's later writings turn towards a focus on the ecological problem that the world is facing. Cobb recognizes that belief in the Spirit is the only source of hope that he experiences. He then clarifies by stating that the Spirit to which he if referring is, of course, God. ${ }^{88}$

Within this more general meaning of the Spirit, Cobb attributes the same things which he has attributed to God in general and to the Logos as the initial aim. The Spirit is the lure which gives freedom and the potentiality of all to follow God's creative will. ${ }^{89}$ Cobb emphasizes that the Spirit is not an external force, like the potter on the clay, but

\footnotetext{
${ }^{86}$ Cobb, Reclaiming, 68-70.

${ }^{87}$ Cobb, Jesus' Abba, 2.

${ }^{88} \mathrm{Cobb}$, Is it too late?, 144.

89 "Process theologians name the source of these possibilities "God." We acknowledge in the most literal and straightforward sense that not only freedom but life itself is the continually renewed gift of God. God, as the one who enters into our very being or experience moment by moment to free and enliven us, is quite properly called the Holy Spirit." Cobb, Good News, 126-127.
} 
rather it "works within other powers to empower, enliven, and direct."

Cobb pushes away from the personal Spirit interacting with the personal human spirit, used by the church to maintain and exercise power over and against the human spirit. Cobb, instead, points to a more primitive and intimate understanding of two spirits responding to one another. ${ }^{91}$ Once again this would be God as Spirit panentheistically enlivening any human spirit.

Cobb's panentheism comes through even stronger as he speaks of the Spirit pervading the cosmos. The Spirit relates to everything everywhere and can be found in the cells of our bodies, our minds, and our spirits. ${ }^{92}$ Bringing in OT language, Cobb relates the Spirit to the Wisdom throughout the cosmos that "transcends any human understanding." ${ }^{93}$ This same Wisdom is also at work in our bodies, according to Cobb. He does recognize the climax of this Wisdom, just as the clearest understanding of the incarnated Christ, is embodied in Jesus. ${ }^{94}$

Whether Cobb's theology of the Spirit is spoken of in regards to the more technical consequent nature tied to his philosophical mentor Whitehead, or as the more general Holy Spirit which is God, Cobb's panentheism shines through. The consequent nature is something that can be realized within all of creation and the other is spoken of as an all-pervasive Spirit throughout the cosmos. Both of these meanings have much to

\footnotetext{
${ }^{90}$ Cobb, "Wholeness," 242.

${ }^{91}$ Cobb, Structure, 118.

${ }^{92}$ Cobb, Reclaiming, 101-102.

${ }^{93}$ Cobb, Reclaiming, 101-102.

${ }^{94}$ Cobb, Reclaiming, 102-103.
} 
do with the ontological nature of divine-human indwelling and will be more definitively expressed in the third section of this chapter.

\section{God's Liberating Power}

One of the striking differences between classical theism's ontology of God and that of Cobb as a process theologian is the historical nature of God and the way in which this historical nature affects the interpretation of God's power. For classical theism, God is removed from time and space and, therefore, all of his power is based on predetermined actions which are willed by God outside of the realm of time and space. God's power then, for classical theism, is complete, sovereign, unchanging, and omnipotent.

Cobb, however, believes that God is historical. God has a history and God's history is involved with both divine and human actions within history. ${ }^{95}$ This has some significant interpretative effects on the power of God. Cobb strongly argues against any sort of omnipotence in God's ontology. Cobb suggests that logically any belief in omnipotence would insinuate a pantheistic view of God. For God to be all powerful means that he is acting upon all which is within his power, thus he is acting upon himself, leading to pantheism. ${ }^{96}$ For Cobb, God's power is directly connected to the relational

95 "Particularly striking is that God has a history. This is time in several senses. First, God is involved in the human stories, shaping and directing them. God's actions at one time depend on previous divine actions and human responses. Expectations of God's further actions based on past actions shape present human actions. Second, the understanding of God changed, so that the ways God acted and the divine purposes have a different character at different times. Third, throughout, God's chief concerns relate to what is happening historically. God is interested in individuals, but usually this interest has to do with their historical roles." Cobb, Jesus' Abba, 132.

96 "Power over what is wholly powerless is not power at all. By attempting to exalt God's power into omnipotence, that is, all power, they denied that God's power could be exercised on anything other than God's own power; in this way they emptied the notion of power of all meaning. Omnipotence in this sense can be attributed only to the whole or to the being of the whole. Omnipotence leads logically either to pantheism or to the identification of God with what Eckhart knew as Godhead." David Tracy and John B. 
character of God. He describes God's power as persuasive rather than coercive, following Whitehead once again. ${ }^{97}$ God does not coerce creation and force it to his will, but rather God is the creative, liberating lure for all of creation to become what is in accordance with God's creative will, thus becoming his consequent nature.

Cobb even moves away from the language of persuasion to empowering or liberation power. ${ }^{98} \mathrm{He}$ believes that the power of God is based upon educating individuals in such a way as to broaden their understanding of the different choices that are available to them. The individual can then make their own free choice, whether this is according to God's will or against it. This liberating view of God's power includes the possibility and reality that God can and does fail..$^{99}$ God's will and intentions are not always accepted, therefore God can fail. This is an essential point for process theology in the engagement of God's relationship to evil within the world. God is not all powerful, his persuasive power is set against the power of choice which he has given to all creation. Therefore,

Cobb, Talking About God: Doing Theology in the Context of Modern Pluralism (New York: Seabury Press, 1983), 66.

${ }^{97}$ Cobb, Jesus' Abba, xix.

98 'There are, however, other ways of understanding 'power.' You may note that 'power over' is not really creative. It controls some aspects of what has been created. But to bring into being well informed, committed, sensitive people requires an entirely different kind of power, the kind of power that Abba embodies. The alternative to coercive power is often thought of as persuasive power. That is an important distinction. But it can be thought of still as limiting the one who is persuaded. Parents may, for example, explain to their children that if they do not eat their vegetables they cannot have dessert. They are not strictly coercing their children, but they are limiting their choices in the effort to 'persuade' them to eat vegetables. To avoid that misunderstanding of 'persuasive' power, I suggest that we speak of empowering power and liberating power. If a teacher offers a way of thinking that was not previously available to the student, the freedom of the student to choose is increased. If previously the student was not aware of having any choice in the matter at all and now discovers that she or he does have a choice, this is liberation from bondage. A good education involves a continual expansion of awareness of possibilities not previously imagined. A teacher's ability to stimulate the growth of the student in this way is a greater power than the ability of a bully to force a student to engage in some demeaning act. The power we attribute to Abba is of this superior variety." Cobb, Jesus' Abba, 138-139.

${ }^{99}$ Cobb, Jesus' Abba, 66. 
God is not culpable for the evil in the world, because evil is produced by the liberated choice of individuals who works against the will of God. ${ }^{100}$

This liberating power of God also affects the traditional understanding of God's omniscience. God can fail, therefore, he does not know everything that will happen. Cobb points out that Jesus could not have known that Jerusalem would have been destroyed. ${ }^{101}$ According to Cobb, for God to have this kind of foreknowledge would mean that God was outside of time and space. Cobb rightly points out that the biblical understanding of God is personal and historical, although he omits that Scripture also says that God knows the end from the beginning. ${ }^{102}$

Interestingly enough, while Cobb rejects omniscience that includes future occasions and a coercive omnipotence, his panentheism holds on to God's omnipresence. He would rather call God omni-spatial, meaning all standpoints are contained within the standpoint of God. He believes this better reflects an experiential based reality rather than a substantialist one. Nonetheless, God is everywhere, even if he does not know the future or have all power. ${ }^{103}$ Cobb removes the idea of God as a law-giver or judge from Christian theology; thus clearly informing his interpretation of the liberating power of God. ${ }^{104}$

\footnotetext{
${ }^{100}$ Cobb, Jesus' Abba, 66.

${ }^{101}$ Cobb, Jesus' Abba, 18.

${ }^{102}$ Cf. Isa 46:9-11.

${ }^{103}$ Cobb, God-World, 78-79.

${ }^{104}$ Cobb, Reclaiming, 101-102.
} 


\section{Summary}

In summary, Cobb's ontology of God seeks to move theology away from the substantialist view of reality and God, and towards the newer experiential based understanding of reality and the ontology of God which that view produces. ${ }^{105}$ This transition affects multiple aspects of the ontology of God and the relationship between God and the world. First of all, the cosmos is in a panentheistic relationship with God. All of the created world is experientially within the non-substantialist physical pole of God, while the mental pole of God transcends the created world to preserve the personal nature of God. Cobb also holds to a historical view of this personal God who is in a liberating relationship with all of creation. God's creative will is the lure for all of creation to respond to. By accepting this will, creation is a part of God's consequent nature to a greater degree. Cobb calls this consequent nature the immanent incarnation of the Logos within creation, the Christ, as well as the Kingdom or peace of God, once it is fully realized.

While there are some valuable corrections of classical theism within Cobb's theology, is it possible that there are places where Cobb gives too much significance to Whitehead, thus shifting the understanding of who God is away from the biblical text?

${ }^{105} \mathrm{Cobb}$ is careful to not suggest that theology not simply follow the majority of scientific opinion nor just look for any God. He is seeking for an understanding of a Christian God. "Our view of God must not be a reluctant compromise with science and modernity. It must be fully rooted in our present situation, fully affirming what the evidence suggests. I do not mean that we should believe only what a majority of the wise men of our time believe. The majority have rarely been right. In any case, when I speak of finding God afresh in our time I am speaking as a Christian. Christians are those who have been shaped in their perception of meaning and importance and in the very structure of their existence by Jesus. What we as Christians seek when we seek God in our time is not sought by all. Our questions are not the same as those that have been formed by the dominant philosophy. We are driven by concerns that do not drive all men. The God we seek is the Christian God. But what we today find as the Christian God may differ profoundly from the God of Augustine, of Thomas, of Calvin, of Schleiermacher, or of Earth." Cobb, Is it too late?, 135 . 
Cobb does propose a historical view of God's ontology, which Scripture also appears to agree with. Cobb presents a liberated view of the divine and human relationship regarding free will and choice, which is also in line with a Wesleyan/Arminian view of Scripture. Is the panentheistic nature of God's ontology, integrated with the ontology of creation, an accommodation towards pantheism that Scripture cannot support? Cobb recognizes the Hebrew mindset of Yahweh being personally engaged with history and the people of Israel, and affirms the distinction of the person of God from the creation he interacts with. ${ }^{106} \mathrm{Cobb}$ expresses the transcendent lure of God's primordial will drawing all of creation forward, but it is that very creative pull that also allows for God to immanently work in each part of his creation to the point of what Cobb calls a radical incarnation. ${ }^{107}$

Does the distinction of divine natures, as an interpretation of the Trinity, fall short in light of the Scriptures portrayal of the three persons of the Trinity or is Whiteheads philosophy a better expression of the ontology of the Trinity as Cobb suggests it to be? Cobb recognizes that the NT writers describe Jesus as divine. Rather than agreeing with this, he instead suggests that the NT writers, especially in the Gospel of John, were over emphasizing the divinity of Jesus, rather than recognizing Jesus as a unique example of the incarnate Logos. ${ }^{108}$ Cobb demonstrates his acceptance of philosophy as a necessary interpreter of Scripture over and above the text of Scripture itself. ${ }^{109} \mathrm{He}$ does consistently

${ }^{106}$ Cobb, Structure, 99.

${ }^{107}$ Cobb, Pastoral Care, 49-51.

${ }^{108}$ Cobb, Jesus' Abba, 25.

${ }^{109}$ Cobb, Good News, 46. It is true to say that most if not all theologians have influences from their own philosophical presuppositions. Cobb believes that Whitehead is a less fragmented option for understanding the ideal Christian experience expressed in the NT. Is this the best way to engage with 
follow this predisposition to philosophy in his construction of the ontology of God, thus keeping consistency within his own system of ontological reality.

The very panentheistic nature of Cobb's ontology of God engages the ontological nature of divine-human indwelling. God and humanity co-constitute each other's beings by mutual participation in the experiential-based relationship of reality. For a fuller understanding of this mutual indwelling relationship, this study will turn next to Cobb's construction of the ontology of humanity.

\section{Ontology of Humanity}

Cobb's ontology of humanity is based once again within his energy-based panentheistic system. This study will therefore progress through the basic ontology of humanity related to energy-events, through the more complicated evolution of the structure of human existence, to Cobb's pinnacle of spiritual existence. This progression includes the significance of the dominant occasion, the evolutionary process of humanity's consciousness, the person's relationship to their body, spirit-centered wholeness, and finally corporate personhood.

\section{Occasions of Experience}

For Cobb, human ontology, like all the rest of reality, is made up of a process of occasions which take place within both conscious and unconscious awareness. Cobb believes that the majority of the experiential occasions which take place are unconscious. The unconscious awareness constitutes the inorganic entities of the world, as well as the

Scripture? Is it possible to bracket our presuppositions when we are aware of them and take them to Scripture to be evaluated by Scripture itself? Peckham and Canale both suggest the possibility of this kind of hermeneutic. Canale, "Deconstructing."; Peckham, "Analogy of Scripture." 
physical poles of human ontology. ${ }^{110}$ Each occasion of experience has a certain degree of awareness as it incorporates itself into the prehensive process of the events that have

come before it. Cobb says that this awareness can be called a feeling in the sense that it is a basic awareness, which is an experiential feeling. ${ }^{111}$

The degree of awareness can eventually be great enough that one could differentiate occasions by kind rather than degree. ${ }^{112}$ Therefore, organic and inorganic kinds of occurrences can be differentiated by their level of awareness, and physical and mental occurrences can be differentiated as well. ${ }^{113}$ The physical events or occurrences are simply a part of a repetitive process of repeated occurrences, while the mental ones have a conscious awareness to a greater degree which retains prehension of the preceding

\footnotetext{
${ }^{110} \mathrm{Cobb}$ continues to reject the substantialist view of reality, including any kind of mental substance proposed by the dualism of Descartes. A "substance" is a community of process of electromagnetic events. "....neither the analogy of the physicist's particles nor the direct evidence justifies the idea of a mental substance. In the first place, by no means all the functioning of the unconscious is " mental" in any ordinary sense. In the second place, the notion of substance introduces the idea of stable endurance through time - if not of a wholly unempirical and unthinkable something - which is not called for by the evidence. There are continuities within the unconscious, but they are the kinds of continuities to be found within a process. What is to be affirmed, in affirming the unconscious, is a succession of experiences in which continuity is established by reenactment rather than by static identity." Cobb, Structure, 32 .
}

111 "Electromagnetic events were occurring for a long time before there were men, or even animals, around. They must have had their reality in themselves, and that makes sense only if we also affirm that they had reality for themselves. To have reality for itself an entity must feel. Since feeling is the most primitive form of "taking account of," and since there is excellent evidence that electromagnetic events do take account of their environment, it is reasonable to affirm that they are instances of unconscious feeling." Cobb, Is it too late?, 111.

${ }^{112}$ Cobb once again describing and making use of Whitehead's understanding. Cobb, Natural Theology, 26.

113 "The things we ordinarily call alive are not individual events but vast societies of events, such as a mouse or a tree. These societies are alive to whatever extent there are events among their members whose lives affect the social organization as a whole. Along with the novel response goes a heightening of feeling. A living event takes account of much more of its world, with far greater intensity, than does an inorganic event. The inorganic event achieves its unity by simple repetition of simple feelings." Cobb, Is it too late?, 112. The inclusion of the simple inorganic events within the larger ecological system is part of the reasoning that Cobb uses to place value upon the larger ecological concern and human responsibility to be aware of it. 
occurrences, even though this is mostly stored within the unconscious. The evidence of such prehension is found in the practice of deep psychology, where the memories within the unconscious can be accessed. ${ }^{114}$

When one of the mental occurrences gains enough influence over the other occurrences of its immediate environment, i.e. the body, it becomes the dominant occasion in Whitehead and Cobb's terminology. It is this dominant occasion that provides order to the rest of the occurrences and is therefore recognized by Whitehead and Cobb as the possible soul or source of personhood for the individual. A better understanding of this dominant occasion is where this research turns next.

\section{Dominant Occasion}

Different types of energy-events have greater or lesser complexity. The less complexity they have the more passive the role that they play in making up the process which is the cosmos. But there are experiential occasions that have an active role. These occasions are more complex and probably for this reason are referred to by both Whitehead and Cobb as occasions of experience, rather than the simple occasion. ${ }^{115}$ Cobb, once again relying on Whitehead's analysis of process, states that the process of the cosmos is a succession of atomic units, not in a substantialist way of thinking, but rather as individual occasions of human experience. Among these occasions there are those which constitute the psyche of an individual and these are called the dominant

${ }^{114}$ Cobb, Natural Theology, 42-43.

115 "I use also at times the term "occasion of experience." This is a Whiteheadian term, and my use of it expresses my acceptance of and dependence on Whitehead's analysis of process. He holds that the process which is a man's experience through time is composed of atomic units. The process as a whole is the succession of these atomic units which are the individual occasions of human experience. An occasion of human experience is human existence at a moment." Cobb, Structure, 33. 
occasion of experience for that individual. In Cobb's view, these dominant occasions are true of both animal and human, as all animals have the possibility for the composition of a soul. $^{116}$

Ontologically speaking, Cobb clarifies, there is no difference between general occasions of experience and the dominant occasions. The role which they play, however, reveals a greater complexity for the dominant occurrences. Cobb says that only these dominant occasions can develop in a central nervous system and enjoy the possibility of consciousness. ${ }^{117}$ The function of participating in or "jointly constituting" occurrences from the past, including those of previous dominant occasions in the same organism, is largely unconscious. But the dominant occasion plays the role of not only gathering these occurrences in the memory of the individual, but also organizing them, which allows for decisions to be based on the past occasions. ${ }^{118}$

The complex active organization of stimuli surrounding an organism, human or animal, is not the whole of the role of the dominant occasion. The dominant occasion then holds these organized occasions in a sort of continuity from birth to death of the organism. It is by degree of continuity that Cobb identifies whether the organism is a higher or lower life form. ${ }^{119}$

Cobb argues for an emergence of the consciousness of humanity from dominant occasions, whose sole purpose is the survival of the physical organism to the preservation

\footnotetext{
${ }^{116}$ Cobb, Structure, 33.

${ }^{117}$ Cobb, Structure, 34.

${ }^{118}$ Cobb, Structure, 34.

${ }^{119}$ Cobb, Structure, 36.
} 
of the psyche as a whole. ${ }^{120}$ This was a historical process which Cobb exemplified in the process of humanity in different cultures. ${ }^{121}$ It is the crossing over from the preservation of the physical self to the psychic self where the differentiation of human from animal began. ${ }^{122}$ Cobb says this can be seen in the prioritization of symbols in higher lifeforms, most clearly in the use of language. ${ }^{123}$

The human race came to a place where consciousness became reflective. ${ }^{124}$ The dominant occasion began to not just respond to the stimuli around the organism, but to reflect upon, organize, and make decisions based on the occasions of stimuli around it. This reflection is upon the unconscious memory of the individual person which constitutes the psyche or soul. ${ }^{125}$

\section{${ }^{120}$ Cobb, Structure, 39.}

${ }^{121}$ These cultures include the general western culture, eastern culture with Buddhism as the example, and the Christian culture, of course, starting with the early history of Biblical literature, through the stage of the prophets, up to the axial change which happened just before Christ and then into the spiritual structure of Christian existence during the time of Paul. This is the basic historical process which Cobb describes in The Structure of Christian Existence.

${ }^{122}$ Cobb, Structure, 39.

123 "Of these two modes of psychic activity, the intelligent interpretation and response to signals was prior, since it was in continuity with animal existence. For man, however, symbolization was primary. It encompassed everything, including the practical dealing with the environment, overlaying it with new meaning and relating it thereby with the rest of experience. The dominance of the symbolization based on unconscious processes was as often inhibiting of intelligent action as it was productive of it." Cobb, Structure, 41.

${ }^{124}$ In summary of the evolutionary emergence of the structure of human existence, Cobb writes the following: "The structure of primitive existence may now be summarily described as follows. It continued the receptive awareness and the consciousness in terms of signals structurally unchanged. It added an immense richness to the unconscious, which, by the continuity of its life, constituted the successive occasions of human experience as a unified soul. This unconscious life was characterized by a vast autonomous development, which in its turn brought into being the reflective consciousness. This was organized by means of the symbols developed in the unconscious. Thus the older and more primitive aspects of consciousness continued relatively independent of the unconscious, while the new and dominant segment of consciousness was itself primarily a function of the unconscious." Cobb, Structure, 45.

${ }^{125}$ Cobb, Structure, 36. 
Cobb's next stage of the evolution of human consciousness is the transition to the axial human. As the reflective conscious grew in strength and organized more and more of the process in the continuity of occasions which makes up an individual, there was a time when the rationalization grew to greater significance for human kind. The axial person, according to Cobb, was then able to dispel the mystic, not only for himself or herself, but also for others. ${ }^{126}$ The dominant occasion, as the reflective conscious gained a unity within itself, which Cobb calls a "central determining perspective."127 The reflective conscious then became the seat of existence for humanity, thus dispelling myth for the sake of the rational. ${ }^{128}$

Cobb argues, however, that the structure of existence does not end with the axial for the Christian. Christianity has moved from the axial to the spiritual. Before the axial emergence as the basis of existence was the transcendent Holy Spirit of God. This has been processed through the axial rationale of the reflective conscious to turn toward the human spirit, rather than the Holy Spirit. For Cobb, spiritual existence is the new transcendent structure of existence within the Christian community. ${ }^{129}$

126 "The reflective consciousness, through thousands of years of civilization, became increasingly rational in widening areas. There were many individuals who came to be increasingly at home in this world of rational consciousness and increasingly estranged from the mythical world that still controlled their situation. Finally, men appeared who, from the perspective of this strengthened rationality, could effectively destroy the power of the mythical world not only for themselves but for many others as well. This drastic break with the mythical age constituted the axial period." Cobb, Structure, 53.

${ }^{127}$ Cobb, Structure, 54-55.
${ }^{128}$ Cobb, Structure, 54-55.

129 'In the preceding paragraphs, the term 'spirit' has been used repeatedly to refer to the human spirit. It has been used without precise definition and in a way that hardly distinguishes it from my use of person. This nontechnical use of spirit is also characteristic of the NT. The Christian community did not have the philosopher's concern for terminological precision, and even Paul uses his major anthropological terms in ways that are often interchangeable. Spirit" can mean the self, the soul, attitude, or will. Probably all its meanings reflect uses that are independent of the prophetic understanding of man. Nevertheless, this term is here selected to designate the new element in Christian existence. This use of the term receives general support from the NT, and is also in accord with one of the meanings widely given to it in 


\section{The Human Spirit}

Given that spirituality is the newest and highest structure of Christian experience, this research will now turn to Cobb's understanding of the human spirit and how it is related to the personhood of the individual and thus the ontology of humanity. Cobb calls the spirit the highest expression of the life of the Christian, particularly when it functions in its fullest response to the divine Spirit, thus becoming self-actualized. ${ }^{130}$ The question that follows then is: what is the spirit? How does Cobb define the spirit?

Cobb offers several different theories and rejects them before he comes to his self-transcendent definition of spirit. Some in Christianity, reports Cobb, have identified the spirit with vertical depth moving towards the mystical. Cobb rejects this definition because it has no essential value for the everyday life of the Christian. Others have identified the spirit with emotions and desire, reason, thought, or other aspects of the psyche. This identification, with one aspect of the psyche, Cobb rejects as a distortion of the spirit. In agreement with Reinhold Niebuhr, Cobb suggests that the spirit is transcendent of the psyche. ${ }^{131}$ The spirit of an individual is able to transcend or "look at" and "take responsibility" for all of the aspects of the psyche. ${ }^{132}$

In the evolving structure of human existence, Cobb believes that when the spirit is

contemporary usage. In what follows, 'spirit' refers to the radically self-transcending character of human existence that emerged in the Christian community. In this sense, spiritual existence is a further development of personal existence." Cobb, Structure, 118-119.

\footnotetext{
${ }^{130}$ Cobb, Good News, 155.

${ }^{131}$ Cobb, Good News, 155-156.

${ }^{132}$ Cobb, Pastoral Care, 13.
} 
able to transcend the self it is at that moment when personal identity is established. ${ }^{133}$

Cobb seems to be willing to tie the center of existence with the will of the individual. It is the responsible center for organizing all of the fellow occasions of an organism. It is always open to the process of change and is responsible for changing itself. The transcendent-accepting-self of this responsibility for change is the "I." The "I" is not identified with any single aspect of the psyche and must maintain its transcendence of these other aspects. ${ }^{134}$

The "I", however must recognize that is does not have control over everything. Cobb believes that there are things beyond the I's control, including strong emotions inside the self, as well as events which are outside of the self. Cobb places these things under the control of the "demand of God." Once the "I" has accepted this lack of control and self-limitation it then transcends this limited self and becomes responsible for both what is inside and outside of its control. This full transcendence is recognized as spirit. For Cobb then, the spiritual existence is "radical self-transcending existence."135

Cobb also describes this in more theological terminology. The natural depravity

${ }^{133}$ Cobb, Structure, 123-124.

${ }^{134}$ Cobb, Structure, 123-124.

135 " The emergence of that ' $I$ ' marks the advent of personal existence. But the personal 'I' cannot be responsible for what it cannot control. It cannot be responsible for the occurrence of particular emotions, only for channeling them into righteous action. It cannot be responsible for the limits of its own capacity. It cannot be responsible for itself as it is given to itself. Thus, the 'I' of personal existence transcends every other element in the reflective consciousness, but it does not transcend itself. The message of Jesus on the one hand and the experience of the Holy Spirit, on the other, broke through this last barrier to total responsibility. The essential demand of God has to do precisely with those dimensions of selfhood which the personal 'I' cannot control. To accept those demands and to accept responsibility to live in terms of them is to accept radical responsibility for oneself, and that is, at same time to transcend one's self. That means that the new spiritual I is responsible both for what it is and for what it is not, both for what lies in its power and for what lies beyond its power. For the spiritual I need not remain itself but can, instead, always transcended self. Thus, spiritual existence is radically self-transcending existence." Cobb, Structure, 123124. 
of man or the distortion of the will is based on a self that is identified with an aspect of the psyche, such as selfish desire. The will must then be open to the transforming power of the grace of God. Once the self has accepted its limitation of the selfish desire which it cannot control and the grace of God which can transform it, it would then truly be transformed. ${ }^{136}$ Applying Cobb's previous terminology, the transformation would be the distorted will's transcendence into spiritual existence.

With all the talk of spiritual transcendence, one might expect Cobb to advocate for a substantial dualism in order to make the transcendence complete. Cobb, however, is strongly opposed to such a dualism and instead suggests what he calls spirit-centered wholeness.

\section{Spirit-Centered Wholeness}

Cobb rejects dualism on multiple levels. He rejects the radical dualism of Sartre between human consciousness and the physical world. He rejects a dualism of the person and the body as well as the person, body, and environment. Cobb also rejects the dualism of right and wrong, good and evil, and will and desire. ${ }^{137}$ Cobb is also careful, however, not to turn to physical determinism and consider a person to be their body. He presents a much more delicate and interdependent understanding.

Cobb rejects the identification of one's person with one's body for two main reasons:

The first is that a sole focus on the body implies a rejection of the soul and too

${ }^{136}$ Cobb, Sustainability, 11.

137 “The ideal to which I am pointing by "wholeness" rejects this dualism of right and wrong, good and evil, will and desire. It accepts human reality as it is with all of its wants and desires." Cobb, Good News, 139-140 
heavily identifies the person with their body. In this way a person would also be their corpse and the value of people would be based on the attractiveness and functionality of their physicality. Therefore, those who are disabled or less attractive would be less valuable.

Cobb's second reason for rejecting pure physicality is that it suggests that the body/person is more unified within itself and separated from everything else around it. ${ }^{138}$ Cobb rejects that the soul is as separate as some Greeks and Christians have affirmed. ${ }^{139}$ He states that "a person does not exist before his body or apart from his body." 140 The person gains life through the body and expresses itself through the body. ${ }^{141}$ Cobb believes that there is a hierarchy of relatedness of personal consciousness, both with the different parts of the body as well as the environment. The part of the body most related to the person is the brain. When the brain is affected the person is much more affected than when something happens to a toenail. In relation to the environment, Cobb suggests that words being spoken to a person are more affective than the skin on one's left heel or than the hair on one's head. The skin and hair are also less related to the person than the body of the other person they are having sexual relations with. Cobb advocates a complex interdependency between the person, the body, and the environment. ${ }^{142}$ This demonstrates the previously described understanding of energy-relations based reality of

${ }^{138}$ Cobb, Is It Too Late?: A Theology of Ecology, 87-90.

${ }^{139}$ Cobb, Is It Too Late?: A Theology of Ecology, 87-90.

${ }^{140}$ Cobb, Is It Too Late?: A Theology of Ecology, 87-90.

${ }^{141}$ Cobb, Is It Too Late?: A Theology of Ecology, 87-90.

142 This entire train of thought is found in Cobb's discussion concerning the importance of human responsibility regarding ecological concerns. Cobb, Is It Too Late?, 87-90. 
Cobb's panentheistic cosmos.

Cobb also rejects any kind of dualism within the person. The dualistic approach to right and wrong, good and evil, and will and desire is rejected by Cobb. ${ }^{143}$ He prefers instead to seek the ideal of wholeness. This is a hierarchical organization of the different aspects of the psyche which gives each its value in the most balanced order. ${ }^{144}$ This, of course, is centered in the idea of the transcendent spirit which can observe and take responsibility for all those different aspects, as discussed previously in this chapter. While wholeness is mostly inclusive for Cobb, it is not all-inclusive. The spirit for example is not included in the wholeness of the person, for then it would not be transcendent, or visa-versa make the rest of the person too transcendent. ${ }^{145}$ An example of this is the unbalanced lack of wholeness in some of history's spiritual leaders. Ghandi was spiritually dedicated to his cause but lacking wholeness because of his unbalance concerning his physicality, sexuality, social and family relationships. All of these suffered for his cause. ${ }^{146}$

Cobb describes wholeness as at-homeness, a radical acceptance of who one is and one's environment. ${ }^{147}$ The promise of wholeness is based on a trust of the intentions of

143 This same language can be found in two different sources from Cobb. "The ideal to which I am pointing by 'wholeness' rejects this dualism of right and wrong, good and evil, will and desire. It accepts human reality as it is with all of its wants and desires. It condemns nothing. It affirms that precisely when nothing is condemned, nothing becomes destructive. All one's impulses can be acknowledged and accepted for what they are. They should be viewed hierarchically as if some were more noble than others. Each is what it is and has its rightful place in the whole. Sexuality is to be accepted and enjoyed as a pervasive aspect of life without guilt about that expression. In general a mark of wholeness is freedom from compulsiveness and legalistic rules." Cobb, Good News, 139-140; Cobb, "Wholeness," 229.

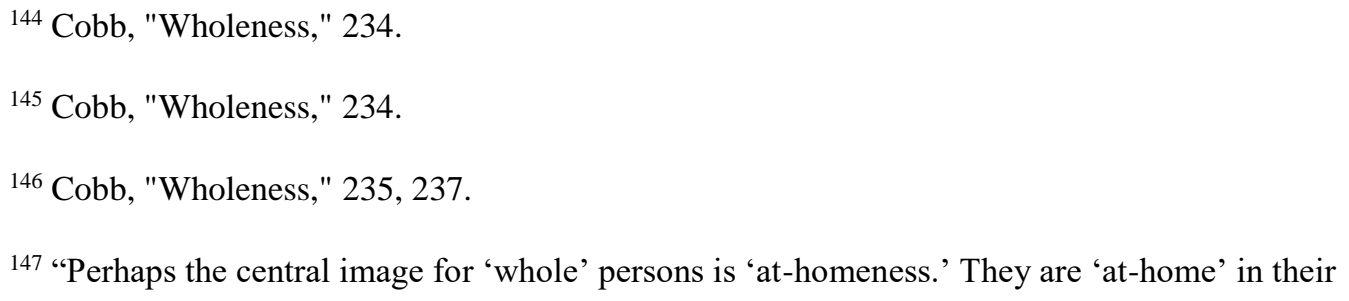


the Spirit to move one's spirit towards wholeness. This trust is so complete that the individual does not have to worry or strive towards wholeness, but rather can be content or "at-home" with who one's current state of wholeness. ${ }^{148}$ A whole person holds great power over others, not by coercion but by influence. When people are confronted by whole people they are forced to make decisions about their own lives because they can recognize their own lack of wholeness. ${ }^{149}$

Cobb's emphasis on wholeness and inter-relatedness between the person, the body, and the environment opens up the next important aspect of human ontology, which is corporate personhood. In fact for Cobb wholeness can only be experienced in the context of relationships with others. ${ }^{150}$

\section{Corporate Personhood}

For Cobb the understanding of personhood is very much tied to the evolutionary process of humanity. He describes the original primitive man as having a tribal immersed understanding of personhood. The person only has identity within their function in the

bodies, in their conscious and unconscious feelings and senses, in their human relationships, and in their total natural environment. They are 'at-home' with who they are, and therefore they are comfortable being just that. Because they are 'at-home' in themselves, they are free from defensiveness toward others. Others experience their warmth - that is their openness, their concern, and their affection. One is not the object of good deeds or just treatment from the whole person. One is the recipient of acceptance and understanding." Cobb, "Wholeness," 230.

148 "The attitude of trust in Spirit conduces to wholeness. It also makes the quest for wholeness less urgent. If one trusts the Spirit, one knows that one is all right as one is. One does not have to become whole in order to be alright. One is free to seek wholeness in service to the Spirit that makes for wholeness, because there is no need to become whole." Cobb, Good News, 149.

${ }^{149}$ Cobb suggests that in the completeness of wholeness things like fame and desire are only valuable in the forwarding of the individual's cause, not in adding to one's person because they are whole as they are. Cobb, "Wholeness," 233.

${ }^{150}$ Cobb, Good News, 139-140. 
tribe. ${ }^{151}$ The rise of axial person within human evolutionary history produced not just a new concept of the individual but an actual new individuality. ${ }^{152}$ By the dominant occurrence or seat of existence being transferred to the reflective consciousness, the individual is able to selectively, consciously participate in the occasions of reality in which it chooses to hold in continuity. This produces an actual freedom by which the individual can construct their own individuality. ${ }^{153}$

Cobb wants it to be clearly understood that this new individuality is not simply a change in perception, but a change in reality. Borrowing from Buddhism, Cobb understands the soul not as a substance but as an organization of occasions of experience. ${ }^{154}$ He states that ontologically there has always been individuality in the sense that one's self is a different series of unconscious experiential occasions, rather than another; this is true of both animal and human individuality. But after the axial shift this continuity becomes conscious, the reflective conscious evaluates and organizes the experiential occurrences in such a way that it holds the continuity of an individual's past, present, and potential future together. ${ }^{155}$

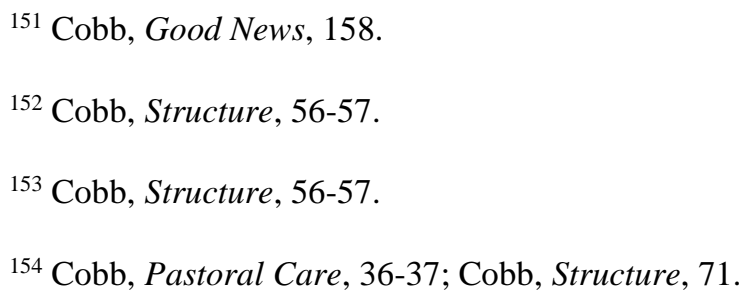

155 “Ontologically, therefore, not only is each occasion of human experience an individual, just as is each animal experience as well, but also the series of such occasions has a continuity and a cumulative character that constitute it as an individual series. In primitive man, however, this individuality was located in the unconscious, and although it must be emphasized when we compare human experience with that of animals, it was not what we think of as individuality today. When I think of myself as an individual, I think of that thread of consciousness that I can recall from the past and anticipate in the future and with which I can identify myself. To a large extent my conscious decisions are made on the basis of memories of past conscious experiences and anticipations of future ones. Thus I bind together this sequence into a chain that began with birth and ends with death. As an individual, I am that chain, and I perceive myself as clearly 
Cobb describes the shift in the history of Israel as a specific example. Early on the entire nation of Israel was the covenantal partner with God. Any sin of an individual was a sin of the whole. Cobb sees this reflected in the language of the $8^{\text {th }}$ century and earlier prophets. Starting in the $7^{\text {th }}$ Century, however, the prophets began to speak more of the individual responsibility and punishment related to the covenant. ${ }^{156}$ Cobb suggests that it is also the axial emergence in Israel that makes the shift from the external focus on the actions of keeping the law to the internal struggle of decision within the heart. The external actions were visible within the community and therefore the focus of the tribal mindset. The internal process was invisible and therefore not recognized until the axial change. This is also the reason, according to Cobb, for the connection between the invisible God and the invisible struggle within the heart. Cobb suggests that this may not have been plainly understood by the Hebrews, but it was an underlying theme. ${ }^{157}$

Cobb describes the rise of the civilized axial man, which moved away from the tribal corporate personhood, created a strong sense of isolation. The participation in the whole was no longer a given, but a hunger to fix the estrangement felt by the new axial individualism. Religion played a key role in this, both as a united system of symbols and

distinguished and sharply separated from all other individuals." Cobb, Structure, 55.

156 "In the eighth-century prophets, the vision was still one in which Yahweh and the nation were the covenant partners. It was the people as a whole who had sinned against God and who must suffer the just consequences of their disobedience. But by the seventh century, the collective personality of the people was giving way to the individual. According to Amos, the justice of God would bring destruction on the nation. But Jeremiah wondered why God allowed individual wicked men to prosper while individual righteous men suffered. He could not accept the view that the children should suffer for the sins of their parents and grandparents. This shift from the understanding of the people as a whole as the covenant partner of God to the idea that God deals with individuals as individuals is of such importance that we must pause to consider how it may have developed." Cobb, Structure, 102.

${ }^{157}$ Cobb, Structure, 103. 
also as means to overcome the isolation. ${ }^{158}$ The emphasis on the reflective consciousness identified the person with reason, to the point of thinking of the psyche as an independent substance. $^{159}$

Cobb however rejects the completely isolated understanding of personhood, both as an individual reality as well as the needed awareness of society. While an individual is endowed with a conscious choice to organize the continuity of experiential occasions, in a way that differentiates one individual from another's conscious continuity of conscious occasions, the relation between the conscious occasions of one individual and the unconscious occasions of another individual still exists. Cobb says that the entire experience of the world presents itself to every individual, but it is only the conscious occasions that are chosen by the reflective consciousness to chain together in continuity. The unconscious occasions, however, are still related to the individual. Therefore, Cobb concludes, reality is more of a social construct than we believe it to be. ${ }^{160}$

Cobb uses self-transcendence to suggest the way to a new corporate personhood found in global consciousness. ${ }^{161}$ Rather than tribal conformity of the self to the dominant

\footnotetext{
${ }^{158}$ Cobb, Structure, 61.

${ }^{159}$ Cobb, Pastoral Care, 36-37.
}

160 "Nevertheless, I believe that even for the highly conscious individual there are other relations to other individuals in the unconscious dimensions of experience. Our total experience in each moment is a selective synthesis of the whole world as it gives itself to be experienced. Important elements in that world are the past experiences of the individual in question, but the experiences of other men are also there to be appropriated. One's own past may outweigh the others in importance, but it does not exclude them. Hence, our experience as a whole is far more a social product than we ordinarily realize." Cobb, Structure, 55.

161 "In such existence, the individual exists only as a participant in the group. One derives one's being and meaning from the group so that one's interests are identical with the group interest. But in selftranscending selfhood, there is heightened capacity for independence from the group. The groupconsciousness that is involved is a free adoption of a perspective that relativizes one's own, whether or not it is shared by anyone else. It is not immersion in the shared experience of the group. Christian spirituality now requires of us a global consciousness." Cobb, Good News, 158. 
emotion of the tribe, a community of self-transcendent individuals can consciously choose to participate in the reality of the community by empathetically sharing experience with one another. ${ }^{162}$ The self-transcendent spirit, as previously discussed, transcends both reason and emotion. This allows the individual to take the responsibility for all aspects of the psyche, as well as responsibility for what is beyond itself. This means that a new corporate personhood can be and needs to be accomplished in global consciousness for the survival of the world. ${ }^{163}$

Cobb believes that in the twentieth century a new evolutionary existence was made possible as the exchange of global ideas and needs became more available. ${ }^{164}$ The empathetic hurts of one part of the world can be felt and accepted by other individuals of the world. Cobb accepts an inclusionist point of view, which ties humanity together with the other parts of creation. The concerns of the entire ecosystem are therefore constitutional with human reality. ${ }^{165}$ The self-transcendent spirit can accept the awareness of those other global occasions of experience, not only spatially but temporally as well, thus including responsibility for future generations. ${ }^{166}$ Cobb's later writings have taken a

${ }^{162}$ Cobb, Pastoral Care, 36-37.

${ }^{163}$ Cobb, Good News, 158.

${ }^{164}$ Cobb, Good News, 158.

${ }^{165} \mathrm{Cobb}$, Is it too late?, 84-85.

166 "Less evident than the spatial inclusiveness of the consciousness now required of Christians is the temporal scale. In what time frame should we interpret events? At one extreme is the dominant culture tendency to think in terms of a fiscal or academic year or a five-year plan, or, at most, a lifetime. At the other extreme is the possibility of placing events in the context of billions of years. The first tendency prevents us from dealing intelligently with current issues by blocking appropriate consideration of the effects of our actions on the foreseeable future. The second trivializes the importance of what occurs. I suggest that an appropriate global consciousness will concern itself with the history of life on this planet and see the present crisis in that overarching light." Cobb, Good News, 158. 
major turn from describing the metaphysics of theology to the ecological and economic crisis and the need for Christians to engage this process. A call to global consciousness is only one aspect of this argument, but it is relevant to understanding Cobb's ontology of humanity and reflective of his larger panentheistic understanding of the cosmos.

\section{Summary}

For Cobb, the ontology of humanity is tied together with the general ontology of the cosmos. The experiential-based understanding of the world being made up of a series of occasions is the basis for all of creation, including humanity. As humanity evolved there were certain occasions which took on the new characteristic of organizing the other occasions which made up the human individual. These dominant occasions evolved through the axial structure of human existence to the possible spiritual structure of Christian existence. It is through the transcendent spirit that the individual can not only take responsibility for their own existence, but also for the needs and concerns of the rest of creation. Human ontology is co-constitutional with the rest of cosmic ontology, which is consistent within Cobb's panentheistic model of cosmology.

In the next and final section of this chapter Cobb's ontology of God and his ontology of humanity will be brought together to gain an understanding of his panentheistic model of the ontology of divine-human indwelling.

\section{Ontological Nature of Divine-Human Indwelling}

Cobb offers a survey of Christian spirituality found in Can Christ Become Good News Again?, which might be helpful in introducing this section of the chapter. ${ }^{167} \mathrm{He}$

${ }^{167}$ Cobb, Good News, 152-155. 
suggests several different views of Christian spirituality, beginning with those which focus on the transcendence of God becoming immanent in some way. Cobb recognizes the influence of Calvin in the first two options he gives. ${ }^{168}$ Option number one suggests the basis of Christian spirituality is the will of God and Christians aligning themselves with that will. This first option is focused on the word of God. All of God's revealed will has been recorded in the Bible. The Christians are therefore supposed to align themselves with the will of God through obedience to the will of God as revealed in the Bible. Prayer in the first option is the preparation of the individual to accept the will revealed in Scripture. ${ }^{169}$ The second option Cobb acknowledges is one based on conscience and the choice between what is right and wrong. The Bible in this second option is a group of illustrations of what the right and wrong is and prayer is the surrender of the individual's selfish impulses to the divine directive. ${ }^{170}$

The third option which Cobb gives is one based on the influence of the Radical Reformation traditions. This is an invasive view of the divine Spirit which takes control of the individual believer, as seen in manifestations such as charismatic ecstatic speaking. The spirit has taken control of the vocal chords of the individual. Prayer in this tradition is the emptying of oneself to be a clear channel for the Holy Spirit to flow through. ${ }^{171}$

Cobb then moves to the immanent focused option for Christian spirituality, which

${ }^{168}$ Cobb, Good News, 152.

${ }^{169}$ Cobb, Good News, 152.

${ }^{170}$ Cobb also ties in these options with the need to defend the will of God for the atrocities in the world. So that individuals can accept evil as somehow being a part of God's will. Cobb, Good News, 152 153.

${ }^{171}$ Cobb, Good News, 153. 
he then develops into his own proposal. The more immanent focused spirituality has less to do with experiencing God in the ways in which he revealed himself in the past through things like Scripture and more to do with experiencing God in the here and now through our very beings. Cobb suggests that in this tradition the divine is often identified with the higher being of the individual. God is recognized as a ground of being in this tradition. Meditation is more important than prayer in this tradition. ${ }^{172}$

Cobb suggests that the Christian form of immanent spirituality must be based on Jesus of Nazareth as the norming factor. ${ }^{173}$ The Christ which was incarnated in Jesus is the Christ that can be incarnated in all. In the many different options in which Christ is expressed in the Christian community, Cobb chooses to speak only of life. Christ is the source of life, Christ is life. Christ is the lure and the threat of the newness and opportunity that is available to each individual for a more abundant life. Spirituality in this context is the "sensitivity" to these life opportunities being offered. ${ }^{174}$

The ontological nature of divine-human indwelling for Cobb is based on this understanding of spirituality. As Cobb's panentheistic ontology of God is brought together with the process based understanding of the ontology of humanity, the indwelling of one with the other is a mutual participation and inclusion of being. Cobb's understanding of indwelling will be explored in this section of the chapter by discussing his views on the following: transcendence and immanence, participation of being, being in Christ - the incarnation of the Logos, the peace and kingdom of God as the consequent

${ }^{172}$ Cobb, Good News, 153-154.

${ }^{173}$ Cobb, Good News, 154.

${ }^{174}$ Cobb, Good News, 154-155. 
nature of God, possibilities of possession, his statements on the sacraments, and finally in Cobb's concept of spirit-centered wholeness.

\section{Transcendence and Immanence}

The transcendence and immanence of God is expressed for Cobb in the idea of a dipolar God, as was described in the section on the ontology of God. All of the cosmic occasions of experience are experientially within God's "physical" pole, co-constituting that part of his experience. God is, however, not only made up of the cosmic occasions of experience but has a mental/spiritual pole which is beyond the cosmos. This is reflective of Cobb's ontology of humanity. Thus the body is an inseparable part of the being of a person and yet the individual is able to transcend physical determinism by his or her spirit.

The transcendent and immanent understanding of God is essential for Cobb's interpretation of the ontological nature of divine-human indwelling. ${ }^{175}$ For Cobb, what classical theology calls the indwelling of the spirit is the best that a substantial metaphysical system can do to describe the participation of a transcendent God within the experience of the cosmos. ${ }^{176}$ Cobb states that transcendence and immanence imply each other and for a process panentheistic system, God is immanent in every creature experientially participating within each occasion. Human experience is a special case for Cobb, owing to the possibility for a spiritual structure of existence. ${ }^{177}$

${ }^{175}$ Cobb and Slettom, Perspective II, 33-34.

${ }^{176}$ Cobb and Slettom, Perspective II, 33-34.

177 The conscious awareness of the dominant occasion which is described in Cobb's ontology of humanity, as it becomes more aware and organizes the experiences of the other passive occasions around it, also becomes more aware of God's participation. Cobb likens this to the spiritual senses which Wesley expressed. For Wesley it was an awakening of the soul which enabled the believer to sense things of a 
Cobb also believes both the Gospels and the writings of Paul support process theology in this idea of co-constitutive participation of being. The way in which Jesus refers to Abba is significantly immanent, for Cobb, along with Paul's use of the believer being "in Christ." 178 As will be explored more in the following chapter, Cobb interprets Paul's writing of Romans to express the co-constitutional nature of God within the experience of the Christian. ${ }^{179}$

\section{Participation in Being}

In Cobb's panentheistic system all things co-constitute all other things. God is a part of this co-constitution as well - the participation in the ontological being of everything else. God participates in the constitution of human reality and humans participate in the constitution of divine reality. "God is literally in us and we are literally in God." ${ }^{" 180}$ Cobb expresses this in the language of causality and freedom. According to Cobb, Hume denied any effective causality of the divine on the created world. Cobb suggests that God's causality of the world is effected by God's participation within every event of the world. ${ }^{181} \mathrm{God}$ is not the cause from behind, like someone pushing on a

spiritual nature, which has been unperceivable previously. ${ }^{177}$ Loyer, God's Love through the Spirit, 36-37. Cobb however believes that the awareness of God is just as much unconscious and conscious, considering every creature is participating in God and visa versa. "If God is present and working in us, as Wesley (and also process philosophy) affirms, there is nonsensory perception of God all the time.... Instead of speaking of new spiritual senses, we can think of nonsensuous experience of the divine presence in our lives and awareness of its salvific effects." Cobb, Grace and Responsibility, 75.

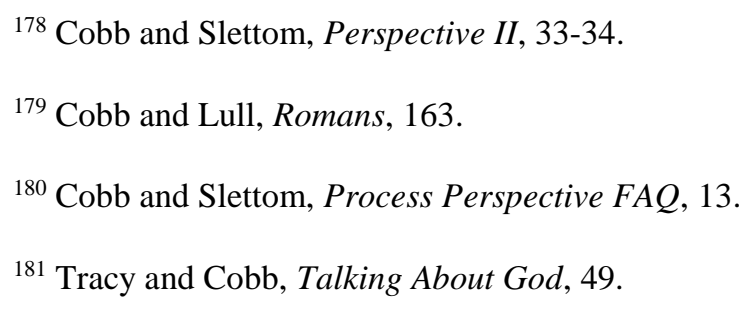


domino, but rather the effective cause from ahead. God is the lure toward new

possibilities. $^{182}$

As the lure to new possibilities, God is therefore the source of freedom. For Cobb, the individual is freed from simply following the pattern of habitual, physically determined patterns of existence by the possibility of choosing something new. ${ }^{183}$ The choosing of something new is self-constitution and the cause or lure of the new possibility is God. Therefore, it is God who is giving this freedom to the individual and, by doing so, participates in the constitution of the self. ${ }^{184}$ God's call towards freedom is towards the fullest self-constitution. Cobb states that God does not just offer this freedom to ease a habitual pattern of existence, but rather to free the individual out of habit and slothfulness into a better existence. The person not only has the possibility of constituting a better self-existence, but also to participate in the free constitution of others. ${ }^{185}$

Cobb brings this to a more personal level by suggesting that it is by the very presence of God participating in the constitution of an individual's life that there is a call to something more. In theological language, Cobb states that it is by God's grace that an

182 "Since nothing in the past world can be the cause of the effectiveness of these possibilities, that cause transcends the world. It is appropriate to call it God. To think of God as the cause of the effectiveness of these possibilities is to think of God as a factor in the self-constitution of each experience, for this is what it means to be a cause. According to our earlier consideration of causality, to think of God as the cause of the effectiveness of new possibilities - and thus the cause of freedom - is to think of God as participating in the constitution of experience." Tracy and Cobb, Talking About God, 53.

183 Tracy and Cobb, Talking About God, 53.

184 Tracy and Cobb, Talking About God, 53.

185 "God does not simply open up a space for our self-determination. God also urges or lures us to use that freedom to the fullest- to eschew, for example, those easy decisions to neglect our new possibilities for the sake of safer reiteration of past habits. God is thus not only the giver of freedom, but also the call to be more free. And finally the ethical element does enter. For God's call is not only that we so determine ourselves as to be more free, but also that we constitute ourselves so as to contribute to the freedom of others." Tracy and Cobb, Talking About God, 56. 
individual becomes free. ${ }^{186} \mathrm{Cobb}$ expands on this idea in his discussion of Wesley's theology. As a person is responsive to grace or cooperates with grace, that grace becomes part of the being of that person. "Concrete human beings" are constituted in part by God's presence within them. ${ }^{187}$ Cobb emphasizes Wesley's theology of the original image of God which states that God's presence was within humanity when they were brought into existence. This may give some reason to boast because God is coconstitutive of the being of humanity. On the other hand, states Cobb, without God humanity is nothing. ${ }^{188}$

Cobb offers the illustration of the writer and the reader as a way to understand this participation in the constitution of one another's beings. As the reader takes in the words that the author writes as possibilities to be contemplated and evaluated, those words become part of the reader's experience and thus existence. Cobb is careful to state that this is not a regular temporal succession nor is it observable by a third party in the correspondence of actions with the words. Rather this is an internal process of awareness within the reader. ${ }^{189}$

Cobb once again comes back to his definition of spirituality as an awareness of the divine. It is a constitutional awareness allowing God to participate in the being of the

186 Tracy and Cobb, Talking About God, 53.

187 "It is the Holy Spirit, which is the life of God within human beings. That means that concrete human beings are constituted in part by the presence of God within them. Human beings do not first exist in separation from God and then come into relation with God. Their very life is already God's presence within them. They exist by virtue of their inclusion of the divine life within them." Cobb, Grace and Responsibility, 40.

${ }^{188}$ Cobb, Grace and Responsibility, 40.

189 Tracy and Cobb, Talking About God, 48. 
individual. Cobb's understanding of the ontological nature of divine-human indwelling is then a participation in the constitution of both the human and the divine being. This immanent, participatory, constitutional indwelling is theologically described by Cobb as the incarnation of the Logos. Cobb's "in Christ" understanding of the Logos is where this research will turn next.

\section{In Christ - Incarnation of the Logos}

Cobb describes the Logos as a principle of order which is God's initial aim or primordial will. As discussed in the section of this chapter regarding the ontology of God, the Logos is one of the three possible modes or economic factors which make up Cobb's Trinity. Logos is the transcendent power of transformation or principle of order which is God's lure or initial aim for all of creation. ${ }^{190} \mathrm{Cobb}$ is careful to distinguish the transcendent Logos from the immanent, incarnate Christ. This is primarily because the logos is the novelty that has to struggle against the "habit, anxiety, and defensiveness" of the occasion which it seeks to creatively transform. "To whatever extent the new aim is successful, to that extent there is creative transformation. This creative transformation is Christ. Christ is thus the immanence or incarnation of the Logos in the world of living things and especially of human beings." ${ }^{" 191}$ Once a self has chosen to act according to the novelty which the Logos offers, the Logos partially constitutes the new occasion that is held in continuity with the previous occasions within reflective consciousness. As more and more occasions are constituted by the Logos, the creative transformation which Cobb

\footnotetext{
${ }^{190}$ Cobb, Pluralistic Age, 76.

${ }^{191}$ Cobb, Pluralistic Age, 76.
} 
describes as Christ is incarnated within that self. ${ }^{192}$

All of creation is incarnated by the Logos to a certain degree, all living things are able to be constituted by the Logos in the repetitive pattern which makes them what they are. ${ }^{193}$ Human beings however have a much greater potential to be incarnated by the Logos as they have the potential for self-actualization through the novelty of the Logos, rather than simple habitual repetition of the same occasions. ${ }^{194}$ The novelty which is offered by the Logos also offers freedom to the individual. ${ }^{195}$ The creative transformation of the self can be inhibited by the self-choosing, to go against the aim of the Logos. To choose against the Logos will eventually lead to death. A living thing which is not in the process of creative transformation is instead in the process of decay. ${ }^{196}$ Once again leaning on Whitehead's philosophy, Cobb agrees that "the world lives by its incarnation of God."

The freedom of any living thing to choose to accept or reject the lure of the Logos

192 "The Logos is now more, now less determinative in the constitution of occasions. Although the Logos is never entirely absent, resistance to creative transformation can be successful. What people believe, to what they attend, and what they decide affect how the Logos is incarnate within them." Cobb, Pluralistic Age, 138 .

${ }^{193}$ Cobb, Pluralistic Age, 76.

194 "In the events that make up ordinary physical objects, the aim in each moment is at little more than repetition or reenactment of what has been in the immediate past. But in living persons a new feature appears: The initial aim is at a relevant novelty rather than at reenactment. The novelty that is aimed at is one that allows maximum incorporation of elements from the past in a new synthesis. This novelty must struggle for actualization against habit, anxiety, and defensiveness." Cobb, Pluralistic Age, 76.

195 "The Logos makes possible free decision as well, which can curtail its effectiveness. But since this too is derived from the Logos it is not a competing principle of order. Hence the Logos as the principle of novelty is the only ground of order. All authentic thinking and speaking embodies this creative transformation as does all sensitivity of feeling and free imagination." Cobb, Pluralistic Age, 77.

${ }^{196}$ Cobb, Pluralistic Age, 77.

${ }^{197}$ Cobb, Pluralistic Age, 77. 
is the basis for Cobb's differentiation between Jesus as the Christ and the general incarnation of the Logos as Christ. Cobb believes that Jesus was so infused with the incarnation of the Logos that his very self was identified with Christ. ${ }^{198}$ Because of the self-identification of Jesus with Christ, Cobb believes that Jesus is different from the rest of creation in kind as well as by degree. ${ }^{199}$

As discussed in the human ontology section of this chapter, at some point the difference in degree becomes high enough for Cobb to say that an occasion becomes of a different kind based on its different level of function. The dominant occasion is different in kind as well as degree from other occasions. Perhaps in a similar way the difference between Jesus' incarnation of Christ and the rest of humanity's incarnation of Christ is both degree and kind. The word became identical to Jesus because he was the fullest incarnation of it. Jesus' self was so identified with Christ that he had direct insight and authority as divine. ${ }^{200}$ For Cobb, within the actions of Jesus were the actions of God

${ }^{198}$ Cobb, Pluralistic Age, 142.

${ }^{199}$ Cobb explains it this way: "The distinctiveness of Jesus can be spoken of in terms of Christ. Christ is the incarnate Logos. As such Christ is present in all things. The degree and the kind of Christ's presence varies. The fullest form of that presence is that in which he co-constitutes with the personal past the very selfhood of a person. That would be the paradigm of incarnation. In that case Christ would not simply be present in a person but would be that person. The distinctive structure of Jesus' existence was characterized by personal identity with the immanent Logos. Hence it is a matter of literal truth to affirm the identity of Jesus with Christ. In all things Christ is present. Jesus was Christ." Cobb, Pluralistic Age, 142. Others have suggested that Cobb actually does teach that Jesus is only Christ by degree rather than by kind. In personal correspondence with Cobb, he defended the position that Jesus is different both in degree and kind and said that he stood up against the difference-by-degree-only position. One scholar's understanding can be found in Integrated Theology. Lewis and Demarest, Integrative Theology, 295-296.

200 "The Logos is incarnate in all human beings and indeed in all creation, but it does not provide all with certainty of God's will or the authority of direct insight. If Jesus is a paradigm case of incarnation, and if the structure of his existence as it incarnates the Logos is explanatory of his assurance and authority, the possibility of a distinctive mode of incarnation should be considered. In the fullest incarnation of the Logos, its presence must constitute not only a necessary aspect of existence but the self as such. Embodiment of this structure of existence explains Jesus' certainty and authority." Cobb, Pluralistic Age, 138 . 
because the "I" of Jesus was so identified with the Logos. ${ }^{201}$

While other human beings may not be able to identify with the Logos as closely as Jesus did, the basis of the "I-Thou" relationship for every human being is the choice to accept the novel possibility presented by the Logos and synergize that occasion with the past occasions that the "I" is identified with. ${ }^{202}$ Divine-human indwelling in Cobb's understanding is the incarnation of the Logos within the human self. This is what it means to be in Christ and to have Christ within. All of creation is within God in Cobb's panentheistic system. Human beings, however, have a higher potential of selfactualization by accepting the creative transformation of the Logos and are thus more fully indwelt or incarnated by the Logos.

The initial aim of the Logos incarnated into the various forms of life in the cosmos is recognized as Christ. In Cobb's system, there is little difference between this incarnation and the final actualization for simple forms of repetitive life. ${ }^{203}$ But the more complex forms, especially human beings, are still in process towards self-actualization or what could be called the cumulative will of God, which Cobb relates to the Kingdom of God, Peace, and possibly the Holy Spirit. It is to this cumulative will that this research turns next.

201 "If Jesus existed in full unity with God's present purposes for him, then even the rules that he acknowledged as embodying God's past purposes could be freely set aside. It is appropriate to his style of teaching in which he directly presented the situation as he knew it without citing textual or empirical support. If he viewed reality from a perspective co-constituted by the immanence of the Logos in him, then what he saw could be unabashedly announced as there in the fullest and most objective sense possible for a creature. It is appropriate to his remarkable identification of his own ministry with the work of' God. If the 'I' who acted was co-constituted by the presence of the Logos in him, then God was indeed immediately active in the action." Cobb, Pluralistic Age, 141.

${ }^{202}$ Cobb, Pluralistic Age, 139-140.

${ }^{203}$ Cobb, Pluralistic Age, 76. 


\section{Peace and Kingdom - Consequent Nature of God}

As described earlier in the section on Cobb's understanding of the Trinity, Cobb and Suchocki describe the possible understanding of the Holy Spirit as the consequent nature or Kingdom of God. ${ }^{204}$ The primordial nature and the consequent nature are both from the terminology of Whitehead. Cobb recognizes that Whitehead and Pannenberg both refer to the Kingdom of God as the immanent realization of the will of God in creation. ${ }^{205}$ The primordial nature or creative aim, which is the Logos, can be accepted by individuals and constitute their very being, existence, and life. This acceptance in the incarnation of the Logos is Christ. The full realization of the primordial nature of God upon an organism of the cosmos would be the cumulative nature of God. ${ }^{206} \mathrm{Cobb}$ recognizes that this cumulative nature can possibly be identified with the Kingdom of God, the mysterious peace of Whitehead, and perhaps the Holy Spirit. ${ }^{207}$

The interaction of the Spirit with a human spirit is also significant for Cobb. The new spiritual structure of existence opens up the possibility of direct interaction between the Spirit, which is God, and the human spirit. ${ }^{208}$ Cobb makes his position clear that this

${ }^{204}$ Reference the previous section of this chapter as well as: Suchocki, "Cobb's Trinity."; Cobb, Pluralistic Age, 261-262.

${ }^{205}$ Cobb, Pluralistic Age, 261-262.

206 "Insofar as we instantiate that aim, the Spirit is born in us, becoming one with us in the creation of community. In other words, Christ offers creative transformation; the Spirit is creative transformation realized in the world. In this case, of course, the Spirit is not manifest as Spirit per se, but only in "works of mercy," or the unitive work of God with us in history." Suchocki, "Cobb's Trinity," 159.

207 "The justification is that the Spirit is regarded in Christianity as an eschatological phenomenon; it points to the End to which we move. And that End is God as the resurrection or Kingdom. The immanent presence of the Spirit now is anticipatory of that End, assuring us of it and uniting us with it. The Trinity can then be God, his Logos, and his Kingdom. The Logos is present with us as Christ; the Kingdom, as Spirit. Much of the book explains the justification for this way of thinking of Logos and Christ, and it is, in any case, in clear continuity with the tradition of Christian usage." Cobb, Pluralistic Age, 261-262.

${ }^{208}$ Cobb, Structure, 118. 
I-Thou interaction is not one of two persons over-and-against one another. For Cobb there is no spatial separation whatsoever, but truly an immanent indwelling relationship. ${ }^{209}$ Cobb illustrates the day to day interaction between the two in his morning preparation for the day. Whether the preparation is structured or relaxed, when something is brought to mind that needs to be done, reworked, or engaged, this is the working of the indwelling Holy Spirit. ${ }^{210}$

The ontological nature of divine human indwelling revealed by Cobb's consequent nature of God is an emergent process by which the individual has realized or fully actualized the creative aim of God in his or her life. The Spirit, which is the Lord, is God as an immanent presence within all of creation that experientially constitutes part of the being of that creation, which is essentially a reality of experiential occasions. In Cobb's system, this realized constitution is evidenced by the fruits of the Spirit in Paul's language, the realized peace in Whitehead's language, and what Suchocki calls acts of mercy. When Cobb speaks of the ecological crisis in the world, the spirit is the only eschatological hope which he can identify. For Cobb, as long as there is Spirit, there is life, and there is hope that the world could respond to the lure of God and eventually become the consequent nature of God. ${ }^{211}$

There are a few other topics in Cobb's writing that refer to the indwelling of the Spirit. They are in relationship to possession, the sacraments, and spirit-centered wholeness, to which we now turn.

\footnotetext{
${ }^{209}$ Cobb, Structure, 118.

${ }^{210}$ Cobb, Jesus' Abba, 62-63.

${ }^{211}$ Cobb, Is it too late?, 125, 130.
} 


\section{Possession}

Cobb moves away from the idea of the possession of the Spirit. He sees this as an old paradigm which might have been seen in the OT history of Israel, where the spirit would take over the self of the person. ${ }^{212}$ But with the axial transition in existence, the interaction between God and human beings has changed to a person to person understanding. Cobb writes that for Jesus the kingdom of God was an immanent reality which he was inviting his followers into. ${ }^{213}$ For Cobb, the early church moved away from Jesus' emphasis to a more empowerment based understanding of the Spirit which was made available by the resurrection of Jesus. ${ }^{214}$ As expressed in the previous section, Cobb sees the spiritual structure of existence as an immanent personal interaction between God, the divine Spirit, and the human spirit. Thus he leaves the idea of possession behind.

\section{Sacraments}

Regarding the sacraments, Cobb moves the idea of the presence of Christ in the sacraments forward into process thought. Cobb recognizes the objective nature of the presence of Christ in classical theology circles. It is within the elements of the Eucharist that the presence of Christ is and therefore taken in through the internalization of these substantial elements. ${ }^{215}$

For Cobb, however, Christ is truly present in the elements by memory. ${ }^{216}$ The

${ }^{212}$ Cobb, Structure, 116-117.

${ }^{213}$ Cobb, Structure, 116-117.

${ }^{214}$ Cobb, Structure, 116-117.

${ }^{215}$ Cobb and Slettom, Perspective II, 123.

216 "In the absence of a philosophical account of the real presence, Calvinists were influenced by the dominant mind-set of the time. The only thing that could be really present, from this point of view, was 
difference for Cobb, however, is that it does not have to be conscious memory, nor is it limited to the sacraments only. ${ }^{217}$ Because of Cobb's non-substantialist view of reality, Jesus is present in the actual moment because of one moment co-constituting another. A person does not have to consciously recall Christ for Him to be present in the sacrament because Jesus constituted the occasion of the last supper which is a part of the present occasion as it prehends the earlier occasion. ${ }^{218}$

Add to this Cobb's understanding of the incarnation of the Logos as Christ and one can easily see how Cobb's panentheistic system incorporates the presence of Christ within every occasion. This is true whether it is sacramental or not. Or perhaps one could say that all moments, all occasions would then be sacramental in regards to the presence of Christ. $^{219}$

the present. The present contains not only sense experience of the external world but also memory of the past. In the New Testament account of the Lord's Supper, Jesus tells his disciples to share bread and wine in memory of him. Hence the real presence could be understood to mean Jesus' presence to us through our conscious memory or recollection of his last supper, his death, and his rising to new life." Cobb and Slettom, Perspective II, 123.

217 "In this process account, the real presence is not focused narrowly on the bread and wine, as in the major tradition. Jesus is really present in the whole event, but especially in the experiences of those persons who participate. In this respect, the process account resembles the account of those who emphasize memory as the key element. It differs in that the real presence of Jesus does not depend on conscious memory." Cobb and Slettom, Perspective II, 124.

218 "In Whitehead's account, physical feelings function in the conformal stage of concrescence. That is, the becoming occasion conforms to those aspects of the past that it prehends. If the prehension of Jesus plays a significant role in the concrescence of the new occasion, there will be significant conformation to what is prehended. For Christians, conformation to Jesus is of highest importance." Cobb and Slettom, Perspective II, 124.

219 “'Obviously, when the real presence is understood in this way, it is not limited to the eucharist. This may be the most effective way to heighten the reality of the presence of those past events it celebrates, but it is not the only way. Jesus can be effectively present in nonsacramental churches and in the nonsacramental activities of all churches. Furthermore, this account does not minimize the value of the experience of persons in other religious traditions. Christians find the presence of Jesus in their lives to be of great value." Cobb and Slettom, Perspective II, 124-125. 


\section{Spirit-Centered Wholeness}

As previously discussed in the section of this chapter concerning the ontology of humanity, and specifically the human spirit, the human spirit is the transcendent self. ${ }^{220}$ Cobb's understanding of spirit-centered wholeness is the self-transcendent spirit taking full responsibility for all other parts of the person and being able to "look at" them in such a way that the different aspects of the psyche are not in control of the psyche. For Cobb, the interaction between the human spirit and the Holy Spirit is a mutual indwelling. ${ }^{221}$ The personhood of both is not only protected but the human personhood is enhanced by the indwelling of the divine Spirit. ${ }^{222}$

The human spirit is the transcendent self that chooses whether or not to accept the creative transformation of the Logos, thus becoming the incarnation of the Logos, which is Christ to one degree or another. It would also therefore be the spirit of the individual which would choose, based on mutual indwelling to be constituted by the divine Spirit in such a way as to be part of the kingdom of God. The consequent nature of God could be realized by the self-transcendent spirit of a person freely choosing to follow the lure of God's primordial nature. This would result in peace, shalom, wholeness.

\footnotetext{
${ }^{220}$ Cobb, Structure, 123-124.
}

221 "The relation of the primitive Christian believer to the Spirit was far more intimate than that. There was no imagery of spatial separation or of demand and obedience. There was, rather, the imagery of two spiritual realities, each fully responsible for itself and self-identical, nevertheless mutually indwelling each other. Whether this personal presence indwelling the believer was thought of as the Spirit or as Christ or as God in some other form does not really matter." Cobb, Structure, 118-119.

222 "But as we attempt to understand the character of Christian existence in the primitive community, the decisive point is that the personal God was known as inwardly present without loss of the sense of responsible personhood. Indeed, God was known as inwardly present in such a way as to enhance and accentuate the sense of personhood." Cobb, Structure, 118-119. 


\section{Summary and Conclusion}

In summary, Cobb's understanding of the ontological nature of divine-human indwelling is included within his panentheistic-non-substantialist cosmology. For Cobb, the ontology of God and the ontology of humanity are all intertwined as part of the same expansive collection of experiential occasions. All of the cosmos, including the world, humanity, and God, is made up of experiential occasions. Personhood is made up of a dominant occasion which holds together a continuity of occasions. God has a being within which all of creation exists, God holds together the continuity of all of the experiential occasions in the past and the ever-changing process of the present. The occasions which make up every individual person of humanity are then included in the being of God. The ontological nature of divine-human indwelling is not only an intermingling of divine/human realities, but a fully inclusive and co-constitutional blending of human/divine being.

Cobb, however seeks to make a distinction between God's personhood, and the personhood of each human being. This is explained by the dipolar nature of both God and human beings. The physical pole and the spiritual pole are interrelated and yet the spiritual pole is transcendent of the physical one. God's Spirit is therefore transcendent of all the cosmos and is able to hold everything together in such a way that God is responsible for luring all things towards actualization. The human spirit transcends the human self in such a way that it also can take responsibility for all things within its control and outside of its control by trusting in the divine Spirit, which is God.

Depending upon the philosophy of Whitehead, God's primordial nature and consequent nature are all a part of God as Spirit. The lure of the primordial nature and the peace of the consequent nature are available to the human spirit through the mutual 
indwelling of the co-constitution of the divine and human experiential occasions.

Humanity can therefore be incarnated by the creative aim of God and creatively transformed into Christ by greater and greater degrees. The ontology of humanity is included within the ontology of God. The divine Spirit and the Human spirit interact within this immanent reality to mutually indwell one another by participating in the constitution of one another's beings.

As minor as it may be in his thought, I applaud that fact that Cobb's work does attempt to engage the current understanding of physics, which most of Christian theology has stayed away from. Is he correct in assessing the majority of Christian theology as stuck in the substantialist mindset? I am unsure that the conclusions which he reaches are the best outcomes for understanding the ontological nature of divine-human indwelling. Cobb seems to rely too heavily on the idea that because God experientially engaged with all of creation his being is all-inclusive of the rest of reality. Cobb is willing to recognize the differentiation between one human being and another. ${ }^{223}$ If a human being is a clearly non-inclusive of other human beings, only loosely connected through the unconscious relationship between occasions of the environment around them, then why would it not also be possible that God could be a non-inclusive being or person as well?

In other words, if people are still independent communities of occasions from one another demonstrated in Cobb's description of the axial change in human development, even though current physics suggests everything is experientially-based and connected,

${ }^{223}$ He does so by moving humanity away from corporate personhood, through the isolation of the axial man, to a self-transcendent spiritual existence which allows for global consciousness. He recognizes the significance of each physical body which is integral to the individual person. The spirit of a human being must be related to a central nervous system and is ultimately connected in some way to the brain. 
then why would it be necessary to conclude that God is not a similar independent community of occasions, but rather an all-inclusive panentheistic being? Could the interaction between two people be a possible better example of the ontological nature or divine-human indwelling? Does God have to be panentheistic in order to be temporal and knowing of all past, present, and possibly future occasions? It seems that this could be an unnecessary conclusion.

It is important for theologians to engage the current scientific understanding of the day. It is important for theologians to try to understand what an energy-based reality means for Christian theology. It is also important to insist, when engaging current scientific understanding for the purpose of theology, that those scientific understandings be deconstructed, based on the presuppositions revealed in the biblical text, if the goal is to build a biblical theology.

While Cobb consistently builds his system on the philosophy of Whitehead, which gives it cohesion, he is willing to invoke this philosophy as an interpretive lens for Scripture. In the same way, Wesley allows classical theology and the philosophical presuppositions of his time to influence his interpretation of Scripture. The fourth chapter of this dissertation will be to comparatively look at the way in which these two systems of understanding affect Wesley's and Cobb's interpretations of the ontological nature of divine-human indwelling as revealed in Romans Chapters six through eight. 


\section{CHAPTER 4}

\section{COMPARISON AND CONTRAST OF JOHN WESLEY AND JOHN B. COBB JR. AND THEIR UNDERSTANDINGS OF THE ONTOLOGICAL NATURE OF DIVINE-HUMAN INDWELLING}

\section{Introduction}

In the previous chapters of this dissertation Wesley's and Cobb's understandings of the ontological nature of divine-human indwelling have been described and analyzed using the three research categories: ontology of God, ontology of humanity, and ontology of divine-human indwelling. In this chapter, rather than using all three categories of comparison, the research will focus on the last category, the ontological nature of divinehuman indwelling as this is the primary objective of this dissertation. ${ }^{1}$ This comparison will be accomplished by looking at the significant invokings of this category within the context of Romans Chapters 6-8. ${ }^{2}$ Not only will this offer a singular basis for a

\footnotetext{
${ }^{1}$ The first two categories (ontology of God and ontology of humanity) were essential for establishing a proper understanding of the third category (the ontology of divine-human indwelling). Once the proper understanding of the third category has been established, however, this is the major objective of the dissertation and thus the important point of comparison for this fourth chapter. It is also important to remember the specific working definition of ontological indwelling that is being used in this dissertation. The question is whether the reality/being of the divine is in some way merging or penetrating the reality/being of humanity. Whether this is a classical understanding like Wesley's in which the Holy Spirit is uniting formally with the soul or an inclusive panentheism like Cobb's in which the divine reality/being includes human as well as all other cosmic reality/being.

${ }^{2}$ Wesley and Cobb both directly interact with the book of Romans. Wesley wrote five of his first ten sermons based on Romans and two of these dealt with his doctrine of the Holy Spirit. Romans is one of the books which is central to the theology of Wesley. John D. Godsey, in tracing the use of Romans through Christian history, demonstrates the emphasis of John Wesley on the book of Romans. From his Aldersgate experience, following a reading of the book of Romans, to his sermons and notes being infused with references to Romans (including five of his first ten sermons), all were based on Romans. Three of these first five directly concern his theology of the Holy Spirit. "That Paul's thought in Romans was of central importance for Wesley's theology cannot be denied. Whether his interpretation is correct on all
} 
comparison between the two theologians, but it will also give opportunity to demonstrate how both Wesley's and Cobb's understanding of the ontological nature of divine-human indwelling affects their interpretation of this particular passage of Scripture. Both Wesley's and Cobb's interpretations will be compared with "representative scholarship," especially looking for places of agreement and challenges to their respective understandings of divine-human indwelling. ${ }^{3}$

This comparison will also allow for an evaluation of Cobb's claims to be a Wesleyan theologian and his suggestions that, given the progression of the scientific understanding of the world, Wesley might agree with the process view of reality and therefore its theology. ${ }^{4}$ In what ways does Cobb reflect Wesley's theology in his own? Is

points may be disputed. Certainly in his context Wesley had to accent the great doctrine of the Spirit in Romans 8 and the holy life of the children of God that resounds in Romans 12-15." Godsey, "Romans in Chrisitan Faith," 12-14. Cobb does not give Scripture as much authority as Wesley does. Cobb's system is primarily built on the philosophy of Whitehead, as previously discussed in Chapter 3 of this dissertation. Cobb does, however, directly interact with Romans by co-authoring a theological commentary on Romans. One of the theological themes, which he brings out in this commentary, is mutual immanence. And when outlining Romans in his introduction he sets Chapters 6-8 as a section directly addressing the participation in Christ's faithfulness by the means of the infusion of the Holy Spirit. Cobb and Lull, Romans, 19, 22-23.

${ }^{3}$ I have chosen to use the work of current recognized exegetical scholars rather than to do the exegetical work myself for this study. The scope of this dissertation does not allow for an exhaustive study of current scholarship on these passages on Romans. Because of the goals of this chapter to compare the ways in which the theology of Wesley and Cobb affect their interpretation of Scripture, the scholars that have been selected are exegetical scholars rather than more speculative or theological scholars. Cobb and Lull wrote a theological commentary rather than an exegetical one, they are also careful to identify that this work is also a commentary and they are planning to move along closely with the text. Cobb and Lull, Romans, 14-15. It is important to remember that Cobb is committed to build on the Historical Critical method and therefore can be evaluated based on exegetical work. Cobb, Jesus' Abba, xiv. The process community has been attempting to build bridges with exegetical work, but it has been limited. Lull is one of the process authors who has been building these bridges. John B. Cobb, Jr., David J. Lull, and Barry A. Woodbridge, "Introduction: Process Thought and New Testament Exegesis," Journal of the American Academy of Religion 47, no. 1 (1979). These selected scholars are representative of various faith traditions. Not all of the scholars will be mentioned for each point of study, but rather they will be mentioned for the point of discussion which their comments are most relevant. The selection process was done through an organic survey of commentaries on the book of Romans for those who most relevantly addressed the ontological concerns of this dissertation. For these reasons the following scholars have been engaged in this study: James D.G. Dunn (Church of Scotland; Methodist); Joseph A. Fitzmyer (American Catholic Priest/Society of Jesus); Earnest Kasemaan (Lutheran); Richard N. Longenecker (Evangelical); Douglas J. Moo (Evangelical); and Thomas R. Schreiner (Evangelical/Baptist).

\footnotetext{
${ }^{4}$ Cobb states that Wesley was a child of his times scientifically and that the dualistic humanity
} 
there good reason to believe Cobb when he claims that Wesley might agree with him if he had the same scientific understanding of reality available to him?

The significant points of comparison within these scriptural chapters are: the understanding of union with Christ through baptism (Romans 6), the life in the Spirit (Romans 8:1-17), and the relationship of humanity and general creation (Romans 8:18$23) .^{5}$

\title{
Romans Chapter Six: Baptism and Participation in Christ
}

\author{
Introduction
}

Romans 6:3-6 specifically speaks of the baptism of the believer into the death of Jesus Christ followed by the believer being raised into new life in Christ. Both Wesley and Cobb speak of this process of baptism as part of the union with Christ, which is directly related to divine-human indwelling. Wesley describes this union as an "ingrafting" of the believer into Christ and the Christian community. Cobb describes this

that Wesley held to was based on Newtonian physics which have proven to be wrong in the current time. Cobb, Grace and Responsibility, 51-52. Cobb speculates that Wesley himself would have likely changed his views if he had the knowledge of current scientific understanding. This scientific update, however, if you will, is not the crux of Cobb's argument that Wesley held to a panentheistic view of God-World reality. Cobb interprets Wesley's view on omnipresence as God being in all things. Cobb suggests, that for Wesley, the Holy Spirit animates all of creation, not only human beings, and that this therefore means that God is present in all and all is within God's being. Cobb, Grace and Responsibility, 51. Cobb also discusses Wesley's differentiation from the enthusiasts of his time because Wesley did not view the Holy Spirit as something coming upon the person from outside and possessing them to do supernatural things; but rather that the Holy Spirit was already inside, constituting a part of the being of the person. Cobb therefore identifies Wesley more with the mystics than the enthusiasts, based on an already existing union with Christ. Cobb, Grace and Responsibility, 46-47. Cobb correctly points out that Wesley believed that human beings were originally created with the Holy Spirit inside of them, thus constituting a part of their being. Cobb, Grace and Responsibility, 40.

${ }^{5}$ While Paul himself may deal with passages that would be relevant to this discussion in Chapter 7 of Romans, Wesley and Cobb do not significantly address these issues; such as indwelling sin. Therefore, the listed passages are the ones which will be engaged in this study. 
union in terms of a non-substantialist process view of reality, emphasizing a participation in the faithfulness of Jesus.

\section{John Wesley: Ingrafted into Christ}

Baptism, for Wesley, is a sign of the inward grace that is enacted upon the soul of the believer to bring that believer into a new life found in a union with Christ. Wesley did not write a great deal on baptism, due to the practical nature of his theology. He was largely speaking to adults who had already been baptized. He did however reproduce a treatise originally written by his father Samuel Wesley, as well as some comparative statements regarding baptism and the new birth in his "New Birth" sermon. ${ }^{6}$ In Wesley's comments on Romans 6:3-4, his description of baptism is packed into a couple of very intentional statements. These comments bring this research to a study of baptism as the first significant point of comparison between Wesley and Cobb in this chapter on

Romans 6-8. Here is Wesley's commentary on verses three and four:

3. As many as have been baptized into Jesus Christ, have been baptized into his death - In baptism we, through faith, are ingrafted into Christ, and we draw new spiritual life from this new root, through his Spirit, who fashions us like unto himself, and particularly with regard to his death and resurrection. 4. We are buried with him-Alluding to the ancient manner of baptizing by immersion: that as Christ was raised from the dead by the glory - Glorious power, of the Father, so we also, by the same power, should rise again: and as he lives a new life in heaven, so we should walk in newness of life. This, says the apostle, our very baptism represents to us. ${ }^{7}$

There are key phrases within this quote which are the anchor points for describing Wesley's theology concerning baptism. The first of these is "through faith." The union or

\footnotetext{
${ }^{6}$ Brian C. Brewer, "Evangelical Anglicanism: John Wesley's Dialectical Theology of Baptism," The Evangelical Quarterly 83, no. 2 (2011): 109-110.

${ }^{7}$ John Wesley, Explanatory Notes Upon the New Testament, Fourth American ed. (New York: J. Soule and T. Mason, 1818), 388.
} 
"ingrafting" into Christ that happens is by the means of the Holy Spirit "through faith." That faith depends upon the application of the merits of Christ to the condition of original sin, and it is under this baleful influence that Wesley places all of humanity. ${ }^{8}$ By virtue of Christ's dying, the possibility of sin being atoned for, or destroyed in the life of the believer, is made possible. ${ }^{9}$ The first benefit of baptism which Wesley lists in "A Treatise on Baptism" is the washing away of the guilt of original sin and the application of the merits of Christ's death. The merits of Christ's death are applied to a person at baptism as they are washed and sanctified by the Holy Ghost. ${ }^{10}$ It is worth noticing that the merits applied are those of Christ, through faith, not the merits of the believer through some participation of the believer in the faithfulness of Christ.

The second benefit of baptism, the new covenant, is also linked to the phrase "through faith." Baptism is the "figure" of entering into a new covenant with Christ in which the believer receives a new heart and spirit. ${ }^{11}$ This is a covenant of grace rather than one of law and therefore it is to be entered into by faith. For Wesley, the entire process of what baptism represents is through faith. Another key phrase in Wesley's commentary on Romans 6:3-4 is what baptism "represents to us." Once again, baptism is only the "figure" of entering into the new covenant with Christ. Wesley clarifies his

\footnotetext{
${ }^{8}$ This condition of original sin includes infants. Wesley discusses infant baptism at some length, which proves interesting when one considers the relatively small amount that he wrote on baptism. This was clearly a question of practical ministry that Wesley had to provide answers for. John Wesley, $A$ Treatise on Baptism, Third ed., The Works of John Wesley, vol. 10 (London: Wesleyan Methodist Bookroom, 1872), 190-191, 198.

${ }^{9}$ Wesley, Explanatory Notes of NT, 388.

${ }^{10}$ Wesley, Treatise on Baptism, 190-191.

${ }^{11}$ Wesley, Treatise on Baptism, 191.
} 
position on the sacrament of baptism by distinguishing the very act of baptism from the new birth. While he believes that the most common place for the new birth to take place is at the time of baptism, the water itself is nothing more than an external sign or seal of the internal grace which the Holy Spirit works upon the soul. ${ }^{12}$

Wesley describes the new birth in terms of spiritual senses. When a child is born into the world for the first time they begin to see the light, hear, taste, touch, and feel things they have not sensed before. In the same way, a person is dead to the spiritual things of God until they are reborn or regenerated by the spirit and water. A person may be a person who is alive, but a dead Christian. Referencing Scripture, Wesley suggests that until a person is reborn they have eyes, but cannot see the light or glory of God, and ears, but cannot hear the voice of God. It is only at the time of the new birth when they can have any knowledge of God at all. It requires the new heart and mind of the new covenant for them to feel the peace of the joy of God. ${ }^{13}$ This new birth is the internal reality that is represented by the external sign of water baptism. A response of faith is required for the mere act of baptism to be the actual, effectual working of the Holy Spirit upon the soul. Wesley said that just as the body is different from the soul so the act of human washing with water is different from the cleansing and regenerating act of the Holy Ghost upon the soul. ${ }^{14}$

\footnotetext{
12 John Wesley is working through the Catechism of the Church of England and finding points of agreement concerning baptism. "'Q. What is baptism? A. Baptism is a sacrament, wherein Christ hath ordained the washing with water, to be a sign and seal of regeneration by his Spirit.' Here it is manifest, baptism, the sign, is spoken of as distinct from regeneration, the thing signified." Wesley, New Birth, 7374.

${ }^{13}$ Wesley, New Birth, 69-70.

14 "For what can be more plain, than that the one is an external, the other an internal, work; that the one is a visible, the other an invisible thing, and therefore wholly different from each other? - the one being an act of man, purifying the body; the other a change wrought by God in the soul: So that the former
} 
This dynamic accentuates another key phrase from the initial quote, "through the Spirit." All of the internal benefits of the external water baptism are enacted upon the soul by the Spirit of God. In his commentary on these verses of Romans, Wesley makes it clear that it is the same power which raised Christ from the grave which will make it possible for a believer to walk in the newness of life, leaving the old man (the fallen nature) dead in the grave. ${ }^{15}$

Wesley describes the new birth as the beginnings of a relationship with God as the Spirit works upon the soul and he calls this spiritual respiration. The breathing of God upon the soul and the soul breathing unto God. As the grace descends into the heart so praise ascends to God. It is by this spiritual respiration that the life of God is sustained within the soul. ${ }^{16}$

By this new birth, Wesley's third and fourth benefits of baptism are realized. The believer is changed from a child of wrath by nature to a child of God. To be a child of God is to be engrafted into the body of Christ, which is the church. ${ }^{17}$ "Ingrafted" is another key word from Wesley's commentary that was quoted at the beginning of this section. It is interesting that Wesley speaks of the engrafting of the believer within the body of Christ as also constituting the mystical union of the believer with Christ. Christ is

is just as distinguishable from the latter, as the soul from the body, or water from the Holy Ghost." Wesley, New Birth, 74.

15 "Our old man - Coeval with our being, and as old as the fall, our evil nature; a strong and beautiful expression for that entire depravity and corruption, which by nature spreads itself over the whole man, leaving no part uninfected. This in a believer is crucified with Christ, mortified, gradually killed, by virtue of our union with him: that the body of sin-All evil tempers, words, and actions, which are the members of the old man, Col 3:5 might be destroyed." Wesley, Explanatory Notes of NT, 388.

${ }^{16}$ Wesley, New Birth, 71.

${ }^{17}$ Wesley, Treatise on Baptism, 191-192. 
the head of the body and therefore an engrafting into the church as the body of Christ is also an engrafting into Christ. Wesley describes this engrafting as an internal benefit of grace infused in the soul and, once again, is represented by the external sign of baptism. The infusion of grace, he said, would not be wholly taken away unless the Holy Spirit is quenched from the life of the believer. ${ }^{18}$

Wesley's engrafting was associated with the gospel principles and concepts, as well as the gospel body of the Church. When commenting on Romans 6:17, Wesley suggests that the literal translation speaks of the believer's mind being molded or conformed to the "gospel precepts," as "liquid metals take the figure of the mould into which they are cast."19

Wesley's fifth and final benefit of baptism brings forth one final key phrase from his comments on Romans 6:3-4, "to walk in a newness of life." A child of wrath that has been made a child of God through the new birth is also considered an heir to the kingdom. Baptism, as the external sign of the internal new birth, can become the beginning of the kingdom life. Wesley wrote: "Baptism doth now save us, if we live answerable thereto; if we repent, believe, and obey the gospel: Supposing this, as it admits us into the Church here, so into glory hereafter."20

What are the implications of Wesley's understanding of the realities of baptism for the ontological nature of divine-human indwelling? Wesley clearly speaks of a union

${ }^{18}$ This speaks to Wesley's acceptance of both the ontological union of the Spirit within the soul as well as the ontological transformation of the believer, as their mind is being molded. Wesley, Treatise on Baptism, 191-192.

${ }^{19}$ Wesley, Explanatory Notes of NT, 390.

${ }^{20}$ Wesley, Treatise on Baptism, 191-192. 
of the believer with Christ through the process of the new birth, as well as the engrafting of the individual within the Body of Christ which is the church and the precepts of the gospel. Once again, Wesley uses the classical theological language of God as acting upon the soul of the believer to bring about the internal reality which is pointed to in the external act of baptism. The grace that is infused within the soul, which cannot be wholly removed unless the Spirit of God is quenched, reminds one of the image of God as the fruit of the indwelling of the Holy Spirit, which Wesley says can be lost if consistently rejected. $^{21}$

Baptism, assuming that the new birth takes place at the time of baptism, is also the beginning of what Wesley called spiritual respiration. The breathing in of the grace of God within the soul and the enacting of God upon the soul would require the presence of God, according to Wesley's theology regarding the inter-related nature of omnipresence and omnipotence. ${ }^{22}$ If God must be present in order to act, then in order for God to act upon the soul it would seem that he would need to be present within the soul. ${ }^{23}$ For Wesley, the ontological transformation of the soul requires the ontological union of divine reality with human reality. While Wesley does not specifically mention indwelling in relationship to baptism, there is language in his descriptions of baptism that links to his understanding of divine-human indwelling.

${ }^{21}$ See the "ontological divine-human indwelling" section of Chapter 2 of this dissertation.

22 This is also found in Chapter 2 of this dissertation in the "ontology of God" section.

${ }^{23} \mathrm{Cf}$. the section in Chapter 2 of this dissertation regarding the relationship between the omnipotence and omnipresence of God. 
John B. Cobb Jr.: Baptism as Participation

Cobb describes baptism in contrast to the substantialist view of a forensic based understanding of baptism in Romans Chapter $6 .{ }^{24}$ Cobb uses process philosophy to construct what he believes is a fuller understanding of what Paul actually meant when describing the effects of baptism upon the believer. This includes the current reality being made up of past occurrences, the mutual-indwelling-participation of the believer with God and the Christ event, and the integration of the believer within the Christian community, which then helps to conform the new believer to a Christ-based life.

Cobb critiques the substantialist view of baptism in Romans Chapter 6 as being too forensic in nature. He believes that the classic theological views of this system are based on the language of justification forensically declared on behalf of the newly baptized believer. ${ }^{25}$ Cobb recognizes that this forensic language is based in Paul's own writings, but he also believes that an exclusive focus on the forensic nature of baptism weakens Paul's more holistic understanding of baptism. ${ }^{26}$ Cobb suggests that Paul's "in Christ" union is discarded by substantialist theology because of the desire to avoid

${ }^{24}$ Whenever Cobb is referred to regarding his comments on Romans it is to be understood that it is both Cobb and Lull that are writing. They did not differentiate from one another when writing their commentary. Cobb and Lull, Romans, 14-15.

${ }^{25}$ Cobb and Lull, Romans, 90-93.

26 “Given Paul's awareness that those who participated in Jesus' faithfulness must constantly struggle against sin, interpreters have often understood his doctrine of baptism in continuity with the forensic view of justification.... Baptism was then understood as the symbolic entry into this new form of life. This may, indeed, be the best way to appropriate this passage today, but it does not capture Paul's own thinking." Cobb describes this further. "Nevertheless, whereas the understanding of Paul in terms of the forensic doctrine of justification has been deeply illuminating of Christian life and has given valuable guidance to the church, the exhaustive translation of Paul's many-sided interpretation of the faithful's relation to Christ in these terms has also impoverished the church. Paul's rhetoric here, and often, was that of participation and indwelling. The faithful were "in Christ" and Christ and the Spirit were 'in' them.... The idea of forensic justification is genuinely Pauline and, therefore, in Protestant circles, it has served as a valuable hermeneutical key. But when all the other genuinely Pauline ideas are reduced to this one, Paul's thought is greatly impoverished." Cobb and Lull, Romans, 90, 92-93. 
mysticism and any type of integration of being. Substantialist theologies insist that the relation between two entities or substances must be external to one another. ${ }^{27}$ In order to fully understand Paul's original meaning, however, Cobb insists that these substantial boundaries need to be set aside.

Cobb believes that the process philosophy of Whitehead brings a possibility for a more complete understanding of Paul's union with Christ in baptism. Rather than the need to express the union in terms of mysticism, one can explain the union as being based upon the process view of reality which is made up of occasions of experience. ${ }^{28}$ As described in Chapter 3 of this dissertation, Cobb's process view of reality is based upon the organization of past occasions of experience which are included within present occasions. Therefore, the past occasions of the Christ event, especially the death and resurrection of Jesus, are actually apart of the current occasion of a believer's baptism. When Paul says that the believer is baptized into Christ's death and raised in his resurrection, the believer is consciously participating in the concurrent reality of the experiential occasions of the original event of Christ dying on the cross and being resurrected from the dead. ${ }^{29}$ Instead of a forensic pronouncement of justification based upon the death of Jesus and a forensic assurance of being resurrected as Jesus was first resurrected, the believer is ontologically participating in the actual past events. Because

27 “Any serious claim of indwelling is taken as 'mysticism' and viewed with suspicion. Those shaped by the dominant, substantialist, conceptuality are compelled to translate all this rhetoric into a language that reflects the mutual externality of all things. The ideal of forensic justification aided and encouraged the translation of the language of mutual internal relations into a language of external relations." Cobb and Lull, Romans, 92-93.

${ }^{28}$ Cobb and Lull, Romans, 93.

${ }^{29}$ Cobb and Lull, Romans, 93. 
the all reality is made up of occasions the occasions of the past literally make up part of the organized reality of the individual believer. Therefore, both God and the human believer are participating in and made up of the same occasions enmeshing their reality/being.

Cobb uses the phrase, "participation in the faithfulness of Jesus," throughout his commentary on Romans, including this section on baptism in Romans $6 .{ }^{30}$ In order to understand what is meant by this, one has to look at his commentary on Romans 1:16-17. Cobb suggests a participationist interpretation of the righteous living by faith. Instead of the righteous having faith in Jesus, as a statement of belief in who Jesus was and what he did, the believer is empowered to participate in the faithfulness of Jesus. ${ }^{31}$ Although Cobb does not describe this participation with the language of the incarnation of the logos within this commentary, the concept can be applied from his other writings. As described in Chapter 3 of this dissertation, Christ is the incarnation of the logos. Every part of creation has the ability to respond to the logos, or primordial will of God, and thus become an incarnation of that logos. Every part of creation, as it responds, can therefore

${ }^{30}$ Cobb and Lull, Romans, 90-94.

${ }^{31}$ Cobb and Lull are careful to strike a position of non-insistence about whether the pistis of Jesus be translated as "faith in Jesus" or "the faithfulness of Jesus," but for their commentary on Romans they chose to use "the faithfulness of Jesus." On the one hand, this translation appears simple enough in terms of their belief that this will encourage a more wholistic life of the believer, with their internal motivations connected with external actions. On the other hand, their use of this translation is a more significant shift from traditional theology, when one realizes that they do not believe that Paul believed Jesus to be divine. Therefore, faith in Jesus has much less significance than participating in the faithfulness of the human being, Jesus, who is indwelling in the same way as all other human beings can be indwelt by the divine. "Paul certainly saw Jesus' faithfulness as unique in its character and especially in its effects, but he also saw a deep continuity between the faithfulness into which all are called and that of Jesus. Through participation in the faithfulness of Jesus, others can share Jesus' status as a child of God. Paul certainly saw God as working in and through Jesus in a unique way, but he knew nothing of a 'divine nature' in Jesus that was not also present in all other human beings. Most theories of Jesus' 'two natures' contradict what Paul wrote in Romans about the continuity of God's dwelling in the faithful and in Jesus. The one and the same Spirit of God, Paul said, dwelt in Jesus and in the faithful." Cobb and Lull, Romans, 36-38. 
be considered Christ to one degree or another. It is true that Cobb clearly states that Jesus is different than the rest of creation because his augmented degree of incarnation is so much more that he becomes a different kind of Christ. ${ }^{32}$ Nevertheless, when a believer participates in the faithfulness of Jesus at his or her baptism, it could be said that they are truly co-constituting their own Christ event. Through the prehension of the occasions of experience the believer is participating in the historical Christ event of Jesus' death and resurrection.

Another concern which Cobb sees in the modern understanding of baptism, compared to that of Paul's original intention, is the lack of affect that the baptism is having upon the new believer. ${ }^{33}$ Some of this he attributes to the lack of understanding concerning the actual union with Christ. He also, however, points out the difference of the level of integration within the Christian community of Paul's time and the modern Church. Cobb believes that the community of Paul's time was based upon the participation of that community around the particular past occasions of the Christ event. This created a separation between those "conformed" by the Christ events and those still being conformed by the immersive corporate evil outside of the Christian community. ${ }^{34}$

\footnotetext{
${ }^{32}$ As noted before in Chapter 3 of this dissertation, where Cobb explains this matter in the following way: "The distinctiveness of Jesus can be spoken of in terms of Christ. Christ is the incarnate Logos. As such Christ is present in all things. The degree and the kind of Christ's presence varies. The fullest form of that presence is that in which he co-constitutes with the personal past the very selfhood of a person. That would be the paradigm of incarnation. In that case Christ would not simply be present in a person but would be that person. The distinctive structure of Jesus' existence was characterized by personal identity with the immanent Logos. Hence it is a matter of literal truth to affirm the identity of Jesus with Christ. In all things Christ is present. Jesus was Christ." Cobb, Pluralistic Age, 142. Others have suggested that Cobb actually does teach that Jesus is only Christ by degree rather than by kind. In my personal correspondence with Cobb, he defended the position that Jesus is different both in degree and kind and said that he stood up against the difference-by-degree-only position. One scholar's understanding can be found in Integrated Theology. Lewis and Demarest, Integrative Theology, 295-296.

${ }^{33}$ Cobb and Lull, Romans, 94.

34 "To be a part of the church community, however, was to be reshaped by the effectiveness in that
} 
They were not perfect in Paul's time, thus Paul's encouragement for the unity of the body of Christ. But compared to modern times the community effect on the new believer was stronger than it is now. Cobb attributes this to the possibility of multiple contexts having greater influence on the believer now than in Paul's time. ${ }^{35}$

From the beginning of this analysis of Romans 6-8, one can witness Cobb's consistent inclusion of indwelling language. ${ }^{36}$ His critique of substantialist theology is based on the need for a fuller understanding of union with Christ. He calls this union mutual indwelling and it is based upon the process philosophy view of reality. ${ }^{37}$ Every experiential occasion is related to the other, perhaps unconsciously, but still related. God consciously knows all of the occasions and therefore all of the occasions are within God. ${ }^{38}$ Cobb once again expresses the ontological nature of divine-human indwelling in a

community of the particular past events around which it organized its life, which collectively we may call the Christ event. When individual life [is] conformed to the Christ event, it was no longer shaped primarily by the patterns of sin and law that dominated the larger society." Cobb and Lull, Romans, 94-95.

35 "For most of the baptized today, in any case, the church is but one of several influential contexts by which they are shaped. The different demands and influences of these contexts may be left unintegrated. If they are integrated, in most instances the distinctively Christian influence is not the center. Baptism is then, at most, an expression of exposure to the influence of Christ. Even this is significant, but it does not have the character Paul realistically ascribed to baptism in the early church. It does not free one from bondage to sin and law. Romans 6:1-14 was Paul's response to the question, "Should we continue in the sphere of sin that grace may increase?" The answer was that participation in the new order of grace, which means participation in Christ, was inherently in contradiction to continued participation in the old order in which sin ruled. The more fully one participated in the new order, the less one would come under the power of sin." Cobb and Lull, Romans, 99.

${ }^{36}$ Cobb and Lull, Romans, 92-93.

${ }^{37} \mathrm{Cf}$. The section on mutually indwelling in chapter 3 of this dissertation.

38 "God is quite literally in creatures as a contributor to each moment of their experience. Creatures become part of the life of God through God's full knowing of them. God is in creatures, and creatures are in God. From the point of view of those caught up in substance thinking, this whole vision of reality may be called 'mystical.' But it is intended as an account of the most ordinary human experience, as well as of the world of scientific objects. The evidence is that the latter, too, are profoundly interrelated. Although we understand this mutual participation to characterize the world in its everydayness, it does open the way to understanding what is more commonly called 'mystical.' If God is in fact present in everything, then the occasional vivid consciousness of God's presence is understandable." Cobb and Lull, 
panentheistic cosmology. Divine reality/being includes and participates with human reality/being. Baptism in Romans 6 is a mutual indwelling of the believer by participation in the historical Christ event of Jesus' death and resurrection. The conscious participation of a person with particular occasions increases the mutual indwelling with those occasions by degree. Therefore, a believer more fully participates with the Christ events by degree than a non-believer. In view of Cobb's Christology, baptism would also be the incarnation of the logos within the individual, thus the individual believer becomes more identified with Christ by degree. Cobb teaches both divine-human ontological indwelling and ontological transformation. Finally, Cobb emphasizes the union of the individual believer with the community of faith, which is also mutually indwelling with God by their participation with the historical Christ events.

\section{Comparison of Wesley and Cobb}

There are some similarities between the thought of Wesley and Cobb on baptism and yet some striking differences as well. The similarities simply begin with both theologians considering baptism to be a union with Christ in some way. For Wesley, this is the engrafting into Christ and the Christian community. Cobb presents this reality in a non-substantialist view, but also believes that through participation in the Christ event a believer is consciously united with Christ and the community that participates in the Christ event through mutual indwelling. It is interesting to note that both Wesley and Cobb significantly emphasize the Christian community as being part of the baptismal union. Perhaps this is one of the ways one can see Wesley's influence on Cobb.

Romans, 93-94. 
Cobb's insistence on the righteous living by faith, being translated as a participation in the faithfulness of Jesus, is also a reflection of Wesleyan concerns. Cobb states that one of the reasons for this interpretation is to take into account both the internal and external sides of life. ${ }^{39}$ Participation in the faithfulness of Jesus affects both the internal belief systems as well as the external actions of the believer for ontological transformation. These statements are reminiscent of Wesley's teaching concerning the internal tempers and external actions of the believer. ${ }^{40}$ To the ear of the Wesleyan scholar this holistic concern for the life of the believer reverberates in all of the concerns of Wesley. These insinuations of theological connection break down, however, when Cobb's theology is further explained.

The differences between Wesley and Cobb concerning the union, in which baptism is involved, are striking. Cobb's emphasis on the participation in the faithfulness of Jesus is based upon a non-divine view of Jesus. Cobb discounts the evidences of the divinity of Jesus, including the virgin birth, as well as the evidences for his divinity in the Gospel of John. ${ }^{41}$ To participate in the faithfulness of Jesus is therefore following Jesus as the exemplar human who most strongly identified with the logos, thus becoming "the"

\footnotetext{
${ }^{39}$ Cobb and Lull, Romans, 38.
}

${ }^{40}$ John Wesley, Sermons on Serveral Occasions (Oak Harbor, WA: Logos Research Systems, Inc., 1999). Our Lord's Sermon on the Mount: Discourse Four, III. 3. For further reading on the connection between internal and external holiness, see: Wesley, Sermons on Serveral Occasions. Means of Grace, I. 4.; Our Lord's Sermon on the Mount: Discourse Three, 3.; Kenneth J. Collins, John Wesley: A Theological Journey (Nashville, TN: Abingdon Press, 2003). 257.; William Ragsdale Cannon, The Theology of John Wesley, with Special Reference to the Doctrine of Justification (New York, Nashville,: AbingdonCokesbury Press, 1946). 251. Kenneth J. Collins, The Scripture Way of Salvation: The Heart of John Wesley's Theology (Nashville: Abingdon Press, 1997). 115, 164, 167.

${ }^{41}$ Cobb and Lull, Romans, 25, 36-38. 
incarnate Christ by augmented degree ("kind" by the significance of the degree), compared to the rest of humanity.

Wesley on the other hand, taught the divinity of Jesus within his direct comments on baptism, which have been expressed in this chapter. Wesley calls for faith in Christ. This faith in Christ and the atonement of Jesus' death are the effective cause by which baptism has the potential to be the external figure of the washing away of original sin. Jesus' life, death, and resurrection are not simply exemplary, but also substitutional. ${ }^{42}$ The basis of Cobb's understanding of mutual indwelling, expressed as the participation in the faithfulness of a non-divine Jesus as an exemplary human, is in direct contrast to Wesley's faith in the atoning death of the divine Son of God.

Another important point, regarding the contrast brought out in this comparison of Romans Chapter 6, has to do with Cobb's panentheism and Wesley's allowance for the withdrawal of the presence of the Holy Spirit within the soul. Cobb suggests a connection between his understanding of panentheism and Wesley's understanding of the original presence of the Holy Spirit within humanity as the image of God. ${ }^{43}$

\footnotetext{
${ }^{42}$ Wesley made some very strong statements regarding the divinity of Jesus, "I therefore no more deny the righteousness of Christ, than I deny the Godhead of Christ; and a man may full as justly charge me with denying the one as the other. Neither do I deny imputed righteousness: This is another unkind and unjust accusation. I always did, and do still continually, affirm, that the righteousness of Christ is imputed to every believer. But who deny it? Why, all Infidels, whether baptized or unbaptized; all who affirm the glorious gospel of our Lord Jesus Christ to be a cunningly devised fable; all Socinians and Arians; all who deny the supreme Godhead of the Lord that bought them; they, of consequence, deny his divine righteousness, as they suppose him to be a mere creature; and they deny his human righteousness, as imputed to any man, seeing they believe every one is accepted for his own righteousness." Wesley, Lord our Righteousness, 242. Wesley's statements regarding the substitution and propitiation of the death of Jesus are just as strong. Wesley, Justification 55, 57, 63-64.Wesley, J. (1872). The Works of John Wesley, Volume 10 (Third Edition) (313). London: Wesleyan Methodist Book Room. See also the Chapter 2 of this dissertation.

43 "Wesley is clear that grace is not a substance or entity introduced into human beings. It is the power for good. This power is not 'given all at once, as if they had a stock laid up for many years; but from moment to moment.' Furthermore, this power is not a thing at all. It is the Holy Spirit, which is the life of God within human beings. That means that concrete human beings are constituted in part by the presence of God within them. Human beings do not first exist in separation from God and then come into relation
} 
It is true that Wesley does say that humanity was originally created with the divine-human indwelling of the Holy Spirit as the image of God. The point of contrast, however, is that Wesley also teaches that this presence is lost to humanity at the fall. ${ }^{44}$ This contrast is brought to light in Wesley's comments on baptism concerning the infusion of grace upon the soul, which will not be lost unless the presence of the Holy Spirit is quenched by the believer turning away. This demonstrates two things. First, the presence of God and grace has been lost in the soul of the believer and needs to be reestablished through the internal act of the Holy Spirit upon the soul, possibly during the external sign of baptism. Secondly, even this re-establishment of the divine-human indwelling can be lost if the believer quenches the influence of the Holy Spirit. Cobb's suggestion of this initial presence of God as co-constitutional of the human being from the beginning in Wesley's theology does not actually support a panentheistic view of reality.

\section{Evaluation of Wesley and Cobb}

How does Wesley's and Cobb's respective understandings of divine-human indwelling affect their interpretation of Romans Chapter 6 regarding this discussion on union through baptism? It is clear that Wesley's classical view of theology is used to suggest that the union with Christ in the new birth is an act of God upon the soul. This interpretation includes the classical view of the duality of humanity as body and soul and divine-human indwelling as the augmentation of grace upon the soul by which God's

with God. Their very life is already God's presence within them. They exist by virtue of their inclusion of the divine life within them." Cobb, Grace and Responsibility, 40-42, 47, 50-51.

${ }^{44}$ Wesley, Great Privilege, 231, 233. 
reality/being can penetrate the timeless reality/being of the soul in humans.

Cobb uses his process view of reality to offer what he considers to be a fuller understanding of Paul's meaning concerning the union of the believer with Christ in baptism. Cobb's panentheistic system, of all occasions of experience being/reality (including human being/reality) included within God, interprets the baptism of the believer as a mutual indwelling by the participation in the occasions of the historic Christ event. For clarity, this does not mean these events included within God are past events continually or concurrently happening, but rather the present organization of occasions of experience. Past occasions are incorporated within present occasions by the organization of an individual's dominant occasion. ${ }^{45}$

Are either one of these positions a fair interpretation of this passage in Romans 6 according to representative exegetical scholarship? There are several points of representative scholarship on the book of Romans, which can shed some light on this question. Representative scholars do support that Paul is talking about a union with Christ in Romans 6. There are some distinctions given, however, regarding the nature of this union. Most if not all seem to set aside the idea of a mystical interpretation of the union found in the cultic mystery religions of Paul's day. Any connection to these mystery cults has been largely rejected by representative scholarship. ${ }^{46}$ Instead, scholars point to Paul's

\footnotetext{
${ }^{45}$ For more on this please refer to the section on the ontology of humanity in Chapter 3 of this dissertation, specifically regarding the dominant occasion.

46 Douglas J. Moo, Romans 1-8, The Wycliffe exegetical commentary. (Chicago: Moody Press, 1991), 395; James D. G. Dunn, Romans 1-8, Word Biblical Commentary, vol. 38A (Dallas, TX: Word Incorporated, 1988), 327-330; Joseph A. S.J. Fitzmyer, Romans: A New Translation with Introduction and Commentary, Anchor Yale Bible vol. 33 (New Haven; London: Yale University Press, 2008), 431; Richard N. Longenecker, The Epistle to the Romans: A Commentary on the Greek Text, The New International Greek Testament Commentary (Grand Rapids, MI: Eerdmans, 2016), 693-694.
} 
speaking from the Christian tradition itself, referencing John the Baptist's words

regarding water and spirit baptism and, perhaps more directly connected, Jesus' own

words about his death being a baptism he must go through. ${ }^{47}$

It seems the mystery cultic mystical union has been the basis for some

interpretations of an ontological merging of human reality/being with divine

reality/being, which is Christ. ${ }^{48}$ Because representative scholarship moves away from the mystery cults to a more primary source for Paul found in John the Baptist or Jesus' own

words, this may create a challenge for an ontological nature for the union. ${ }^{49}$ The challenge becomes stronger when the description of the union by these scholars is one of representative, forensic, and moral union, which will be discussed a little later. Wesley's dualistic ontological union with the soul and Cobb's panentheistic union may both be

${ }^{47}$ Dunn also connects Jesus speaking about his death as a baptism with Paul's teaching on the union with Christ being related with Baptism. "The association of baptism and death is probably distinctively Christian. Jesus himself was remembered as having made the link (Mark 10:38-39; Luke 12:50), that is, explicitly using baptism as a metaphor for his own death, the imagery of death as an

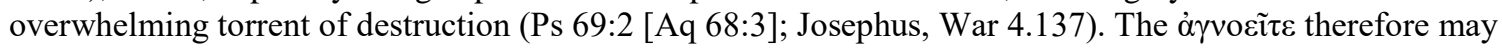
refer implicitly to this tradition as something the Roman believers should know: Paul speaks of their being baptized to share Jesus' death because Jesus had spoken of his own death as a "baptism" (cf. Cullmann, Baptism, 19-20; Robinson, Wrestling, 69; other bibliography in Halter, 530 n.25). If the Baptist had spoken of a baptism which all must undergo, and Jesus was remembered as having focused that baptism on himself, then Paul here combines the two: all must be baptized with his baptism (see further Dunn, "Birth of a Metaphor"). Alternatively, or in addition, the new step Paul takes here is that of combining two strands of his own teaching which he had not hitherto linked - baptized into (union with) Christ (as in Gal 3:27 and 1 Cor 12:13), and dying with Christ (as in Gal 2:20 and 2 Cor 4:10-11). Whatever knowledge of these traditions Paul could assume on the part of his readers, he certainly points back to the Adam/Christ contrast of 5:12-21; they have died to $\sin (\mathrm{v} 2)$ because they have died with Christ and because Christ now lives beyond sin and death, a life which they can share (cf. particularly Schnackenburg, 'Voraussetzung')." Dunn, Romans, 311-313. See also: Fitzmyer, Romans, 431.

${ }^{48}$ To see which interpretations did affirm a mystical union reference the citations listed in footnote 46 of this chapter.

${ }^{49}$ While there may be other options for ontological union besides mystic-mystery religions, this was the only option explicitly mentioned by the representative scholars in direct relationship to this passage of Scripture. 
challenged by representative exegetical scholarship moving away from the concept of an ontological union. ${ }^{50}$

Another move away from both the mystical and the sacramental union is the emphasis on the historical-salvation events of Christ's life, death, and resurrection as the basis of the union, rather than the action of baptism. ${ }^{51}$ Both Cobb and Wesley point in this direction as well. Cobb's occasions of experience point to the historic events and Wesley's emphasis that the new birth or conversion experience is more significant than the act of baptism itself, based on faith in what Christ had done also points to these historical-salvation events. There are some differences, however, with representative scholarship.

${ }^{50}$ While there may be other ontological options for the union of the believer through baptism, the classical-transcendent-sacramental model or the immanent-panentheistic models are the two general categories for the other options. Either a timeless-eternal God is uniting himself with the timeless-immortal part of the human being, the soul, or God is merged with all of the cosmos to various degrees from panentheism to pantheism. Even if there are other options, these are the two options that are represented within this dissertation and therefore the ones which will receive evaluation by means of the representative scholars.

51 "First, it is clear that Paul refers in vv. 3-4 to water baptism; but baptism is not the theme of the paragraph nor is it Paul's purpose to exposit his theology of baptism. Baptism, rather, functions as shorthand for the conversion experience as a whole. As such, it is the instrument (note the 'through' in v. 4) by which we are put into relationship with the death and burial of Christ. It is not, then, that baptism is a symbol of dying and rising with Christ; nor is it that baptism is the place at which we die and rise with Christ. Dying and rising with Christ refers to the participation of the believer in the redemptive events themselves; and the ultimate basis for Paul's appeal in this chapter is not what happened when we were baptized, but what happened when Christ died and rose again." Moo, Romans, 355. Citing Moo, Schreiner makes the same point in reference to baptism as a sacrament, "A sacramental understanding is flawed because it emphasizes baptism rather than the historic and definitive death and resurrection of Christ (cf. Moo 1991: 380-81). Paul's main concern in this text is not baptism; it is never mentioned again after verse 4. What animates the discussion is the significance of Christ's death and resurrection for believers." Thomas R. Schreiner, Romans, Baker Exegetical Commentary on the New Testament, vol. 6 (Grand Rapids, MI: Baker Books, 1998), 309-310. When speaking about the believer being baptized in the likeness of Christ's death, Dunn thinks it very odd to say that the believer would somehow participate in the historical event of Christ's death. There must be some distinction from the historical event itself. This seems to be a direct counterpoint to the process idea of participation in the actual historical events. It also seems to be a statement against the sacramental view of the believer participating in a Christ event in the eternal now or the repeated sacrifice of Christ in the Eucharist. Dunn, Romans, 330. It is possible that the participation that Moo, Shreiner, and Dunn are advocating for is one of a symbolic recollection rather than a merging of reality or being either sacramentally or panentheistically. 
The death and resurrection of Christ serve two primary purposes. The first is the representative nature of Christ as the second Adam. Just as all of humanity was incorporated under the representation of Adam, so all Christian believers are incorporated within the representation of Christ in his death on the Cross. ${ }^{52}$ Understanding Christ as the new representative for humanity, scholarship would not be pointing to an ontological merging of being with Christ. Adam is long since dead so those who are still under the representation of Adam because they have not accepted Christ cannot be united with Adam in reality/being. Therefore, it would not make sense to say that humanity was ontologically united with the being of Christ as their representative. ${ }^{53}$

The second purpose is in line with the first and it is expressed in the concept of two different ages. The old age was the age under the reign of sin and death. This is the age of Adamic representation and the "old man" of a Christian's life. The new age is an age that is separated from the reign of sin as a power and its consequence, i.e. death. This is the age of Christ's representation and the "new man" of the Christian experience. ${ }^{54}$ The transference to the status of a new man, may be an indication of an ontological transformation of the believer. Although the context of rejecting the reign of sin and death seems to have more to do with a moral shift than the transformation of one's being.

In Romans 6, Paul teaches that Christians have died to sin with Christ and will be

${ }^{52}$ Schreiner, Romans, 307-308, 320; Moo, Romans, 394-395, 381; Dunn, Romans, 327-329.

${ }^{53}$ Both Adam and Jesus Christ were fully human (Adam through creation and Jesus through incarnation) so in that sense they were ontologically human. And in Christ there is a unique union of humanity and divinity, which has been defined as two natures in one person. This, however, does not unite other human beings with the divine in the same way that Jesus was united. John Cobb would argue for this, but Christ as our representative argues for a forensic understanding rather than an ontological one. A full understanding of the divine-human union within the incarnation is beyond the scope of this dissertation.

${ }^{54}$ Schreiner, Romans, 307-308. Moo, Romans, 374; Dunn, Romans, 327-329. 
raised to life with Christ. Representative scholarship understands this as a transfer from one age to another, or from one sphere of rulership to another. The first age is within the sphere or rulership of sin and death and the second age is within the sphere or the rulership of Christ. ${ }^{55}$ The new sphere is only partially realized as demonstrated by Paul's use of the future tense for the believer's resurrection with Christ. This is recognized as the eschatological tension of the now and not yet. According to commentators, Paul is teaching a future resurrection, not only in Romans Chapter 6, but in his other letters as well. There is a strong theology of an assured eschatology, which is so certain that scholars are describing it as already breaking through, but not yet realized. ${ }^{56}$

This tension offers some difficulties for Cobb. Process theology does not hold to a certainty of the traditional eschaton because of the desire to present God as persuasive rather than coercive. Cobb does recognize a tension between the primordial will of God and the consequential will of God, which is the process of all creation as God lures it forward. An additional problem for Cobb is more in the nature of the union that this language of representation and two ages suggests. Cobb claims that he is presenting a

55 "While, however, it is true that Christ did not need to be freed from sin the same way that we need to be, a close parallel between the experience of Christ and of the Christian can be maintained if we remember that Paul is continuing to speak of sin as a 'ruling Power.' Just as death once had 'authority' over Christ because of his full identification with sinful people in the 'old age,' so that other ruling power of the old age, sin, could be said to have had 'authority' over Christ. As a 'man of the old age,' he was subject to the power of sin — with the critical difference that he never succumbed to its power and actually sinned. When these salvation-historical perspectives are given their due place, we are able to give 'die to sin' the same meaning here as it had in v. 2: a separation or freedom from the rule of sin." Moo contends that this issue of lordship is a keynote to understanding Romans 6. Moo, Romans, 379, 387. Dunn speaks of the ages as two different dominions. Dunn, Romans, 307-308, 318-320, 323. See also: Longenecker, Romans, 617. Fitzmyer, Romans, 431; Schreiner, Romans, 317. The ages as dominion focus on the moral accent to the rulership of sin or of righteousness in one's life. This is demonstrated in Romans 7, when believers are called to offer their members and instruments of righteousness rather than sin.

${ }^{56}$ Longenecker, Romans, 615-617; Schreiner, Romans, 312, 317; Dunn, Romans, 307-308, 311$313,318-319$. 
fuller understanding of Paul's meaning in Romans. But according to representative scholarship the mystical/ontological union has been dismissed in preference for a forensic representative or moral union. The recognition of participation is present in representative scholarship but it also remains as an emphasis on participation as forensic, moral, relational, and rulership, differentiated from the ontological blending of divine-human being/reality. ${ }^{57}$ Cobb would most likely dismiss this as interpretations from a substantialist worldview. The problem is the evidence being presented by the substantialist understanding seems to be more in line with the exegetical evidences regarding Paul's probable meaning. ${ }^{58}$ Would Cobb have come to the same explanation of Paul's fuller meaning by exegetical evidence that does not require the Whiteheadian filter? This does not appear to be the case and Cobb would not claim this himself, as he

\footnotetext{
57 "Of course, we must remember what this death means. This is no more a physical, or ontological, death than is our burial with Christ (v. 4) or our "dying to sin" (v. 2). Paul's language throughout is forensic, or positional; by God's act, we have been placed in a new position....But the assumption that 'old man' and 'new man' refer to parts, or natures, of a person is incorrect. Rather, they designate the person as a whole, considered in relation to the corporate structure to which he or she belongs. 'Old man' and 'new man' are not, then, ontological, but relational or positional in orientation. They do not, at least in the first place, speak of a change in nature, but of a change in relationship.... A second caution has to do with the nature of this union with Christ. Even though it has been popular to call this union a 'mystical' one, this language is best avoided as suggesting an ontological or natural union. In the case of both Adam and Christ, the union between them and those whom they represent is primarily and in Christ's case perhaps exclusively - forensic. Because he is our representative, the judgment or decision that has fallen on Christ falls also on those who come to belong to him. Seen in this light, the 'participationist' language of Paul is at the service of, and determined by, his forensic or 'judicial' conception of the work of Christ. There is no conflict between these two Pauline conceptions. We must also avoid absolutizing any one of Paul's many ways of conceiving our relationship to Christ: for example, 'we in Christ,' 'Christ in us,' and 'Christ for us.' Each of these says something important about what God has done for us in Christ and how he has done it, but none should be taken ontologically." Moo, Romans, 373, 395. I am leaning towards an agreement with these scholars regarding the nature of the union with Christ. It does not make sense for the representative understanding of Christ to be an ontological one. It is also important to be careful about suggesting that the believer is made righteous when they become the new man, moving from one age to the next. If baptism is the beginning of the new birth it is more representative of justification than sanctification. The imputation of righteousness rather than the impartation of righteousness is essential for the eschatological tension that Paul describes between the two ages.

${ }^{58}$ As mentioned before Cobb and Lull are committed to building on historical critical scholarship and staying close to the text rather than simply writing essays on chosen topics within their commentary. Therefore, they are still open to the critical discussion of other exegetical scholars.
} 
readily positions Whitehead as his prominent interpretive lens.

Representative scholarship has some challenges for Wesley and classical theism

as well. The future resurrection spoken of in Romans Chapter 6 is seen as a bodily

resurrection. This is not a problem for Wesley, as he also sees the eschatological

resurrection involving a new body. There has, however, been some greater emphasis put

on the body (Greek soma) in Romans 6 as the whole person. This definition of the whole

person includes emotional, social, spiritual, and physical aspects of the person. ${ }^{59}$ Wesley

has emphasized the importance and integration of the soul with the body, but he has

continued to hold to a body/soul dualism. ${ }^{60}$ This is the basis of the classical

understanding of divine-human indwelling. If the body and soul are not dualistic but

rather holistic in Paul's understanding, what does this mean for divine-human indwelling

in the soul? More importantly, the problems of the non-ontological nature of the union of

Christ already brought out in this section. If the union with Christ is representative,

relational, and based on the sphere of rulership in nature, rather than ontological, this

creates challenges for Wesley as well as Cobb. ${ }^{61}$

\footnotetext{
${ }^{59}$ Most of the discussion here surrounds the term "soma" used by Paul to describe the person including the physical body. This includes offering the members of the soma to righteousness as well as the recognition of the biblical understanding of the person as holistic rather than the dualistic Greek understanding of body and soul. While scholars like Schreiner, Moo, and Dunn would not accept a fully holistic view of human ontology in their theological systems and they emphasize the importance of embodiment only for this age, they do recognize that Paul thinks Hebraically of the whole person, especially in regards to this passage. Schreiner, Romans, 323; Moo, Romans, 383; Dunn, Romans, 319-320. "This is all to state that Paul's thought is characteristically Hebraic and only occasionally gives ground, wittingly or unwittingly, to a more typically hellenistic dualism between soul and body, body being separable from the real "me." Dunn, Romans, 320.

${ }^{60} \mathrm{Cf}$. the section of Chapter 2 of this dissertation regarding Wesley's understanding of human ontology. Even if representative scholarship supports a dualistic theological anthropology in their own theological system. The recognition of the lack of this kind of theological anthropology within Paul still creates a challenge for Wesley and for the other scholars as well.

${ }^{61} \mathrm{I}$ am interested in the further canonical study to better understand the ontological nature of divine-human indwelling. I do think it is more biblically accurate to move away from the ontological enmeshment of the divine and human realities/beings. It is encouraging for me to find this same reasoning
} 
It is interesting to note, however, that a more holistic view of humanity is not a problem for Cobb. In his comments on Chapter 7 of Romans, Cobb gives evidence to suggest that Paul is not speaking of a dualism when he is writing of the flesh and of the spirit. ${ }^{62}$ For Cobb, Paul in no way would remove the body from the transformation process of the baptized believer, as if it did not also play a part for the body. Cobb's selftranscending spirit for human ontology is not separate from the body, but rather an objective consciousness that takes responsibility for the rest of the person. The soma as presented by the representative scholars has no challenges for Cobb.

Wesley also has some support and some opposition regarding the imagery of engrafting as union with Christ. ${ }^{63}$ Some scholars suggest that this would better be understood as biological rather that horticultural. The literal interpretation is that of a wound healing and closing up or bone knitting with bone. The theological meaning points to a concept of growing together. It does not seem, however, that this discussion presents a substantial challenge to Wesley's understanding of divine-human indwelling. He would simply need to change his metaphor from horticultural to biological.

A final question for both Cobb and Wesley is the lack of emphasis regarding a union with the body of Christ as the church specifically within Romans Chapter 6. Some

in the representative scholarship for this study. Drawing conclusions on the interpersonal nature of divinehuman indwelling is beyond the scope of this dissertation and requires a full canonical study. This study does however point towards a possible direction for further study. I will speak more about the possible implications for this in Chapter 5.

${ }^{62}$ Cobb and Lull, Romans, 106.

${ }^{63}$ Scholarship does not point towards an ontological nature to the union of this metaphor, even if it is compared with the healing of the physical body. It is still in the language of metaphor not ontological reality. Schreiner and Dunn support a biological view while Fitzmyer holds to a horticultural view. Schreiner, Romans, 313; Dunn, Romans, 316; Fitzmyer, Romans, 435. 
scholars point out that Paul's emphasis in this chapter of Romans is on the believer's union with Christ and does not mention a union with the corporate community. The incorporation in Christ as representative may suggest this, but it is not really mentioned in this particular passage. ${ }^{64}$ Scholars do recognize the union of the believer with the Christian community in later passages of Romans.

Through this brief scriptural analysis, one can recognize that there are similarities and differences between Wesley's and Cobb's interpretation of Romans Chapter 6 with representative scholarship. The emphasis on the historical-salvation events and discussion of some sort of union with Christ are present in all of them. The nature of the union in representative scholarship, however, poses a problem for both Wesley and Cobb. The tendency away from an ontological union in representative scholarship would not allow for either Wesley's classical-theistic divine-human indwelling within the soul nor Cobb's panentheistic participation in the being of God via the occasions of experience. Given these challenges of interpretation, what understanding of divine-human indwelling does representative scholarship support? Is union with Christ something different from divinehuman indwelling? These possible implications will be more fully engaged in Chapter 5 of this dissertation, but for now, there is more to learn from Romans Chapter $8 .{ }^{65}$

${ }^{64}$ Schreiner, Romans, 308. Once again the representative understanding of union with Christ whether corporate or individual does not suggest an ontological union of divine-human reality/being.

${ }^{65}$ Romans Chapter 7 does speak of indwelling sin, which is an interesting comparison when one is considering the indwelling of the Spirit. Neither Cobb nor Wesley deal with this in their writing in any significant way. The more substantial portions of Scripture for the comparison of these two theologians are found in Chapter 8. For this reason, this dissertation will not take the time to engage Romans Chapter 7. 


\title{
Romans Chapter 8:1-17-Life in the Spirit
}

\author{
Introduction
}

There are several key issues regarding the nature of divine-human indwelling in Romans 8:1-17. In this is the passage, Paul uses the language of indwelling directly, and, therefore, this is a helpful passage in this comparison of Wesley and Cobb. Wesley focuses on a life that is directed by the Holy Spirit as the instrumental agent who acts upon the human soul. Cobb, once again using a non-substantialist worldview, speaks of mutual indwelling through participation in the constitution of being. Wesley and Cobb's positions will be outlined separately, compared, and then analyzed by a brief survey of representative scholarship on this passage.

Wesley: A Life Directed by the Holy Spirit

For Wesley, the life in the Spirit described in the first part of Romans Chapter 8 has primarily to do with a life that is guided or directed by the Holy Spirit. This is true of the internal thoughts and words of the believer, as well as the external actions of the believer. ${ }^{66}$ According to Wesley, both the internal direction of the Spirit as well as the external cleansing of the believer resonate with the opening phrase of Romans 8:1, relieving the believer from condemnation. The believer is cleansed from the condemnation of external sinful actions by the propitiatory sacrifice of Jesus and through

66 " 4 . That the righteousness of the law-The holiness it required, described, ver. 5-11 might be fulfilled in us, who walk not after the flesh, but after the spirit-Who are guided in all our thoughts, words, and actions, not by corrupt nature, but by the Spirit of God. From this place, St. Paul describes primarily the state of believers, and that of unbelievers, only to illustrate this. 5. They that are after the flesh-Who remain under the guidance of corrupt nature; mind the things of the flesh-Have their thoughts and affections fixed on such things as gratify corrupt nature; namely on things visible and temporal; on things of the earth, on pleasure, (of sense or imagination) praise, or riches. But they who are after the Spirit-Who are under his guidance, mind the things of the Spirit - Think of, relish, love things invisible, eternal; the things which the Spirit hath revealed, which he works in us, moves us to, and promises to give us." Wesley, Explanatory Notes on NT, 393. Wesley, First Fruits, 87. Wesley, Farther Appeal, 101. 
his shed blood. ${ }^{67}$ The internal condemnation is something that is dealt with by the work of the Holy Spirit within the soul which removes the condemnation of the internal process of the sinful mind and heart, which are at enmity with God ${ }^{68}$ The mind of the believer is no longer on the things of the flesh or ruled by the desires or government of the flesh. Instead, through the governance of the Spirit, the mind of the believer experiences life and the resulting peace, which is a "foretaste of life-everlasting." 69

Much of Wesley's time spent interacting with Roman's Chapter 8 has to do with his defense against others' accusations of enthusiasm against him. ${ }^{70}$ Wesley argues that the internal guidance and direction of the Holy Spirit is an ordinary gift for all believers evidenced by the resulting peace in the mind, opposed to enmity in the mind of unbeliever. ${ }^{71}$ This is not, Wesley defends, a supernatural direction or guidance suggesting a supernatural enthusiasm. Paul's teaching regarding the testimony of the Spirit to the human spirit results in a reassuring peace by which believers can be assured that they are children of God and have been sealed by the Spirit of God. ${ }^{72}$ Wesley points to the use of both the Greek and the Syriac term for the believer to "cry out" Abba father to suggest

${ }^{67}$ Wesley, First Fruits, 89-90; Wesley, Repentance of Believers, 163-164.

${ }^{68}$ Wesley, First Fruits, 89-90.

${ }^{69}$ Wesley, Explanatory Notes on NT, 394.

${ }^{70}$ A large section of Wesley's "Farther Appeal to Men of Reason: Part I" is dedicated to defending himself against the accusations of enthusiasm that had been brought against him. Wesley argues by using the works of Chrysostom and Origen, as well as other Bishops in his defense. Wesley, Farther Appeal, 85$87,105$.

${ }^{71}$ Wesley, Explanatory Notes on NT, 393; John Wesley, The Doctrine of Original Sin According to Scripture, Reason, and Experience: Part II, Third ed., The Works of John Wesley, vol. 9 (London: Wesleyan Methodist Bookroom, 1872), 271-272. 101.

${ }^{72}$ Wesley, Spiritual Christianity, 39; Wesley, Witness of the Spirit, 125; Wesley, Farther Appeal, 
that Paul is teaching that this gift of the Spirit is for both Jew and Gentile in an attempt to bring all believers together in a "joint cry."73

Wesley also specifies that the guidance or direction of the Spirit is possible because of the inward impression of the Spirit upon the soul of the believer. ${ }^{74} \mathrm{He}$ also makes a direct tie between one being in Christ and the indwelling of the Spirit, for where the Spirit of Christ is, Christ is also there. ${ }^{75}$ The primary emphasis for Wesley in the beginning of Romans Chapter 8, regarding walking according to the Spirit, is to recognize the guidance and direction of the Spirit upon the words, thoughts and actions of every believer and will be evidenced by a resulting peace in the mind of each believer.

\section{Cobb: Mutual Participation in Being}

Cobb's interpretation of Romans 8:1-17 begins with his work on the law of sin and death versus the law of the Spirit. Cobb comes to the conclusion that one should not understand this to say that Paul is calling those who are now a part of the life in the Spirit to also be under the obligations of the law. Rather than there being a nomos for the Jews and a nomos for the Gentiles, there is instead a new way of life, which is the nomos of the Spirit. This new way of life is set in distinction from the way of the flesh and is for both the Jew and the Gentile. ${ }^{76}$ Cobb uses the language of the sphere of the flesh and the

\footnotetext{
${ }^{73}$ In his comments of Romans 8:15. Wesley, Explanatory Notes of NT, 394.

${ }^{74}$ Wesley, The Witness of the Spirit, 125.

${ }^{75}$ Wesley, Explanatory Notes of NT, 394.

${ }^{76}$ Cobb and Lull, Romans, 115.
} 
sphere of the Spirit. The sphere of influence or rule has changed from that of sin and death to that of the Spirit and of life. ${ }^{77}$

Cobb then asks how this transition has taken place and answers the question by saying that it has happened through Christ. ${ }^{78}$ Christ is the new organizing principle of the sphere of the Spirit. Cobb believes that Paul makes no distinction between the Spirit and Christ. ${ }^{79}$ A believer can be in Christ and in the Spirit, the believer can have Christ in him and the Spirit in him. Although Cobb does not state it in his commentary on Romans, these ideas are clearly connected to Cobb's teaching on the logos or the primordial will of God. The logos is the organizing principle of God as his intentional will of how the cosmos should be shaped. The possible description of the Holy Spirit in Cobb's theology is the consequential fulfillment of the primordial will. Therefore, Christ and the Spirit are two expressions of the will of God, and one expresses the intention of God and the other expresses the realization of that intention. ${ }^{80}$

Cobb does, however, point to a very clear distinction between the Spirit and the human spirit. Cobb believes that Paul rejects any sort of possessive displacement of the human spirit by the Holy Spirit indwelling a person and enabling that person to call out,

${ }^{77}$ Cobb and Lull, Romans, 116-117.

${ }^{78}$ Cobb and Lull, Romans, 116-117.

79 "One would be hard pressed to distinguish the presence of Christ in the baptized from the presence of the Spirit. The distinctions that became so important in the later Trinitarian and Christological controversies were absent from Paul's mind and concern, and his language cannot be made to conform to them. Although his formulations tended at times to treat the Spirit as a separate being, it probably never occurred to him that the Spirit was a divine Person distinct from the risen Jesus (or Jesus as the Incarnate Logos or Word) and from God.” Cobb and Lull, Romans, 117.

${ }^{80}$ See the section on Cobb's Trinity of wills in Chapter 3 of this dissertation. 
Abba Father. ${ }^{81}$ For Cobb, the testimony of the Spirit to the spirit of the person is an internal process of assurance by which the Spirit assures the spirit of the person that they are accepted as a child of God..$^{82}$

Cobb describes this experience of the Spirit indwelling a human being and making them a child of God as the same experience of Jesus being indwelt by the Spirit of God and thus being the son of God. ${ }^{83}$ According to Cobb, Paul never actually calls Jesus divine. ${ }^{84}$ Cobb pushes Paul in the other direction, suggesting that Paul's statement of Jesus becoming like sinful flesh points to the fallen condition of Jesus' humanity rather than holding on to some vestige of divinity. ${ }^{85}$ Christ and the Spirit are not distinguished from one another in Cobb's interpretation, but Jesus as the Christ is only possible through the indwelling of the Spirit/Christ. This once again reminds one of Cobb's previously stated stance on Jesus as the human being most in line with the logos so that he is called the Christ. ${ }^{86}$ One could say that, for Cobb, Jesus is the one who most clearly walked according to the Spirit and lived within the sphere of Christ as the organizing principle of the new Christian life.

Cobb describes the ontological nature of this union of Jesus and humanity with the Spirit in the terms of a non-substantial reality once again. The process view of every

\footnotetext{
${ }^{81}$ Cobb and Lull, Romans, 118.

${ }^{82}$ Cobb and Lull, Romans, 118.

${ }^{83}$ Cobb and Lull, Romans, 120.

${ }^{84}$ Cobb and Lull, Romans, 119-120.

${ }^{85}$ Cobb and Lull, Romans, 116-117.

${ }^{86}$ See the discussion of logos in Chapter 3 of this dissertation.
} 
occasion of experience being constituted by previous occasions and constituting part of future occasions allows for humanity to mutually indwell Christ and the Spirit. ${ }^{87}$ Once again, Cobb says that Paul makes no ontological or personal distinction between Christ and the Spirit. ${ }^{88}$ He believes that this is a later development in the Trinitarian controversy of the early church. The individual person can mutually indwell the Spirit and Christ through participation and co-constitution of being. The primordial will of God, Christ, can be accepted and constitute part of the being of the believer, which in turn will be a fulfillment of the consequential will of God, the Spirit. Once again, according to Cobb, all of creation including the non-believer participates in the co-constitution of being. But the conscious acceptance of the primordial will of God by the believer participates in the consequential will to a greater degree.

\section{Comparison of Wesley and Cobb}

Both Cobb and Wesley suggest that the rule, governance, guidance, sphere, and nomos of the Spirit be compared to the rule of the flesh. They both consider it to be important that to walk according to the Spirit means to have a ruling influence of the Spirit. Both Wesley and Cobb also connect the indwelling of the Spirit to the presence of Christ. Wesley's defense against enthusiasm is done by making the gift of the Spirit's guidance and direction in the internal and external life of the believer a general gift which is a part of all believer's Christian experience. This is similar to Cobb's suggestion that indwelling is generally available to all who would respond to the new organizing

\footnotetext{
${ }^{87}$ Cobb and Lull, Romans, 119.
}

88 "As we noted Paul could use virtually the same language about the relationship to Jesus Christ and to the Spirit. This Spirit indwelt the faithful, and the faithful also indwelt the Spirit, just as Christ was in them and they were in Christ." Cobb and Lull, Romans, 118-119. 
principle of life. Wesley and Cobb also both affirm that the testimony of the Spirit to the human spirit is given in an experience of assurance to the believer. The Spirit is differentiated from the human spirit as one testifies to the other. Wesley wrote that the Spirit acts upon the soul, making the Spirit an active agent in this process, which would then be separate from the human spirit. Wesley speaks of the assurance of the testimony of the Spirit resulting in a taste of everlasting peace. This is similar to Cobb's teaching concerning the Holy Spirit as the peace or kingdom of God. ${ }^{89}$

There are significant differences here as well. Wesley treats the Holy Spirit as an active agent who moves upon the soul in order to cleanse it from condemnation and assure the believer that he or she is a child of God. Cobb, on the other hand, blends the Spirit and Christ into an organizing principle, or the primordial and consequent natures of God. This lessens the personal nature of the agent of the Holy Spirit. Cobb suggest that the Spirit is nothing more than either the resulting peace or kingdom of God or the consequent nature of God being reintroduced to the possibility of prehension as the fourth phase of Whitehead's cosmic cycle. Wesley on the other hand portrays the Spirit as the efficient cause which produces the peace felt in the soul of the believer.

Another of the key differences is once again based on Christology. Wesley continues to speak of the role of Jesus Christ as the propitiatory sacrifice which removes the condemnation for the external sinful acts of the sinner. Cobb instead makes the man Jesus a respondent to "Christ," the primordial will of God. The believer finds peace and relief by participating in the faithfulness of Jesus. In other words, they respond to

${ }^{89}$ See Chapter 3 of this dissertation. 
"Christ" the same way that Jesus did and they are made to be children of God in the same way that Jesus was.

There are bridges between the theology of Wesley and Cobb. There are glimmers of Cobb's Wesleyan roots shining through in their points of general agreement concerning the walking in the Spirit being related to the governance, rule, or sphere of the Spirit. The ways in which the individual humans respond and interact with the Spirit in these two scenarios, however, have distinct differences. Once again, Cobb's panentheistic worldview and dependence on Whitehead's philosophy reshape the way in which this interaction is interpreted. The ontological nature of divine-human indwelling presented by Wesley is an example of classical theology, in which the Spirit acts upon the soul of the individual. In contrast, Cobb's view is clearly panentheistic through the participatory co-constitution of divine-cosmic mutual indwelling.

\section{Evaluation of Wesley and Cobb}

How does representative biblical scholarship interact with the interpretation of Paul's words in Romans 8:1-17 and what does this reveal regarding Wesley and Cobb's interpretations? It seems best to work through the order of the text and the comments of representative scholarship as one seeks to address the interpretations of Wesley and Cobb. Starting with the beginning of Romans Chapter 8, the first verse deals with the condemnation concern of Wesley. Most representative scholarship seems to be in agreement with Wesley, that those who are in Christ Jesus are being freed from condemnation and that this has to do with the atoning sacrifice of Christ as the sin offering. Especially when tied with the following verses, the Son has been sent in the 
likeness of sinful flesh to be a sin offering, which condemns the flesh. ${ }^{90}$ This is not a condemnation of the ontological flesh, as opposed to the ontological spirit, but rather the sin sacrifice ushers believers from the old epoch, age, and or realm of the sin and death, represented by the flesh, into the new age, sphere, or realm of the Spirit. ${ }^{91}$

In addition to the agreement with Wesley concerning the atoning work of Christ, many scholars suggest that the sending of the son also has, at the very least, insinuations of the pre-existent relationship of the Son with the Father. ${ }^{92}$ There is a tendency in

${ }^{90}$ Moo adds the breaking of the power of sin to the atoning nature of Christ's death. "The interpretation that best meets the criteria above sees the condemnation of sin to consist in God's executing his wrath on sin in the atoning death of his Son. As our substitute, Christ 'was made sin for us' (2 Cor 5:21) and suffered the wrath of God, the judgment of God upon that sin (cf. hilasterion in Rom 3:25; Gal 3:13). In his doing so, of course, we may say that sin's power was broken, in the sense that Paul pictures sin as a power that holds people in its clutches and brings condemnation to them. In executing the full sentence of condemnation against sin, God effectively removed sin's ability to "dictate terms" for those who are "in Christ' (v. 2). The condemnation that our sins deserve has been poured out on Christ, our sin-bearer; that is why 'there is now no condemnation for those who are in Christ Jesus'" Moo, Romans, 481, 472-473. Schreiner seems to be in agreement with Moo when he adds both the forensic nature of the death to the overturning of the dominion of sin. Schreiner, Romans, 399. Dunn, while considering objections to the current sensitivities to Paul's use of sacrificial language, demonstrates the very natural use of the language by Paul in the first century. "But such a sacrificial allusion would be wholly natural and unremarkable in a first-century context. Paul can merely allude to it since this way of thinking of Jesus' death was already well established in the Christian congregations (as the pre-Pauline formula in 3:25-26 implies; see 3:21-26 The theology is fairly clear: the death of the sin offering effects God's condemnation of sin (see below in the next clause) by the destruction of the sinful flesh; the only remedy for flesh's incorrigible weakness in the hands of $\sin$ is its death (see further on 3:25). Here it functions as part of Paul's Adam Christology: Christ's death, in its identity with sinful flesh, breaks the power of sin by destroying its base in the flesh (the new humanity beyond death is not of flesh, and so also is not under sin)." Dunn, Romans, 422.

${ }^{91}$ Earnest Kasemann, Commentary on Romans, trans., Geoffrey W. Bromiley (Grand Rapids, MI: William B. Eerdmans Publishing Company, 1980), 222-223; Moo, Romans, 477, 485; Schreiner, Romans, 413; Dunn, Romans, 415-416. This transition from the old age to the new age is a transition of rulership and moral surrender rather than some sort of ontological union with Christ. As mentioned in the previous section of this chapter the new age is the age in which Christ is the forensic representative of humanity. It is true that in Christ the divine humanity were united, but this is unique to Jesus Christ according to classical theology and the representative scholarship recognizing the divinity of Jesus and his substitutionary atonement rather than the process non-substantial participation in the faithfulness of Christ.

92 Fitzmyer is in full support of seeing the preexistent nature of the Father/Son relationship. "The emphatic phrase 'his own Son' is stronger than 'Son of God' and highlights the divine relationship of Jesus to the Father and the divine origin of the task to be accomplished by one in close filial relationship with God. Implied in this is the unique bond of love between the two that is the source of human justification and salvation. Also implied is the preexistence of Jesus as Son, as in 1:3; Phil 2:5; and Gal 4:4." Fitzmyer, Romans, 484-485. Schreiner acknowledges that some scholars, including Kasemann, see an interpretation that includes the preexistence of the son of God as including classical material; but he still states that "the expression implies the preexistence of the Son," in agreement with other scholars. Schreiner, Romans, 402. 
representative scholarship to recognize some suggestion of the divinity of Christ in Romans 8 itself and an even clearer recognition when combined with Paul's words in Philippians Chapter 2. ${ }^{93}$ Cobb's reduction of Jesus to less than divine and his dismissal of substitutionary atonement as Anselm's misinterpretation of Paul does not seem to hold up when compared with representative scholarship. ${ }^{94}$

Both Wesley and Cobb recognize the movement from one dominion to the other, moving from the law of sin and death to the law of the Spirit. Some representative scholarship treats the law of sin and death and the law of the Spirit as two different perspectives of the Mosaic law. ${ }^{95}$ The first perspective is a law that is unable to be kept and therefore brings condemnation to those under the curse of the law. The second view or use of the law is a positive one, combined with the empowerment of the Spirit to participate in the obedience of faith by keeping the law. ${ }^{96}$ Those who recognize this second position call for both a forensic as well as a participatory nature of the nomos of the Spirit. ${ }^{97}$ The Spirit is the agent that enables believers to keep and fulfill the

Kasemann is only willing to say a certain likelihood should be considered. He sees the pre-existent, sent Son as more Johannine than Pauline. Kasemann, Romans, 216. Dunn cautions against impressing later incarnational theologies onto Paul, but he also does not want to simply extract the theology from Paul. He would rather gently recognize what is in Paul. Dunn, Romans, 420-421.

${ }^{93}$ Fitzmyer, Romans, 484-485.

${ }^{94}$ Cobb, Jesus' Abba, xvii, 23; Cobb and Lull, Romans, 36-38.

${ }^{95}$ Schreiner, Romans, 400; Dunn, Romans, 416.

96 "Since faith and Spirit clearly belong together in Paul's theology, even if for the sake of analysis, he hardly brings them together in Romans (but cf. particularly Gal 3:1-14), the most obvious corollary is that 'the obedience of faith' (1:5) is another way to describe "walking according to the Spirit"' Dunn, Romans, 416-417. See also Schreiner, Romans, 400.

${ }^{97}$ Schreiner, Romans, 405. 
requirements of the law and also to participate in obedience. ${ }^{98}$

The second group of scholars, when referring to the interpretation of the nomos of the Spirit, seem to be in agreement with Cobb. The nomos of the Spirit is a new organizing principle of life and this has nothing at all to do with the Mosaic law. ${ }^{99}$ This is the sphere, dominion, rulership, or governance of the Spirit in the life of the believer. The new life ethic that is expressed as walking according to the Spirit, instead of according to the flesh, is governed by the Spirit. ${ }^{100}$

In some cases, the governing is an internal motivation and guidance. ${ }^{101}$ It is also expressed with the language of possession. ${ }^{102}$ The believer is taken over by the Spirit. ${ }^{103}$

98 "The notion that verse 4 is forensic, however, should be rejected.... Paul does not envision believers keeping the law in their own strength. But it would be a serious mistake to conclude from this that the actual obedience of believers is excluded. The obedience of believers has its basis in the work of Christ on the cross, and this provides the platform on which believers receive ability to keep the law. The keeping of the law is God's work, yet this does not exclude human activity and obedience. The two are not mutually exclusive." Schreiner, Romans, 405. Internal empowerment of the believer could possibly suggest an ontological entering of the Holy Spirit within the believer. However, with representative scholarship's rejection of the ontological union with Christ it is more probable that the emphasis is on the moral surrender to the governing of the Spirit. This is an ethical action of the believer to live according the Spirit's leadership which is empowered by the Spirit. Does empowerment require a union of divine-human reality/being? Wesley thought so, but this would seem to be a strange conclusion if the union with Christ is not ontological according to representative scholarship.

99 "Thus qualified, nomos no longer refers to the Mosaic law. Paul indulges in oxymoron as he now applies nomos to the Spirit, which in his understanding is anything but 'law.' Rather, the law of the Spirit is nothing other than the 'Spirit of God' $(8: 9 a, 14)$ or the 'Spirit of Christ' $(8: 9 b)$ in its ruling function in the sphere of Christ. It is the dynamic 'principle' of the new life, creating vitality and separating humans from sin and death, indeed, supplying the very vitality that the Mosaic law could not give." Fitzmyer, Romans, 482-483. See also: Moo, Romans, 475.

${ }^{100}$ Fitzmyer, Romans, 482-483.

101 "What Paul assumes is not that the process of salvation is complete but that it has begun, not that their total being has been completely transferred to another realm but that a decisive transfer of allegiance and lordship has already taken place, not that moral effort has been rendered unnecessary but that the inner compulsion of God's Spirit has become the most important factor at the level of primary motivation and enabling." Dunn, Romans, 443-444, 459-460.

${ }^{102}$ Dunn seems to speak of the possession of the Spirit more in terms of the believer possessing the Spirit as a source of empowerment which allows the believer to participate in the obedience of the second use of the Mosaic law. Dunn, Romans, 429-430.

${ }^{103}$ Schreiner points to the passive verbal formations of Paul to suggest that the spirit is the primary 
This kind of dominion of the Spirit is only in its beginning taking into account the eschatological tension. Christians are not fully under the Lordship of Christ and governance of the Spirit until the new age is more fully realized, following the bodily resurrection of believers. ${ }^{104}$

Cobb seems to walk a strange line in between these two interpretations of the nomos of the Spirit. He does teach that the nomos of the Spirit is a new organizing principle for the believer to live by. He also rejects the possession language because of his strong non-coercive stance concerning the luring will of God. For Cobb, however, the participation side of keeping the law and participating in the faithfulness of Christ is what it means to walk according to the Spirit, which seems to be more in agreement with a positive view of the law. Perhaps Cobb might be more in line with those who see the possession of the Spirit as the believer possessing the Spirit rather than the Spirit possessing the believer. By accepting the primordial will of God for their lives and becoming the incarnate Christ, they are therefore a part of the consequential will of God, which for Cobb is the closest he will come to an interpretation of what the Spirit might be.

Both groups of scholars, in their differing interpretations of the nomos of the

agent of action. "All those who have the Spirit manifest that fact by their submission to the Spirit, and conversely those who do not possess the Spirit are not led by the Spirit. The 'leading'... of the Spirit does not refer to guidance for everyday decisions in determining the will of God. It refers to being 'controlled by' or 'determined by' or 'governed by' the Spirit (Murray 1959: 295; Lloyd-Jones 1975: 175; Byrne 1979: 98; Moo 1991: 533; Fee 1994: 563). The passive form of the verb is significant, in that it suggests that the Spirit is the primary agent in Christian obedience, that it is his work in believers that accounts for their obedience (Cranfield 1975: 295; Kasemann 1980: 226)." Schreiner, Romans, 422-423. Once again the question of ontological indwelling or union with the possession of the Spirit is raised. Does the Spirit as the active agent of obedience mean that there must be an interpenetration of being to act upon the soul or mind of the believer?

${ }^{104}$ Dunn, Romans, 443-444, 459-460. 
Spirit, agree that there is a transition to a new age for believers who can now live according to the Spirit, instead of the flesh. There is some suggestion that this transition is an ontological one. If the believer was ontologically of the flesh and is now ontologically of the Spirit, has the believer changed natures? ${ }^{105}$ Living according to the Spirit is also the new mindset that comes with the Spirit. There is a new set of desires and motivations which are instrumentally motivated by the Spirit in the mind of the believer. The mind that was set on the desire of the flesh is now a new mindset focusing on the Spirit. ${ }^{106}$

The interpretation of the indwelling of the Holy Spirit is in line with living according to the Spirit. This is a settled dominion, governance, or motivation of the Spirit upon the mind and actions of the believer. ${ }^{107}$ Wesley's concern for the guidance and governance of the believers' thought, words, and actions finds strong agreement in representative scholarship. Cobb's definition of the participation in the faithfulness of Jesus also resonates with the holistic emphasis of the believer's life. The indwelling of the Spirit in representative scholarship's interpretation of Romans 8 also has some challenges for Cobb. In no uncertain terms, representative scholarship reserves the indwelling of the Spirit for Christians. The indwelling is spoken of as the very definition

105 “'This is manifestly the language of ontology' (Moo 1991: 518-19; Fitzmyer 1993c: 488; Fee 1994: 539-40). Cranfield (1975: 385) mistakenly blunts the ontological character of the text by saying that those who "are" of the flesh are equated with those who "walk" according to the flesh, and thereby puts the emphasis on behavior, rather than being. In doing this he actually reverses the argument of the text. What Paul communicates in verses 5-11 is that those who 'walk' by the flesh or the Spirit do so because they 'are' of the flesh or the Spirit. In other words, his argument is that behavior stems from the being or nature of a person. Incidentally, this is powerful evidence that 'flesh' and 'Spirit' involve the 'nature' of human beings. These terms should certainly be interpreted in redemptive-historical categories, but redemptive history should not be pitted against ontology." Schreiner, Romans, 410-412.

\footnotetext{
106 Schreiner, Romans, 410-412; Dunn, Romans, 426-428, 441-442; Fitzmyer, Romans, 488-489.

${ }^{107}$ Dunn, Romans, 429.
} 
of what it means to be a Christian. ${ }^{108}$ Cobb would not have a disagreement with this on the surface. The incarnated Logos, as the Christ realized in the lives of those who choose to follow the lure of Christ, works within his theology. If, however, the indwelling of the Holy Spirit is the empowering presence of the Father, as the Spirit of God, or of Jesus as the spirit of Christ, and is reserved for those who are Christians, this would seem to limit the validity of the consequential nature of God within the dipolar panentheistic system. ${ }^{109}$ These statements are reminiscent of the statements of classical theology, agreed with by Wesley, that the presence of God within, is reserved for the just. ${ }^{110}$

The indwelling of the Spirit, as the definition of what it means to be a Christian, is made stronger by representative scholarship's agreement that the indwelling of the spirit is synonymous with being "in Christ". ${ }^{111}$ There is a careful distinction between Christ and the Spirit; these are not synonymous. This is clearly in disagreement with Cobb. In representative scholarship Christ and the Spirit are distinguishable for Paul, although not separable. ${ }^{112}$ Paul may not have had the clear distinction of the persons of the Trinity

108 "Christian is indwelt by the Spirit of God. Indeed, this is just what Paul affirms in the last part of the verse, where he denies that the person who does not have the 'Spirit of Christ' can make any claim to being a Christian at all. In other words, for Paul, possession of the Spirit goes hand-in-hand with being a Christian." Moo, Romans, 489-490. Dunn says, "the possession of the Spirit is what constitutes the Christian.... In what amounts to the nearest thing to a definition of 'Christian' in his writings, Paul defines a Christian, albeit in negative formulation, as one who has the Spirit of Christ." Dunn, Romans, 444. See also: Schreiner, Romans, 410-412.

${ }^{109}$ Cobb would probably argue that the empowering presence of the Father is something beyond the general panentheistic presence of God in the world because of the degree to which the person has accepted the primordial will of God in their life. It is still worth quoting Fitzmyer who ties the manifestation of the Father's presence to the Spirit since Christ's resurrection. "The power vivifying the Christian is thus traced to its ultimate source, for the Spirit is the manifestation of the Father's presence and life-giving power in the world since the resurrection of Christ and through it." Fitzmyer, Romans, 490-491. for the just.

${ }^{110}$ See the section in Chapter 2 of this dissertation on the indwelling of the Spirit being reserved

${ }^{111}$ Dunn, Romans, 445-446.

112 "What this means is not that Christ and the Spirit are equated or interchangeable, but that Christ 
explicitly stated in Romans, as the church councils later declared. Nevertheless, there are roots in this passage for Trinitarian theology. ${ }^{113}$ Once again there is an agreement with Wesley's Trinitarian theology within representative scholarship, without being dogmatic about it.

In representative scholarship, both life in the Spirit and the indwelling of the Spirit have a strong tie to the corporate body of Christ. ${ }^{114}$ There is recognition of the plural second person pronoun for both the life in the Spirit and the Spirit of Christ dwelling in the believer. ${ }^{115}$ Both Wesley and Cobb pointed to the significance of the newly baptized believer being united to the Christian community. While representative scholarship did not recognize the corporate nature in Romans Chapter 6, they are more than willing to point it out in Romans Chapter 8 .

There is one final issue in representative scholarship to be noted in relation to the analysis of Wesley's and Cobb's interpretation of Romans 8:1-17 concerning the nature of divine-human indwelling. This is the testimony of the Spirit with the human spirit that the believer is the child of God. Representative scholarship agrees with both Wesley and Cobb that this is a differentiation between the Spirit of God and the human spirit. ${ }^{116}$ This

and the Spirit are so closely related in communicating to believers the benefits of salvation that Paul can move from one to the other almost unconsciously. Again, it is clear that the believer who by faith has come to be joined with Christ (see Rom. 6:1-11) has not only Christ but also the Spirit resident within. The indwelling Spirit and the indwelling Christ are distinguishable but inseparable." Moo, Romans, 491. Dunn suggests that for Christian spirituality Christ and the Spirit are experienced as one. Dunn, Romans, 430. See also: Schreiner, Romans, 413.

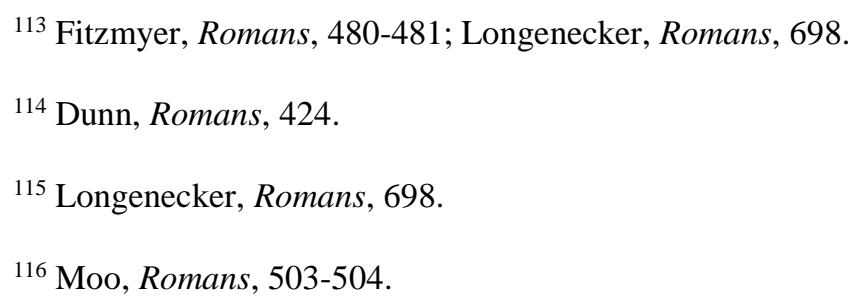


differentiation is a careful protective guard against any idea of the absorption of human spirit within the divine Spirit. They also agree that this is an emotional reassurance for the believer. ${ }^{117}$ Furthermore, they agree that this is a general experience for all Christians, as the indwelling of the Spirit is necessary for someone to be a Christian. Representative scholarship, with Wesley, would agree that this emotional assurance of the testimony is not a case of unique enthusiasm for select believers, but rather a general gift to all believers. ${ }^{118}$

The adoption to sonship, which this testimony confirms, is recognized by representative scholars as being similar to the sonship of Christ, but it is not the same. ${ }^{119}$ The believers are heirs to the close, relational intimacy of Christ and the Father as well as the promised resurrection that is to come. ${ }^{120}$ But there is a unique relationship between the Father and the pre-existent Son who was sent as a sin offering and the believer who is legally adopted into the household of God. ${ }^{121}$ This of course is a challenge for Cobb's interpretation of the indwelling of the Spirit as being the same for the believer and for Jesus, thus making the sonship the same as well.

The analysis Wesley and Cobb, using representative scholarship concerning the interpretation of Romans Chapter 8:1-17, has several implications for the ontological

${ }^{117}$ Dunn, Romans, 454; Longenecker, Romans, 693-694.

118 "Christians are recognized as such when they have the Spirit. This can be said in this unequivocal way only if the Spirit means standing under the present Lord. The claim of enthusiasts to a special position is herewith refuted.” Kasemann, Romans, 223.

${ }^{119}$ Moo, Romans, 499, 503.

${ }^{120}$ Longenecker, Romans, 692-694.

121 The Greco-Roman legal nature of adoption in Romans 8 is applied to the inclusion of the Gentiles in Israel's status as God's people. Moo, Romans, 501. Fitzmyer mentions the legal adoption and the believer being accepted under the "paternal authority" of God. Fitzmyer, Romans, 500. 
nature of divine-human indwelling. First, based on exegetical evidence, there is not much room in representative biblical scholarship for a panentheistic view of the presence of God through the mutual participation in being, which Cobb advocates. The language of participation in representative scholarship is limited to the faithful obedience to the law and this is only for a select group of scholars. The limitation of the indwelling of the Spirit to those who are in Christ also does not allow for a panentheistic presence through the mingling/inclusion of being for all of creation within God's consequent nature.

There are also challenges for Wesley's classical interpretation of the ontological indwelling of the Holy Spirit within the soul. There is no mention of the soul made by representative biblical scholarship or by Paul in this passage. The only possible comparison is the denial that the flesh and spirit refer to an essential-ontological dualism, which Wesley would agree with. The focus for the indwelling of the Spirit in representative scholarship is focused on the realm and rulership of the Holy Spirit for the life of the believer. There is strong possession language and motivational drive by the Spirit, but no talk about an act upon the soul of the penetration of divine being/reality within the being/reality of the human soul.

There are also further research questions that are raised considering the corporate nature of indwelling, with the use of the plural of the second person pronoun and the comparison of indwelling sin with the indwelling Spirit. Is the corporate indwelling of the Spirit perhaps a reference to the divine presence dwelling with or among the people of Israel in the OT age and perhaps God being among his people in the realized eschaton in the New Jerusalem? Does the comparison of indwelling sin with the indwelling of the Spirit strengthen the position of the two ages, with the rulership of sin and death versus 
the Spirit, to the exclusion of an ontological indwelling? Perhaps, as some scholars hint at, the ontological nature of divine-human indwelling could have the effect of an ontological transformation of humanity even though they reject an intermingling/interpenetration of being through ontological indwelling. This transformation is demonstrated through the submission to the lordship of the Trinity and a possible ontological transformation of the character from a mindset focused on sin and death, to a mindset focused on the Spirit and life.

With the conclusion of this section on the interpretation of Romans 8:1-17 regarding the indwelling of the Spirit, it is now time to turn to the final section of this chapter concerning Wesley's and Cobb's interpretation of cosmic groaning for deliverance.

\section{Romans 8:18-22: Cosmic Deliverance}

\section{Introduction}

This final comparison point from Romans Chapters 6-8 is an essential one because it directly interacts with the panentheistic concerns of Cobb, when compared to the way that Wesley views the cosmos. Romans 8:18-22 speaks to the cosmic longing of all of creation for deliverance. ${ }^{122}$ Wesley uses this passage as a platform to speak of the

\footnotetext{
${ }^{122}$ In a more traditional theology the cosmic longing simply means that all of the created world is under the influence of the fall of humanity in to sin. Therefore, every part of creation metaphorically longs for the deliverance from the reign of sin and death that will come at the second coming of Christ. In process theology, however, the longing is demonstrated by different degrees of conscious awareness of every particle of the cosmos. Charles Hartshorne taught pansychism, meaning that everything that exists has a mind, even at the sub-atomic level. All of the cosmos is connected through the relational communities of these minds with one another. Charles Hartshorne, "Panpsychism," in A History of Philosophical Systems, ed. Vergilius Ferm(New York: The Philosophical Library, 1950), 442. Also see Peckham, "Concept of Divine Love", 153; David Skrbina, Panpsychism in the West (Cambridge: The MIT Press, 2005). Cobb expresses the different degrees of consciousness for each occasion of experience. As described in Chapter 3 of this dissertation, an occasion of experience at a high enough degree of awareness becomes a dominant occasion. The degree of awareness of the dominant occasion is high enough that it becomes an occasion of a different kind. All of these various occasions or minds at some level would be longing for deliverance as
} 
difference between humanity and the rest of creation, primarily related to divine presence. Cobb, on the other hand, emphasizes the inclusion of all of creation within the panentheistic system. As with the other two sections of this chapter, Wesley's and Cobb's interpretations will be described, compared, and finally analyzed by a brief survey of representative exegetical scholarship.

\section{Wesley: On The General Deliverance}

Wesley directly addresses Romans 8:18-22 in his sermon The General Deliverance. In this sermon, he engages the question of theodicy. If God is such a kind and loving God, who cares for and provides for his creatures, desiring their happiness, how then can the current state of evil be accounted for? ${ }^{123}$ Wesley finds the answer to this question within this passage written by Paul. All of creation is waiting and longing to be delivered and Wesley suggests that even the "upright heathen" have this longing for deliverance, at least to a certain degree. ${ }^{124}$ The particular relevance of this sermon to the study of this dissertation is the differentiation which Wesley makes between humanity and what he calls "brute creation." 125

Wesley believes there are many similarities between humanity and the rest of brute creation. According to kind, all of brute creation has been given a "principle of selfmotion." All of creation is cared for by God. Brute creatures have a "degree of understanding." They have been given will and the power of choice and each was created

they are lured forward by the primordial will of God towards his consequential will.

\footnotetext{
${ }^{123}$ Wesley, The General Deliverance, 241.

${ }^{124}$ Wesley, Explanatory Notes of NT, 395.

${ }^{125}$ Wesley, The General Deliverance, 243.
} 
"perfect in its kind." They have a balance between their passions that is guided by their understanding. ${ }^{126}$ These things both humanity and the rest of brute creation share, even though humanity was created with dominion over brute creation.

What is the "barrier" or differentiation between humanity and brute creation, according to Wesley? It is not reason as others have suggested, but rather the ability of "knowing, loving, and obeying God." ${ }^{127}$ Humanity is the mediatory link between God and the rest of creation. Human moral agents are able to relate directly to God in accordance to God's dominion over them. The rest of brute creation, however, is under the dominion of humanity and they act in obedience to humanity. When humanity chose not to continue in relationship with God by sinning, the communication and blessings of God upon the rest of creation were cut off. Humanity was the channel through which these blessings flowed to the rest of creation. ${ }^{128}$ As humanity loses its perfection so does the rest of creation. ${ }^{129}$

Wesley makes his point with greater clarity by describing the humans who choose not to know and love God as themselves being reduced to brute creation. They reject the very nature of what it means to be human and are thus reduced to brutes themselves.

\footnotetext{
${ }^{126}$ Wesley, The General Deliverance, 243-244.

${ }^{127}$ Wesley, The General Deliverance, 244.

128 "As all the blessings of God in paradise flowed through man to the inferior creatures; as man was the great channel of communication, between the Creator and the whole brute creation; so when man made himself incapable of transmitting those blessings, that communication was necessarily cut off. The intercourse between God and the inferior creatures being stopped, those blessings could no longer flow in upon them. And then it was that 'the creature,' every creature, 'was subjected to vanity,' to sorrow, to pain of every kind, to all manner of evils: Not, indeed, 'willingly,' not by its own choice, not by any act or deed of its own; 'but by reason of Him that subjected it,' by the wise permission of God, determining to draw eternal good out of this temporary evil." Wesley, The General Deliverance, 245.
}

${ }^{129}$ Wesley, The General Deliverance, 246. 
Wesley says that knowing and loving God is the only mark which separates humanity from the rest of creation. ${ }^{130}$ Humanity's restoration then is for each individual to turn their attention back to knowing, loving, enjoying, and obeying God. This is why all of creation awaits the revealing of the sons of God, for when it is complete then all of creation can be restored to the measure of which the image of God has been stamped upon it. ${ }^{131}$

What does all of this have to do with the ontological nature of divine-human indwelling? The terminology of "knowing and loving" God, which is used by Wesley here is directly connected to the language of Thomas Aquinas when describing the level of union between the divine and human, reserved for the just. Aquinas teaches three levels of union. The first is the level of general providence for all of creation, the second is for the just who know and love God, and the third is the hypostatic union reserved for the God-man union of Jesus Christ. ${ }^{132}$ Wesley is using classical theological language for the union of the just with God to represent the distinguishing characteristic between humanity and the rest of creation. When this is combined with Wesley's teaching that the indwelling of the Holy Spirit is the basis of the image of God, with which humanity was originally created and is being restored to, the connection between "loving and knowing" God and divine-human indwelling is made all the stronger. ${ }^{133}$ Wesley's statements regarding the condition of a lost human being equal to the rest of brute creation, because

${ }^{130}$ Wesley, The General Deliverance, 252.

${ }^{131}$ Wesley, The General Deliverance, 250.

${ }^{132}$ Froget, Indwelling - Thomas Aquinas, 48-49, 54, 63-64. See Chapter 1 of this dissertation for a fuller discussion on this subject.

${ }^{133}$ See Chapter 2 of this dissertation in the section regarding the image of God. 
of the refusal to know and love God, can also, therefore, be connected to the loss of the indwelling of the Holy Spirit.

This classical language in Wesley, and his differentiation between justified humanity and the rest of creation, will most likely bring a significant point of contrast to Cobb's panentheistic view. But before this comparison is made it is necessary to describe Cobb's interpretation of this passage from Romans.

\section{Cobb: Universal Participation in the Glory of God's Presence}

Cobb begins the discussion of the rest of creation longing for deliverance in relation to the participation in Christ's suffering, which will lead to the participation in Christ's glory. Cobb then defines the glory that can be participated in as divine presence. ${ }^{134}$ Cobb recognizes that Paul is initially speaking of faithful believers that will participate in the glory. He then expands the participation to the rest of nature or the created world. For Cobb, Paul is teaching that all of the created order has an opportunity to participate in the glory of God, because Paul has stated that all of creation is longing for deliverance from suffering. ${ }^{135}$

Cobb then uses reason to expand participation in glory from the believers and the natural created world to include the non-believers as they are also a part of the created world. This brings about the possibility of a universal participation and therefore salvation in glory which is God's divine presence. ${ }^{136}$ This is consistent with Cobb's

${ }^{134}$ Cobb and Lull, Romans, 121.

135 "Although the revelation of the radiant splendor of God's presence was to be in and through the participation of the faithful in the splendor of the risen Christ, Paul immediately turned from this brief statement to how the whole creation would participate." Cobb and Lull, Romans, 122.

136 "We have noted that Paul says nothing directly about the destiny of those who are still in bondage to sin. Yet, if our hypothesis about his understanding of creation is correct, they must be included 
panentheism. If all of the cosmos is held within the being of God then of course all of nature does participate in the divine presence and can participate to a greater degree depending on the level of acceptance of God's primordial will.

The greatest struggle that Cobb seems to have with Paul's theology in this passage is the idea of this culmination happening at some sort of apocalyptic end of history. ${ }^{137}$ Cobb's view of reality does not allow for anything to actually come to an end. All of reality is built out of occasions of experience and all of those occasions are held within God, therefore if God goes on then all of those occasions must go on as well. This leads to a very complicated discussion from Cobb regarding the possibility for continued personal existence following death. He seems to lean towards the continuation of an individual's life as consisting of simply being the continuation of important occasions of that individual's life within God. Following Whitehead's suggestions, the creaturely life is taken up into the divine life. Everything that happens in the physical life affects God and is included in his memory. This means that both humanity and the rest of creation are carried on within God. ${ }^{138}$

in the whole, indivisible creation. We have proposed that creation is all that God has brought into being except for the effects of the work of Jesus Christ and the Spirit. It includes even the bodies of those in whom the Spirit dwells. If so, it must certainly include the bodies-and the minds-of others. They were part of the creation that waited in eager longing for the unveiling of the splendor of the children of God. Through this event, they would participate with all the rest of creation in liberation and transformation. In the language of later theology, Paul's vision of salvation was all-inclusive.... One may understand the whole of his mission and the whole of his teaching in the light of this hope and expectation of the radiant splendor of God's presence was to be in and through the participation of the faithful in the splendor of the risen Christ, Paul immediately turned from this brief statement to how the whole creation would participate." Cobb and Lull, Romans, 123.

$$
{ }^{137} \text { Cobb and Lull, Romans, 125-126. }
$$

138 "Our own mentor, Alfred North Whitehead, did not exclude the possibility of additional adventures beyond death. But for him this did not solve the eschatological problem. He felt that, if every event simply occurred and then forever ceased to be, human beings could not find a basis for the meaningfulness of action that is so important to them. This would be as true in a heavenly or glorified state as here and now. His solution was to propose that all that occurs in the creaturely world is taken up into the divine life. What is ephemeral here is everlasting in God. All that people do and feel affects God, and 
Cobb also struggles with and ultimately rejects an apocalyptic view of the end of human history because it tends towards the view of classical theology that the end can be known and sure. Instead Cobb insists that whatever future possibilities there may be must be described as hope. He believes that both Paul and Whitehead support this. Paul, after all, states that faith is regarding the things that are unseen and hoped for. ${ }^{139}$ Because of a complete rejection of any coercive power within the character of God, Cobb cannot accept a realized eschaton with certainty. The eschaton can only be realized if the current conscious state of creation is fully participating in God's glory, or divine presence. This is the consequential will of God, hope, peace, the Kingdom of God, and/or possibly the Holy Spirit according to Cobb's theology. ${ }^{140}$

Cobb's interpretation of the ontological nature of divine-human indwelling consistently extends to include all of creation panentheistically. All of creation is included in the divine participation in suffering and therefore in God's glorious divine presence. It is not reserved only for the just but extended to the unjust as well, because logically they are a part of the rest of creation. Cobb fully acknowledges that Paul does not actually mention the unjust in this passage, but his panentheistic mindset demands that they are included as well. ${ }^{141}$

for this reason human actions have the importance that is necessary to give life meaning. Everything that happens matters not only to creatures but also to God, and recognizing this fact calls us to bring about what good we can. There is also a kind of resurrection. What perishes in the world lives on in a transformed state, sharing in the splendor of God. This proposal agrees with Paul that the whole cosmos is, in this way, 'saved.' God's inclusion of creaturely events is not limited to human ones. Sparrows are included as well." (emphasis added) Cobb and Lull, Romans, 126.

\footnotetext{
${ }^{139}$ Cobb and Lull, Romans, 127.

${ }^{140}$ See Chapter 3 of this dissertation.

${ }^{141}$ Cobb and Lull, Romans, 123.
} 


\section{Wesley and Cobb Compared}

Both Wesley and Cobb are concerned for the fate of the whole created order. They both recognize in this passage of Romans that Paul portrays all of creation as participating in the deliverance of the sons of God in some way. The similarities seem to end here, however, at the most general stage of comparison. Wesley uses this passage in Romans to differentiate between humanity and the rest of creation, while Cobb uses it to bring them both together within universal participation. Cobb uses passages from Wesley concerning the World-soul to suggest that if Wesley had the scientific knowledge that we have now, Wesley might have accepted a panentheistic worldview. ${ }^{142}$ This is possible since Wesley was influenced by classical and current thought of his time; but it would seem to go against Wesley's direct theology referenced in his use of Romans 8 .

For Wesley, the specific difference between humanity and the rest of creation is the ability of humanity to know and love God. Humanity is the mediatory instrument between God and the rest of creation. Cobb is suggesting that all of creation is included in a similar kind of participation that humanity has the potential for within the glory of God, that is, His divine presence. For Cobb, everything affects God because everything is within God, and thus this means that every part of creation can know and love God.

Cobb also extends universal participation in God's presence to those who are unjust, even though he acknowledges that Paul does not mention the unjust in this passage. This is a direct contradiction to Wesley's emphasis on the restoration of the image of God, which is the indwelling of the Holy Spirit only being available to the just. Wesley also clearly states that the Holy Spirit, God's presence, was removed at the fall

\footnotetext{
${ }^{142}$ Cobb, Grace and Responsibility, 51-52.
} 
and can be lost again by any believers who continue to shun the working of the Spirit in their lives. $^{143}$

In addition to the concerns of divine presence, Wesley clearly teaches a continued conscious afterlife. For Wesley, this begins with the soul directly after death and is then reunited with the body at the time of the resurrection. ${ }^{144}$ Cobb emphasizes the need for the body at the resurrection as a whole rather than any sort of dualistic deportation of the soul or spirit if there is to be any after life, which he is not certain of. ${ }^{145}$ Given this comparison and differentiation between Wesley and Cobb on this passage concerning the participation of creation in salvation, it would be helpful to find some suggestions for clarity from representative biblical scholarship.

\section{Evaluation of Wesley and Cobb}

Cobb and Wesley both have their interpretations of Scripture which reflect their systems of understanding concerning divine-human indwelling. Cobb includes all of the cosmos panentheistically and Wesley pointed out the differentiation between the human and sub-human creation. Representative biblical scholarship seems to largely be in agreement with Wesley's interpretation regarding the issues in this passage, including the interpretation of what creation includes, the reservation of the glory for believers only, and a certain future event and resurrection to an afterlife.

The majority of representative scholarship is in agreement that Paul's use of "creation" in this passage is referring to the collective sub-human creation personified

\footnotetext{
${ }^{143}$ Wesley, Great Privilege, 233.

${ }^{144}$ See Chapter 2 of this dissertation.

${ }^{145}$ Cobb and Lull, Romans, 128.
} 
with groans for deliverance. ${ }^{146}$ The interpretations of church history have been laid out, some of which include humans (both believers and non-believers) and even angels in the interpretation of creation. ${ }^{147}$ Representative scholarship has argued this inclusiveness away, however, in favor of creation, in this passage, including only that which is nonhuman. This is emphasized by the subjection to the age of sin and death not being accomplished by the will of the "creation." Humanity willingly chose sin and death through Adam, while the rest of sub-human creation did not. ${ }^{148}$ Scholarship also makes the distinction between the believer and the non-believer being included in the future glory in Romans 8:23, because this particular groaning is a corporate groaning of nonhuman creation, along with believers who have received the first fruits of the Spirit. The Spirit is the one producing eschatological longing in believers and, therefore, nonbelievers who do not have the Spirit do not have the longing. ${ }^{149}$ The anticipated eschaton is restricted to a Christian destiny. ${ }^{150}$

The general consensus of the non-human inclusion within the understanding of creation creates problems for Cobb's interpretation in which he tries to logically argue that the non-believer is included within the created order. Representative biblical

${ }^{146}$ Longenecker, Romans, 721-723; Schreiner, Romans, 435, 438; Kasemann, Romans, 232-233; Moo, Romans, 514; Dunn, Romans, 472, 487; Fitzmyer, Romans, 506-507.

${ }^{147}$ Longenecker lays out the different interpretations and then presents points as to why representative scholarship deems the human-inclusive interpretations invalid. Longenecker, Romans, 721723.

${ }^{148}$ Kasemann, Romans, 234; Dunn, Romans, 469-470.

${ }^{149}$ Dunn, Romans, 490.

${ }^{150}$ Fitzmyer, Romans, 510. 
scholarship does not allow for a panentheistic inclusion of non-believers in the eschaton nor the anticipation of the eschaton.

Cobb also runs into other problems with representative scholarship in his interpretation of glory as divine presence. Representative scholarship seems to tie glory with freedom rather than with divine presence. ${ }^{151}$ The glory that is being anticipated and makes Christian suffering worthwhile, is the realized liberation from the age of sin and death to a fully realized eschaton. ${ }^{152}$ Even if freedom and glory could be distinguished from one another, they are future realities. ${ }^{153}$ This means that even if glory was divine presence it would not allow for a current panentheistic understanding of reality.

Representative scholarship also recognizes Paul's push towards a coming historical Parousia event. ${ }^{154}$ Cobb is also willing to acknowledge that Paul thought the eschaton would be a soon coming event and he is willing to suggest that Paul may need to be reinterpreted in this situation. ${ }^{155}$ This may be true in the sense that the eschaton did not come as soon as Paul wished it too, but this does not decrease the certainty of it on which Paul bases his hope and teaching. ${ }^{156}$

Representative biblical scholarship demonstrates Paul's emphasis on the bodily resurrection and suggests that the glory that is coming is tied to this bodily renewal as a

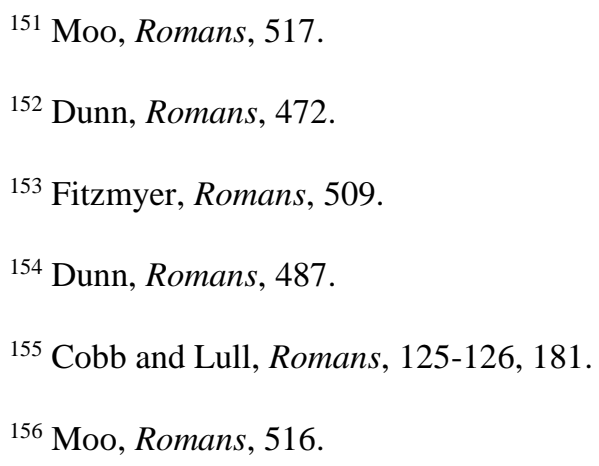


part of the renewal of the whole self. ${ }^{157}$ This is the only possible challenge from scholarship for Wesley's interpretation of this section of Romans Chapter 8. Wesley also taught the importance of the body being reunited with the soul at resurrection, but he did still hold to an anthropological dualism. ${ }^{158}$ This is only a challenge for Cobb's interpretation because of the certainty with which Paul wrote of the resurrection. Cobb has no problem with the body being included in the restoration and as a significant recognition of the self. ${ }^{159}$

This final passage of comparison concerning the ontological nature of divinehuman indwelling, does not offer many challenges to Wesley. It does however offer significant challenges for Cobb. It may be true, as Cobb would probably claim, that these representative scholars are simply a part of the substantialist camp as they view reality. This has only been a brief survey of some of the major representative exegetical scholars in the book of Romans. A fuller study of more theological and speculative scholarship may yield more support for Cobb. Cobb does, however, build on historical critical exegetical work and therefore is open to exegetical evaluation from these representative scholars. What is also clear is that Cobb's acceptance of Whiteheadian views have clearly influenced his interpretation of this passage. The panentheistic interpretation seems to be well beyond a historical reflection of Paul's understanding. Wesley's writing on this passage does not directly mention divine-human indwelling, but it is in clear contrast to

\footnotetext{
${ }^{157}$ Fitzmyer, Romans, 510. Also reference the discussion earlier in this chapter regarding soma being recognized by scholarship as the whole-self. humanity.

${ }^{158}$ See Chapter 2 of this dissertation regarding Wesley's interpretation of the ontology of

${ }^{159}$ See Chapter 3 of this dissertation regarding Cobb's interpretation of the ontology of humanity.
} 
Cobb's panentheistic view. Wesley's clear and specific differentiation between humanity and the rest of the natural world, in the ability to know and love God, places a significant point of contention between his classical theism and Cobb's panentheism.

\section{Summary and Conclusion}

In this chapter, Wesley's and Cobb's interpretations of the ontological nature of divine-human indwelling are given a scriptural point of reference for direct comparison. Romans is a significant book for both theologians and therefore is a good point of comparison between the two. The similarities and differences between Wesley and Cobb, as they interpret Romans 6-8, also gives a good point of reference to compare their understandings with representative scholarship and discover the way that their respective theologies affect the way they interpret Scripture.

In the first section of this chapter, regarding baptism in Romans Chapter 6, both Wesley and Cobb tied baptism to union with Christ. Wesley states that baptism is the external sign of the internal act of the Holy Spirit upon the soul for the engrafting associated with new birth. This demonstrates Wesley's emphasis on the classical theological body/soul dualism and resulting ontological union of the divine being/reality penetrating being/reality of the human soul. Cobb presents baptism as a non-substantial participation of the believers with the historical events of the Christ event. His panentheistic redefinition of reality demands a general ontological indwelling through mutual indwelling and inclusion of the human being/reality within the divine being/reality. Representative scholarship offers challenges to both of these interpretations, pointing away from an ontological union. The emphasis is instead on the beginning of a new epoch or age. The old age under the sphere of sin and death, with 
Adam as humanity's representative, has now moved into the new age in the sphere of the Spirit, with Christ as the representative of humanity. The union is understood as primarily forensic, moral, and representative on the basis of submission to divine rulership in the life of the believer rather than the kinds proposed by Wesley and Cobb. Baptism is a demonstration of a believer dying to the old age of sin and looking forward to the full realization of the new age to come when the righteous will follow Christ in bodily resurrection.

The second section of this chapter discusses life in the spirit and Paul's direct statements regarding the Spirit's indwelling. For Wesley, this is an emphasis on the guidance, direction, and assurance of the Holy Spirit upon the soul of the believer. The Spirit offers holistic guidance to the thoughts, words, and actions of the believer. Cobb teaches, once again, a non-substantialist mutual indwelling. The believer participates in the faithfulness of Jesus by which they become the children of God in the same way that Jesus did. Representative scholarship agrees with both theologians regarding the guidance and direction of the whole of the Christian's life through the work of the Holy Spirit. In fact, a Christian is defined as someone who has the Holy Spirit. This, however, creates problems for Cobb recognizing that the presence of the Spirit is reserved only for the just and once again emphasizes the sacrificial death of the pre-existent son of God. Jesus' Sonship with the divine Father is similar yet different from the rest of redeemed humanity. Wesley also faces challenges considering that representative scholarship does not mention the soul in this discussion of indwelling and points to a more holistic understanding of theological anthropology in Paul's teaching. Holistic anthropology is a point of agreement between Cobb and the representative scholarship. 
There does seem to be some implicit confusion of ideas from representative scholarship. For example; it would seem that the possession of the Spirit, used by some to express the new life in the Spirit, could be some sort of ontological union. The same scholars, however, describe the union with Christ and the indwelling of the Spirit as identical. The persons of Christ and the Spirit are differentiated from each other, but it is through the Spirit that the believer is united to Christ. Since the union with Christ in chapter 6 of Romans is not an ontological joining of divine/human beings/realities it should follow that the indwelling of the Spirit through indwelling would be the same.

Perhaps, the ontological possibilities in this new life in the Spirit are in regards to an ontological transformation of the nature of human persons as the effects of an nonontological indwelling. The first nature, under the rulership of the desires and mindset of the flesh, will be transformed into a new nature under the rulership of the desires and mindset of the Spirit. The comparison of indwelling sin with the indwelling Spirit has more to do with spheres or rulership, guidance, and a new age than an ontological indwelling of a divine being with a human being. Indwelling sin is not an actual being but rather the law of $\sin (\operatorname{Rom} 7: 20-23)$ contrasted to the law of the Spirit. Is it possible that there is a alternative way of interpreting the ontological nature of divine-human indwelling outside of classical soul-indwelling and process panentheistic all-inclusive indwelling by focusing on the ontological transformation caused by a non-ontological indwelling rather than focusing on an interpenetration/intermingling of being? This brief survey, set forth as an analytic tool for the comparison of Wesley and Cobb, is not sufficient to draw a definitive conclusion. It is rather a possible indicator for the need of a full canonical study in order to better understand the ontological nature of divine-human 
indwelling. This is, however, far beyond the scope of this dissertation.

The third section of comparison for this chapter, regarding Romans 8:18-23, dealt with the understanding of the connection between general creation and the indwelling of divine presence. Wesley uses this passage to differentiate between humanity and brute creation. He believes the separating difference is the ability of humanity to know and love God. This is the classical theological language of Thomas Aquinas for the union of the righteous with Christ. A union Wesley believed was lost at the fall and can be either restored or lost forever depending on the choice of the individual human. Cobb, in contrast, suggests that Paul is including non-believers as well as sub-human creation within the term "creation." He, therefore, reasons that all of creation is participating in the longing for deliverance and the glory of God, which is divine presence. Cobb's panentheism demands that all of creation be within divine presence and able, therefore, to know and love God.

Representative scholarship agrees more with Wesley on this discussion. Paul's use of the term "creation" is limited to sub-human creation, to the exclusion of believers, non-believers, and angels. The believers, however, do participate in the longing for deliverance as those who have received the first-fruits of the Spirit. This leaves out the non-believers entirely from the participation with or in the future glory. Glory is tied more with freedom than divine presence and even if it were divine presence it will not be realized until the time of the bodily resurrection at the eschaton, which Paul speaks of with certainty. The ontological nature of divine-indwelling is not explicitly addressed in this passage by representative scholarship, except to demonstrate that Paul was non- 
inclusive of unrighteous persons in this passage and, therefore, Cobb's panentheism is excluded.

In summary of the comparison of Wesley and Cobb with representative scholarship, the presuppositions of their systems are shaping the way in which they believe that Paul taught divine indwelling. Wesley was implicitly leaning on classical dualistic understandings of anthropology, which affected his interpretation of these scriptural passages. Cobb is overtly declaring and imposing Whitehead's philosophy as his interpretive lens for theology and Scripture.

Another point of comparison of Wesley and Cobb with one another has to do with Cobb's suggestions that Wesley would possibly follow along with his interpretation of a panentheistic reality given current scientific understanding. Cobb claims that Wesley's world-soul references suggest that he already supported some of these suggestions. There are many points of agreement between Wesley and Cobb, as demonstrated in this chapter. The comparison, however, does not allow for the close connection that Cobb suggests. The differences on the nature of Jesus and his sacrifice, the non-substantial union of the believer with Christ (the logos), which allows for the union of the believer to be the same as that of Jesus, and the inclusion of all of creation, including the unrighteous, within a relationship with God that Wesley reserves for the righteous, create too large of a gap for Cobb to bridge to a full theological merger with Wesley.

The final chapter of this dissertation, to which this research now turns, will be present a summary and some conclusions based on what has been discovered so far, as well as some suggested implications for further research. There are questions that this research has raised about the ontological nature of divine-human indwelling that point 
beyond the scope of a comparison between Wesley and Cobb. 


\section{CHAPTER 5}

\section{SUMMARY, CONCLUSIONS, AND IMPLICATIONS \\ FOR FURTHER STUDY}

\section{Introduction}

In this final chapter of this dissertation the first section will consist of a summary of each chapter. The second section will present the conclusions of the study regarding the similarities and dissimilarities between Wesley and Cobb as well as some evaluative statements based on the Scriptural analysis in Chapter 4. The final section will present questions and suggestions for further research.

\section{Summary}

\section{Chapter 1: Historical Background}

In Chapter 1, the historical background for the study of the ontological nature of divine-human indwelling is laid out in two sections. The first section spans from the Greek Philosophers, through the church fathers, scholastics, and reformers ending with Wesley. The second section describes the development of Christian understandings of divine-human indwelling from the beginning of the Modernist period through the inception of process theology leading to Cobb.

This historical outline traces the lines of two primary interpretations of the ontological nature of divine-human indwelling, both seeking an explanation that includes the transcendence and the immanence of God. The classical-theological interpretation 
emphasizes transcendence over immanence, explaining the ontological nature of divinehuman indwelling on a dualistic basis. The divine reality/being is beyond the physical world and can therefore only be united to the part of human reality/being that is also beyond the physical. In this system of indwelling, the divine being/reality is substantially united with the being/reality of the human soul as either a formal or efficient cause. The other interpretation of divine-human indwelling emphasizes immanence over transcendence. There are some interpretations that have gone to the complete immanence of pantheism, but for those who maintain a transcendent balance, panentheism is their answer. The di-polar nature of the divine allows for all of the cosmos to be included within the divine being while the spiritual pole of the divine is beyond the physical inclusion.

This chapter went on to outline the problem and purpose of the research. The problem was the conflicting views between the classical theistic and process panentheistic interpretations of divine-human indwelling specifically manifested in the models of Wesley and Cobb. The purpose, therefore, was to use John Wesley and John B. Cobb. Jr. as examples of comparison between these two views and then evaluate both of them through the scriptural lens of Romans Chapters 6-8. The models were to be compared, in subsequent chapters, based on three categories: the ontology of God, the ontology of humanity, and the ontology of divine-human indwelling. The third category was then to be evaluated in chapter 4 on the basis of representative scholarship regarding Romans 6-8.

Through this comparative study and evaluation it can be demonstrated that an alternative model that might cohere better with the biblical depiction of indwelling should 
be pursued. It is beyond the scope of this dissertation, however, to provide that model. What was within the scope of the dissertation was the comparison and evaluation of these two theologians' models.

\section{Chapter 2: John Wesley}

In Chapter 2, John Wesley's understanding of the ontological nature of divinehuman indwelling was explored and analyzed using the three categories of comparison. First, Wesley's ontology of God is his form of classical theology which allows for God to be providentially present within time and space. God is timeless and transcendent beyond physical reality, as in classical theology, and God is also spirit, which allows him to fill all of space. God's omnipresence is tied with his omnipotence. God must be present in order to act, therefore, because he is omnipresent he can act in providential and sustaining ways for all of creation. Wesley carefully differentiated God from his creation, he may be present everywhere, around and with all things, but he is separate from his creation. Wesley's second major emphasis concerning the ontology of God is a Trinity of three coeternal persons. Jesus is both divine and human. The Holy Spirit is differentiated from the ontological reality of God as spirit in general. The Holy Spirit is the primary agent of sanctification who is therefore primarily grieved when a human rejects salvation and the source of personal love that is shared with humanity from the Godhead.

Second, Wesley taught a dualistic ontology of humanity in agreement with classical theology. The body is made up of the basic four elements of the cosmos but they required a soul for animation. The soul and body are united with one another but they can also be separated from one another in the same way that the unrighteous soul can be separated from God. The immortal soul is separated from the body at the moment of 
death and then either united with God in timeless beholding or eternally separated from God in torment. Wesley did teach a bodily resurrection when the soul will be reunited with the body, but this will be a new spiritual body. Another important point for Wesley concerning the ontology of humanity is that humanity was originally created in the image of God. The image of God is expressed as including moral choice, the right to rule over the rest of creation, and a union with God through the indwelling of the Holy Spirit. At the time of the fall, humanity lost the image of God and was reduced to the same nature as the rest of brute creation. Human beings no longer had the presence of the Holy Spirit, moral choice, or the right to rule. For Wesley, the restoration of the image of God is the process of salvation.

Third, Wesley was in agreement with the classical theological position on the ontological nature of divine-human indwelling by expressing the indwelling of the Spirit as both the formal and efficient causes upon the soul and the life of the believer. The stamp of the image of God upon the soul demonstrates the formal cause; and the enabling of the soul to have the knowledge and love of God as well as the transformation of life, thought, and deed demonstrates the efficient cause of the Spirit within the soul.

Wesley taught that God must be present in order to act. If the acts of the Spirit are evident within the soul and the life of the believer then the Spirit's presence must also be there. Wesley demonstrated his classical theology by also reserving the indwelling of the Spirit for the just. It is only those who accept the substitutionary death of Jesus that are able to be restored in the image of God. The original indwelling of the Spirit as the image of God in humanity has been lost and is only available to the person who chooses to believe. This presence of the Spirit may be rejected as well once a person has received it 
if they continually turn away from the influence of the Spirit to transform their lives through the love and knowledge of God. Wesley described the difference of eternal destiny between those souls who return to God and the souls who reject the Holy Spirit to be separated from God forever in hell.

Wesley spoke of the indwelling of the Spirit in many different ways including spiritual respiration, substantial happiness within the soul of the just, and the witness of the divine Spirit to the human spirit. For Wesley, to be a Christian was to be indwelt by the Spirit. The ontological nature of this divine-human indwelling was an ontological union of the divine being/reality penetrating within the being/reality of the human soul through formal and efficient cause reserved for the just. The Holy Spirit was substantially united with the soul both as the form around which the soul was transformed and the agent who was doing the transformation.

\section{Chapter 3: John B. Cobb Jr.}

In Chapter 3, the same process for research and study used for Wesley's system of understanding was applied to Cobb's writings. The first category was the ontology of God. In order to understand Cobb's ontology, it is necessary to understand his cosmology. Cobb follows the philosophy of Alfred N. Whitehead. In this conceptual philosophy, all of reality is redefined as non-substantial. Reality, rather than being made up of physical building blocks of substance, is instead an organization of energy-events or better yet, occasions of experience. All of reality is, therefore, based on a relational understanding of these occasions of experiences consciously or unconsciously interacting with one another. God fits into this reality as the all-inclusive spirit which interacts with each occasion of experience. God is historical in nature and dependent upon the cosmos 
as a part of his being. Cobb attempts to find a middle ground between what he describes as classical theology's “deistic view" of a God removed from the world and pantheism's absorption of the personhood of God into creation. He names this middle ground is panen-theism. All is in God and God is in all, yet God is beyond all. Cobb uses Whitehead's di-polar view of God to express this. The cosmos as the possible divine physical pole (although this is too substantial for Cobb) and the mental pole which is God's creative will luring all of creation towards their best version of God's consequential will.

Cobb reinterprets the Trinity as non-substantial as well and discards the idea of three persons. For Cobb, the Trinity is at the most a trinity of natures or wills. God has a primordial will/nature, which could be called the Logos (the son), and a consequential will/nature, which could be called the Spirit, Kingdom, or Peace of God. The Logos is the creative intention for all of the cosmos. As each individual subject of the cosmos accepts the intention of this initial aim (the logos) for its life it becomes the incarnate logos, which Cobb calls Christ. Cobb is careful to differentiate between Jesus as "the" Christ compared to the rest of creation. Jesus was so responsive to the logos that the incarnation of the Christ was "identified" with his personhood. The rest of creation does not match this degree of incarnation, so much so, that Cobb insists that Jesus was of a different kind of Christ than the rest of the cosmos can be. Cobb, however, does not accept Jesus as divine nor "synonymous" with Christ. ${ }^{1}$

\footnotetext{
${ }^{1}$ In philosophical terminology, there is an apparent contradiction here between Cobb's suggestion that Christ is "identified" with the personhood of Jesus and yet that Jesus is not "synonymous" with Christ. If the incarnation of Christ is identical to the personhood of Jesus it would seem that Jesus would need to be synonymous with Christ. Because Christ is the incarnation of the logos within all of creation, however, Christ cannot be limited to Jesus only and therefore cannot be synonymous with Jesus. Jesus is Christ by degree compared with the rest of creation. But Cobb is careful to argue that the degree is so much greater for Jesus that he is Christ of a different kind from the rest of creation.
} 
The Spirit for Cobb refers to the consequential will of God. Once the primordial will has been accepted or not and a cosmic subject is incarnated as Christ they also are a part of the consequential will of God, which could possibly be called the Spirit, Kingdom, or Peace of God. God also simply is spirit; therefore, Cobb can use the Spirit of God almost interchangeably with God, Christ, or perhaps God's mental pole. Another significant point for Cobb's ontology of God is his insistence that God is neither omniscient nor omnipotent in the classical sense. He knows only what has been and is, but not what will be. God is not all powerful, because all parts of the cosmos have freedom to work for or against his intentional will. According to Cobb, God's love and power is always persuasive and never coercive. Even better than persuasive, God's love is liberating the subjects of the cosmos to the possibilities they can choose from.

Cobb's understanding of the ontology of humanity is also non-substantialist. Each person is a collection of occasions of experience. Once a particular occasion gains the ability to direct or organize the other occasions of a community of occasions it becomes the dominant occasion. The dominant occasion can then begin to act within its own selfinterest and eventually transcend the various aspects of its person including body, mind, logic, and emotion. This transcendent occasion is called the human spirit. The human spirit can observe and take responsibility for its own community of occasions and also recognize that it has no control over the other occasions beyond its influence. For Cobb, this evolution of the person reaches its culmination in spiritual existence. The structure of spiritual existence, for Cobb, is a distinctly Christian existence. The reason for this is because the dominant occasion emerges from being a psyche to a spiritual structure by responding to the Spirit of God for their life and existence. 
Cobb blatantly rejects any form of dualism. The spirit of a person may be radical self-transcendence but it is still inclusive, related to, and organizing the body and the other aspects of the psyche. Not only is the spirit of a person tied to the environment of the body, but the individual person is also tied to the environment of the other people around himself or herself and the ecological community of the natural world. While the axial turn of the individual towards individuality is necessary, the corporate engagement with the global occasions of experience is essential as well. Cobb demonstrates his panentheism in his ontology of humanity as well as his ontology of God.

The final category of the ontological nature of divine-human indwelling for Cobb is of course based in the panentheistic non-substantial view of reality. Humanity mutually indwells the divine and the divine mutually indwells all of the cosmos. God coconstitutes the being of all of the cosmos and, therefore, humanity is included within this panentheistic reality. There is an enmeshment of the divine and human beings/realities. The Spirit of God interacts with the human spirit showing the human spirit the possibilities for existence outside of the physical determinism of habit and preestablished patterns. The individual is then free to choose to participate with the creative lure of God's primordial will. ${ }^{2}$ When an individual chooses to do so, they are incarnated by that will becoming Christ to one degree or another. All of the cosmos has the potential to respond to God's call and thus ultimately are a part of God's consequential or realized will. Cobb points to Pannenberg's and Whitehead's explanations of the kingdom or peace of God fully realized. Humanity has the greatest potential to participate in the will of

\footnotetext{
${ }^{2}$ It is important to remember that Cobb's definition of an individual is a non-substantialist one. For a full development of this understanding of individual see the section on the ontology of humanity in Chapter 3 of this dissertation.
} 
God, the prime example being Jesus who was so identified with the logos (the primordial will) that his very self was identified with Christ making him not just a higher degree of Christ but a different kind of Christ.

Chapter 4: Comparison and Evaluation of Wesley and Cobb In Chapter 4, Wesley's and Cobb's interpretations of the ontological nature of divine-human indwelling were compared through their engagement with the scriptural passage of Romans 6-8. There are three primary points in the passage that were used for comparison: 1. Baptism (Romans 6:3-4); 2. A life spent walking according to the Spirit (Romans 8:1-17); 3 . The inclusion of the rest of creation in the longing for deliverance (Romans 8:18-22).

First, Wesley and Cobb share many points of agreement with regard to baptism referenced in Romans 6:3-4. Both claimed that baptism called for a union with Christ and his community of the church. Wesley, however, held on to the union with Christ being one of faith which was in Jesus as the divine sacrificial offering of God. While Cobb chose to focus on the participation with the Christ event through the previous occasions of experience. Cobb reinterprets the righteous living by faith in the book of Romans to mean the righteous participating in the faithfulness of Jesus thus becoming Christ rather than believing in Jesus as Christ the divine Son of God. Wesley also pointed to baptism as the external action, which represents the internal spiritual action of the Spirit upon the dualistically separate soul of the believer for new birth. This agrees with Wesley's dualistic nature of humanity and classical theology. Cobb, in contrast, points to the nonsubstantial participation of the believer through mutual indwelling between human and divine. 
Representative scholarship poses challenges to both theologians regarding their interpretation of baptism in Romans chapter 6. The emphasis among the scholars is on the representation of Christ as a transfer from the representation of Adam. Baptism into Christ's death and the promise of the resurrection to come, point to the old and new ages. The first age under sin death and the second age of life, which is still coming. The ontological nature of the union of the believer and Christ is down played in representative scholarship if not completely eliminated. In this passage, current scholarship does not support the classical interpenetration of divine and human being/reality nor the panentheistic mingling of divine and human being/reality. Instead the forensic and representative nature of the union takes precedence. Representative scholarship also discourages any emphasis in this passage of baptism as a union with the Christian community (although they do mention it later on in chapter 8), which both Wesley and Cobb do emphasize.

In the second passage of comparison, Romans 8:1-17, Wesley focused on the guidance and direction of the Spirit. This guidance is regarding the believer's thoughts, words, and actions. Wesley acknowledged the new rule of the Spirit replacing the rule of sin and death. He also recognized the indwelling of the Spirit as a general gift to all Christians not a unique enthusiastic gift for some. For Wesley, it is the inward impression of the Spirit upon the soul that cleanses the believer from inward condemnation, while the outward condemnation is removed by faith in the death of Jesus Christ. Cobb also focuses on the change from the sphere of sin and death to that of the Spirit. Cobb speaks of the new nomos of the Spirit as the new organizing principle of God. This is reminiscent of the logos being the primordial will of God and the organizing principle of 
the cosmos, which all can respond to. Cobb also argues that the ontological distinction between Christ and the Spirit is not present in Paul and is only a later development of the Trinitarian controversy in the early church. The witness of the Spirit in agreement with Wesley is a general assurance of the believer's new status as a child of God. Cobb, however suggests that this is the same sonship as that of Jesus, once again, downplaying the divinity of Jesus, while Wesley continued to uphold this unique status of Jesus as divine as well as the significance of the propitiatory nature of Jesus' sacrifice. Wesley spoke of the Spirit as the divine agent or efficient cause acting upon the soul, while Cobb depersonalizes the Spirit as the fulfilled consequential nature of God or simply as God himself, not a triune person.

Representative scholarship, regarding Romans 8:1-17, has some agreement with both Wesley and Cobb. They also point to the transfer from one age to another. The law of sin and death is the old age and the law of the Spirit is the new age. There is some disagreement whether the law of the Spirit is a positive view of the Mosaic law or a new organizing principle of life. Scholarship is in agreement with Wesley regarding the atoning work of Jesus' death in this passage. It was by the sending of the son in the likeness of sinful flesh as a sacrificial offering that condemnation is removed and the new life in the Spirit made possible. While some scholars partially agree with Cobb that Paul was not explicit in a tri-person Trinitarian theology, they do see the roots of a Trinitarian theology in the passage and that the son being sent, at the very least, hints towards the pre-existent nature of Jesus.

Perhaps the most significant point in this evaluation of Wesley and Cobb by scholarship is the movement away from an ontological indwelling. Scholars identify the 
union of the indwelling of the Holy Spirit with the union of a believer being "in Christ." Even though the persons of the Spirit and Christ are differentiated from one another. This means that the nature of the indwelling can be no more ontological (interpenetration/mingling of divine and human beings/realities) than the union of being "in Christ" as discussed in Romans 6.

These representative scholars as a group also affirm the indwelling of the Spirit as something that is reserved for the just, which creates problems for Cobb's panentheism. Wesley also is challenged by these commentators as there is no mention of the soul in this passage, but rather a possible ontological change in the believer from a mindset of the flesh to a mindset on the things of the Spirit.

The final passage compared in this chapter is Romans 8:18-22. Wesley used this passage of Scripture to differentiate humanity from the rest of creation. The particular difference being the ability of humanity to know and love God. The rest of "brute creation" does not have direct access to relate to God in Wesley's theology. When humanity fell, they were reduced to the same level as the rest of brute creation. They lost the stamp of image of God, which is the indwelling of the Holy Spirit and thus their ability to relate directly to God. Wesley's use of the knowing and loving God is directly related to the classical language of Thomas Aquinas as the means by which humanity can move beyond the providential presence of God to the unique union reserved for the just. Cobb, on the other hand, uses this passage to argue for a universal inclusion of not only all of sub-human creation but also wicked humanity. This is necessary for Cobb because of his panentheistic understanding of reality. The glory of God, which Cobb defines as the divine presence includes all of creation, and must do so in a panentheistic worldview. 
Representative scholarship supports Wesley in the interpretation of this passage. Paul's reference to all creation groaning for deliverance is limited to sub-human creation only. This is evidenced by Paul's extension of the groaning to the believers as well because they are the first fruits of the Spirit. Therefore, it can only be subhuman creation which is intended in Paul's use for creation and because the indwelling of the Spirit is reserved for the Christian, it cannot include the wicked. The glory of God referred to in verses 18 and 19 is also tied more with freedom in representative scholarship and limited to completion in the future eschaton.

This creates significant challenges for Cobb's teaching on the eschatological tension. On the one hand, all of creation has the opportunity to respond to the logos' lure upon them so that they may become part of the consequential will of God. On the other hand, the presence of God is already manifest, all of creation is included within the being of God. Thus, Cobb's argument that even the non-believer must be included in Paul's language of creation. Cobb, along with the rest of the process community, is less than certain about whether the eschaton will eventually happen. He does agree with representative scholarship that Paul believed that the eschaton was sure to come, but then dismisses that surety because Paul believed that it would come sooner rather than later. While the eschaton's delay is recognized by representative scholarship, they do not point to a lessening of the surety in the interpretation of Paul's writing in Romans as Cobb does. The whole passage from Romans Chapter 6 through Chapter 8 is in the context of two ages and the transference that has already begun with the death and resurrection of Jesus. The surety of the eschaton is a Pauline teaching regardless of how Cobb may want to lessen it. 


\section{Conclusions}

Similarities Between Wesley and Cobb

There are similarities between Wesley's and Cobb's theological systems. The most obvious is Cobb's claiming of his Wesleyan heritage. He still claims to be a Wesleyan theologian. The insistence upon a non-coercive view of the love of God and the will of God upon all of creation is also in agreement with a Wesleyan-Arminian view that salvation is not based on a predetermined predestination of humanity to the fate of the righteous saved or the wicked damned. Both Wesley and Cobb are influenced by the current scientific thought of their day. Wesley revealed this in the way he described the makeup of the human body from the four elements of earth, water, air, and fire and essays appealing to humanity's reason. Cobb's entire non-substantialist view of reality is based upon new-physics.

Both Wesley and Cobb show the influence of the current wisdom of their day affecting their interpretations of Scripture. Wesley presupposes a dualistic view of reality and humanity upon Paul's teaching of the indwelling of the Holy Spirit even though representative scholarship agrees that Paul's view of humanity was a holistic one. Not once does Paul mention the soul in relation to the indwelling of the Spirit in this passage and yet Wesley wrote from his paradigm of understanding regarding the Spirit acting upon the soul. Cobb, as demonstrated in this dissertation, imposes the non-substantial worldview upon Paul. Cobb believes that this imposition actually brings out a fuller understanding of what Paul originally meant when he spoke of the mutual indwelling of the human and divine.

There are other similarities on the surface of the theological interpretations of Cobb and Wesley. They both affirm the transcendence and the immanence of God; that 
God is omnipresent; that there is an assurance and peace found in the testimony of the Holy Spirit with the human spirit; that the Holy Spirit is different from the human spirit; that there is a new age of the Spirit compared to the old age of the law of sin and death; that Jesus was unique compared to the rest of humanity; that the faithful response of the believer affects both the internal motivations as well as the external actions; and that there is some sort of ontological union between the human and the divine. The agreement on these various points, however, doesn't go much deeper than the surface level.

\section{Differences Between Wesley and Cobb}

Beginning with the ontology of God, both Wesley and Cobb teach that God is transcendent, immanent, and omnipresent. However, Wesley taught a dualistic view of the reality, which meant that God is timeless in nature and distinct from his creation, while Cobb teaches that God is fully temporal and includes creation within himself. Wesley held to a full Trinitarian theology of three divine persons interacting with humanity, while Cobb teaches a trinity of natures, not persons. Wesley taught the divinity of Jesus, while Cobb denies the divinity of Jesus and instead speaks of Jesus as the human who most identified with the primordial will of God. Wesley taught that the Holy Spirit was a personal agent acting upon and thus dwelling within the soul; while Cobb tentatively identifies the Holy Spirit with the consequential will of God, which is simply a transition of response enacted by a subject of the cosmos accepting the primordial will of God.

The ontology of humanity for Wesley is also dualistic. The body and the soul, while they are integrated together and thus there is value to the physical body, are distinct and at death will be separated. The righteous soul will return to God and be caught up in 
the beholding of who God is. In contrast, Cobb's non-substance view of reality involves a union of occasions of experience to make up an individual. The human spirit, which can be considered radical self-transcendence, is dependent upon the experiential occasions that have been organized into the physical body. The one can possibly exist without the other, but most likely this would only be as an occasion which is carried on in the organization of the subsequent occasions, which are all held within God. The continuation of an individualistic adventure after death is less likely in Cobb's view.

The ontological nature of divine-human indwelling is once again dualistic for Wesley. The Spirit of God is acting upon the soul, breathing into the soul, and united to the soul in agreement with classical theology through the knowledge and love of God. The indwelling of the Holy Spirit is the image of God which humanity was created with, but also lost at the fall into sin. The presence of the divine as the indwelling of the Holy Spirit can, therefore, only be restored in the just who are willing to accept the atoning sacrifice of Jesus Christ and believe in him. Divine-human indwelling is the penetration of the divine being/reality within the being/reality of the human soul through the Holy Spirit as the formal and efficient cause of transformation.

In contrast, Cobb teaches a mutual indwelling based upon the non-substantial panentheistic reality of the world. All of creation is included within the being/reality of God, therefore, that divine presence can never be removed from any part of creation. Individual subjects of all creation and especially humanity can be incarnated by accepting the primordial will of God, thus becoming Christ to a greater or lesser degree. Cobb rejects any sort of dualism including moral, human ontology, or God and the rest of the cosmos. All of humanity can participate in the faithfulness of Jesus, both by occasions of 
experience in the actual historical events of Jesus' death and resurrection and by greater and greater identification and incarnation of the logos. Jesus remains unique because his degree of incarnation is so much greater that he is of a different kind. The indwelling that Jesus experienced is the same indwelling that is available to the rest of humanity, and to a certain degree the rest of the cosmos, even though none will reach the same level as Jesus did.

Cobb suggests that if Wesley had the same scientific understanding that we have today he would be in agreement with Cobb regarding the non-substantial worldview. But the system of theology which Wesley teaches would not seem to allow for a complete transition to the way of thinking that Cobb has developed based on Whitehead's process philosophy. Wesley may have taught some concept of a world-soul and that God was present everywhere so that he could therefore act everywhere. But to reject Trinitarian theology, the divinity of Jesus, the personhood of the Holy Spirit, and the necessity of the atoning sacrifice of Christ, seems to be too significant a change for Wesley to make. In addition to this, the argument is a non-starter as it is impossible to know what Wesley would have done. It is also significant to note that panentheism wasn't a new idea in Wesley's time, although it was not presented in the same way as process theology articulates it now. There had been panentheistic thought from the time of Plotinus at the very least. Wesley was influenced by eastern thinkers (who tended more toward an immanent God-world relationship) in his theology but he continued to hold to the western dualism of classical theology.

\section{Evaluation of Wesley and Cobb}

In light of the focused scriptural evaluation of Romans 6-8, Wesley and Cobb 
both make valuable contributions to the historical discussion of the ontological nature of divine-human indwelling. Wesley's insistence on the indwelling of the Spirit being something that is reserved for the just based on belief in the life, death, and resurrection of Jesus Christ is affirmed by representative exegetical scholarship. Both Wesley and Cobb's affirmation of a holistic view of the Christian life including, thoughts, words, and deeds is also in agreement with representative scholarship. They both also affirm a transformation of this holistic life from the sphere of the rule of sin and a death to the sphere of the rule of the Spirit as a result of divine-human indwelling. This transformation is something that is still in process for both of them although Wesley's surety of the coming eschaton is more in agreement with representative exegetical scholarship than Cobb's open-ended possibility of a realized kingdom of God.

Perhaps, one of the valuable contributions both Wesley and Cobb make is to engage the current scientific understanding of their time. I suggest that an engagement of current scientific understanding of the physical world is worth considering regarding this discussion as it obviously has a major effect on the understanding of the ontological nature of divine-human indwelling. The caution to this is the imposition of the current scientific understanding upon Scripture in such a way that requires the change of the apparent original intent of the biblical writer. If one takes a high view of Scripture and the inspirational work of the Holy Spirit, then there may be more within the meaning of the text then a mere human author could have understood given the scientific understanding of the day.

There are also some challenges that representative scholarship offers to Wesley's and Cobb's understanding of the ontological nature of divine-human indwelling. The 
primary challenge being the turn away from defining divine-human indwelling and/or being in Christ as the ontological blending of divine and human reality/being. The union with Christ and the indwelling of the Holy Spirit are seen as synonymous by Wesley, Cobb, and representative scholarship. Representative scholarship is in agreement with Wesley that Paul's understanding of the person of Jesus Christ and the person of the Spirit are differentiated, but the union is the same. The rejection of an ontological nature of indwelling is significant for both Wesley and Cobb. Neither the classical theological position of Wesley through the union of the divine being/reality within the being/reality of the human soul nor the panentheistic ontological mutual indwelling of human being/reality included/mingled within the being/reality of God are viable. Representative scholarship recognizes that the dualistic nature of humanity is not in Paul's writings, nor do they allow for the inclusion of wicked humanity within the creation that is longing for deliverance. Thus, making a differentiation between the just and the wicked that would not allow for Cobb's panentheistic interpretation of Romans 8:18-22.

While there may be implicit possibilities for an ontological nature of indwelling in the representative scholarship, there is explicit rejection of an ontological indwelling when defined as the interpenetration/mingling of the divine and human reality/being. The only explicit suggestion for a possible ontological aspect on divine-human indwelling in representative scholarship seems to be the ontological transformation as the effect or fruit of a non-ontological indwelling of the believer from one who is ruled within the sphere of sin and death by a mindset that is focused on the things of the flesh to one who is ruled within the sphere of the Spirit by a mindset that is focused on and empowered by the Spirit. 


\section{Implications for Further Study}

The limitations of this research suggest several questions or steps that could be taken for further research on the nature of divine-human indwelling. First, a wider study of theological interpretations beyond Wesley and Cobb could be helpful. There have been various studies produced, especially concerning the theology of Thomas Aquinas, which were referenced in the first chapter of this dissertation. There does, however, seem to be less work done on this subject within Protestant studies than within Roman Catholic studies.

Second, there are several points concerning indwelling that this dissertation does not directly address and can only ask questions about according to the scope of research in this study. They are as follows: (1) what are the other ways of defining ontological indwelling, (2) is there ontological indwelling within the Trinity, (3) is there ontological indwelling of divinity and humanity in the incarnation. These specific points provide opportunity for further study and comparison.

Third, this study is limited to a study of Romans 6-8, therefore, a full canonical study of the nature of divine-human indwelling within Scripture is needed. Because representative scholarship has denied the ontological nature of divine-human indwelling,

there are many passages in Scripture that would need to be engaged and better understood when considered in the context of the historical dialogue, which presupposes an ontological nature for indwelling.

The holistic nature of human beings which is presented in Paul's use of soma in Romans 8 creates a significant challenge for the classical indwelling of the Holy Spirit with the soul of the believer. The exclusion of the wicked from those who are walking with/indwelt by the Holy Spirit and the creation that is groaning for deliverance in 
Romans 8 cast doubt on a panentheistic system of divine presence/being in union with the cosmos.

There is also the question of ontological transformation as a possible result of indwelling as an open area of future study. Is there a change of essence, being, or simply a different mindset renewed by the Spirit? Is this simply another way of explaining the effect of a moral union with Christ and the Holy Spirit, or is there something more? I believe that there is ground for the possibility that one could describe divine-human indwelling having an ontological effect in agreement with the research in this dissertation. The holistic transformation of humanity, supported by Wesley, Cobb, and representative scholarship alike is worth considering. In further study, I would therefore, also pursue the rest of the canon of Scripture to better understand the transformation of the human ontology that takes place through the renewal of the mind and the awaited eschatological transformation referenced in Romans 6-8.

This dissertation has contributed a thorough study of the understandings of both Wesley and Cobb regarding the ontological nature of divine-human indwelling. It has has also provided a starting point for further study on this topic in Wesleyan studies, process studies, wider theological studies, and a full canonical study of Scripture. 


\section{BIBLIOGRAPHY}

\section{THE WORKS OF JOHN WESLEY}

Wesley, John. Explanatory Notes Upon the New Testament. Fourth American ed. New York: J. Soule and T. Mason, 1818.

Wesley, John. Awake, Thou that Sleepest. Vol. 5. Third ed. The Works of John Wesley. London: Wesleyan Methodist Bookroom, 1872.

Wesley, John. The Circumcision of the Heart. Vol. 5. Third ed. The Works of John Wesley. London: Wesleyan Methodist Bookroom, 1872.

Wesley, John. The Doctrine of Original Sin According to Scripture, Reason, and Experience: Part II. Vol. 9. Third ed. The Works of John Wesley. London: Wesleyan Methodist Bookroom, 1872.

Wesley, John. A Farther Appeal to Men of Reason and Religion: Part I. Vol. 8. Third ed. The Works of John Wesley. London: Wesleyan Methodist Bookroom, 1872.

Wesley, John. The First Fruits of the Spirit. Vol. 5. Third ed. The Works of John Wesley. London: Wesleyan Methodist Bookroom, 1872.

Wesley, John. The General Delieverance. Vol. 6. Third ed. The Works of John Wesley. London: Wesleyan Methodist Bookroom, 1872.

Wesley, John. God's Approbation of His Works. Vol. 6. Third ed. The Works of John Wesley. London: Wesleyan Methodist Bookroom, 1872.

Wesley, John. The Great Privilege of Those Who are Born of God. Vol. 5. Third ed. The Works of John Wesley. London: Wesleyan Methodist Bookroom, 1872.

Wesley, John. The Heavenly Treasures in Earthly Vessels. Vol. 7. Third ed. The Works of John Wesley. London: Wesleyan Methodist Bookroom, 1872.

Wesley, John. The Imperfection of Human Knowledge. Vol. 6. Third ed. The Works of John Wesley. London: Wesleyan Methodist Bookroom, 1872.

Wesley, John. Journal from Feb 1, 1738 to August 12, 1738. Vol. 1. Third ed. The Works of John Wesley. London: Wesleyan Methodist Bookroom, 1872. 
Wesley, John. Journal from Nov 1, 1739 to September 3, 1741. Vol. 1. Third ed. The Works of John Wesley. London: Wesleyan Methodist Bookroom, 1872.

Wesley, John. Journal from Oct 27, 1743 to Nov 17, 1746. Vol. 1. Third ed. The Works of John Wesley. London: Wesleyan Methodist Bookroom, 1872.

Wesley, John. Justification by Faith. Vol. 5. Third ed. The Works of John Wesley. London: Wesleyan Methodist Bookroom, 1872.

Wesley, John. The Lord Our Righteousness. Vol. 5. Third ed. The Works of John Wesley. London: Wesleyan Methodist Bookroom, 1872.

Wesley, John. The Marks of the New Birth. Vol. 5. Third ed. The Works of John Wesley. London: Wesleyan Methodist Bookroom, 1872.

Wesley, John. The Means of Grace. Vol. 5. Third ed. The Works of John Wesley. London: Wesleyan Methodist Bookroom, 1872.

Wesley, John. The New Birth. Vol. 6. Third ed. The Works of John Wesley. London: Wesleyan Methodist Bookroom, 1872.

Wesley, John. The New Creation. Vol. 6. Third ed. The Works of John Wesley. London: Wesleyan Methodist Bookroom, 1872.

Wesley, John. On a Single Eye. Vol. 7. Third ed. The Works of John Wesley. London: Wesleyan Methodist Bookroom, 1872.

Wesley, John. On Eternity. Vol. 6. Third ed. The Works of John Wesley. London: Wesleyan Methodist Bookroom, 1872.

Wesley, John. On Grieving the Holy Spirit. Vol. 7. Third ed. The Works of John Wesley. London: Wesleyan Methodist Bookroom, 1872.

Wesley, John. On Hell. Vol. 6. Third ed. The Works of John Wesley. London: Wesleyan Methodist Bookroom, 1872.

Wesley, John. On Living Without God. Vol. 7. Third ed. The Works of John Wesley. London: Wesleyan Methodist Bookroom, 1872.

Wesley, John. On Perfection. Vol. 6. Third ed. The Works of John Wesley. London: Wesleyan Methodist Bookroom, 1872.

Wesley, John. On Predestination. Vol. 6. Third ed. The Works of John Wesley. London: Wesleyan Methodist Bookroom, 1872. 
Wesley, John. On Sin in the Believer. Vol. 5. Third ed. The Works of John Wesley. London: Wesleyan Methodist Bookroom, 1872.

Wesley, John. On the Death of Rev. George Whitefield. Vol. 6. Third ed. The Works of John Wesley. London: Wesleyan Methodist Bookroom, 1872.

Wesley, John. On the Fall of Man. Vol. 6. Third ed. The Works of John Wesley. London: Wesleyan Methodist Bookroom, 1872.

Wesley, John. On the Holy Spirit. Vol. 7. Third ed. The Works of John Wesley. London: Wesleyan Methodist Bookroom, 1872.

Wesley, John. On the Omnipresence of God. Vol. 7. Third ed. The Works of John Wesley. London: Wesleyan Methodist Bookroom, 1872.

Wesley, John. On the Temptation. Vol. 6. Third ed. The Works of John Wesley. London: Wesleyan Methodist Bookroom, 1872.

Wesley, John. On the Trinity. Vol. 6. Third ed. The Works of John Wesley. London: Wesleyan Methodist Bookroom, 1872.

Wesley, John. The Privilege of Those Born of God. Vol. 5. Third ed. The Works of John Wesley. London: Wesleyan Methodist Bookroom, 1872.

Wesley, John. The Repentance of Believers. Vol. 5. Third ed. The Works of John Wesley. London: Wesleyan Methodist Bookroom, 1872.

Wesley, John. The Righteousness of Faith. Vol. 5. Third ed. The Works of John Wesley. London: Wesleyan Methodist Bookroom, 1872.

Wesley, John. Salvation by Faith. Vol. 5. Third ed. The Works of John Wesley. London: Wesleyan Methodist Bookroom, 1872.

Wesley, John. Scriptural Christianity. Vol. 5. Third ed. The Works of John Wesley. London: Wesleyan Methodist Bookroom, 1872.

Wesley, John. Sermon CIII: What is Man? Vol. 6. Third ed. The Works of John Wesley. London: Wesleyan Methodist Bookroom, 1872.

Wesley, John. Sermon CIX: What is Man? Vol. 7. Third ed. The Works of John Wesley. London: Wesleyan Methodist Bookroom, 1872.

Wesley, John. The Spirit of Bondage and of Adoption. Vol. 5. Third ed. The Works of John Wesley. London: Wesleyan Methodist Bookroom, 1872. 
Wesley, John. Spiritual Idolatry. Vol. 6. Third ed. The Works of John Wesley. London: Wesleyan Methodist Bookroom, 1872.

Wesley, John. Spiritual Worship. Vol. 6. Third ed. The Works of John Wesley. London: Wesleyan Methodist Bookroom, 1872.

Wesley, John. A Treatise on Baptism. Vol. 10. Third ed. The Works of John Wesley. London: Wesleyan Methodist Bookroom, 1872.

Wesley, John. The Unity of the Divine Being. Vol. 7. Third ed. The Works of John Wesley. London: Wesleyan Methodist Bookroom, 1872.

Wesley, John. Upon Our Lord's Sermon on the Mount: Discourse I. Vol. 5. Third ed. The Works of John Wesley. London: Wesleyan Methodist Bookroom, 1872.

Wesley, John. Upon Our Lord's Sermon on the Mount: Discourse II. Vol. 5. Third ed. The Works of John Wesley. London: Wesleyan Methodist Bookroom, 1872.

Wesley, John. The Way of the Kingdom. Vol. 5. Third ed. The Works of John Wesley. London: Wesleyan Methodist Bookroom, 1872.

Wesley, John. The Way to the Kingdom. Vol. 5. Third ed. The Works of John Wesley. London: Wesleyan Methodist Bookroom, 1872.

Wesley, John. What is Man? Vol. 7. Third ed. The Works of John Wesley. London: Wesleyan Methodist Bookroom, 1872.

Wesley, John. The Witness of Our Own Spirit. Vol. 5. Third ed. The Works of John Wesley. London: Wesleyan Methodist Bookroom, 1872.

Wesley, John. The Witness of the Spirit. Vol. 5. Third ed. The Works of John Wesley. London: Wesleyan Methodist Bookroom, 1872.

Wesley, John. The Works of John Wesley. Vol. 1. Bicentennial ed., Edited by Frank Baker and Albert Cook Outler. Nashville: Arbingdon Press, 1984.

Wesley, John, "The Sermons of John Wesley-Sermon 8: The First Fruits of the Sprit", Wesley Center for Applied Theology http://wesley.nnu.edu/john-wesley/thesermons-of-john-wesley-1872-edition/sermon-8-the-first-fruits-of-the-spirit/ (accessed November 20 2013).

Wesley, John, "The Sermons of John Wesley-Sermon 138: On Grieving the Holy Spirit", Wesley Center for Applied Theology http://wesley.nnu.edu/john-wesley/thesermons-of-john-wesley-1872-edition/sermon-8-on-the-grieving-of-the-holyspirit/ (accessed November 20 2013). 
Wesley, John, "The Sermons of John Wesley-Sermon 141: On the Holy Spirit", Wesley Center for Applied Theology http://wesley.nnu.edu/john-wesley/the-sermons-ofjohn-wesley-1872-edition/sermon-8-on-the-holy-spirit/ (accessed November 20 2013).

Wesley, John. Sermons on Serveral Occasions. Oak Harbor, WA: Logos Research Systems, Inc., 1999.

THE WORKS OF JOHN B. COBB, Jr.

Cobb, John. "Theological Data and Method." The Journal of Religion 33, no. 3 (1953): 212-223.

Cobb, John B. Varieties of Protestantism. Philadelphia: Westminster Press, 1960.

Cobb, John B. Living Options in Protestant theology; A Survey of Methods. Philadelphia: Westminster Press, 1962.

Cobb, John B. The Structure of Christian existence. Philadelphia: Westminster Press, 1967.

Cobb, John B. God and the World. Philadelphia: Westminster Press, 1969.

Cobb, John B. Is It Too Late?: A Theology of Ecology. Beverly Hills, CA: Bruce, 1972.

Cobb, John B. Liberal Christianity at the Crossroads. Philadelphia: Westminster Press, 1973.

Cobb, John B. Christ in a Pluralistic Age. Philadelphia: Westminster Press, 1975.

Cobb, John B. Theology and Pastoral Care. Philadelphia: Fortress Press, 1977.

Cobb, John B. Beyond Dialogue: the Transformation of Christianity and Buddhism. Philadelphia: Fortress Press, 1982.

Cobb, John B. Process Theology as Political Theology. 1st ed. Manchester, Philadelphia: Manchester University Press ;Westminster Press, 1982.

Cobb, John B. Death or Dialogue?: From the Age of Monologue to the Age of Dialogue. Philadelphia; London: Trinity Press International; SCM Press, 1990.

Cobb, John B. Doubting Thomas: Christology in Story Form. New York, NY: Crossroad, 1990. 
Cobb, John B. Can Christ Become Good News Again? St. Louis, MO: Chalice Press, 1991.

Cobb, John B. Matters of Life and Death. 1st ed. Louisville, KY: Westminster/John Knox Press, 1991.

Cobb, John B. Sustainability: Economics, Ecology, and Justice. Maryknoll, NY: Orbis, 1992.

Cobb, John B. Becoming a Thinking Christian. Nashville: Abingdon Press, 1993.

Cobb, John B. Grace and Responsibility: a Wesleyan Theology for Today. Nashville: Abingdon Press, 1995.

Cobb, John B. Reclaiming the Church. 1st ed. Louisville, KY: Westminster J. Knox Press, 1997.

Cobb, John B. The Earthist Challenge to Economism: A Theological Critique of the World Bank [Religion and politics series]. New York, NY: St. Martin's Press, 1999.

Cobb, John B. Postmodernism and Public Policy: Reframing Religion, Culture, Education, Sexuality, Class, Race, Politics, and the Economy. New York: State University of New York Press, 2001.

Cobb, John B. A Christian Natural Theology: Based on the Thought of Alfred North Whitehead. 2nd ed. Louisville: Westminster John Knox Press, 2007.

Cobb, John B. Spiritual Bankruptcy: A Prophetic Call to Action. Nashville, TN: Abingdon Press, 2010.

Cobb, John B. "Email Correspondance." edited by Cory Wetterlin, 2014.

Cobb, John B. Jesus' Abba: The God Who Has Not Failed, 2016.

Cobb, John B. and David Ray Griffin. Process Theology: An Introductory Exposition. Philadelphia: Westminister Press, 1976.

Cobb, John B., Christopher Ives and Masao Abe. The Emptying God: a Buddhist-JewishChristian Conversation. Maryknoll, NY: Orbis Books, 1990.

Cobb, John B., Jr. "Strengthening the Spirit." Union Seminary Quarterly Review 30, no. 2-4 (1975): 130-139.

Cobb, John B., Jr. "Wholeness Centered in Spirit." In Spirit Centered Wholeness Beyond the Psychology of Self, 225-245. Lewiston, NY: Edwin Mellen, 1988. 
Cobb, John B., Jr. "The Revitalization of the Trinity." In Trinity in Process: A Relational Theology of God, edited by Joseph A. Bracken, and Marjorie Suchocki, 1-22: Continuum International Publishing Group, 1997.

Cobb, John B. Jr., Epperly, Bruce G., Nancarrow, Paul S. The Call of the Spirit. Claremont, CA: P\&F Press, 2005.

Cobb, John B., Jr., David J. Lull and Barry A. Woodbridge. "Introduction: Process Thought and New Testament Exegesis." Journal of the American Academy of Religion 47, no. 1 (1979): 21-30.

Cobb, John B. and Paul F. Knitter. Transforming Christianity and the World: A Way Beyond Absolutism and Relativism. Maryknoll, NY: Orbis Books, 1999.

Cobb, John B. and David John Lull. Romans Chalice commentaries for today. St. Louis, MO: Chalice Press, 2005.

Cobb, John B. and Mobilization for the Human Family (Organization). Christian Faith and Religious Diversity. Minneapolis: Fortress Press, 2002.

Cobb, John B. and Jeanyne B. Slettom. The Process Perspective: Frequently Asked Questions about Process Theology. St. Louis, MO: Chalice Press, 2003.

Cobb, John B. and Jeanyne B. Slettom. The Process Perspective II. St Louis, MO: Chalice Press, 2011.

Birch, Charles and John B. Cobb. The Liberation of Life: From the Cell to the Community. Denton, TX: Environmental Ethics Books, 2000.

Griffin, David Ray, John B. Cobb and Clark H. Pinnock, eds. Searching for an Adequate God: a Dialogue Between Process and Free Will Theists. Grand Rapids, MI: W.B. Eerdmans, 2000.

Hartshorne, Charles, John B. Cobb, Franklin I. Gamwell and University of Chicago. Divinity School. Existence and Actuality: Conversations with Charles Hartshorne. Chicago: University of Chicago Press, 1984.

Hough, Joseph C. and John B. Cobb. Christian Identity and Theological Education. Chico, CA: Scholars Press, 1985.

Tracy, David and John B. Cobb. Talking About God: Doing Theology in the Context of Modern Pluralism. New York: Seabury Press, 1983. 


\section{OTHER SOURCES}

A. J. Mason, D.D. Fifty Spiritual Homilies of Marcarius the Egyptian Translations of Christian Literature, Edited by D.D. W. J. Sparrow-Simpson, W. K. Lowther Clarke, B.D. London; NY: Society for Promoting Christian Knowledge, 1921.

Ahn, Jung Sup (Jay). "The Doctrine of Christian Perfection for Today: Reading Wesley's Theology Through the Lens of Process Thought." (Dissertations \& Theses, University of Denver, 2009).

Allison, Gregg R. and Wayne A. Grudem. Historical theology: An Introduction to Christian Doctrine: A Companion to Wayne Grudem's Systematic Theology. Grand Rapids, Mich.: Zondervan, 2011.

Aphraates. "Demonstrations." In Nicene and Post-Nicene Fathers, edited by Philip Schaff and Henry Wace, 13. Buffalo, NY: Christian Literature Publishing Co., 1890.

Aquinas, Thomas, "Sentences" http://www.corpusthomisticum.org/snp1035.html - 2760 (accessed Sept 14 2017).

Aquinas, Thomas, "Summa Theologica" http://www.corpusthomisticum.org/sth4002.html - 46864 (accessed Sept 14 2017).

Aristotle, "Metaphysics", Harvard University Press http://www.perseus.tufts.edu/hopper/text?doc=Perseus\%3Atext\%3A1999.01.0052 \%3Abook\%3D7\%3Asection\%3D1028a (accessed March 30 2015).

Arrington, French L. "The Indwelling, Baptism, and Infilling with the Holy Spirit: a Differentiation of Terms." Pneuma 3, no. 2 (1981): 1-10.

Athanasius, "The Incarnation of the Word" https://www.ccel.org/ccel/schaff/npnf204.vii.ii.xli.html (accessed Oct. 27 2016).

Athanasius. "Four Discources Against the Arians." In Nicene and Post-Nicene Fathers, edited by Philip Schaff and Henry Wace, 4. Buffalo, NY: Christian Literature Publishing Co., 1892.

Athenegoras, "A Plea for the Christians" https://www.ccel.org/ccel/schaff/anf02.v.ii.vi.html (accessed Oct. 27, 2016).

Aufdemberg, Stanley August. "John Harvey Kellogg and Pantheism." (Class Paper, History of the Seventh-day Adventist Church, Andrews University, 1970). 
Augustine. "On the Trinity." In Nicene and Post-Nicene Father, edited by Philip Schaff, 3. Buffalo, NY: Christian Literature Publishing Co., 1887.

Baker, Mary Juno Patton. "Participation in Christ and Eucharist Formation: Building upon John Calvin's Theology of the Lord's Supper In Conversation with Kevin Vanhoozer's Ontonlogy of Divine Communicative Action." (Dissertation, Trinity International University, 2013).

Beardslee, William A. "Whitehead and Hermeneutic." Journal of the American Academy of Religion 47, no. 1 (1979): 31-37.

Becker, Timothy J. "The Holy Spirit in Cyril of Alexandria's 'Dialogues on the Trinity." (Ph.D. diss., Union Theological Seminary, 2012).

Beek, A. van de. "The Spirit of the Body of Christ: The Holy Spirit's Indwelling in the Church." Acta Theologica 33, no. 1 (2013): 252-265.

Benoit, Pierre, Roland E. Murphy and Bastiaan Martinus Franciscus van Iersel. The Presence of God. New York: Paulist Press, 1969.

Bevins, Winfield H. "Historical Development of Wesley's Doctrine of the Spirit." [accessed April 11, 2014].

Bevins, Winfield H. "Historical Development of Wesley's Doctrine of the Spirit." The Pneuma Review (2014).

http://www.pneumafoundation.org/print_article.jsp;jsessionid=4D97BE3E3B21E E8C902490882633CCD3?article=/article_0021.xml\&xslt=article_print.xslt.

Billings, J. Todd. "John Calvin: United to God through Christ." In Partakers of the Divine Nature: The History and Development of Deification in the Christian Traditions, 200-218. Grand Rapids, MI: Baker Academic, 2008.

Bobrinskoy, Boris. "The Indwelling of the Spirit in Christ: 'Pneumatic Christology' in the Cappadocian Fathers." St Vladimir's Theological Quarterly 28, no. 1 (1984): 4965.

Bondi, Roberta C. "The Role of the Holy Spirit from a United Methodist Perspective." Greek Orthodox Theological Review 31, no. 3-4 (1986): 351-360.

Brewer, Brian C. "Evangelical Anglicanism: John Wesley's Dialectical Theology of Baptism." The Evangelical Quarterly 83, no. 2 (2011): 107-132. 
Brierley, Michael W. "Naming a Quiet Revolution: The Panentheistic Turn in Modern Theology." In In Whom We Live and Move and Have Our Being: Panentheistic Reflections on God' Presence in a Scientific World, edited by Philip Clayton and Arthur Peacocke, Ed. Grand Rapids, MI: William B. Eerdmans Publishing Co., 2004.

Brown, Edmund Woodward. Divine Indwelling. Chicago: Fleming H. Revell Company, 1895.

http://search.ebscohost.com.ezproxy.andrews.edu/login.aspx?direct=true \&db=h8h $\& \mathrm{AN}=43454348 \&$ site $=$ ehost live $\& \mathrm{kw}=$ true $\&$ acc $=$ false $\& \mathrm{lpId}=\mathrm{NA} \& \mathrm{ppId}=\mathrm{divp} 3 \& \mathrm{twPV}=$ true $\& \mathrm{xOff}=0 \& \mathrm{yOff}=4$ $19 \& \mathrm{zm}=3 \& \mathrm{fs}=$ null $\&$ rot=0\&docMapOpen=true \&pageMapOpen=true.

Brown, Warren S., Nancey C. Murphy and H. Newton Malony. Whatever Happened to the Soul?: Scientific and Theological Portraits of Human Nature Theology and the Sciences. Minneapolis: Fortress Press, 1998.

Bryan, Lawrence Dow. "The Understanding of Jesus Christ in the Theology of John B. Cobb, Jr.: A Study of the Position of Christology within a Christian Adaptation of Whiteheadian Organismic Philosophy." (Dissertation, Northwestern University, 1973).

Burnett, Joel S. Where is God?: Divine Absence in the Hebrew Bible. Minneapolis: Fortress Press, 2010.

Burns, Basil David. "St. Thomas Aquinas's Philosophy of Love: A Commentary on Mutua Inhaesio (Mutual Indwelling) as the Most Proper Effect of Love in, IA IIAE, QQ 26-28 of the 'Summa Theologiae'." (Ph.D. diss., University of Dallas, 2013).

Burrell, David B. "Indwelling: Presence and Dialogue." Theological Studies 22, no. 1 (1961): 1-17.

Butin, Philip Walker. "Calvin, the Trinity, and the Divine-Human Relationship." (Dissertation, Duke University, 1991).

Campbell, James M. The Indwelling Christ. Chicago: Fleming H. Revell, 1895. $\mathrm{http}: / /$ search.ebscohost.com.ezproxy.andrews.edu/login.aspx?direct=true $\& \mathrm{db}=\mathrm{h} 8 \mathrm{~h}$ $\& \mathrm{AN}=43456040 \&$ site $=$ ehost live $\& \mathrm{kw}=$ true $\&$ acc $=$ false $\& 1 \mathrm{pId}=\mathrm{NA} \& \mathrm{ppId}=\operatorname{divp} 3 \& \mathrm{twPV}=$ true $\& \mathrm{xOff}=0 \& \mathrm{yOff}=0$ $\& z m=$ fit $\&$ fs=null\&rot=0\&docMapOpen=true \&pageMapOpen=true.

Campbell, Ted A. "Back to the Future: Wesleyan Quest for Ancient Roots: The 1980's." Wesleyan Theological Journal 32, no. 1 (1997): 5-16. 
Canale, Fernando Luis. Revelation and inspiration: The Classical Model. Berrien Springs, MI: Andrews University, 1994.

Canale, Fernando Luis. "Deconstructing Evangelical Theology?" Andrews University Seminary Studies 44, no. 1 (2006): 95-130.

Cannon, William Ragsdale. The Theology of John Wesley, with Special Reference to the Doctrine of Justification. New York, Nashville,: Abingdon-Cokesbury Press, 1946.

Caraway, James E. God as Dynamic Actuality: A Preliminary Study of the Process Theologies of John B. Cobb, Jr. and Schubert M. Ogden. Washington, D.C.: University Press of America, 1978.

Carr, Anne E. "Providence, Power and the Holy Spirit." Horizons 29, no. 1 (2002): 8093.

Carter, Charles W., R. Duane Thompson and Charles R. Wilson. A Contemporary Wesleyan Theology: Biblical, Systematic, and Practical. Grand Rapids, MI: Zondervan Pub. House, 1983.

Chin, Clive S. "Unio Mystica and Imitatio Christi: The Two-Dimensional nature of John Calvin's Spirituality." (Dissertation, Dallas Theological Seminary, 2002).

Collins, Kenneth J. John Wesley's Theology of Law, 1984.

Collins, Kenneth J. The Scripture Way of Salvation: The Heart of John Wesley's Theology. Nashville: Abingdon Press, 1997.

Collins, Kenneth J. John Wesley: A Theological Journey. Nashville, TN: Abingdon Press, 2003.

Collins, Kenneth J. The Theology of John Wesley: Holy Love and the Shape of Grace. Nashville, TN: Abingdon Press, 2007.

Congar, Yves M.-J. Cardinal. "Church, Kingdom, and the Eschatological Temple." In Temple and contemplation: God's presence in the cosmos, church, and human heart, Letter \& Spirit : a journal of Catholic biblical theology, Vol. 4, 289-317. Steubenville, OH: St. Paul Center for Biblical Theology, 2008.

Cooper, John W. Body, Soul, and life Everlasting: Biblical Anthropology and the Monism-Dualism Debate. Grand Rapids, MI: Eerdmans, 1989.

Cooper, John W. Panentheism, The Other God of the Philosophers: From Plato to the Present. Grand Rapids, MI: Baker Academic, 2006. 
Cunningham, Francis L. B. The Indwelling of the Trinity; A Historico-Doctrinal Study of the Theory of St. Thomas Aquinas. Dubuque: Priory Press, 1955.

Daniels, A. G., How the Denomination Was Saved from Pantheism, March 12, 1935, Andrews University Center for Adventist Research, Berrien Springs, MI.

Davidson, Jo Ann. "A Power or Person: The Nature of the Holy Spirit." JATS 27, no. 1 (2016): 24-36.

Davidson, Richard M. "Interpreting Scripture: an Hermeneutical "Decalogue"." Journal of the Adventist Theological Society 4, no. 2 (1993): 95-114.

Davison, Richard. "The Nature of the Human Being from the Beginning: Genesis 1-11." In "What Are Humans Beings That You Remember Them?" Proceedings of the Third International Bible Conference, Nof Ginosar and Jerusalem, June 11-21, 2012, edited by Clinton Wahlen, 1-34. Silver Spring, MD: Review and Herald, 2015.

Donnelly, Malachi J. "The Indwelling of the Holy Spirit According to M. J. Scheeben." Theological Studies 7, no. 2 (1946): 244-280.

Donnelly, Malachi J. "The Inhabitation of the Holy Spirit: A Solution According to De La Taille." Theological Studies 8, no. 3 (1947): 445-470.

Dunn, James D. G. Romans 1-8. Vol. 38A Word Biblical Commentary. Dallas, TX: Word Incorporated, 1988.

Engelbrecht, Ben. "The Indwelling of the Holy Spirit, Pt 1: An Evaluation of Contemporary Pneumatology." Journal of Theology for Southern Africa, no. 30 (1980): 19-33.

Evans, William Borden. "Imputation and Impartation: The Problem of Union with Christ in Nineteenth-Century American Reformed Theology." (Dissertation, Vanderbilt University, 1996).

Fagg, Lawrence W. "Sacred Indwelling and the Electromagnetic Undercurrent in Nature: A Physicist's Perspective." Zygon 37, no. 2 (2002): 473-490.

Fee, Gordon D. God's Empowering Presence: the Holy Spirit in the Letters of Paul. Peabody, MA: Hendrickson Publishers, 1994.

Felleman, Laura Bartels. "The Evidence of Things Not Seen: John Wesley's Use of Natural Philosophy." (Dissertation/Thesis, Drew University, 2004).

Fitzmyer, Joseph A. S.J. Romans: A New Translation with Introduction and Commentary. Vol. 33 Anchor Yale Bible New Haven; London: Yale University Press, 2008. 
Froget, Barthelemy. The Indwelling of the Holy Spirit in the Souls of the Just: According to the Teaching of St. Thomas Aquinas. Translated by M.A. Rev. Sydney A. Raemers. Translated from the 3rd French ed. Forgotten Books. Westminster, MD: The Newman Press, 1952.

Gerson, Lloyd, "Plotinus", The Stanford Encyclopedia of Philosophy <http://plato.stanford.edu/archives/sum2014/entries/plotinus/> (accessed March 31 2015).

Gifford, James D. Jr. "Union with Christ: A Third Type of Perichoresis." (Ph.D. diss., Southeastern Baptist Theological Seminary, 2010).

Gleason, Robert W. The indwelling Spirit. Staten Island, NY: Alba House, 1966.

Godsey, John D. "The Interpretation of Romans in the History of the Christian Faith." Interpretation 34, no. 1 (1980): 3-16.

Gorman, Frank H. Divine Presence and Community: a Commentary on the Book of Leviticus International theological commentary. Grand Rapids, Mich. Edinburgh: Wm. B. Eerdmans; Handsel Press, 1997.

Grabowski, Stanislaus J. "The Holy Ghost in the Mystical Body of Christ According to St. Augustine." Theological Studies 5, no. 4 (1944): 453-483.

Grabowski, Stanislaus J. "St. Augustine and the Presence of God." Theological Studies 13, no. 1 (1952): 336-358.

Gregersen, Niels Henrik. "Three Varieties of Panentheism." In In Whom We Live and Move and Have Our Being: Panentheistic Reflections on God'Presence in a Scientific World, edited by Philip Clayton and Arthur Peacocke, 19-35. Grand Rapids, MI: William B. Eerdmans Publishing Co., 2004.

Grenz, Stanley J. The Named God and the Question of Being: a Trinitarian TheoOntology. 1st ed. Matrix of Christian theology., Edited by Stanley J. Grenz. Louisville, Ky.: Westminster John Knox Press, 2005.

Griffin, David Ray. "John B. Cobb, Jr.: A Theological Biography." In Theology and the university: essays in honor of John B. Cobb, Jr, edited by David Ray Griffin, 225242. Albany, NY: State University of New York Press, 1991.

Griffin, David Ray. "Panentheism: A Postmodern Revelation." In In Whom We Live and Move and Have Our Being: Panentheistic Reflections on God' Presence in a Scientific World, edited by Philip Clayton and Arthur Peacocke, 36-47. Grand Rapids, MI: William B. Eerdmans Publishing Co., 2004. 
Griffin, David Ray and Thomas J. J. Altizer. John Cobb's Theology in Process. Philadelphia: Westminster Press, 1977.

Gulley, Norman R. Systematic Theology: Prolegomena. Berrien Springs, MI: Andrews University Press, 2003.

Gurland-Blaker, Avram. "Ethical Life and Ontology in Hegel's 'Phenomenology of Spirit'." (Ph.D. diss., Temple University, 2013).

Hamilton, James Merrill, Jr. "He is With You and He Will be in You: The Spirit, the Believer, and the Glorification of Jesus." (Ph.D. diss., The Southern Baptist Theological Seminary, 2003).

Hartshorne, Charles. "Panpsychism." In A History of Philosophical Systems, edited by Vergilius Ferm, 442-53. New York: The Philosophical Library, 1950.

Hartshorne, Charles. Reality as Social Process; Studies in Metaphysics and Religion. New York: Hafner Pub. Co., 1971.

Herrman, Timothy P. "A Capacity for the Divine: An Ontological Perspective on the Human Soul in Augustine's 'Confessions'." (Ph.D. diss., University of Dallas, 2006).

Hiebert, Paul G. and ebrary Inc. The Missiological Implications of Epistemological Shifts Affirming Truth in a Modern/Postmodern World. Harrisburg, PA: Trinity Press International, 1999.

Hoyt, Edge. A Constructive Postmodern Perspective on Self and Community: From Atomism to Holism. Lewiston: E. Mellen Press, 1994.

Im, Seung-An. "John Wesley's Theological Anthropology: A Dialectic Tension Between the Latin Western Patristic Tradition (Augustine) and the Greek Eastern Patristic Tradition (Gregory of Nyssa)." (Dissertation, Drew University, 1994).

James D. Gifford, Jr. "Union with Christ: A Third Type of Perichoresis." (Dissertation, Southeastern Baptist Theological Seminary, 2010).

Johnson, Alan Julius. "Shekinah: The Indwelling of God in the Theology of Juergen Moltmann." (Ph.D. diss., Luther Seminary, 2003).

Kao, Chin-Tien. "The Particularity and Universlity of the Incarnation: A Study of the Process Christologies of W. Norman Pittenger and John B. Cobb, Jr." (Dissertation, Drew University, 1984).

Kasemann, Earnest. Commentary on Romans. Translated by Geoffrey W. Bromiley. Grand Rapids, MI: William B. Eerdmans Publishing Company, 1980. 
Keener, Craig S. The Mind of the Spirit : Paul's Approach to Transformed Thinking. Grand Rapids, MI: Baker Academic, 2016.

Kellogg, John Harvey. The Living Temple. Battle Creek, MI: Good Health Publishing Co., 1903.

Kim, Young Taek. "John Wesley's Anthropology: Restoration of the Imago Dei as a Framework for Wesley's Theology." (Dissertation, Drew University, 2006).

Kittel, G., Bromiley, G. W., \& Friedrich, G. Ed., Theological Dictionary of the New Testament. Grand Rapids, MI:Eerdmans, 1964.

Konsmo, Erik M. "How the Pauline Spirit-Metaphors Express the Intangible Spirit's Tangible Presence in the Life of the Christian." (Ph.D. diss., Fuller Theological Seminary, School of Theology, 2008).

Kupp, David D. Matthew's Emmanuel: Divine Presence and God's People in the First Gospel. Cambridge; New York: Cambridge University Press, 1996.

Lauer, Quentin. Hegel's Concept of God. Albany: State University of New York Press, 1982.

Lee, Hoo-Jung. "The Doctrine of New Creation in the Theology of John Wesley." (Ph.D., Emory University, 1991).

Lee, Hoo-Jung. "Experiencing the Spirit in Wesley and Marcarius." In Rethinking Wesley's theology for contemporary Methodism, edited by Randy L. Maddox and Theodore Runyon, 256. Nashville, TN: Kingswood Books, 1998.

Letter, Prudence de. "Sanctifying Grace and the Divine Indwelling." Theological Studies 14, no. 2 (1953): 242-272.

Levering, Matthew. Engaging the Doctrine of the Holy Spirit: Love and Gift in the Trinity and the Church. Grand Rapids, MI: Baker Academic, 2016.

Levison, Jack. Inspired: the Holy Spirit and the Mind of Faith. Grand Rapids, MI: William B. Eerdmans Publishing Company, 2013.

Lewis, Gordon R. and Bruce A. Demarest. Integrative Theology. Vol. 2. Grand Rapids, MI: Zondervan, 1996.

Linman, Jonathan. "Martin Luther: 'Little Christs for the World'; Faith and Sacraments as Means to Theosis." In Partakers of the divine nature: the history and development of deification in the Christian traditions, 189-199. Grand Rapids, MI: Baker Academic, 2008. 
Lloyd-Jones, D. M. Romans: And Exposition of Chapter 6 The New Man. London: The Banner of Truth Trust, 1972.

Lodahl, Michael E. God of Nature and of Grace: Reading the World in a Wesleyan Way. Nashville: Kingswood, 2004.

Longenecker, Richard N. The Epistle to the Romans: A Commentary on the Greek Text The New International Greek Testament Commentary. Grand Rapids, MI: Eerdmans, 2016.

Loyer, Kenneth. God's Love Through the Spirit: the Holy Spirit in Thomas Aquinas \& John Wesley. Washington, D.C.: The Catholic University of America Press, 2014.

Loyer, Kenneth Milton. ""And to Crown All": John Wesley on Union with God in the New Creation." Methodist Review 1, (2009): 109-125.

Lull, David J. "The Spirit and the Creative Transformation of Human Existence." Journal of the American Academy of Religion 47, no. 1 (1979): 39-55.

MacArthur, John. Romans 1-8 MacArthur New Testament commentary., Edited by John MacArthur. Chicago: Moody Press, 1991.

Maddox, Randy L. "John Wesley and Eastern Orthodoxy: Influences, Convergences and Differences." The Asbury Journal 45, no. 2 (1990): 29-53.

Maddox, Randy L. Responsible Grace: John Wesley's Practical Theology. Nashville, TN: Kingswood Books, 1994.

Martyr, Justin, "The Second Apology" https://www.ccel.org/ccel/schaff/anf01.viii.iii.x.html (accessed Oct. 27. 2016).

McPartlan, Paul. Sacrament of Salvation: An Introduction to Eucharistic Ecclesiology. Edinburgh: T \& T Clark, 1995.

Meacham, Katharine Rothrock. "Creative Transformation Happens and Christ is its Image: A Critical Analysis of the Process Christology of John B. Cobb, Jr." (Dissertation, Temple University, 1994).

Mitchell, Nathan. "Christ's Presence in the Assembly." Worship 80, no. 3 (2006): 252265.

Mitchell, Nathan. "Present in the Sacraments." Worship 80, no. 4 (2006): 347-360.

Mitchell, Nathan. "Real Presence." Worship 80, no. 6 (2006): 551-566.

Mitchell, Nathan. "Revisiting Presence." Worship 80, no. 1 (2006): 55-68. 
Moe-Lobeda, Cynthia Diane. "Journey Between Worlds: Economic Globalization, and Luther's Indwelling God as Subversive Moral Agency." (Dissertation, Union Theological Seminary, 2001).

Moo, Douglas J. Romans 1-8 The Wycliffe exegetical commentary. Chicago: Moody Press, 1991.

Moore, Marvin. "Romans 8:26,27 Says that the Holy Spirit Intercedes for Us, and Verse 34 Says Jesus is at God's Right Hand Interceding for Us. What Exactly Takes Place in this Intersession?" Dialogue., (2004).

Moser, Maureen Beyer. "Teacher of Holiness: The Holy Spirit in Origen's 'Commentary on the Epistle to the Romans'." (Ph.D. diss., Duquesne University, 2004).

Muller, Richard A. "Calvin on Sacramental Presence, In the Shadow of Marburg and Zurich." Lutheran Quarterly 23, no. 2 (2009): 147-167.

Nash, Ronald H. "Process Theology and Classical Theism." In Process theology, 8-12. Grand Rapids, MI: Baker Book House, 1987.

Nidoy, Raul Antonio A. "The Holy Spirit in the Church and in Souls. A HistoricoAnalogical Study of the Two Indwellings." (Extracto de la Tesis Doctoral presentada en la Facultad de Teología de la Universidad de Navarra, UNIVERSIDAD DE NAVARRA, 2001).

Noll, Mark A. "John Wesley and the Doctrine of Assurance." Bibliotheca Sacra 132, no. 526 (1975): 161-177.

Novation. "Treatise Concerning the Trinity." In Ante-Nicene Fathers, edited by James Donaldson Alexander Roberts, and A. Cleveland Coxe, 5. Buffalo, NY: Christian Literature Publishing Co., 1886.

Oden, Thomas C. John Wesley's Teachings. Vol. 1. Grand Rapids, MI: Zondervan, 2012.

Oden, Thomas C. John Wesley's Teachings: God and Providence. Vol. 1. 3 vols. Grand Rapids, MI: Zondervan, 2012.

Olson, Roger E. The Story of Christian Theology: Twenty Centuries of Tradition \& Reform. Downers Grove, IL: InterVarsity Press, 1999.

Olson, Roger E. The Journey of Modern Theology: From Reconstruction to Deconstruction. Downers Grove, IL: IVP Academic, 2013.

Outler, Albert Cook. "A Focus on the Holy Spirit: Spirit and Spirituality in John Wesley." Quarterly Review 8, no. 2 (1988): 3-18. 
Pattison, George. God and Being: An Enquiry. Oxford, New York: Oxford University Press, 2011.

Peacocke, Philip Clayton and Arthur, Ed. In Whom We Live and Move and Have Our Being: Panentheistic Reflections on God' Presence in a Scientific World. Grand Rapids, MI: William B. Eerdmans Publishing Co., 2004.

Peckham, John C. "The Analogy of Scripture Revisited: A Final Form Canonical Approach to Systematic Theology." Mid-America Journal of Theology 22, (2011): 41-53.

Peckham, John C. "The Concept of Divine Love in the Context of the God-World Relationship." (Dissertation, Andrews University Seventh-day Adventist Theological Seminary, 2012).

Pidgeon, George Campbell. The Indwelling Christ. New York: Oxford University Press, 1949.

Pittack, Richard Bruce. "The Pantheistic Crisis In S.D.A. History." (Class Paper for CH570-2 History of SDA Church, Center for Adventist Research, Andrews University, June 1972).

Pittack, Richard Bruce, Pantheism, Denomination Saved From, by Arthur G. Daniells, March 12, 1935, Stenographically Recoarded Statement.

Plato. "Philebus." In The Dialogues of Plato, edited by Robert Maynard Hutchins, 7, 609639. Chicago: Encyclopaedia Britanica, 1952.

Plato. "Timaeus." In The Dialogues of Plato, edited by Robert Maynard Hutchins, 7, 442477. Chicago: Encyclopaedia Britanica, 1952.

Plato. Plato's Republic. http://www.gutenberg.org/files/1497/1497-h/1497-h.htm: Gutenberb EBook, 2008. (accessed March 24, 2015).

Quinn, Russell Dale. "Expectation and Fulfillment of the Gift of the Holy Spirit in the Gospel of John." (Ph.D. diss., The Southern Baptist Theological Seminary, 2010).

Randall, Rory R. "Towards an Open Theist Renewal Theology." Regent University, 2015).

Rice, Richard. The Openness of God: The Relationship of Divine Foreknowledge and Human Free Will. Nashville, TN: Review and Herald Pub. Association, 1980.

Ruskjer, Jacquelyn E. "Pantheism in Kellogg's The Living Temple: Fact or Fable?" (Class Paper, HIST/RELH 585, Loma Linda University, 1985). 
Savran, George W. Encountering the Divine: Theophany in Biblical Narrative. London: T \& T Clark International, 2005.

Schreiner, Thomas R. Romans. Vol. 6 Baker Exegetical Commentary on the New Testament. Grand Rapids, MI: Baker Books, 1998.

Shrier, Paul and Cahleen Shrier. "Wesley's Sanctification Narrative: A Tool for Understanding the Holy Spirit's Work in a More Physical Soul." Pneuma 31, no. 2 (2009): 225-241.

Skrbina, David. Panpsychism in the West. Cambridge: The MIT Press, 2005.

Sprague, Stuart Russell. "Shaping a Process Theology: The Theological Method of John B. Cobb, Jr." (Dissertation, The Southern Baptist Theological Seminary, 1975).

Starkey, Lycurgus Monroe, Jr. "The Work of the Holy Spirit in the Theology of John Wesley." (Dissertation, Columbia University, 1953).

Stefan, Crinisor. "The Role of the Holy Spirit in the Life of Discipleship: A Study in the Fourth Gospel's Narrative." (Ph.D. diss., Fuller Theological Seminary, School of Theology, 2003).

Stephanou, Eusebius A. "Divine Indwelling in the World." Greek Orthodox Theological Review 4, no. 2 (1959): 135-150.

Stone, Bryan P. "The Spirit and the Holy Life." Quarterly Review 21, no. 2 (2001): 156168.

Stott, John R. W. Romans: God's Good News for the World. Downers Grove, IL: InterVarsity Press, 1994.

Suchocki, Marjorie. "John Cobb's Trinity: Implications for the University." In Theology and the university: essays in honor of John B. Cobb, Jr, edited by David Ray Griffin, 148-165. Albany, NY: State University of New York Press, 1991.

Swope, John D. "Toward a Spirit-to-Spirit Model of Christian Union with God: Exploring the Anthropological Dimension in Biblical and Theological Perspectives." (Ph.D. diss., Trinity International University, 2010).

Thiselton, Anthony C. The Holy Spirit-- in Biblical Teaching, Through the Centuries, and Today. Grand Rapids, MI: Eerdmans, 2013.

van de Beek, A. "The Spirit of the Body of Christ: The Holy Spirit's Indwelling in the Church." Acta Theologica 33, no. 1 (2013): 252-265. 
Vickers, Jason E. "The Making of a Trinitarian Theologian: the Holy Spirit in Charles Wesley's Sermons." Pneuma 31, no. 2 (2009): 213-224.

Waltke, B. K. , Theological Wordbook of the Old Testament. Chicago:Moody Press, 1999.

Whidden, Woodrow W. The Judgment and Assurance: The Dynamics of Personal Salvation. Hagerstown, MD: Review and Herald Pub. Association, 2012.

White, Ellen G. Testimonies for the Church. Vol. 8. 1-9 vols. Battle Creek, MI: Steam Press of the Review \& Herald Office, 1904.

Whitehead, Alfred North. Process and Reality, An Essay in Cosmology; Gifford Lectures Delivered in the University of Edinburgh Euring the Session 1927-28. New York, Cambridge, Eng.,: The Macmillan Company; University Press, 1929.

Whyte, Lancelot Law. Essay on Atomism, from Democritus to 1960. [1st ] ed. Middletown, CT: Wesleyan University Press, 1961.

Wilson, Brian C. Dr. John Harvey Kellogg and the Religion of Biologic Living. Bloomington, IN: Indiana University Press, 2014.

Wilson, Ian. Out of the Midst of the Fire: Divine Presence in Deuteronomy. Atlanta: Scholars Press, 1995.

Youn, Chul Ho. "God's Relation to the World and Human Existence in the Theologies of Paul Tillich and John B. Cobb, Jr." (Dissertation, Northwestern University, 1990). 
